\title{
Patient, gezondheidszorg en langdurige ziekte : een onderzoek onder 213 langdurig zieke werknemers in Z.-Limburg
}

Citation for published version (APA):

Soeters, J. M. L. M. (1983). Patient, gezondheidszorg en langdurige ziekte : een onderzoek onder 213 langdurig zieke werknemers in Z.-Limburg. [Doctoral Thesis, Maastricht University]. Rijksuniversiteit Limburg. https://doi.org/10.26481/dis.19831209js

Document status and date:

Published: 01/01/1983

DOI:

10.26481/dis.19831209js

Document Version:

Publisher's PDF, also known as Version of record

Please check the document version of this publication:

- A submitted manuscript is the version of the article upon submission and before peer-review. There can be important differences between the submitted version and the official published version of record.

People interested in the research are advised to contact the author for the final version of the publication, or visit the DOI to the publisher's website.

- The final author version and the galley proof are versions of the publication after peer review.

- The final published version features the final layout of the paper including the volume, issue and page numbers.

Link to publication

\footnotetext{
General rights rights.

- You may freely distribute the URL identifying the publication in the public portal. please follow below link for the End User Agreement:

www.umlib.nl/taverne-license

Take down policy

If you believe that this document breaches copyright please contact us at:

repository@maastrichtuniversity.nl

providing details and we will investigate your claim.
}

Copyright and moral rights for the publications made accessible in the public portal are retained by the authors and/or other copyright owners and it is a condition of accessing publications that users recognise and abide by the legal requirements associated with these

- Users may download and print one copy of any publication from the public portal for the purpose of private study or research.

- You may not further distribute the material or use it for any profit-making activity or commercial gain

If the publication is distributed under the terms of Article 25fa of the Dutch Copyright Act, indicated by the "Taverne" license above, 
PATIENT, GEZONDHEIDSZORG EN LANGDURIGE ZIEKTE

Een onderzoek onder 213 langdurig zieke werknemers in $z$-Limburg.

$P R O E F S C H R I F T$

ter verkrijging van de graad van doctor in de sociale wetenschappen aan de Rijksuniversiteit Limburg te Maastricht op gezag van de Rector Magnificus Prof.Dr. H.C. Hemker, volgens besluit van het College der Dekanen in het openbaar te verdedigen op vrijdag 9 december 1983, des namiddags om vier uur precies, in de aula van de universiteit.

door

Joseph Mathieu Lambert Marie Soeters geboren te Maastricht in 1954. 
Promotor : Prof.dr. H. Philipsen

Referenten: Prof.dr. Tj. de Boorder Dr. A. Dijkstra 
Het in dit proefschrift verslagen onderzoek is uitgevoerd in opdracht van het Provinciale Bestuur Limburg en met subsidies van de Ministeries van Sociale Zaken en Werkgelegenheid en van Economische Zaken (Perspectieven-Nota-Limburg-gelden).

Een eerdere publicatie van dit onderzoek verscheen onder de titel "Na de ziekmelding ...." en correspondeert met de hoofdstukken 3,4 en 5 van dit proefschrift.

De werkzaamheden voor de genoemde publicatie zijn verricht onder begeleiding van een commissie, waarvan de samenstelling in bijlage $I$ staat vermeld. 
Tekstverwerking: M. Arkenbout

Omslag

: G. van Wunnik

Druk

: B. Meerstad 
DANKWOORD

HOOF DSTUK:

1. INLEIDING 1 .

1. 1. De voorgeschiedenis van het onderzoek. 1.

1.2. Probleemstelling en reikweidte van het onderzoek in het kort.

1.3. Relevantie van het onderzoek.

1.4. Opbouw van dit verslag.

2. LANGE ZIEKTEDUREN EN WACHTTIJDEN: EEN LITERA TUUROVERZICHT.

2.2. Langdurig ziekteverzuim.

2.3. De organisatie van de gezondheidszorg en het wachttijdenprobleem.

2.4. Uitstelgedrag.

2.5. Het doorverwijzen.

2.6. Samenvatting.

3.2. De omschrijuing van de onderzoekspopulatie.

3.3. Uitvoering van het onderzoek.

3.5. Enkele kenmerken van de respondenten. 
4. 1. Inleiding

4.2. De patiënten en het begin van hun ziekte.

4.3. De contacten met de gezondheidszorg.

4.4. Inhoudelijke aspecten van de contacten met de gezondheidszorg.

50 .

4.5. De wachttijden.

4.6. De wachttijden geconfronteerd met het aambod van gezondheidszorgvoorzieningen.

4.7. Samenvatting.

5. 1. Inleiding.

70 .

5.2. Werkhervatting of arbeldsongeschikt?

5.3. Onderhandelingen over aanpassingen in het werk.

5.4. Het subjectief herstel.

5.5. Samenvatting.

6.1. Inleiding.

85.

6.2. De te verklaren variabelen.

86.

6.3. De verklarende variabelen.

91.

6. 4. De ondexlinge samenhangen dex variabelen.

98.

6.5. Samenvatting.

7. DE VERKLARING VAN DE VERSCHILLEN IN HET VERWI J SCI JFER, VERWI JZ INGSWACHTDAGEN EN STUURLOZE PERIODEN.

7.2. Theoretische overwegingen bij de regressie-analyse.

7.3. Het verwijscijfer.

7.4. Verwijzingswachtdagen.

7.5. De stuurloze periode(n).

7.6. Samenvatting. 
8. DE VERKLARING VAN DE VERSCHILLEN IN ZIEKTEDUUR.

8.1. Inleiding.

131.

8.2. De multiple regressie-analyse.

8.3. De aanvullende partiële correlatie141.

8.4. Samenvatting.

9. SAMENVATTING EN BESPREKING VAN DE RESULTATEN.

9.1. Samenvatting in grote lijnen. 147.

9.2. Beperkingen van het onderzoek; voorstellen voor verder onderzoek.

9.3. Beleidsoverweglingen naar aanleiding van het onderzoek.

BI JLAGEN

CURRICULUM VITAE 
$A B P$ Algemeen Burgerlijk Pensioenfonds.

AKER Afdelingskas / Eigen-risico-drager in verband met de ziektewet.

BV Bedrijfswereniging.

CCOZ stichting Coördinatie van communicatie met betrekking tot gegevens voor onderzoek inzake ziekteverzuim.

GAK Gemeenschappelijk Administratiekantoor.

GMD Gemeenschappelijk Medische Dienst.

I.P. Invaliditeitspensioen.

KNMG Koninklijke Nederlandse Maatschappij ter bevordering van de Geneeskunde.

SER Sociaal Economische Raad.

VUT Vervroegde Uittredingsregeling.

WAGW Wet Aangepaste Arbeid Gehandicapte Werknemers.

WAO Wet op de Arbeidsongeschiktheidsverzekering.

ZFW Ziekenfondswet.

ZW ziektewet.

HA Huisarts.

$B A$ Bedrijfsarts.

VG Verzekeringsgeneeskundige. 
In de allereerste plaats wil ik prof.dr. H. Philipsen bedanken. Hij bood mij de gelegenheid, om enkele jaren onderzoek te doen en hij heeft $\mathrm{mij}$ in die periode begeleid, tot en met de voltooiing van dit proefschrift. Bovendien bekommerde hij zich om hetgeen na het project zou gebeuren. Een dergelijke betrokkenheid zal vermoedelijk niet elke promovendus ten deel vallen.

Voorts ben ik dank verschuldigd aan de beide referenten voor hun vriendelijke en behulpzame wijze van refereren. Prof.dr. Tj. de Boorder dank ik speciaal voor zijn aanwijzingen op (arbeids-)geneeskundig terrein, alsmede voor het feit, dat hij mij attent maakte op diverse elgenaardigheden in mijn taalgebruik. Dr. A. Dijkstra dank ik met name voor zijn precies commentaar ten aanzien van methodologische kwesties en ordeningsvraagstukken.

Met "collega proximus" Cees schröer en met Frans Nijhuis heb ik het driemanschap gevormd, dat het z-Limburgs ziekteverzuimproject heeft uitgevoerd. Deze samenwerking is altijd zeer plezierig en tot wederzijdse stimulans verlopen; als het aan mij ligt, komt aan die samenwerking geen einde. Het veld- en codeerwerk voor het onderzoek is uitgevoerd door Vonca Schaffers, Joke Stikkelbroek-Henrar en Paul Wolf. Door hun contacten met de patiënten hebben zij bovendien belangrijke bijdragen geleverd aan de ontwikkeling van vragenlijsten en codeersystemen. Vonca Schaffers heeft bovendien haar jarenlange ervaring met patiënten en hun carrières ingebracht bij de bepaling van behandelings-"lijnen" en wachttijden. Zonder de activiteiten van deze drie "assistenten" zou dit onderzoek echt nooit tot stand gekomen zijn!

Drs. Th. v.d. Klaauw van het NIPG/TNO te Leiden heeft geheel belangeloos informatie verstrekt over de opzet en uitvoering van het voor deze studie zo belangrijke "Tordoir"-onderzoek. Henk Lebens bood altijd razendsnel de helpende hand, wanneer iets voor de eerste of zoveelste keer uit de computer gehaald moest worden. Piet zinken heeft de progranuatuur gemaakt voor de berekeningen, die buiten het voor sociologen vertrouwde SPSS-terrein vallen. 
Marjoke Arkenbout van de capaciteitsgroep Medische socilologie heeft de tekstverwerking van de eerste tot en met de laatste fase in handen gehad. Dit deed zij altijd precies, snel, rustig en goed gehumeurd; iets wat ik -zeker aan het stresserende einde van de rit- een knappe en bovendien prettige prestatie heb gevonden.

Verder wil ik nog een aantal mensen bedanken voor kleinere klusjes, die niettemin op dat moment erg belangrijk waren. Drs. V. Dubois van de capaciteitsgroep Huisartsgeneeskunde voor zijn "diagnostiserende hulp". Marga Doyle voor het maken van de Engelse samenvatting. Gerry van Wunnik voor het maken van de omslag en de grafleken. Sylvia Nelk voor het inspringen bij de type-werkzaamheden, toen het anders echt niet kon. Tom van Veen en Rendel de Jong voor het belangeloos beschikbaar stellen van een stelling. En Guus van Rooij -tenslotte- voor de illustratie.

De manier waxop men werkt is sterk afhankelijk van de afdeling waarin dat werk gebeurt. In mijn geval was dat de afgelopen jaxen de capaciteitsgroep Medische Sociologie; het werk in deze groep heb ik altijd als prettig ondervonden en bij deze wil ik mijn collega"s bedanken voor de collegiale sfeer, waarin de werkzaamheden doorgaans plaatsvinden.

Mijn nieuwe collega"s van de studierichting Economie wil ik bedanken voor het feit, dat ik de tijd heb kunnen nemen, die ik redelijkerwijze nodig achtte voor de afronding van dit proefschrift.

Tenslotte: promoveren is elgenlijk echt afstuderen. Bij deze afronding van de studie wil ik mijn ouders bedanken voor de mogelijkheid en stimulans tot studeren, die zijn mij altija geboden hebben.

En helemaal aan het einde wil ik mijn persoonlijke "raadsvrouw" Vivian bedanken, voor al haar goede adviezen en ondersteuning, al dan niet rechtstreeks in verband met dit werkstuk.

sjo soeters. 


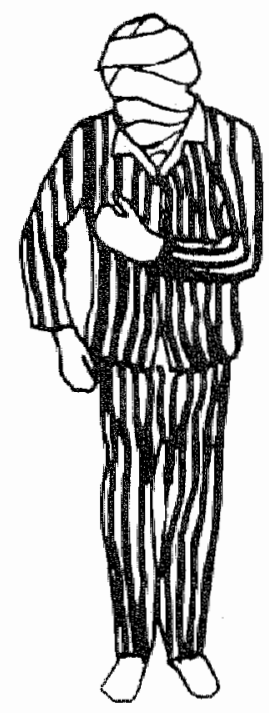



HOOFDSTUK 1.

INLEIDING.

1.1. De voorgeschiedenis van het onderzoek

Vooral sinds de Tweede Wereldoorlog hebben mensen ziekteverzuim bestudeerd. Het werk van Mayo c.s. (1945) in Amerika tijdens de oorlogsperiode markeert het begin van een onderzoekstraditie, die met name ook in Nedexland een grote bloei heeft beleefd. Zowel overheid als bedrijfsleven hebben in Nederland aan het ziekteverzuimprobleem ruime aandacht en onderzoeksmogelijkheden geschonken. Het economisch belang van het ziekteverzuimprobleem is hier ongetwijfeld niet vreemd aan.

In het van oudsher sterk geIndustrialiseerde $z$-Limburg heeft het ziekteverzuim sinds die tijd ook bij diverse groeperingen in de belangsteliing gestaan. Daarvan getuigen niet alleen steeds weer terugkerende krantenberichten over dit thema, maar ook enkele meer officiële gebeurtenissen. Zo werd reeds in 1949 een commissle opgericht ter bestudering van het ziekteverzuim in de Limburgse mijnondernemingen (Crousen, 1968). In de zestiger jaren riep een werkgroep, onder auspiciën van de Maastrichtse Kamer van Koophandel, de hulp in van onderzoekers van de Katholieke Universiteit in Nijmegen; men had daarmee de bedoeling, om meer inzicht te krijgen in het ziekteverzuim van een aantal Maastrichtse bedrijven. Het niet officieel gepubliceerde verslag van van Hoof en Nas (1969) vormt de neerslag van deze activiteiten. In de zeventiger jaren, toen $z$-Limburg vanwege de ongunstige economische situatie tot Herstructureringsgebied was bestempeld, kreeg het ziekteverzuim hernieuwde belangstelling; dit keer van de kant van de overheid. In de perspectievennota z-Limburg (1978) werd namelijk met enige zorg gesignaleerd, dat het ziekteverzuim in deze regio hoger was dan elders in Nederland en het omringende buitenland. Dit zou een nadelige invloed kunnen hebben op het imago van $z$-Limburg als investerings- en vestigingsgebied. Om deze reden heeft de Provinciale overheid aan de dan inmiddels opgerichte Rijksuniversiteit Limburg het verzoek gedaan, om onderzoek op dit terrein te entameren. 
De Rijksuniversiteit heeft dit verzoek in 1979 aanvaard, op voorwalarde, dat het onderzoek gefaseerd zou worden uitgevoerd. Dat wil zeggen, dat pas met beleidsgericht onderzoek en actie gestart zou worden, nadat meer precies duidelijk was geworden, warin zuid-Limburg zich op het gebied van zlekteverzuim van overig Nederland onderscheldt.

Deze opzet heeft geleid tot een eerste min of meer diagnosestellend rapport, dat gebaseerd was op desk-research (Soeters, 1980a). De belangrijkste bevindingen van dit rapport betreffende de afwezigheid wegens ziekte in z-Limburg luiden in het kort als volgt:

- In z-Limburg verzuimt men niet vaker dan elders in Nederland, maar blijft men langer weg als men zich eenmal heeft ziekgemeld;

- dit patxoon is leeftijds-, bedrijfstak- en geslachtsonafhankelijk.

Ten aanzien van mogelijke oorzaken van dit systematische patroon, werd het volgende gesignaleerd:

- de gezondheidstoestand van de zuidlimburgers is minder goed dan die van hun landgenoten; zuidlimburgers hebben een hogere sterftekans; verder leggen zij meer en intensiever riskante leefgewoonten aan de dag dan elders in het land gebruikelijk is;

- relatief meer dan andere Nederlanders komen Zuidlimburgers via het kanaal van ziektewet en WAO terecht in het niet-actieven-bestand;

- de infrastructurele voorzieningen op het gebied van de gezondheldszorg zijn, althans waren in 1979, in z-Limburg kwantitatief minder goed ontwikkeld; het beroep op die voorzleningen is in deze regio juist groter.

Al met al gaf het $z$-Limburgse ziekteverzuim een vervlechting van sociaal-economische, sociaal-medische en organisatorische componenten te zien (zle ook soeters, 1980b). Dit beeld van $\mathrm{z}$-Limburg vertoont overeenkomsten met hetgeen uit Brits onderzoek bekend is over NW-Engeland en Wales (Taylor 1974 en 1976). Deze regio's hebben telkenmale de hoogste ziekteverzuim-, maar ook sterfepercentages van geheel Engeland. Net zoals in $z$-Limburg lijken daar sociaal-economische factoren (mede-)verantwoordelijk voor de achterstand op gezondhelds (zorg) gebied.

Naar aanleiding van deze resultaten werd door de begelei- 
dingscomissie geoordeeld, dat vervolgondexzoek natar de riskante leefgewoonten en gezondheldstoestand van de zuIdIImburgers wel belangrijk, maar pas op langere termijn beleldseffectief zou zijn. Op korte termijn meex effectieve beleidswoorstellen zouden kunnen worden ontleend aan onderzoek met de volgende twee invalshoeken: enerzijds onderzoek met betrekking tot de verzuimauurverlengende invloed van de gezondheidszorg, anderzijds onderzoek met betrekking tot organisatie-invloeden op lange ziekteduren en WAO-instroom.

Een onderzoek van het laatste type is inmiddels door Nijhuls en soeters in 1982 en 1983 verslagen en gepubliceerd. Aan deze organisatiestudie, die zich baseert op informatie van sleutelrespondenten op het nivo van management en personeelsvertegenwoordiging, is ook nog een enquête onder werknemers toegevoegd. Aan een steekproef van werknemers van de aan het organisatie-onderzoek deelnemende bedrijven en instellingen zijn vragen gesteld omtrent hun perceptie van arbeid en gezondheid. De resultaten van deze enquête zullen in de loop van volgend jaar worden gerapporteerd.

Naast deze beide sterk op elkaar betxokken onderzoeken, die gericht zijn op de invloeden van arbeid op ziekte en gezondheid, is een derde onderzoek geëntameerd. Dit -hier beschreven- onderzoek richt zich op de verzuimduurverlengende effecten, die in de interactie tussen patiënt en gezondheidszorg kunnen ontstaan.

Met dit derde onderzoek doet zich de gelegenheid voor, om een relatief verwarloosd aspect van de problematiek van het langdurig ziekteverzuim in kaart te brengen. zoals uit het literatuuroverzicht van wiersma (1979) bijvoorbeeld blijkt, is het langdurig ziekteverzuim vanult diverse optieken vrij uitvoerig bestudeerd. Maar met name de invloed van de gezondheidszorg op lange ziekteduren is een relatief weinig geëxploreerd gebied. In deze lacune probeert dit onderzoek enigszins te voorzien.

1.2. Probleemstelling en reikwijate van het onderzoek in het kort

Aanleiding voor de hier verslagen studie vormt het feit, dat enkele jaren geleden in de Randstad door rordoix e.a. (1978) 
wexd vastgesteld, dat ca. 20 van alle ziektedagen bij ziektegevallen langer dan 6 weken, uit $z$ gn. wachttijden bestaat. Tijdens deze wachttijden wordt geen voortgang in de behandeIing van de ziekte geboekt. De veronderstelling hierbij is, dat als gevolg van deze wachttljden ook het herstel en werkhervatting later optreden. ziekteperioden zouden daarom langer duren dan strikt noodzakelijk is.

Op grond van gegevens betreffende het aanbor van en het beroep op gezondheidszorgvoorzieningen in zuid-Limburg, is er reden te veronderstellen, dat de wachttijdenproblematiek zich in die regio in versterkte mate voordoet (soeters. $1980 a$ en b). Op de vraag, hoe groot dile wachttijdenproblematiek in z-limburg is, en op meer algemene kenmerken van de interactle tussen patiënt en gezondheidszorg wordt in dit vers lag Ingegaain.

Daarnaast komt het proces van werkhervatting hier aan de orde. Ten aanzien van het moment en de wijze van werkhervatting bestaat namelijk beslissingsvrijheid bij de patiënt zelf (Philipsen, 1969a), terwijl ook de functionaris van de controlerende en/of uitkeringsinstantie hierop invloed heeft: Onvermijdelijk moet deze beslissingsvrijheld leiden tot verschillen in het tijastip en de wijze van werkhervatting, en daarmee tot verschilien in ziekteduren. onder meer de kwestie van het scheppen van zgn. aangepaste arbeid speelt hierbij een rol (SER-advies, 1982).

Hiermee zijn de twee vraagstellingen van deze studie verwoord, die een beschrijvend karakter hebben. Résumerend gaat het on het beschrijuen:

a. van wachttijden en anverwante aspecten van de behandeIIng van zleke werknemers en

b. van aspecten van de werkhervatting.

De antwoorden op deze beide vragen, en met name het vaststellen van de omvang van de wachttijdproblematiek, zijn eexst en vooral van betekenls voor de situatie in $z-L i m b u r g$. Maar daarnaast proberen wij in deze studie ook inzicht te krijgen in determinanten van wachttijden en lange ziekteduren. Primair gat het ons hierbij dan om determinanten uit de hoek van de patient-gezondheidszorg-interactie en het a anbod van gezondheldszorgvoorzieningen. Deze vragen hebben een verklarena karakter, samenvattend zijn zij als volgt te verwoorden: "welke factoren hangen samen met verschillen tussen zieke werknemers in wachttijden en ziekteduren"? Volgens de redenering van Phillpsen (1969b) hebben de antwoor- 
den op dit type vragen een grotere relkwijate dan het geografisch gebled, waarop het onderzoek in kwestie betrekking heeft. In ons geval impliceert dit, dat onze analyses met betrekking tot de determinanten van wachttijden en ziekteduren niet alleen betekenis voor $z$-Limburg hebben, max ook voor geheel Nederland.

Tot zover -zeer beknopt- de vraagstellingen en de reikwijdte van de antwoorden erop. On deze vraagstukken te bestuderen, zijn bij ruim 200 werknemers, die tenminste 4 weken ziek waren, twee interviews afgenomen, respectievelijk aan het begin en aan het einde van de ziekteperiode. Bovendien is via een aparte registratie een tiental kenmerken van elk kontakt, dat deze patiënten met gezondheidszorginstanties hadden, vastgelegd.

\subsection{Relevantile van het onderzoek}

In deze studie wordt in feite ingehaakt op de tradjties van zowel ziekteverzuimresearch als onderzoek naar het functioneren van. de gezondheidszorg. Dit betekent, dat deze studie om meerdere redenen en voor meerdere partijen relevante informatie zal kunnen opleveren.

Ten eerste kan men aan de hand van dit onderzoek wellicht weer iets meer zeggen over oorzaken van lange ziekteduren en arbeidsongeschiktheid. Hiermee is in principe en nationaleconomisch motief gediend, te weten, de vermindering van uitkeringen bij ziekte of arbeidsongeschiktheld. Maar bovendien proberen wij-zoals gezega- in deze studie ook de wisselwerking tussen gezondheidszorg en ziekteverzuim te betrekken. Wellicht kan deze poging informatie verschaffen voor die beleidsmakers, die geinteresseerd zijn in een herallocatie van de gelden binnen de collectieve sector. "Ter verduidelijking van het financiële gewicht van de problematiek nog de volgende gegevens: met uitgaven voor tijdelijke en blijuende arbeidsongeschiktheid alsmede voor de gezondheidszorg was in 1981 ongeveer $1 / 5$ gedeelte van het nationaal inkomen gemoeid; beide soorten uitgavenposten -uitkeringen en voorzieningen- zijn ongeveer even groot (v.a. Bosch \& Petersen, 1982).

Dan is er een tweede punt, warrom dit onderzoek relevant is. Langdurige ziekte en vooral definitieve arbeidsongeschikt- 
heid worden door veel betrokkenen als een minder wenselijke situatle gezien (Merens-Riedstra, 1981). Onder andere hangt dit samen met het maatschappelijk functie- en statusverlies en met het proces van verafhankelijking, dat langdurige ziekte met zich meebrengt (de Swaan, 1982). Bovendien kan langdurige ziekte bij de persoon in kwestie onzekerheid teweeg brengen over het blijven voortbestaan dan wel onvervuld blijven van zijn funktie. Verder kan met het verrichten van arbeid ook de regelmat in de tijdsbesteding van betrokkenen verdwijnen; dit $k$ an als negatief ervaren worden (Janssen en Ykema, 1983). Tenslotte zijn sinds kort de netto-uitkeringen bij definitieve arbeidsongeschiktheid verlaagd. Vandaar, dat nu meer dan tot voor kort ook voor uitkeringsgerechtigden financiële argumenten bij deze problematiek in het geding zijn. Met het verzamelen van kennis, ter vermindering van de kans op langdurig ziekteverzuim en arbeidsongeschiktheid, wordt derhalve ook een werknemersbelang gediend.

zoals al eerder gezegd, is een andere belangrijke doelstelling van dit onderzoek gelegen in het identlficeren van $z \mathrm{gn}$. wachttijden, dat wil zeggen, die perioden, waarin geen voortgang in het behandelingsproces wordt geboekt. Het spreekt voor $z i c h$, dat hiermee een direct patiëntenbelang is gediend. Men mag immers aannemen, dat vertraging in de behandeling onnodig fysiek en psychisch ongemak (pijn, angst, onzekerheid e.d.) voor de patiënt met zich meebrengt (Buys, 1982). Onder meer om deze reden wordt in dit onderzoek de patiënt ook als consument ten tonele gevoerd, namelijk door het patiëntenoordeel over aspecten van de medische zorg aan de orde te stellen.

Tenslotte worden in dit onderzoek indicatoren van medische consumptie bestudeerd; het gaat dan on zaken als aantalien huisartsenconsulten, verwijspercentages e.d. Hiermee kan dit onderzoek geplaatst worden in die onderzoeksstroming, die zich bezighoudt met kennisverwerving inzake de kostenstructuur van de gezondheidszorg (bijv. Van der zee en Posthumus, 1980).

1.4. Opbouw van dit verslag

Naast dit inleidende hoofdstuk bevat dit onderzoeksverslag nog een achttal andere hoofdstukken. In het eerstvolgende 
hoofdstuk wordt dieper ingegaan op de achtergronden van de hier gestelde vragen en wordt een beknopt gehouden overzicht van de relevante literatuur geboden. In hoofastuk $3 \mathrm{zal}$ de opzet en de uitvoering van het onderzoek uit de doeken worden gedaan. Daarnaast bevat dit hoofdstuk een non-responsanalyse. In hoofdstuk 4 worden aspecten van de behandeling bestudeerd. Daar zullen onder meer de al vaker genoemde wachttijden worden beschreven. In het vijfde hoofdstuk staat het proces van al dan niet werkhervatten centraal, met inbegrip van het onderhandelingsproces over eventuele aanpassingen in het werk. Daarmee wordt het beschrijvende gedeelte van deze studie afgesloten.

Ter voorbereiding van de verklarende analyses worden in hoofdstuk 6 de onafhankelijke en afhankelijke variabelen in detail besproken en worden de te bestuderen vragen geëxpliciteerd. Bovendien komen in dit hoofdstuk de onderlinge samenhangen van de onafhankelijke variabelen per rubriek aan de orde. In hoofdstuk 7 volgt dan de presentatie en bespreking van een drietal verklarende analyses met betrekking tot de wachttijden, die de onderzochte zieke werknemers hebben meegemaakt. In hoofdstuk 8 wordt volgens hetzelfde stramien de ziekteduur aan nadere analyse onderworpen.

Hoofdstuk 9 -tenslotte- slult deze studie af met een samenvatting van de belangrijkste bevindingen, een bespreking van de beleidsrelevantie van de resultaten mede in het licht van nieuwe regelgeving, en met voorstellen voor verder onderzoek. 
HOOFDSTUK 2.

LANGE ZIEKTEDUREN EN WACHTTIJDEN: EEN LITERATUUROVERZICHT.

2.1. Inletding

In het eerste hoofdstuk is uiteengezet, dat deze studie gericht is op het beschrijven en verklaren van wachttijden en lange ziekteduren. Hierbij vormen twee bestaansredenen van de sociale wetenschappen in de geneeskunde de uitgangspunten:

- het ontstaan, maar vooral ook het verloop van ziekte worden onder meer beinvloed door "maatschappelijke" factoren (bijw. Millard Waltz, 1981; Appels, 1982; Drop \& Houben, 1983), en

- het gedrag van mensen rondom ziekte en gezondheid valt niet automatisch samen met medisch-biologische standaarden (bijv. Suchman, 1965; Tuckett, 1977).

Ter toelichting: veel mensen zijn in medisch-biologische zin ziek, maar gaan niet naar de dokter (Cassee, 1973; Tuckett, 1977), of melden zich niet ziek voor hun werk (Vorsorge-Untersuchungen, 1970). Het omgekeerde verschijnsel komt ook voor. Met andere woorden: de biomedische definitie van ziekte overlapt slechts bij een gedeelte van alle aandoeningen de sociaal-medische definitie (Twaddle, 1981; vergelijk ook Drop \& Houben, 1983).

Gegeven deze uitgangspunten, zijn invloeden op ziekteverloop en ziektegedrag niet alleen afkomstig van somatische, maar ook van psychische en sociaal-culturele, c.q. sociaal-economische factoren (bijv. Cassee, 1973). In deze studie zal meer in het bljzonder de groep der sociaal-culturele/soclaal-economische invloeden behandeld worden. Hiermee beperkt het onderzoek zich tot het domein der medische sociologie, met een uitstapje naar het gebied van de gezondheidszorgeconomie.

Voortbordurend op kennis van deze beide vakgebieden zal in het navolgende eerst een overzicht gegeven worden van de tot dusverre geidentificeerde oorzaken van langdurig ziekteverzuim (par. 2.2.). De problematiek van het langdurig verzuim 
vormt immers de directe achtergrond van deze studie. Blijken zal, dat cantrent het langdurig ziekteverzuin reeds veel bekend is. Er is echter sprake van één duidelijke lacune in de kennis: het effect van de patiënt-gezondheidszorg-interactie op lange ziekteduren. Dit is dan ook -niet voor niets- het thema, dat in deze studie verder geëxploreerd zal worden. Om hiermee te beginnen, behandelen wij in par. 2.3. de problematiek rondom de capaciteit en organisatie van de gezondheidszorg, voorzover deze in verband te brengen valt met wachttijden. Daarnaast kunnen twee concrete gebeurtenissen, die zich in een ziekteperiode kunnen voordoen, ten grondslag Iiggen aan het ontstaan van vertraging tijdens de behandeling. Dit betreft enerzijds het uitstellen van doktersbezoek door patiënten en anderzijas het verwijzen door artsen naar andere echelons in de gezondheidszorg. Waarom beide gebeurtenissen nauw in verband staan met wachttijden en onder welke omstandigheden deze gebeurtenissen vaker voorkomen; behandelen wij respectievelijk in de paragrafen 2.4. en 2.5. Een samenvatting van het voorafgaande wordt tot besluit in par. 2.6. geboden.

\subsection{Langdurig ziekteverzuim}

Op verschillende plaatsen is in de voorgaande tekst al vermeld, dat de problematiek van de lange ziekteduren (vanaf 4-6 weken) niet alleen de aanleiding tot het onderzoek, maar uiteindelijk ook de kern van de vraagstelling vormt. Hiermee voegt deze studie zich in een rijke Nederlandse traditle van ziekteverzuimonderzoek; hieraan dient evenwel onmiddelijjk. toegevoegd te worden, dat slechts in een viertal andere studies het langdurig ziekteverzuim aan de hand van unieke ziektegevalien van werknemers geanalyseerd is. Dit zijn de studies van wiersma (1979), Merens-Riedstra (1981), de Jong e.a. (1981) en van Luyckx (1982). De resultaten van deze studies alsmede van enkele andere onderzoeken worden hier beknopt weergegeven.

ten eerste blijkt, dat ziektevariabelen een dominerende rol spelen bij de verklaring van de kans op langdurig verzuim. De kans op langdurige ziekte is des te groter, naarmate de prognose omtrent herstel ongunstiger en de binding aan de ziekterol sterker is (wiersma, 1979), an- 
ders gezega: naarmate de behoefte aan hulp sterker en de perceptie van de zlekte ernstiger is, (Merens-Riedstra, 1981) en: naarmate in het recente verleden vaker en langduriger verzulind is (de Jong e.a., 1981; Iuyckx, 1982, vgl. ook Schokking-siegerist, 1979). Naar diagnose gespecificeerd blijkt, dat aandoeningen aan het bewegingsapparaat, zenuwstelsel en zintuigen alsmede ongevallen langere ziekteduren veroorzaken dan andere diagnosegroepen (Merens-Rledstra, 1981).

- er kan verder geen misverstand over bestaan, dat in bearljfseconomisch slecht renderende bedrijven meer langdurig ziekteverzuim voorkomt dan gemiddeld (wiersma, 1979, de Jong e.a., 1981).

- de situatie op de werkvloer blijkt eveneens een zwaarwegende factor bij het ontstaan van langdurig ziekteverzuim te zijn. De kans op lange ziekteduren is grotex, wanneer in de werksituatie sprake is van: ongeschoolde handarbeld (Merens-Riedstra, 1981), een grotere werkbelasting (Wiersma, 1979) of tempodwang (de Jong e.a., 1981), een grotere fysieke belasting, een slechtere sfeer op het werk en/of geringere promotiemogelijkheden (de Jong e.a., 1981; Eschweiler e.a., 1979). Verder is de kans op langdurige ziekte geringer, naarmate men van de kant van het bedrijf meer contacten met zieke werknemers onderhoudt en men meer geneigd is, aanpassingen in het werk aan te brengen, teneinde werkhervatting te bevorderen (de Jong e.a., 1981; Ris, 1978).

- ook blijkt de kans op langdurig ziekteverzuim groter te zijn, naamate de inkomensachteruitgang bij ziekte kleinex 1s (de Jong e.a., 1981; in de VS: Nagy en Hadley, 1972).

- voort blijkt langaurig zlekteverzuim meer voor te komen in stedelijke woonmilieus (Wlersma, 1979). De geringere sociale controle en de ruimere ziektedefinitie, die in stedelijke woonmilieus gebruikelijk zijn, vormen hier de achtergrond (Philipsen, 1969a).

- daanaast blijken langdurig zieken zich te onderscheiden doox gevoelens van machteloosheid (Wiersma, 1979) en/of door een meer vijandige houding ten opzichte van de buitenwereld (Merens-Riedstra, 1981).

- tenslotte zijn er nog twee resultaten gevonden, die tegen de verwachtingen van de onderzoekers in gingen. Ten eerste bleek een grotere mate van ervaren psycho-sociale 
stress samen te gaan met relatief kortere ziekteduren (Wiersma, 1979); in de tweede plats bleek ex een negatieve samenhang te bestaan tussen het aantal werkinconveniënten en de kans op een lange ziekteduur (de Jong e.a., 1981). Een verklaring voor het laatste resultaat moet men zoeken in het zogenaamde "healthy-worker-effect". Werknemers, die niet tegen bezwarende werkomstandigheden bestand zijn, stellen er zich bij voorbaat niet aan bloot, worden er niet aan blootgesteld of verdwijnen sneller dan anderen uit zulke arbejdsomstandigheden (OIsen, 1981).

- tot besluit de invloeden uit de gezondheidszorg op ziekteduren. Tot op heden zijn er geen specifieke relaties vastgesteld tussen aspecten van de patiênt-gezonaheidszorg-interactie enerzijds en langdurig zlekteverzuim anderzijds. Wel hebben Tordoir c.s. (1978) vastgesteld, dat er een correlatie bestaat tussen het aantal wachtdagen en de viteindelijke ziekteduur. Verder heeft Luyckx (1982) geconstateerd, dat zich met name in het begin van langdurige ziekteperioden nogal wat met de organisatie van de gezondheidszorg samenhangende problematiek voordoet. Tenslotte bleek uit het onderzoek van wiersma (1979), dat in de ogen van verzekeringsgeneeskundigen 28 van de ziekteduren relatief te lang was uitgelopen, mede als gevolg van factoren betreffende de organisatie van de gezondheildszorg.

In vergelijking met vele andere invloeden op langdurig verzuim, zoals de relatie tussen arbeid en ziekte, vormt de werking van de gezondheidszorg een nog relatief onbekend terrein. Onder meer om deze reden wordt in deze studie juist hierop het vizier gericht. Te beginnen met een literatuuroverzicht over de organisatie van de Nederlandse gezondheidszorg in relatie tot het wachttijdenvraagstuk.

2.3. De organisatie van de gezondheidszorg en het wachttijdenprobleem

Zoals bekend, hebben zowel het aanbod als de vraag naar gezondheidszorgvoorzieningen sinds de Tweede Wereldoorlog een grote vlucht genomen (bijv. Fuchs, 1968; Philipsen, 1977). ongetwijfeld valt met deze ontwikkeling een belangrijk ge- 
deelte van de verlenging van de verzuimduur in die periode te verklaren (Philipsen, 1977). Niet voor niets spreekt de Groot in dit verband al in 1967 van latrogene verzuimduurverlenging, een term, die later met het oog op de WAO-problematiek zelfs opschuift naar iatrogene invalidering (CCOZbrochure, 1982).

Dit toegenomen beroep op medische voorzieningen wordt niet door iedereen even positief beoordeeld (bijv. Illich, 1976; Van Doorn-de Leeuw, 1977). De vraag naar de legitimiteit van deze ontwikkeling, of -anders gezegd- de vraag naar de effectiviteit van het medisch handelen blijft hier evenwel buiten beschouwing. Daarentegen vormen aspecten van de efficiëntie van het medisch functioneren wel onderwerp van deze studie.

In het vorige hoofdstuk is er al op gewezen, dat lang niet alle patiënten, die voor hun genezing hulp bij de gezondheidszorg zoeken, ook een continu doorlopend behandelingsproces meemaken. Dit is voor Nederland empirisch vastgesteld door Tordoir c.s. (1978); ook in deze studie willen wij een poging tot identificatie van $\mathrm{zgn}$. wachttijden ondernemen.

De problemen, die ten grondslag liggen aan het feit, dat niet altijd voortgang in het behandelingsproces wordt geboekt, kan men globaal als volgt beschrijven. In de afgelopen 20 jaren hebben zich in de gezondheidszorg processen van schalvergroting, specialisatie en differentiatie voorgedaan (Kinston, 1982). Deze processen waren aan de ene kant het gevolg van de toenemende vraag naar medische dienstverlening en aan de andere kant van de uitdijende medisch-technische mogelijkheden (Twaddle, 1981). In de toch al ingewikkelde - uit echelons opgebouwde- gezondheidszorg hebben deze processen tot een situatie geleid, waarin planning en coördinatle te wensen overlaten en de dienstverlening sterk verkokerd is (Mechanic, 1976). Sultan en Enos (1977) gaan zelfs zover, dat $z 1 j$ de gezondheldszorg om deze reden een "nonsysteem" willen noemen.

Een gevolg van dit proces is geweest, dat het aanbod van gezondheldszorgvoorzieningen per speclalisme, maar ook per regio valk ongelijk ontwikkeld is (Schrijvers, 1980; soeters, 1980a; in de V.S. bijv. Wemnberg Gittelsohn, 1973; in Groot-Britannie: Culyer, 1979). Personeelsformatieplanning schittert tot op heden in de gezondheldszorg door afwezigheid (bijv. Abe1-smith, 1976; Greep, 1983b). Niet voor niets worden in de in Nederland op stapel staande Wet Voorzienin- 
gen Gezondheidszorg mogelijkheden geschapen om op regionaal nivo tot een planning van samenhangende voorzleningen te komen.

In de bestaande situatie kunnen wachttijden ontstaan tijdens een verwijzing van een echelon naar een ander, maar ook tijdens een verwijzing binnen een en hetzelfde echelon. Dok zonder kennis van operations research (bijv. Ackoff en Sasione, 1968) kan men stellen, dat wachttijden ontstaan, wanneer het aanbod van gezondheidszorgvoorzieningen per tijds- en geografische eenheid te kort schiet bij de vraag ernaar. Dit kan een incidenteel verschijnsel zijn, maar ook een structureel, zoals de beruchte wachtlijsten uit het Engeland van de National Health service overduidelijk laten zien; met name de wachttijd voor ziekenhuisopnamen vormt daar een belangrijk probleem (Culyer, 1979; Frost, 1980; vickers et al, 1980). Overigens lijkt het daar vigerend en van vele westerse landen afwijkend honoreringssysteem van specialisten ook een rol bij het ontstaan van wachttijden te spelen (Frost, 1980). In Nederland is de situatie niet zo zorgwekkend, al zijn er -zoals gezegd- regionale verschillen in het gezondheidszorgaanbod (Schrijvers, 1980; Soeters, 1980 a). Deze leiden ongetwijfeld tot regionale verschillen in verwijzingswachttijden.

Wij doelen hiermee vooral op verwijzingswachttijden tijdens het extramurale behandelingsproces. Dit laat onverlet, dat ook tijdens ziekenhuisopnamen tijd verloren kan gaan. Het bestaan van dergelijke vertraging tijdens opnamen is in Nederland reeds in 1963 door Querido vastgesteld, en meer recent door Creemers (1974). Dit onderwerp, dat van bijzonder belang is bij de bestudering van de kostenstructuur van het ziekenhuiswezen, valt evenwel buiten het bestek van onze studie.

Een tweede probleem, dat zich in de gezondheidszorg voordoet, betreft de vaak gebrekkige communicatie tussen de diverse echelons en specialismen. Samenwerking tussen huisarts en specialist is eerder af-dan aanwezig, de onderlinge taakafbakening onduidelijk en van een gezamenlijke behandelingsdoelstelling is dikwijls geen sprake (de Melker, 1974). Dit kan bijvoorbeeld tot gevolg hebben, dat tijdrovend werk dubbel wordt gedaan (Fuchs, 1968; Merens-Riedstra \& v.d. Ende, 1973), of dat patiënten relatief te snel doorverwezen worden. Om dit laatste te voorkomen, worden momenteel expe- 
rimenten met $\mathrm{zgn}$. diagnostische centra ondernomen, met als doel an het arsenal aan diagnostische hulpmiddelen van de hulsarts te vergroten (Peters v. Bree, 1979 ; voor een beschrljuing van dezelfde problematiek in Engeland, zie Wilkes, 1980).

Een consequentie van de verbrokkelde zorgverlening kan zijn. dat patiénten tussen de diverse echelons verloren raken, of -in terminologie van Tordoir c.s. (1978)-stuurloos worden: hiermee wordt gedoeld op de situatie, dat de patiënt niet meer behandeld wordt, ook geen verwijzing meer ontvangt, maar evenmin (volledig) hersteld is verklaard. Met andere woorden, gaat het hier om situaties, waarin de continuiteit van de zorg in de knel komt.

De kans op dit soort situaties wordt nog vergroot door het In Nederland vigerende stelsel var een gescheiden behandeling en controle (Grond, 1980). Als gevolg van dit stelsel hebben behandelende artsen geen verantwoordelijkheid ten aanzien van het ziekteverzuim en de datum van werkhervatting van hun patiénten; aan de andere kant hebben de daarvoor wel verantwoordelijke artsen (de verzekeringsgeneeskundigen) geen weet van de behandeling van hun verzekerden.

voor de ultoefening van vooral de verzekeringsgeneeskundige taak is overleg tussen de behandelende en de verzekeringsgeneeskundige sector derhalve noodzakelijk. Maar daaraan wil het nogal eens schorten, zoals een viertal Nederlandse studies laat zien.

In 1973 deden Merens-Rledstra en v.d. Ende onderzoek naar de behandeling van 23 hartinfarctpatiënten. zij kwamen o.a. tot de conclusie, dat noch de verzekeringsgeneeskundigen (VG-en) van de Bedxijfsverenigingen noch die van de GMD vaak contact met de behandelende sector hadden gehad. Bovendien was er alleen mar sprake van eenzijaige informatie-overdracht en niet van wederaijas intercollegiaal overleg. Tot soortgelijke bevindingen $\mathrm{kwam}$ het onderzoeksteam van $\mathrm{V}$. Mansvelt (1975). Zij analyseerden 301 keuringsgevallen van neurologische patiënten; bij 15 van deze patiënten was naar het oordeel van deze artsen-onderzoekers sprake van een duidelijke iatrogene component, deze was het gevolg van "onvoldoende contact en eenheid in beleid tussen de verzekeringsgeneeskundige en de behandelende sector". ook de Jong-Hylkema (1973) constateerde het bestaan van zulke "door ondulidelijkheid en gebrek aan coördinatie in de medische sector diffuus beinvloede dagen". Meer recent nog publiceerde Groothoff 
(1980) een studie over dezelfde thematiek bij 231 3e-maandsverzuimgevallen. zijn conclusies over de samenwerking tussen huisarts, specialist en VG: "Er is grote behoefte aan advies van elkaar, maar er is weinig overeenstemming over wie de behandeling en werkhervatting coördineert; de activiteiten met betrekking tot behandeling en werkhervatting worden nogal eens als inadequat beschouwd."

Deze vier onderzoeken illustreren het bestaan van een communicatieprobleem in de Nederlandse gezondheidszorg in voldoende mate. Het is een problematiek, die zorgen baart, getuige de diverse rapporten en artikelen, die in de laatste jaren over de samenwerkingsrelaties van artsen en de intercollegiale informatie-uitwisseling vexschenen zijn (bijv. Dijkstra \& Tordoir, 1974; Smulders, 1975; v. Mansvelt, 1975; Grond, 1980; Grond en De Pater, 1980; V.d. Kooy, 1983; Lamers, 1983; Streng, 1983). Onder meer terwille van een formele regeling van het intercollegiaal overleg, heeft men momenteel in de KNMG stappen genomen. Deze worden evenwel van de kant van VG-en als volstrekt onvoldoende gekenschetst (Grond \& De Pater, 1980). Met name het voorschrift, om alleen objectieve medische gegevens aan VG-en te verstrekken, lost -in de visie van Grond en De Pater (1980)- geen enkele moeilijkheid op. Het intercollegiaal overleg kan bovendien nog bemoeilijkt worden door de wens tot geldelijke vergoeding voor schriftelijke informatieverstrekking van behandelende artsen (de Graaf e.a., 1983; streng, 1983).

Met dit alles blijft het probleem bestaan van een weinig gestructureerde samenwerking enerzijds binnen de behandelende sector en anderzijds tussen de behandelende, vexzekeringsgeneeskundige en bedrijfsgezondheidskundige sector. Hierdoor kan een teveel aan of juist ook een caesuux in de behandeling van patiënten ontstaan. Dit is ook de constatering in een recente adviesaanvrage van de regering aan de Nationale Raad voor de Volksgezondheid; deze handelt over soclaal-medische begeleiding bij ziekteverzuim en arbeidsongeschiktheid (De Graaf, Kappeyne van de Coppello en van der Reyden, 1983).

Hiermee kunnen wij deze beknopte schets van een tweetal problemen in de gezondheidszorg afsluiten. Beide problemen, te weten het ongelijke aanbod van gezondheidszorgvoorzieningen en de gebrekkige samenwerking en communicatie tussen de diverse echelons, veroorzaken wachttijden. Het laatste kan on- 
der meer lelden tot de zogenaande "stuurloze dagen"; tijdens deze perioden wordt geen plan voor behandeling uitgezet of uitgevoerd. Volgens het zorgvuldig opgezette onderzoek van Tordoir e.a. (1978) nemen deze stuurloze dagen ruim 28 van de totale verzuimdur van langdurig zieke werknemers in beslag.

De tweede vorm van wachttijden betreft de verwijzingswachtdagen. Deze beslaan ruim $15 \%$ van de volledige verzulmduur van de langdurig zieke werknemers in het onderzoek van Tordolr e.a. (1978). Deze wachttijden zijn-zoals eerder in deze paragraaf gezegd- het gevolg van een relatief tekort aan gezondheidszorgaanbod, met name in het tweede en derde echelon.

Tenslotte komt $2 \%$ van de gemiddelde volledige verzuimduur op conto van de patiënt, die deze tijd laat verlopen, alvorens zich tot de gezondheldszorg te wenden. Al met al bestaat -althans volgens de warneming van Tordoir c.s. - 19,58 van de gemiddelde verzuimduur van langdurig zieke werknemers ( $>6$ weken) uit wachttijden.

Meer is over de omvang van wachttijden in Nederland tot op heden niet bekend. over de vraag, welke typen van patiënten meer wachttijden meemaken dan anderen, is evenmin erg veel bekend. Ult de analyses van Tordoir c.s. blijkt alleen, dat langere wachttijden voorkomen bij bepaalde diagnoses (neurologische aandoeningen, bewegingsorganen) en voorts bij de lagere beroepsnivo's. Bovendien is uit dat onderzoek naar woren gekomen, dat de niet-werkhervatters gemiddeld langere wachttijden meemaken dan werkhervatters.

Tot zover enkele resultaten uit het onderzoek van Tordoir c.s.. Verderop in hoofdstuk 4 staat meer informatie over wachttijden in Nederland beschreven, dan niet meer alleen afkomstig uit het rordoir-onderzoek, maar ook uit eigen nieuw data-material.

\subsection{Uitstelgedrag}

zojuist werd een type wachttijd genoemd, dat niet tijdens verwijzing ontstaat. Dit is de zgn. stuurloze periode, waarin geen plan voor behandeling wordt uitgezet of uitgevoerd. voor alle duidelijkheid: deze periode heeft geen betrekking op het tijdsverloop tussen laatste contact met de gezond- 
heidszorg en werkhervatting. De stuurloze periode is -zoals zojuist werd beschreven- onder meer het gevolg van de structureel gebrekkige communicatie tussen de behandelende en verzekeringsgeneeskundige sector. Maar daarmee is niet alles over de achtergronden van stuurloze perioden gezegd. Immers ook de patiënt zelf heeft invloed op het ontstaan en de lengte van stuurloze perioden. Een actieve patiënt, die bij een instantie is uitbehandeld, zal zich namelijk snel tot zijn huisarts of VG wenden, zonder een oproep van de laatste af te wachten.

Het ontstaan van dit type wachttijd is dus ondex meer het gevolg van wat in de medische sociologie wel het uitstelgedrag van de patiënt wordt genoemd. Met een ander woord kan men hier spreken van "patiëntentraagheid". Uitstelgedrag is een relatief vaak bestudeerd fenomeen, onder meer met het oog op de preventie van nieuwvormingen (bijv. Blackwell, 1963; Cassee, 1973; Jessen, 1974; Greenwald, Becker and Nevitt, 1978; Neven, 1980).

In het resterende gedeelte van deze paragraaf wordt nu beknopt de stand van zaken met betrekking tot dit onderwerp uiteengezet. Vooraf moet daarbij wel de kanttekening worden gemakkt, dat de bevindingen uit de literatuux vooral betrekking hebben op het tijdsverloop tussen het signaleren van symptomen en het eerste kontakt met de gezondheidszorg. Om deze reden hebben deze gegevens wellicht een beperkte betekenis voor de hier onderscheiden stuurloze perioden; deze kunnen immers per definitie pas na het eerste kontakt met de gezondheidszorg ontstaan. Niettemin kan men veronderstellen, dat de thematiek van het uitstelgedrag raakvlakken vertoont met de nog niet eerder bestudeerde problematiek van de stuurloze perioden. In beide gevallen -kan men zeggen- is ex sprake van "patient"s delay".

Omtrent de karakteristieken van patiënten, die (langaurig) uitstellen, is het volgende bekend:

- zij zijn en ze vinden zichzelf minder ernstig ziek (Cassee, 1973), of anders geformuleerd: de urgentiegraad van hun klacht(en) is gemiddeld lager (Neven, 1980).

- Uitstelgedrag komt meer voor bij ouderen (Blackwell, 1963; Jessen, 1974; Neven, 1980). Een verklaring voor dit robuuste verband kan zijn, dat oudere patiënten doorgaans minder acute klachten en bovendien meer ervaring met hun klachten hebben. Misschien zijn ouderen 
door deze grotere ervaring ook vaker van mening, dat doktersbezoek weinig effect zal sorteren. Tenslotte hanteren oudere patiënten wellicht een wat meer traditionele en ingeperkte ziektedefinitie.

- vrouwen stelien gemiddeld meer ult dan mannen (Blackwel1, 1963; Cassee, 1973; Jessen, 1974; Neven, 1980). Als verklarling hiervoor wordt aangevoerd, dat moeders van (kleine) kinderen vaak een geringere mogelijkheid hebben om naar de dokter te gaan. Dit resultaat correspondeert met de volkswijsheid, dat "een huisvrouw niet ziek kan zijn".

- Mensen met lagere opleidings- en/of beroepsnivo's stellen meer uit (Blackwe11, 1963; Cassee, 1973; Jessen, 1974; Greenwald et al., 1982). De algemene uitleg van dit verband komt exop neer, dat mensen met lagere beroepsnivo's een geringere kennis van ziekte hebben en ex bovendien een meer traditionee1-magische ziektebenadering op na houden. Als gevolg hiervan zouden de lager opgelelden bij waarneming van symptomen vaker met angst en ontkenning reageren dan mensen met een meer modernwetenschappelijke ziektebenadering (Cassee, 1973). Voorzover deze relatie buiten Nederland wordt geconstateerd (bijv. Greenwald et al., 1982), kunnen niet of slecht verzekerde ziektekosten ook een rol in dit verband spelen.

Uitstelgedrag gaat verder samen met een minder sterk geluksgevoel (Cassee, 1973), of -tegenovergesteld geformuleerd- met een sterkere mate van onwelbevinden (Jessen, 1974). Mensen met een algemeen gevoel van onbehagen zouden eerder de nelging hebben, op klachten emotioneler te reagexen door ontkenning of vluchtreacties.

Uitstelgedrag komt eveneens vaker voor bij patiënten, wer huisarts relatief oud is en bovendien met een vrij spreekuur in plaats van een afspraakspreekuur werkt (Neven, 1980). Deze kenmerken van de huisarts werken kennelijk drempelverhogend.

- Tenslotte, stellen mensen langer uit, naarmate ze al langer niet meer naar de dokter zijn geweest (Greenwald et a1., 1982), of in het algemeen al een lagere doktersbezoekfrequentie hebben (Cassee, 1973). Recente ervaring met de gezondheldszorg leidt er klaarblijkelijk toe, dat nleuw doktersbezoek minder lang wordt uitgesteld. 
Naast deze in diverse studies steeds weer terugkerende sociaal-culturele en -structurele kenmerken, zijn ook wel meer psychologisch getinte variabelen in verband met uitstelgedrag ontdekt; o.a. gaat het daarbij om het vermogen met angst om te kunnen gaan (bijv. Blackwell, 1963; Greenwald et al., 1982).

\subsection{Het doorverwijzen}

Zojuist hebben wij het uitstellen van doktersbezoek in verband gebracht met het ontstaan van stuurloze perioden. Deze vormen een kwantitatief niet onbelangrijk type wachttijd. Maar eerder al is gebleken, dat wachttijden, die tijdens de verwijzing in of naar tweede of derde echelon ontstaan, verreweg het grootste gedeelte van alle wachtdagen in beslag nemen.

Nu zal iedereen snel in kunnen zien, dat aan het ontstaan van verwijzingswachtdagen een gebeurtenis voorafgaat: de verwijzing zelf. Wil men derhalve meer inzicht in het ontstaan van verwijzingswachtdagen krijgen, dan zal men dus eerst het proces van al dan niet doorverwijzen moeten bestuderen. Dat zullen wij in hoofdstuk 7 doen op basis van ons eigen materiaal en op deze plaats op grond van de reeds bestaande literatuur hieromtrent. Wij zullen bij dit literatuuroverzicht een onderscheid maken tussen patiënt- en gezondheidszorgkenmerken, die van invloed zijn op het doorverwijzen.

\section{Patiëntkenmerken}

De kans op een verwijzing is in de eerste plats groter, naarmate ex meex sprake is van ernstig ziekteaanbod en minder van psycho-sociale problematiek (Rutten, 1978). Meer medische consumptie in het verleden (o.a. vila ziekenhulisopnamen) en een'algemeen minder goede gezondheidstoestand vergroten deze kans evenzeer (Van vliet en van de ven, 1982). verder blijken vrouwen vaker doorverwezen te worden dan mannen en personen met hogere opleidingsnivo's vaker dan personen met gemiddeld lagere opleidingen (Rutten, 1978). Tenslotte bestaat onduidelijkheid over de vraag, of ziekenfondsverzekerden onder de ceteris-paribus-clausule vaker 
doorverwezen worden dan andere verzekerden (V.d. Gaag, 1978; Rutten, 1978; V. vilet v.d. Ven, 1982).

Kenmerken van de gezondheidszorg:

Ten aanzien van verwijzingscontacten lijken kenmerken van het gezondheldszorgaanbod van grote beinvloedende betekenis te $z 1 j n$ :

- ten eerste bestaat in Nederland nawwelijks twijfel over het inzicht, dat vaker doorverwezen wordt, naarmate de afstand tot het ziekenhuis geringer is (Kruidenier, 1977; V. Aert en Hoeksma, 1980; Dopheide, 1982; V. Vliet \& v.d. Ven, 1982). Deze afstandseffecten zijn zo sterk, dat men bij de vestiging van gezondheidszorgvoorzieningen hier zelfs uitdrukkelijk rekening mee zou moeten houden (Calvo \& Marks, 1973: Magnusson, 1980). In nauw verband hiermee staat de bevinding, dat de urbanisatiegraad alsmede de bevolkingsdichtheid van een geografisch gebied positief correleren met het aantal doorverwijzingen (bijv. Aert \& Hoeksma, 1980; Hooymans, 1983). Overigens hoeft een hoger verwijzingspercentage in verstedelijkt woongebied niet alleen te wijzen op het effect van een ruim en nabij gezondheidszorgaanbod, maar kan dit ook het gevolg zijn van de ruimere ziektedefinitie, die in verstedelijkte woonmilieus gehanteerd wordt (Philipsen, 1969a; v. Aert \&oeksma, 1980).

- ten tweede blijkt er een positief verband te bestaan tussen het relatieve aanbod van intramurale voorzieningen en specialistische hulp enerzijas en het aantal doorverwijzingen anderzijds (V. Rert \& Hoeksma, 1980; Dopheide, 1982, Hooymans, 1983). Soortgelijke verbanden zijn in de V.S. dcor Wennberg Gittelsoh (1973) en in Canada door Evans (1974) geconstateerd.

- over het effect van de huisartspraktijkgrootte c.q. de hulsartsendichtheid op het doorverwijzingspercentage bestaat nog onzekerheid; vaak wordt ervan uitgegaan, dat zo"n effect er niet is (V. Aert \& Hoeksma, 1980; Hooymans, 1983). Boots (1983) stelt evenwel in zijn zeer recente studie vast, dat bij een toenemende praktijkgrootte het aantal verwijzingen per 100 consulten afneemt.

- daarentegen bestat er op geaggregeerd nivo wel een duidelijk positief verband tussen het relatieve aantal be- 
jaarden in een verzorgingsgebied en het verwijzingspercentage ( $V$. Aert \& Hoeksma, 1980). Een hogere morbiditeit in zo"n gebied vormt hier naar alle waarschijnlijkheid de voornaamste achtergrond van. Vermoedelijk vormt een hogere morbiditeit eveneens een verklaring voor het feit, dat in de drie zuidelijke provincies van Nederland meer doorverwezen wordt dan elders ( $V$. Aert Hoeksma, 1980; Dopheide, 1982; zie ook: Soeters, 1980a).

- hiermee zijn de belangrijkste inzichten omtrent het doorverwijzen op geaggregeerd nivo wel genoemd. Maar er is ook vastgesteld, dat binnen een en hetzelfde geografische gebied een inter-arts-variabiliteit ten aanzien van het doorverwijzen kan bestaan (bijv. Rutten, 1978). Deze variabiliteit in doorverwijzen sluit aan op de door Gexritsma en smal (1982) geconstateerde grote individuele variaties in medisch handelen. Dit geldt volgens hun onderzoek zowel voor huisartsen als internisten, zij het bij internisten in mindere mate. voor een verklaring van het verschil in doorverwijzen kan voorts gewezen worden op de recente bevinding, dat het verwijscijfer op praktijknivo relatief kleiner is, naarmate de huisarts er een bredere taakopvatting op na houdt. Hoe groter het taakdomein, dat de huisarts zich toeeigent, des te minder zal hij geneigd zijn door te verwijzen (Dopheide, $1982)$.

Al uit een eerdere W-Duitse studie (Hummel, Kaupen-Haas en Kaupen, 1970) was gebleken, dat opvattingen van huisartsen van invloed zijn op het doorverwijzen. Met name de vraag, naar welke arts de patiënt doorverwezen wordt, wordt (mede) bepaald door diens professionele status in het plaatselijk netwerk van artsen. Zeer recent onderzoek van Ludke (1982) laat verder zien, dat bij de beslissing om al-dan-niet door te verwijzen, diverse factoren door de betreffende artsen meegewogen worden. Daarbij gaat het uitdrukkelijk niet alleen om medischtechnische overwegingen, maar ook om het belang van de patiënt. Afgewogen worden onder meer het ongemak en de kosten van de verwijzing voor de patiënt, alsmede diens verwachtingen omtrent het nut van de verwijzing. Dat verwijzingen -tenslotte- niet alleen ontstaan op initiatief van de huisarts, maar vaak ook uitdrukkelijk op verzoek van de patiênt, is vastgesteld door Dophelde en Nijhout (1982). Voor ziekenfondsverzekerden bedroeg 
in hun onderzoek het aantal verwijzingen, dat als "op initiatief van de huisarts" werd geclassificeerd, slechts $32 \%$.

Tot zover het overzicht met betrekking tot de determinanten van het doorverwijscijfer.

\subsection{Samenvatting}

In dit hoofdstuk is een overzicht gegeven van de -voorname$11 \mathrm{jk}$ in het Nederlandse taalgebied- vastgestelde determinanten van lange ziekteduren. Daaruit kwam onder meer naar voren, dat duurvexlengende invloeden uit de patient-gezondheidszorg-interactie nog weinig bestudeerd zijn. In verband hiermee is vervolgens geschreven over het bestaan en oorzaken van wachttijden tijdens de behandeling van langdurig zieken. Tenslotte is ingegaan op twee gebeurtenissen in een ziekteperiode, die ten grondslag kunnen liggen aan het ontstaan van twee typen wachttijden. Stuurloze perioden doen zich voor, wanneer patienten hernieuwd doktersbezoek uitstellen; verwijzingswachtperioden kunnen ontstaan, wanneer patienten in of naar de tweede of derde lijn worden doorverwezen.

In schema 2.1 . zijn de belangrijkste literatuurbevindingen uit dit hoofdstuk weergegeven. 
Schema 2.1.

Literatuurbevindingen in verband met te bestuderen variabelen.

te bestuderen variabelen:

lange ziekteduren

stuurloze dagen

verwijzingswachtdagen

verwijzingen beinvloedende factoren:

- kenmerken van aandoening van verzuimers

- persoonskenmerken van verzuimers

- kenmerken werk van verzuimers

- kenmerken m.b.t. organisatie van de gezondheidszorg

- weinig gestructureerde samenwerking tussen behandelende en verzekerings/bedrijfsgeneeskundige sector

- "uitstelgedrag" van patiënten, samenhangend met persoonskenmerken en kenmerken van de aandoening

- ongelijk aanbod van gezondheidszorgvoorzieningen in tweede en derde echelon

- kenmerken van de aandoening van patiënten

- persoonskenmerken van patiënten

- aanbod van gezondheidszorgvoorzieningen in $1 \mathrm{e} t / \mathrm{m} 3 \mathrm{e}$ lijn (incl. afstand tot ziekenhuis)

- morbiditeit in verzorgingsgebied ( $\%$ bejaarden)

- (taak-)opvattingen van artsen 
HOOFDSTUK 3.

OPZET EN VERLOOP VAN HET ONDERZOEK.

3.1. Inleiding

In dit hoofdstuk wordt beschreven op welke wijze het onderzoek is opgezet en uitgevoerd. Ten eerste komt hierbij de omschrijving van de onderzoekspopulatie aan de orde. Vervolgens wordt behandeld, op welke manier het veldwerk van het onderzoek is uitgevoerd. Daarna worden de resultaten van het veldwerk beschreven en wordt de non-respons nader geanalyseerd. In de voorlaatste paragraaf worden dan nog enkele kenmerken van de respondenten beschreven. Een samenvatting sluit het hoofdstuk af.

3.2. De omschrijuing van de onderzoekspopulatie

In hoofdstuk 1 heeft men kunnen lezen, dat het z-Limburgse ziekteverzuimproject uit 3 onderdelen is opgebouwd. Respectievelijk gaat het om een organisatiestudie, een werknemersenquête en het hier gerapporteerde patiëntenonderzoek.

Een bijzonder kenmerk van het totale project is, dat de 3 onderzoeken betrekking hebben op een en dezelfde populatie. voor het patiëntenonderzoek betekent dit, dat alle respondenten -zieke werknemers- behoren tot het personeel van de 51 organisaties, die aan de organisatiestudie van Nijhuis \& soeters (1982) hebben deelgenomen. In feite is er hier sprake van een getrapte steekproeftrekking:

a. ten eerste is er een steekproef getrokken van 51 organisaties,

b. vervolgens is ex een nieuwe steekproef van zieke werknemers getrokken uit het bestand van langdurig zieken onder het personeel van deze 51 organisaties.

Met een beschrijving van de populatie en steekproef van het organisatie-onderzoek is de onderzoekspopulatie van deze patiëntenstudie daarom voor een belangrijk deel al gegeven: 
a a.

$\overline{\text { De } 51}$ onderzoekseenheden van de organisatiestudie zijn getrokken uit een populatie van bedrijwen en instellingen, die:

- uitsluitend in het Herstructureringsgebied $z$-Iimburg gevestigd zijn,

- uit alle takken van bedrijvigheid afkomstig kunnen zijn, en

- een minimale volledige personeelsbezetting van 50 werknemers (-sters) hebben (Nijhuis en Soeters, 1982).

De uit deze populatie getrokken steekproef van 51 organisaties omvat 26 industriële bedrijven en 25 instellingen uit de commerciële en niet-commerciële dienstverlening. Belangrijke clusters in deze steekproef worden gevormd door de nutsbedrijven (5), de gezondheidszorg (6), de metaalindustrie (9) en de bouwmaterialenindustrie (5). Per omvangscategorie is deze organisatiesteekproef goed verdeeld. $\operatorname{Er}$ is geen reden om aan te nemen, dat de steekproef op enigerlei wijze een specifieke selectie zou vormen van de totale onderzoekspopulatie. Voor meer details over de steekproeftrekking zij verwezen naar Nijhuis en Soeters (1982).

ad. b.

Het personeel van de 51 organisaties van de zojuist beschreven steekproef vormt de basispopulatie, de "population at risk", voor het hier gerapporteerde patiëntenonderzoek. Meer gegevens over de leeftijdsopbouw van deze basispopulatie kan men vinden in paragraaf 3.4. Het betreft een populatie van 13.266 mensen.

Uit deze "population at risk" is de onderzoekspopulatie van het hier verslagen patiëntenonderzoek gedestilleerd. Deze populatie kan als volgt worden omschreven: alle personeelsleden van de genoemde 51 organisaties, die zich gedurende het veldwerk van het organisatie-onderzoek (jan.-aug. 1981) voor een aaneengesloten periode van minstens 4 weken hebben ziekgemeld.

De reden, om het patiëntenonderzoek qua populatie-omschrijving zo te koppelen aan de al vaker genoemde organisatiestudie, is tweeërlei geweest. Ten eerste ls deze wijze van respondentenwerving -als het, zoals hier, gaat om zieke werknemers- op onderzoekstechnische en practische gronden gemakkelijker dan werving via andere kanalen. Ten tweede is het voor de probleemstelling van dit onderzoek van belang, 
om kenmerken van de organisaties, waax de patiënten in kwestie werkzaam zijn, in de analyse te kunnen betrekken.

Dat de respondenten van het patientenonderzoek 4 weken aaneengesloten ziek moesten $z i j n$, berust op de volgende argumenten. Ten eerste is de doelstelling van het onderzoek gerlcht op de langere ziekteduren. Die vormen immers op het gebied van ziekteverzuim het belangrijkste beleidsprobleem in Z-Limburg (Soeters, 1980a). Verder gaat het in dit verslag voor een belangrijk gedeelte on de interactie tussen patiënt en gezondheidszorg. Bij een ziekteduur van tenminste 4 weken is vrijwel altijd sprake van aandoeningen, die tot contact met het gezondheidszorgsysteem nopen. Tenslotte is geprobeerd zoveel mogelijk aansluiting te zoeken bij de procedures van het al eerder genoende onderzoek van Tordoir e.a. $(1978)$.

Voor alle volledigheid: bij de werving van respondenten is nog een andere selectie toegepast. Personeelsleden van de genoemde organisaties, die niet in Nederland woonden, kwamen niet in aanmerking voor het onderzoek. In de meeste gevallen zullen deze werknemers namelijk ook buiten het bereik van het Nederlandse gezondheidszorgsysteem vallen.

Samenvattend kan men zeggen, dat de populatie van het hier verslagen onderzoek bestaat uit werknemers in loondienst, die:

a. in Nederland woonachtig zijn.

b. uitsluitend werkzaam zijn bij organisaties, die gevestigd zijn in $\mathrm{z}$-Limburg,

c. werkzaam zijn bij in principe alle soorten bedrijven en instellingen, dus ook bij overheidsorganen, met meer dan 50 personeelsleden in dienst.

d. zich in de eerste 8 maanden van 1981 tenminste 4 weken aaneengesloten hebben ziekgemeld.

Verder is geen enkele selectie toegepast, met als gevolg, dat in dit onderzoek zowel mannen als vrouwen voorkomen, bultenlandse naast Nederlandse werknemers en eveneens alle mogelijke soorten functienivo's. Tot slot: alle mogelijke diagnoses met uitzondering van zwangerschap, kunnen in dit onderzoek vertegenwoordigd zijn. 
3.3. Uitvoering van het onderzoek

Het is duidelijk, dat de bedrijven en instellingen, die deelnamen an de organisatiestudie van Nijhuis soeters (1982), ook de "leveranciers" waren van de respondenten van het patiënten-onderzoek.

Bij de benadering van de organisaties voor deelname aan het organisatie-onderzoek is de werving van zileke personeelsleden voor het patiënten-onderzoek dan ook nadrukkelijk aan de orde gesteld. De opzet hierbij was, dat niet alleen de directie van de organisatie, maar ook de personeelsvertegenwoordiging zijn toestemming hiertoe moest verlenen. Juist de werving van zieke werknemers voor het patiëntenonderzoek heeft tenminste 3 organisaties ertoe gebracht, af te zien van deelname aan het totale project, ofschoon men wel aan het organisatie-onderzoek had willen meedoen. Deze laatste mogelijkheid-alleen deelname aan het organisatie-onderzoekwas door ons evenwel geblokkeerd. Voor meer details omtrent de benadering van de organisaties en het verloop van de deelname aan het volledige $\mathrm{RL}$-project leze men Nijhuis en Soeters (1982).

Hier volstaat de constatering, dat de namen van zieke werknemers pas aan de RL werden doorgegeven, na goedkeuring hiervan door zowel dixectie als personeelsvertegenwoordiging van de betrokken organisatie. De namen, alsmede de bijbehorende data van ziekmelding, werden vrijwel altijd aan ons gegeven door een functionaris van de afdeling Personeelszaken. Doorgaans was dit dezelfde functionaris, die ook geinterviewd werd voor het organisatie-onderzoek. In eerste instantie werden de namen doorgegeten na afloop van dat interview. Later gebeurde dit telefonisch, op elk tijdstip en zo vaak, als daar door ons om gevraagd werd. Het is dus niet zo geweest, dat ieder bedrijf of instelling automatisch de namen van de daarvoor in aanmerking komende personeelsleden aan ons doorgaf. Overigens werden op ons verzoek niet alleen de namen en adressen van de zieken aan ons doorgegeven, maar ook hun geslacht en leeftijd. Deze gegevens waren nodig in verband met de hierna nog te rapporteren non-response analyse.

zodra wij de beschikking hadden over de namen en adressen, stuurden wij een aankondigingsbrief naar de potentiële respondenten. Hierin stond in het kort de doelstelling van het 
onderzoek, alsmede de wijze, watrop wij a an de naam en het adxes van de betreffende persoon gekomen waren. verder stond ir deze brief vermeld, dat een vertegenwoordigster van de RI enkele dagen na verzending van de brief contact met de betrokkene zou opremen.

Met deze stap startte het veldwerk van het patiëntenonderzoek. Dit veldwerk is verricht door twee onderzoeksassistentes, beiden met jarenlange ervaring in de gezondheidssector. Later kregen $z j j$ nog ondersteuning van een student-assistent van de Rijksuniversiteit Limburg te Maastricht.

Hun eerste taak omvatte dus de benadexing van de potentiële respondenten, om na te gaan, of men voelde voor deelname aan het onderzoek. Indien dat het geval was, makten $z i j$ een afspraak voor een bezoek bij de respondent thuis. Wanneer de patient niet over een telefoon beschikte, legden zij een bezoek bij de potentiële respondent af.

ijidens het eerste bezoek werden de respondenten voor de eerste mal geinterviewd. Dit gebeurde aan de hand van een van tevoren geteste en gestandaardiseerde vragenlijst. In dit interview werden vragen gesteld over de ziektegeschiedenis, het werk van de respondent, alsmede over zijn of haar zilektebeleving. Vervolgens werd tijdens het eerste bezoek een inventarisatie gemaakt van de contacten, die de patiënt vanaf werkstaking tot dat moment met hulpverleners uit de gezondheidszorg had gehad. Per contact werd een tiental kenmerken genoteerd, waaronder de exacte datum, het specialisme van de betreffende hulpverlener en de initiator van het contact. Ook deze gegevens wexden verwerkt met behulp van gesandaardiseerde invulformuliexen.

De gegevensverzameling tot zover was dus retrospectief van ara, zoals meestal het geval is bij patientenonderzoek (McKlnlay, 1972). De rest van de gegevensverzameling verliep darentegen volgens de longitudinale methode. Dit verdere verloop hield in, dat de interviewster van de $\mathbb{R}$ met een zekere regelmat $(1-\mathrm{a}$-wekelijks) telefonisch kontakt met de respondent opnam. Op deze manier werden de nieuwe contacten van de patiènt met de gezondheidszorg geïnventariseexd. Bij de respondenten, die geen telefoon ter beschikking hadden, werden regelmatig bezoeken thuis afgelegd. Waar dit om sociale redenen of areigende communicatiestoornissen nodig werd geacht, werden ook andere respondenten thuis bezocht. Dit gebeurde zolang, totdat de ziektewet-periode van de respondent als beëindigd kon worden beschouwd. Wij hebben 
derhalve geen biomedisch herstelkriterium gebruikt. De Zlektewet-periode is beëindigd, wanneer er sprake is van:

a. werkhervatting (geheel of gedeeltelijk).

b. een beroepsprocedure of ontslag,

c. overgang maar de WAO of het Invaliditeitspensioen, of

a. overgang naar enigerlei vuT-regeling.

Opzet hierbij was, dat de registratieperiode bij elke respondent maximaal 1 kalenderjaar vanaf datum werkstaking zou kunnen beslaan. In die termijn moet per definitie de overgang naar de WAO gerealiseerd zijn; bovendien waren in dit onderzoek -opvallend genoeg- alle arbeidsongeschiktheidsgevallen van ambtenaren voor het Invaliditeitspensioen afgehandeld.

Wanneer volgens bovenstaande definitie het elnde van de registratieperiode bepaald was, makte de onderzoekster van de RL een afspraak voor het houden van een tweede interview bij de respondent thuis. In dit laatste interview werd uitvoerig ingegaan op de werkhervatting of WAO-intrede, waarbij ook het toekomstperspectief van de respondent binnen en/of buiten zijn werk aan de orde kwam. Hierna werd het onderzoek bij de respondenten als afgesloten beschouwd. Volgens deze procedure zijn in de periode januari $t / m$ augustus 1981,303 potentiële respondenten benaderd en is de onderzoeksperiode van de laatste respondent in meil 1982 beëindigd. De codering van de gegevens lag in de handen van dezelfde onderzoeksassistentes, die ook het veldwerk hadden verricht; hierbij werd de stelregel gebruikt, dat iedere onderzoeksassistente niet de gegevens van haar "eigen" respondenten zou coderen. De codeerfase, die grotendeels overlapte met de veldwerkfase, kon in juni 1982 worden afgerond.

Tenslotte een opmerking over de gevolgde longitudinale manier van dataverzamelen. Het gevaar is niet ondenkbaar, dat respondenten, die zich gedurende langere tijd geobserveerd weten, zich anders gedragen dan zij normal gesproken zouden doen. Dit verschijnsel is algemeen bekend als het Hawthorneeffect (Mayo, 1945). Nu is over het bestaan en de omvang van dit verschijnsel bij ons onderzoek niets vast te stellen. Het is een onvermijdelijk risico, dat wij hebben moeten accepteren; een andere wijze van dataverzameling, bijvoorbeeld met dossiers van artsen, moest gezien de grote diversiteit aan hulpverleners in de gezondheldszorg als volledig onwerkbaar van de hand worden gewezen (zie ook: Tordoir e.a., 
1978). Een volledig retrospectieve dataverzameling bij patiënten moest vanwege het beperkte geheugen, dat mensen nu eenmaal hebben, eveneens verworpen worden.

3.4. De resultaten van het velawerk

Van de 303 benaderde potentiële respondenten hebben uiteindelijk 213 patiënten aan het onderzoek meegedaan. Dit is een deelnemerspercentage van 70. Tabel 3.1 verschaft nadere informatie over de redenen van uitval.

Tabel 3.1 .

Deelname en (redenen van) uitval

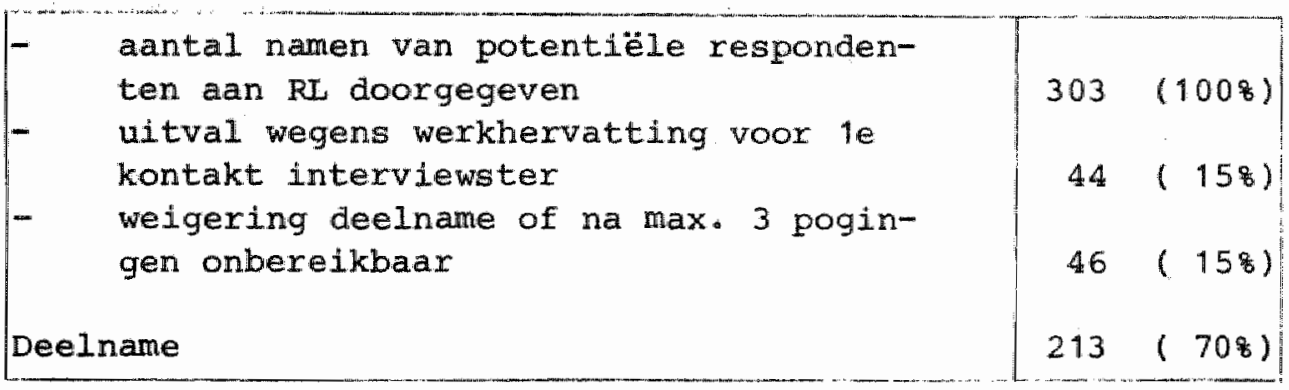

Deze tabel laat zien, dat $15 \%$ van de benaderde potentiële respondenten reeds hersteld was, voordat het onderzoek bij hen had kunnen beginnen. zij pasten op dat moment dus niet meex binnen de omschreven onderzoekspopulatie. In feite betekent dit, dat niet 303, maar 259 (zijnde 303-44) voor het onderzoek in aanmerking komende potentiële respondenten $z i j n$ benaderd. Dit levert dan een responsepercentage van 82 $(=213 / 259)$ op.

Dit percentage kan vergeleken worden met de response-resultaten van een viertal andere Nederlandse onderzoeken bij zieke werknemers; bij deze berekening zijn voortijdige werkhervatters e.d. buiten beschouwing gelaten:

- Niersma, 1979, response 86\%

- Tordoir e.a., 1978; response 858

- Merens-Riedstra, 1981; response voor verschillende steekproeven variërend van $85 \%$ tot $89 \%$

- de Jonge e.a., 1981; response na benaderingsprocedure met actieve machtiging: 488 . 
In verhouding tot deze percentages is de response van ors onderzoek bevredigend te noemen. Dat het veldwerk een gunstig verloop heeft gekend, blijkt eens te meer uit een vergelijking van een aantal persoonskenmerken van de weigeraars met die van de uiteindelijke deelnemers.*

De respondenten onderscheiden zich niet significant van de weigeraars in leeftijd, geslacht en urbanisatiegraad van de woonplaats (zie tabellen $3.2 \mathrm{t} / \mathrm{m} 3.5$ in de bijlage). Alleen blijken werknemers uit de industriële sector iets vaker geweigerd te hebben dan personeelsleden van niet-industriele instellingen. Dit verschil is overigens niet significant op 5 - nivo.

Het onderscheid industrieel versus niet-industrieel levert trouwens meer verschillen op. Zo blijkt $66 \%$ van de aan ons doorgegeven namen van potentiële respondenten in de industriële sector werkzaam te zijn, terwijl slechts $57 \%$ van de "population at risk" in de industrie werkzaam is. Uiteindelijk behoort 64 van de deelnemende respondenten tot de industrie, waarmee deze sector dus oververtegenwoordigd is, zij het niet in extreme mate.

De reden van deze oververtegenwoordiging is ongetwijfeld gelegen in het feit, dat in industriẻle bedrijven meer langdurig ziekteverzuim voorkomt dan in niet-inaustriële organisaties. Voor het airect-uitvoerend mannelijk personeel bijvoorbeeld bedraagt de gemiddelde ziekteduur in industriële bedrijven uit de "population at risk" 23,5 dagen, terwijl dit in de niet-industriële organisaties 16,3 dagen is $(F=9.0, p<0.01)$. Op grond hiervan kan men veronderstelien, dat de industrièle bedrijven over meer aanbod van langdurlge ziektegevalien beschikken en derhalve ook meer potentiële respondenten bij ons hebben kunnen aanmelden.

Dan is er nog een ander punt. Zoals gezegd, omvat de populatie van dit onderzoek werknemers, die zich minimal 4 weken aaneengesloten ziek hebben gemeld. Onder meer wegens het tijasverloop tussen het ontvangen van namen en de benadering van de potentiële respondenten, is in dit criterlum ver-

Wij hebben helaas niet de beschikking over gegevens over het ziekteverzuim van de weigeraars in de periode voorafgaande thet onderzoek. Deze vergelijking kunnen wij dus niet maken; dit moet - gelet op de bevinding van Dijkstra (1981)- als een tekortkoming worden aangemerkt. 
schuiving opgetreden.

Dit heeft tot gevolg gehad, dat-gemiddeld over de gehele steekproef bekeken- het onderzoek blj de respondenten pas in het begin van de $6 \mathrm{e}$ week van hun ziekteperiode gestart is. Een soortgelijk effect heeft zich overigens ook voorgedaan in het onderzoek van Tordoir e.a. (1978), waar de aanvankelijke selectie-eis van 4 weken ziekte verschoven is naax 5 tot 6 weken ziekte. Op dit punt blijft onze steekproef dus vrij goed vergelijkbaar met de onderzoeksgroep van Tordoix C...s.

Resteert de laatste vraag van deze paragraaf: is onze steekproef van langdurig zieke werknemers, die zich niet onderscheldt van de weigeraars, representatief voor alle langdurig zieke werknemers in Nederland? Deze vraag lat zich moellijk beantwoorden, niet in de laatste plaats, omdat precies vergelijkbare statistieken niet beschikbaar zijn. $0 . a_{\text {. }}$ zitten we met het probleem, dat in onze steekproef ook ziektegevallen voorkomen, die bij aanvang van de dataverzameling korter of langer dan 6 weken duurden. Bij landelijke statistieken wordt vanzelfsprekend een categorie-indeling met vaste grenzen aangehouden. Met inachtneming van deze complicatie derhalve vergelijken wij nu de leeftijdsopbouw van onze steekproef met een grote landelijke steekproef van ziektegevallen, die langer dan 6 weken duren. Deze gegevens zijn berekend op basis van de CCOZ-statistiek voor het jaar 1980; zij hebben betrekking op 14.753 personeelsleden; dit zijn zowel mannen als vrouwen, afkomstig uit alle takken van bedrijvigheid, incl. de overheid (Kruidenier, 1982). 
Tabel 3.6.

Leeftijdsopbouw van steekproef en populatiebestand van het Z-Limburgse onderzoek en de landelijke representative CCOZstatistiek.

\begin{tabular}{|c|c|c|c|}
\hline Zuid-Limburg & $\begin{array}{l}\text { steekproef } \\
\text { langdurig } \\
\text { zieken } \\
\text { (>6 weken) } \\
\text { (1) }\end{array}$ & $\begin{array}{l}\text { populatie- } \\
\text { "at risk" } \\
\text { van de } 51 \\
\text { organisat. } \\
\text { (2) }\end{array}$ & $\begin{array}{c}(3) \\
(1-2) \\
\end{array}$ \\
\hline $16 t / m 25$ jaax & 178 & 218 & -48 \\
\hline $26 \mathrm{t} / \mathrm{m} 35$ jaar & 29 영 & 298 & 08 \\
\hline $36 \mathrm{t} / \mathrm{m} 45$ jaar & 268 & 258 & 18 \\
\hline $46 \mathrm{t} / \mathrm{m} 55$ jaar & 198 & 198 & 08 \\
\hline $56 \mathrm{t} / \mathrm{m} 65$ jaar & 98 & 68 & 38 \\
\hline 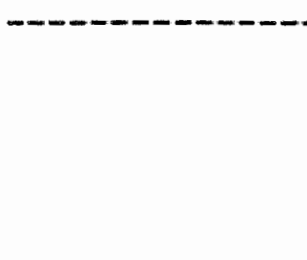 & $\begin{array}{l}\text { Ccoz-cate- } \\
\text { gorie der } \\
\text { langdurig } \\
\text { zieken } \\
\text { (>6 weken) }\end{array}$ & $\begin{array}{l}\text { volledige } \\
\text { CCOZ-statis } \\
\text { tiek }\end{array}$ & \\
\hline Nederland & $(4)$ & (5) & $\begin{array}{c}(6) \\
(4-5)\end{array}$ \\
\hline $16 \mathrm{t} / \mathrm{m} 25$ jaar & 98 & 168 & -78 \\
\hline $26 \mathrm{t} / \mathrm{m} 35$ jaar & 268 & 288 & -28 \\
\hline $36 \mathrm{t} / \mathrm{m} 45$ jaar & 268 & 258 & 18 \\
\hline $46 \mathrm{t} / \mathrm{m} 55$ jaar & 248 & 208 & 48 \\
\hline $56 \mathrm{t} / \mathrm{m} 65$ jaar & $15 \%$ & 118 & 48 \\
\hline
\end{tabular}

Tabel 3.6 laat zien, dat onze z-Limburgse steekproef van langdurig zieken een stuk jonger is dan de steekproef geldend voor heel Nederland (vgl. kolommen 1 en 4 ). Maar bij deze vergelijking moet verdisconteerd worden, dat er forse populatieverschillen tussen de beide regionale gebieden bestaan (kolommen 2 en 5). Het percentage 50-plussers, dat nog tot de actieve beroepsbevolking behoort, is in ( $\mathrm{z}-$ - I L imburg aanmerkelijk kleiner dan in geheel Nederland (soeters. 1980a). Dit is het gevolg van de vrij massale WAO-instroom in $\mathrm{Z}$-Iimburg in het verleden.

Om de effecten van dit populatieverschil te elimineren, zijn de kolommen 3 en 6 berekend. Op basis van belde kolormen kan een betere vergelijking gemaakt worden van de leeftijdsopbouw van resp. de Z-Limburgse en Nederlandse steekproef. De- 
ze vergelijking nu blijft de indruk bevestigen, dat de $z$ Limburgse steekproef van langdurig zieke werknemers gemiddeld (lets) jonger is dan de Nederlandse steekproef. Onder het eerder vermelde voorbehoud zou men -ook al in aansluiting op eerdere bevindingen (Soeters, 1980a)- kunnen concluderen, dat het langdurig ziekteverzuim in $\mathrm{z}$-Limburg gemiddeld vaker op jongere leeftija begint dan in geheel Nederland*. Dit makt dit onderzoek voor wat betreft zijn beschrijvende resultaten niet zonder neer generaliseerbaar voor geheel Nederland. Wanneer het evenwel gaat om verklarende analyses, heeft dit generaliseringsprobleem veel minder gewicht (Philipsen, 1969b).

3.5. Enkele kenmerken van de respondenten

De steekproef bestaat uiteindelijk uit 213 personen, die a1len tweemal zijn geinterviewd. In deze paragraaf beschrijven wij-bij wijze van kennismaking- enkele basiskenmerken van hen.

zoals uit de vorige paragraaf bleek, zijn de respondenten uit deze steekproef verhoudingsgewijze jong: 178 is jonger dan 26 jaar en slechts 98 is oudex dan 55 jaar. De gemiddelde leeftijd bedraagt 38 jaar. Er zijn 30 (oftewel 148) vrouwen in de steekproef.

Het merendeel $(848)$ is gehuwd, minder dan 38 is oolt gescheiden. Bijna 948 heeft de Nederlandse nationaliteit, terwijl bijna 5 afkomstig is uit het Middellandse-zee-gebied. Bljna $2 / 3$ gedeelte van alle ondervraagden woont in stedelijke gemeenten, zoals Maastricht, Heerlen en Sittard. De rest woont vrijwel uitsluitend op het verstedelijkte platteland; begrijpelijk, aangezien echte plattelandsgemeenten in $\mathrm{z}$-Limburg vrijwel niet voorkomen. Qua opleiding heeft ruim 428 van de ondervraagden alleen het lager onderwijs of lager onderwijs plus enkele jaren voortgezet onderwijs genoten. Bijna $1 / 3$ gedeelte heeft het lager

andere vergelijkingen dan voor leeftijd hebben wij niet gemaakt, omdat de indelingen (met name voor functie of beroep) van de beide bestanden niet goed op elkaar passen. 
beroepsonderwijs voltooid, terwijl nog eens 128 een voortgezette algemene opleiding heeft afgesloten. De rest zit op een hoger opleidingsnivo. Ruim een kwart van alle ondervraagden -tenslotte- is tenminste én keer werkloos geweest.

\subsection{Samenvatting}

In dit hoofdstuk is ten eerste een beschrijving gegeven van de onderzoekspopulatie. Deze populatie bestaat uit wexknemers (neemsters) in loondienst, die:

a. in Nederland woonachtig zijn,

b. uitsluitend werkzaam zijn bij bedrijven en instellingen, die gevestigd zijn in het Herstructureringsgebied z-Limburg,

c. werkzaam zijn bij in principe alle soorten bedrijven en instellingen, incl. overheidsorganen, met meer dan 50 personeelsleden in dienst,

d. zich in de eerste 8 maanden van 1981 tenminste 4 weken aaneengesloten hebben ziekgemeld.

Ten tweede is vermeld, dat de gegevensverzameling van het onderzoek deels retrospectief, deels longitudinaal van aard geweest is. Alle respondenten zijn tenminste twee keer thuis bezocht en geinterviewd door een van de drie veldonderzoekers/-sters. Naast een tweetal interviews bestond de dataverzameling uit een gestandaardiseerde registratie van de contacten, die de respondenten met hulpverleners uit de gezondheidszorg hadden gehad. Deze registratie bestreek de periode van datum ziekmelding tot einde van de ziektewetperiode.

De namen en adressen van in aanmerking komende respondenten werden -met goedkeuring van de betreffende directies en organen van personeelsvertegenwoordiging- ter beschikking gesteld door de bedrijuen en instellingen, die hadden deelgenomen aan het organisatie-onderzoek van wijhuis s soeters, 1982 .

Met betrekking tot het veldwerk is in dit hoofdstuk vastgesteld, dat het een betrekkelijk gunstig verloop heeft gekend. De veldwerkperiode kon namelijk worden afgesloten met eer responspercentage van 82 , terwijl de welgeraars naar 
leeftijd, geslacht en urbanisatiegraad van de woonplaats nilet afweken van de uiteindelijke respondenten. Ten opzichte van de omschreven onderzoekspopulatie kon de in dit onderzoek bereikte steekproef van 213 langdurig zieke werknemers (-sters) als voldoende representatief beschouwd worden. Ten opzichte van een Nederlandse steekproef van personeelsleden, die langer dan 6 weken ziek zijn, vormt de steekproef uit dit onderzoek geen identieke afspiegeling. De z-Limburgse steekproef is gemiddeld namelijk lets jonger. Dit impliceert, dat vooral de beschrijvende gegevens van dit onderzoek niet zonder meer geëxtrapoleerd kunnen worden naar de situatie in geheel Nederland. 
HOOFDSTUK 4.

DE BEHANDELING.

4. 1. Inleiding

In dit eerste hoofdstuk met onderzoeksresultaten stellen wij een van de kernvragen uit dit onderzoek: welke zijn de ziekteduurverlengende effekten, die uit de interactie tussen patiënt en gezondheidszorg ontstaan en hoe groot zijn deze? Meer specifiek richten wij ons hier op organisatorische aspecten van de gezondheidszorg en niet op inhoudelijke kanten van de medische dienstverlening.

Er wordt derhalve geen poging gedaan om het rendement van medische handelingen te bepalen, waarbij de verlengde ziekteduur afgewogen zou worden tegen de vergroting van de herstelkansen. Zo een dergelijke onderneming al zou kunnen slagen, dan toch niet op deze plaats.

Hier is een andere kwestie aan de orde. In hoofdstuk 2 is gesignaleerd, dat de diverse schijven, zo men wil behandelstations, in de gezondheidszorg niet optimaal op elkaar zijn afgestema. In complexe organisatorische systemen, zoals de gezondheldszorg, kunnen processen van schalvergroting en specialisatie leiden tot gebrekkige planning en coördinatie en derhalve tot niet-optimale productiesnelheden. Dit kan onder meer tot uiting komen in het ontstaan van voorraadvorming en wachttijden (de sitter, 1981). In de gezondheidszorg bestaat dit organisatieprobleem net zo goed als in veel andere productiesystemen (zie uitgebrelder hierover: hoofdstuk 2).

Om meer inzicht te krijgen in de gevolgen van dit vraagstuk, volgt in dit hoofdstuk een beschrijving van het behandelingsproces, dat de respondenten van dit onderzoek tijdens hun ziekteperiode hebben meegemaakt. Deze beschrijving -representatief voor z-Limburg- zullen wij op essentiele punten vergelijken met het onderzoek van Tordoir e.a. (1978); dat onderzoek heeft -zoals gezegd- betrekking op de situatie in de Randstad, in de jaren 1974/1975.

Deze vergelijking maken $w j$, om een basisveronderstelling uit ons vooronderzoek te toetsen. Deze veronderstelling 
hield in, dat de langere ziekteduren in z-Iimburg gedeelte$11 j k$ toe te schrijven zouden zijn aan langere wachttijden als gevolg van de kwantitatlef minder goed ontwikkelde gezondheldszorgvoorzieningen (Soeters, 1980a en b).

In deze veronderstelling wordt slechts éen van de vele determinanten van de patiënt-gezondheldszorg-interactie benadrukt. Immers, ook kenmerken van de patiënten zelf beInvloeden de wijze, waarop men in de gezondheldszorg terecht komt en daarin behandeld wordt (Mechanic, 1978). Om nu het effect van de gezondheidszorgvoorzieningen te kunnen toetsen, is het daarom ook van belang om te weten of de respondenten uit dit onderzoek afwijken van de onderzoekspersonen van Tordoli c.s.

In dit verband moet men zich ten eerste realiseren, dat de studie van Tordolr c.s. alleen betrekking heeft op GAK-verzekerden; in onze z-Limburgse steekproef zijn daarentegen ook andere verzekerden opgenomen (ambtenaren in de $z$ in van Pensioenwet* en werknemers, die verzekerd $z i j n$ bij zelf-administrerende Bedrijfsverenigingen). Om deze reden zal een aantal cruciale -maar niet allel-gegevens uitsluitend voor de GAK-verzekerden in de z-Iimburgse steekproef berekend worden.

Vervolgens is het dan de vraag, of de GAK-verzekerden uit onze steekproef zich op belangrijke kenmerken onderscheiden van de respondenten van Tordoir e.a. (1978). Uit de in de bijlagen $4.1 \mathrm{t} / \mathrm{m} 4.4$. opgenomen tabellen kan men hieromtrent het volgende opmaken. De z-Limburgse GAK-verzekerden zijn significant vaker van het mannelijk geslacht en zijn gemiddeld ook jonger. Verder zijn zij ook lets vaker verplicht verzekerd via het zlekenfonds. Deze steekproefverschillen zijn waarschijniljk goeddeels terug te voeren op populatieverschillen. Voor de gemiddeld jongere leeftijd van de $z-$ IImburgse beroepsbevolking zij verwezen naar soeters $(1980$ a). Verder is in $\mathrm{z}-\mathrm{L}$ imburg de participatie van vrouwen aan het arbeldsproces lets geringer dan in geheel Nederland (Et11, 1980, Perspectievennota z-Limburg, 1978). Tenslotte ligt het opleidingsnivo van de $\mathrm{z}$-Limburgse beroepsbevolking lager dan elders in Nederland (Perspectievennota Z-Limburg, 1978), deze omstandigheid is vermoedelijk verantwoordelijk 
voor een gemiddeld iets lager salarisnivo en komt tot uiting in een iets groter aantal verplicht verzekerden in onze steekproef in vergelijking met die ult de Randstad.

Met inachtneming van deze -bescheiden- verschillen gaan wij nu over tot de presentatie van de gegevens. In paragraaf 4.2 zal allereerst een overzicht gegeven worden van de aandoening, de ziektegeschiedenis en het begin van de ziekteperiode. Vervolgens worden in paragraaf 4.3 de contacten met de gezondheidszorg tijdens de behandeling beschreven. In de daaropvolgende paragraaf komen dan meer inhoudelijke aspecten van deze contacten aan de orde, alsmede het oordeel van de patiënten over die contacten. Vervolgens komt de kern van dit hoofdstuk in beeld, te weten de wachttijden (paragraaf 4.5). Daarna volgt een interpretatie van alle voorafgaande bevindingen in paragraaf 4.6. Een samenvatting van de belangrijkste bevindingen sluit daarna het hoofdstuk af (paragraaf 4.7 ).

4.2. De patiënten en het begin van hun ziekte

Een van de belangrijkste karakteristieken, zo niet de belangrijkste, waarmee men patiënten kan beschrijven, is de aard van hun aandoening, met andere woorden hun diagnose. Deze hebben wij voor onze steekproef vastgesteld op basis van de klachten, die de onderzoekspersonen hadden opgegeven; bij eventuele onduidelijkheden zijn wij bovendien afgegaan op het type artsen of specialisten, dat men tijdens de onderzoeksperiode geconsulteerd heeft. Een en ander hebben wij gedaan in samenspraak met een arts-medewerker van de capaciteitsgroep Huisartsgeneeskunde van de Rijksuniversiteit Limburg; bij twijfelgevallen had deze arts het laatste woord. Deze door ons gevolgde diagnose-procedure heeft een zwakke, maar ook een sterke kant. Het is een duidelijk minpunt, dat de diagnose niet is vastgesteld in een direkt arts-patiëntcontact. Daar staat tegenover, dat onze procedure wel tot een consistente beoordeling heeft geleid; onze diagnose-indeling wordt immers niet verstoord door inter-arts-variabiliteit (zie bijv. Gerritsma en Smal, 1982).

voor de indeling hebben wij de gebruikelijke 16 diagnose- 


\section{Figuur 1}

Diagnoseverdelingen van de onderzoeksgroepen in Z-Limburg en de Randstad

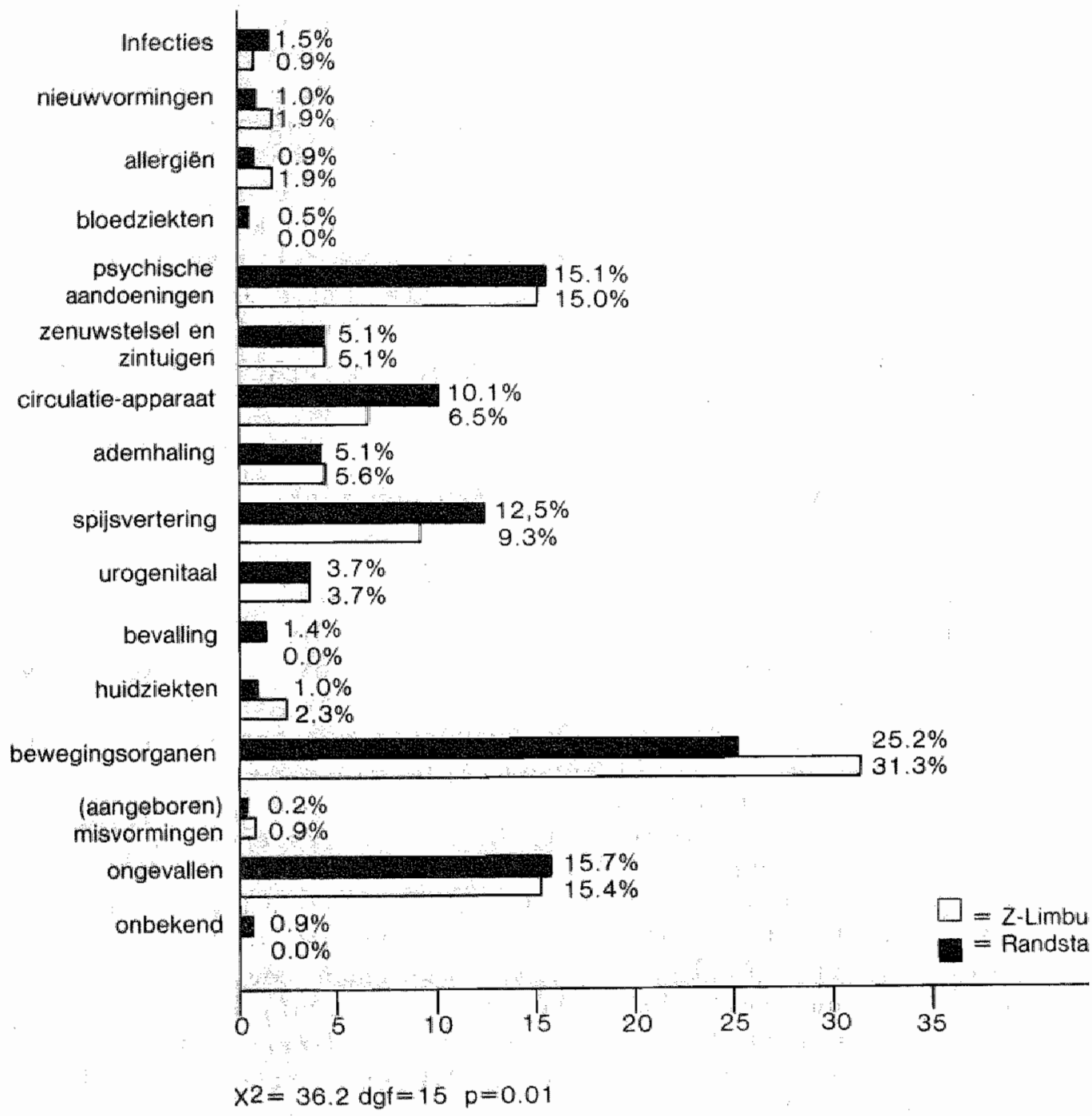


groepen * aangehouden. Het resultaat hiervan is weergegeven in figuux 1. Hierbij is een vergelijking gemaakt met de diagnoseverdeling van de onderzoeksgroep van Tordoix c.s. (1978).

De eerste conclusie op grond van deze figuur is niet anders dan gebruikelijk (bijv. de Jong e.a., 1981): 5 diagnosegroepen zijn voor beide steekproeven in kwantitatief opzicht belangrijk, te weten de ziekten van de bewegingsorganen, de ongevallen, de psychische aandoeningen en de ziekten wan het spijsverteringsstelsel en het circulatie-apparaat. Respectievelijk 778 (Z-Limburgse steekproef) en 78\% (Randstad) van de respondenten zijn in een van deze 5 diagnosegroepen onder te brengen. Hiermee komen de beide steekproeven niet alleen goed met elkaar overeen, maar ook met de normale ziekte- en arbeidsongeschiktheidsstatistieken (bv. GMD-jaarverslagen en de Jong e.a., 1981).

Dat neemt niet weg, dat er binnen deze 5 diagnosegroepen belangrijke verschilien bestaan tussen de $\mathrm{z}$-Limburgse en de Randstedelijke onderzoeksgroep. Ten aanzien van de diagnosen "ongevallen" en "psychosen" zijn er geen verschillen van enige betekenis. Daarentegen blijken de aandoeningen van de bewegingsorganen in de Z-Limburgse steekproef vaker voor te komen dan bij het onderzoek van Tordoir: 318 versus 258. Daar staat dan tegenover, dat de onderzoekspersonen uit de Randstad vakex aandoeningen van het circulatie-apparaat en het spijsverteringsstelsel hebben. Waaraan deze verschilien te wijten zijn, is niet duidelijk. Mogelijk vormt de gemiddeld jongere leeftijdsopbouw van de $\mathrm{z}$-Limburgse steekproef een (gedeeltelijke) verklaring voor dit verschil in diagnosen. Met name het geringe aantal aandoeningen aan het circulatie-apparaat in de z-Iimburgse steekproef is verrassend, gelet op de ook onlangs weer vastgestelde Limburgse oversterfte aan hartziekten (Hoogendoorn, 1982). Het is mogelijk, dat mensen met een hartziekte in Limburg sneller WAOuitkeringsgerechtigd worden. Dit is denkbaar vanwege het feit, dat de $z$-Limburgse respondenten met een hartziekte vaker dan bij andere diagnosen geen vroeger verzuim voor dezelfde aandoening hebben gehad. Volgens deze redenering zouden dan in het Randstadonderzoek relatief meer recidieve 
hartaandoeningen aanwezig zijn. overigens is dit laatste door ons niet te toetsen.

De in dit onderzoek geregistreerde diagnosen gaan overigens soms vergezeld van andere aandoeningen: 218 van de respondenten geeft an een nevenaandoening te hebben (Randstad: 158). Verder hebben de aandoeningen vaak een verleden: bijna de helft (488) van de respondenten wit dit onderzoek heeft voor dezelfde aandoening al eens eerder verzuimd; het merendeel hiervan (818) heeft plaatsgevonden in de twee jaar voorafgaande aan de datum van de ziekmelding. Dit beeld komt overeen met het onderzoek uit de Randstad (resp. $45 \%$ en 858).

Het recidiverend karakter van veel aandoeningen blijkt ook uit het felt, dat 27 van de onderzoekspersonen in de 2 jaar voor werkstaking met dezelfde klachten al eens een specialist heeft geconsulteerd. Voornamelijk waren dit orthopedische chirurgen, internisten, neurologen en longartsen. Tabel 4.5 geeft een verdeling van degenen, die voor dezelfde klachten al eens eerder verzuimd dan wel een specialist geconsulteerd hebben.

Tabel 4.5.

Vroeger verzuim en specialistische behandeling voor dezelfde klachten als tijdens onderzoeksperiode.

\begin{tabular}{|l|rrr|l|}
\hline vroegex verzuim & \multicolumn{4}{|l|}{ vroeger consult bij specialist(en) } \\
& ja & nee & \multicolumn{1}{c|}{ total } \\
\hline ja & $51(508)$ & $51(508)$ & 102 \\
nee & 6 & $(68)$ & $105(948)$ & 111 \\
total & $57(278)$ & $156(738)$ & 213 \\
\hline
\end{tabular}

$x^{2}=54,9, p=0.00$

Het blifkt, dat slechts $498(=105 / 213)$ van de respondenten, althans voor wat de in het onderzoek geregistreerde aandoening betreft, geen ziektegeschiedenis kent (Randstad: $46 \%$ ). Wanneer men hiervan nog degenen aftrekt, die op het moment van ziekmelding al onder behandeling van een huisarts waren, resteert slechts een percentage van 39 (Randstad: ook 39\%). Deze personen zijn dus aan hun ziekteperiode begonnen, zonder dat $z i j$ in het recente verleden ooit voor deze aandoening de patiëntenrol hebben aangenomen. 
Overigens was 43 van de respondenten op de dag van de ziektemelding al onder behandeling van een arts (huisarts: $30 \%$. specialist: 248) Dit percentage is gelijk aan het Randstadonderzoek.

Tot zover het verleden van de andoening. Hiermee zijn wij nu toegekomen aan het voor ziekteverzuim "officlële" begin van de ziekteperiode, te weten de ziekmelding of werkstaking.

Welke hulpverlener als eerste na de ziekmelaing geconsulteerd wordt, staat vermeld in tabel 4.6. Wederom is vergeleken met het Randstad-onderzoek.

Tabe1 4.6.

Specificatie van eerste consult na ziektemelding in Z-Iimburg en de Randstad.

\begin{tabular}{|l|rrr|c|}
\hline & Z-Limburg & Randstad & Totaal \\
\hline 1. & huisarts & $142(678)$ & $612(718)$ & 754 \\
2. Specialist- & $32(15 \%)$ & $138(168)$ & 170 \\
poliklinisch & $21(108)$ & $69(88)$ & 90 \\
opname ziekenhuis & verzekerings- & $11(58)$ & $38(48)$ & 49 \\
geneeskundige & $7(38)$ & $5(18)$ & 12 \\
bedrijfsarts & $\mathrm{N}=213(1008) \mathrm{N}=862(1008)$ & $\mathrm{N}=1075$ \\
\hline
\end{tabular}

$x^{2}=12,5 ; \mathrm{p}<0.05$

Net zoals elders (suchman, 1965), wordt de huisarts in het begin van de verzuimperiode verreweg het meest geconsulteerd, al gebeurt dit in het Randstad-onderzoek lets vakex dan in de $z$-Iimburgse steekproef. In beide onderzoeken vindt het eerste consult in een kwart van de gevallen bij de specialist plaats; hierbij komen in beide steekproeven de polikilnische consulten wat vaker voor dan de ziekenhuisopnames. verder blijkt in de $z$-Limburgse steekproef iets vaker de bedrijfsarts (BA) als eerste geconsulteerd te zijn.

Een volgende vraag betreft het tijasverloop tussen de datum van de ziektemelding en de datum van het eerste medisch consult. Dit tijdsverloop vormt de eerste potentiële bron van vertraging in het behandelingsproces. Hoe groot deze vertra- 
ging in respectievelijk de Randstad en $Z$-Limburg is geweest, vermeldt tabel 4,7 .

De meest in het oog springende bevinding is, dat de $z-L$ imburgse onderzoekspersonen gemiddeld sneller in contact treden met vertegenwoordigers van de gezondheidszorg dan de patlênten uit het Randstad-onderzoek 10.5 versus 1.5 werkdag na zlektemelding). Dit verschijnsel is ook nog op een andere manier an te tonen: $81 \%$ van de $z$-Limburgse respondenten meldt zich op de dag van werkstaking bij een medicus, terwijl dit percentage voor de Randstad-steekproef slechts 65 bedraagt. Alle respondenten op 28 na uit het zLimburgse onderzoek hebben zich binnen 1 week onder behandeling van de gezondheidszorg gesteld; in het Randstad-onderzoek moest op dat moment 78 zulks nog doen. Een verklaring voor deze verschillen laten wij op deze plaats achterwege. Voor een meer algemene interpretatie van de verschillen tussen het $\mathrm{z}-\mathrm{Lim}$ burgse en het Randstad-onderzoek verwijzen wij naar paragraaf 4.6. Hier beperken wij ons vooralsnog tot de cijfers en met name die uit tabel 4.7 .

Degenen, die tevoren al eerder onder behandeling waren voor de aandoening in kwestie en die op eigen initiatief het werk gestaakt hebben, hebben gemiddeld het langst gewacht met het eerste bezoek aan de medicus. In het z-Limburgse bestand is dit niet anders dan in de Randstad-steekproef. Een algemene verklaring hiervoor is, dat $z i j$ voor de ziekmelding al een afspraak met hun behandelend arts hadden en deze afspraak niet konden of probeerden te vervroegen. Een relatief lang tijdsverloop tussen ziekmelding en eerste consult ontstat ook, wanneer de patiënt niet onder behandeling is en op eigen initiatief het werk gestaakt heeft. Wanneer de arts daarentegen tot ziekmelding heeft geadviseerd, is dit tijdsverloop vanzelfsprekend zo goed als nihil. In dat geval ontstaat immers alleen uitstel, wanneer de axts al in een eerder stadium heeft aanbevolen het werk te staken bij een eventuele verergering van de klachten of symptomen. Dit is in de z-Iimburgse steekproef in totaal bij slechts 2 personen gebeura.

Een laatste bevinding uit tabel 4.7 betreft het feit, dat 408 van de $z$-Limburgse respondenten (dit is 49 in situatie 1 +37 in sltuatie $3=86$ respondenten) zich niet heeft ziekgemeld op grond van een aanwijzing of uitlating van een arts (Randstad: $34 \%$ ). Van dit aantal $(N=86)$ hebben zich 33 res- 


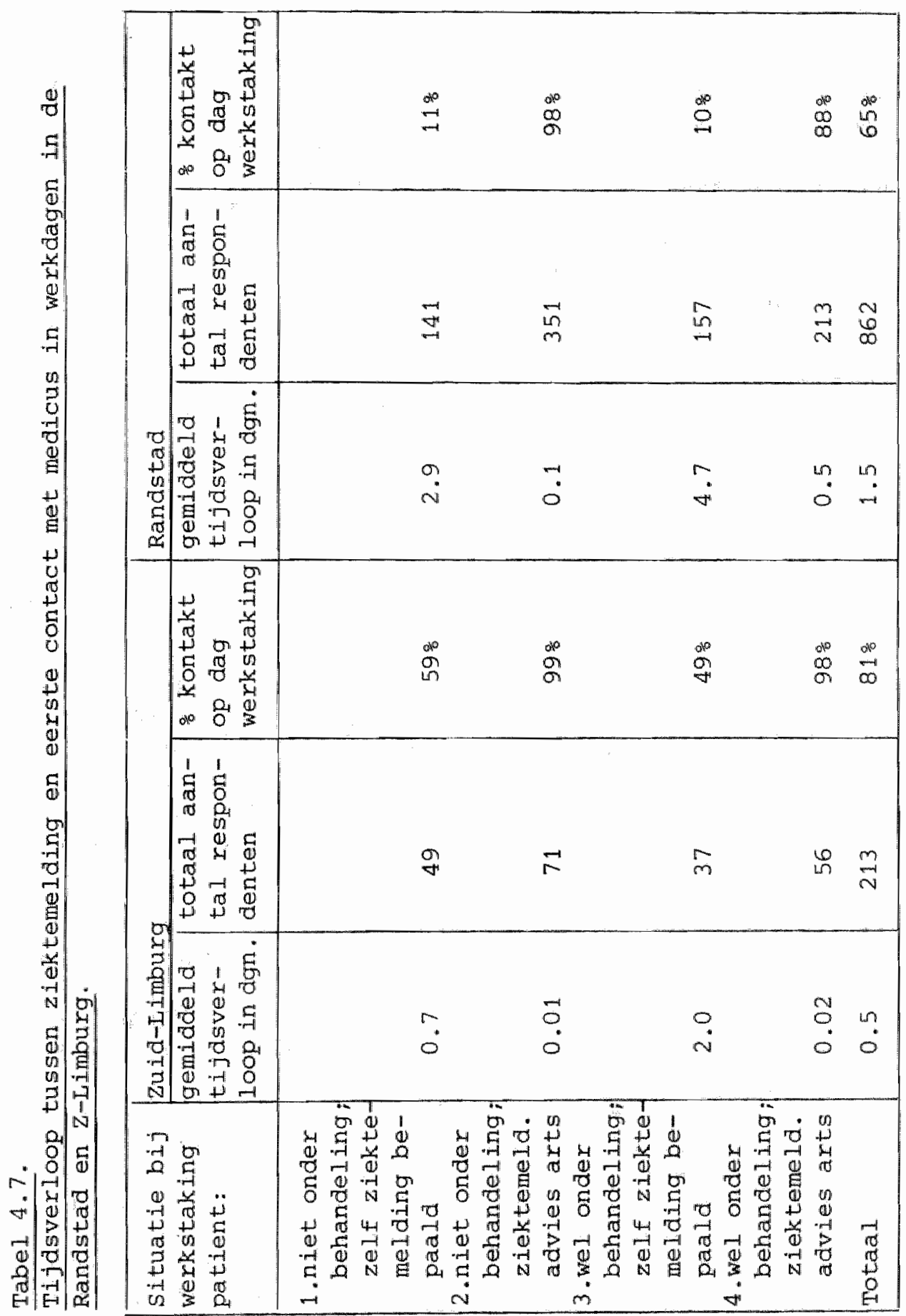


pondenten ( $\mathrm{d} .1 .=39 \%$ ) toch laten leiden door andermans oordeel, namelijk 22 (26\%) door het oordeel van de partner of een nabij familielid en 11 (13\%) door het oordeel van collega's. Lekenadvisering als deze is niet ongebruikelijk bij het nemen van stappen in de richting van de patiëntenrol (bv. Suchman, 1965; stimsom en Webb, 1975; Mootz, 1981). Tot slot van deze paragraaf over het begin van de ziekteperioden aandacht voor de directe aanleiding tot de ziektemelding: in de overgrote meerderheld van de gevallen ( $89 \%$ ) was dit -niet vexrassend- de aard van de aandoening; toch heeft voor 17 respondenten ( 88 ) de negatieve arbeldssituatie (in de meest rulme zin van het woord) de doorslag gegeven, om juist op die dag te gaan verzuimen.

4.3. De contacten met de gezondheidszorg

In deze paragraaf wordt een beschrijving gegeven van de contacten, die de onderzoekspersonen tijdens hun ziekteperiode met vertegenwoordigers uit de gezondheidszorg hebben gehad. opnleuw wordt een vergelijking gemaakt met Tordoir (1978) en met de aanvullende verslaggeving van het Randstad-onderzoek door van der Klaauw (1979). Deze vergelijking kan veilig gemaakt worden, aangezien de gemiddelde ziekteduur in beide onderzoeken nagenoeg even lang is: in de z-Limburgse steekproef 79 en in het Randstad-bestand 81 werkdagen. Bovendien is het percentage uiteindelijke niet-werkhervatters in beide onderzoeken nagenoeg even hoog (zie verder hierover: hoofdstuk 5).

De contacten zijn cijfermatig weergegeven in de overzichtstabel. 4.8.

Een eerste belangrijke conclusie betreft de hoge medische consumptie die de respondenten van beide onderzoeken aan de dag leggen. Gemiddeld meer dan een keer per maand consulteert een langduxig zieke werknemer de huisarts. Ter vergelijking: Adrlaanse e.a. vonden in 1981 onder een normale bevolkingssteekproef een gemiddelde consultfrequentle bij hulsarts én specialist van 2.9 keer per jaar. Verder is niet minder dan 728 van de respondenten uit de $z$-Limburgse steekproef ooit tijdens zijn ziekteperiode verwezen; ook dit percentage is zeer hoog in vergelijking met normale verwijscijfers voor zlekenfondsverzekerden (vgl. voor soortgelijke re- 


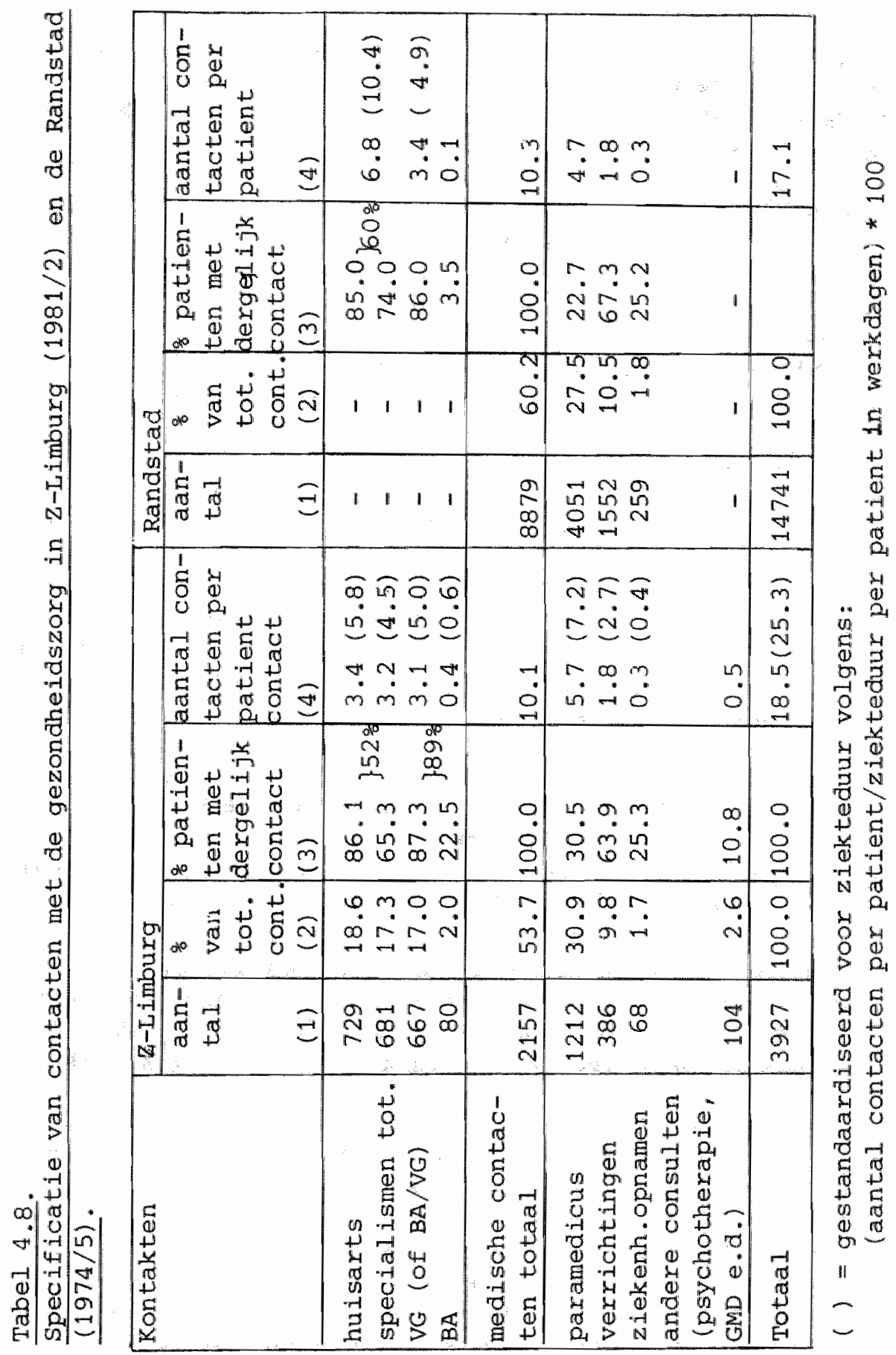


sultaten: Groothoff, 1981). De constatering van van oss (1980). dat arbeldsongeschikten gemiddeld beduidend meer gebrulk maken van medische voorzieningen dan andere Nederlanders, geldt klaarblijkelijk ook voor degenen aie nog niet arbeldsongeschikt, maar wel langdurlger ziek zijn (vgl. voor eensluidende resultaten ontrent de medische consumptie van WAO-ers ook Philipsen \& Halfens; 1983).

De contacten met de VG en $B A$ samen zijn ongeveer even frequent als met de HA, te weten, gemiddeld ongeveer een keer per mana. Dit suggereert, dat VG-en en BA-en hun activiteiten tenminste gedeeltelijk afstemmen op hetgeen de HA doet. Ex zljn nlettemin auteurs (van zal, 1981), die deze begelelaingefrequentie van vooral VG-en te laag vinden.

Een tweede conclusie, die naar anleiding van tabel 4.8 te trekken valt, heeft betrekking op de opvallende overeenkomsten in medische consumptie tussen de z-Limburgse en de Randstad-steekproef van Tordoir e.a. (1978). Vrijwel alle soorten contacten komen bij nagenoeg dezelfde percentages respondenten en in nagenoeg dezelfde frequenties voor. Bij wijze van voorbeeld: in beide onderzoeken is precies een kwart van de onderzoekspersonen tijdens de ziekteperiode in een ziekenhuls opgenomen geweest.

Niettemin is er een klein verschil:

- het gemiddeld aantal contacten met een paramedicus (doorgaans de fystotherapeut) is in de $z$-Limburgse steekproef niet alleen gestandaardiseerd, maar zelfs ook ongestandaardiseerd hoger, bovendien heeft dit antal betrekking op beduldend meer onderzoekspersonen; hier is ongetwijfeld het effect van de oververtegenwoordigde diagnosen van de bewegingsorganen merkbaar. Aan de andere kant kan men hierin wellicht ook een absolute toename van het gebruik van deze voorziening sedert 1974/75 zien.

Dit suggereert dat de interactie tussen patiênt en curatieve gezondheidszorg in de $z$-Limburgse steekproef gemiadela iets intenslever is dan in het Randstad-onderzoek.

Deze conclusle slutt goed aan bij hetgeen in de vorige paragraaf over het begin van de ziekteperiode naar voren is gekomen. Mar bovendlen blijkt deze conclusie ook opgeld te doen, wanneer men het tijasverloop tussen het laatste contact en het einde van de ziekteperiode bekijkt. Geniddeld 
verlopen er 3 werkdagen tussen het laatste medische consult en het einde van de ziekteperiode. Net zoals in het Randstad-onderzoek, is dit tijdsverloop voor degenen, die weer gaan werken, korter dan bij degenen, die het arbeidsproces verlaten (resp. 3.2 versus 7.3 werkdagen, $F=5.8, p=0.003$ ). Maar voor beide categorieën is dit tijdsverloop kort in vergelijking met het Randstad-onderzoek (resp. 3.9 en 20.5 werkdagen). Met name het verschil bif de niet-hervatters is aanmerkelijk.

Kijken wij tot slot van deze paragraaf naar de intensiteit en snelheid van handelen der sociaal-geneeskundigen. Voorzover de VG activiteiten ontplooit, gebeurt dat in de z-Limburgse steekproef gemiddeld genomen voor de eerste keer 22.4 werkdagen na datum ziekmelding. Dit is 0.6 werkdag eerder dan in het Randstad-onderzoek. Daar staat tegenover, dat de VG in het Randstad-onderzoek na verloop van 3 weken al de helft van alle respondenten heeft "gezien". De z-Limburgse VG heeft dan pas met 448 van de respondenten contact gehad. In een beperkt aantal gevallen is de Randstad-VG echter zeer laat met zijn activiteiten geweest.

Voor wat het aantal contacten van de VG betreft, het volgende. In de z-Limburgse- en Randstad-steekproef is deze contactfrequentie vrijwel gelijk (zie tabel 4.8). Omalat de Randstad-steekproef evenwel alleen betrekking heeft op GAKverzekerden, is het terwille van een zuivere vergelijking noodzakelijk dit gegeven ook te presenteren voor de GAK-verzekerden uit de $\mathrm{z}$-Limburgse steekproef. Welnu het blijkt dan dat de GAK-VG in de z-Limburgse steekproef gemiddeld 3.6 keer per 100 werkdagen contact opneemt met een zleke verzekerde, terwijl dat in de rest van de steekproef (zelf-administrerende Bedrijfsverenigingen, ambtenaren in de $z$ in van de Pensioenwet) gemiddeld 7.7 keer per 100 werkdagen gebeurt $(F=59.9 ; p=0.00)$. Hieraan dient evenwel toegevoegd te worden, dat bij het GAK de zgn. zlektewet-lekenrapporteur een gedeelte van het werk van de VG overneemt. Deze arbeidsverdeling tussen VG en lekencontroleur werd overigens bij het GAK pas in de loop van de zeventiger jaren ingevoerd. Dit is dan ook zeer waarschijnlijk de reden, waarom de contactfrequentie van de Z-Limburgse GAK-VG uit 1980/81 (3.6) een stuk beneden het nivo van die van de Randstad-GAK-VG uit de jaren 1974/75 ligt (4.9); in de Randstad heeft deze contactfrequentie mogelijkerwijze intussen een vergelijkbare 
daling laten zien.

Tot slot, de BA; ofschoon de $Z$-timburgse BA gemidaeld genomen actiever is, is $h i j / z i j$ niet erg snel. Pas na gemiddeld 41 dagen na datum ziekmelaing heeft hij/zij contact met de betreffende patiënten gehad (Randstad: 29 dagen; $\mathrm{n} \cdot \mathrm{b}$. belde berekeningen hebben alleen betrekking op werknemers, voor wie bedrijfsgezondheidszorg beschikbaar is).

4.4. Inhoudelijke aspecten van de contacten met de gezondheldszorg

In deze paragraaf stellen wij enkele kwalitatieve aspecten van de patiënt-gezonaheidszorg-interactie aan de orde. Hierbij gaat het om:

1. hetgeen tijdens de contacten over al-dan-niet-werken gezega is,

2. de wijze, waarop de contacten tot stand komen, en

3. het oordeel van de patienten over enkele aspecten van die contacten.

1. In de eerste plaats datgene, dat tijdens de contacten gezegd is over de verzuimcontinuering van de patiënten. Bij 71 van de z-Limburgse patiënten is de continuering van het verzuin tenminste een keer tijdens het behandelingsproces ter sprake geweest. Dit percentage is laag in vergelijking met het Randstad-onderzoek: daar heeft slechts 58 van de patiënten geen uitlating van enigerlei arts hieromtrent gehoord (zie tabel 4.9 in de bijlage). De verschillen in dit opzicht zijn bij de curatleve artsen, maar meer nog bij de verzekeringsgeneeskundigen te situeren. De curatieve artsen bespreken het onderwerp "verzuimcontinuering" bij resp. $59 \%$ (z-Limburg) en 628 (Randstad) van hun patiënten. De z-Limburgse VG-en sturen eveneens bij minder patiënten rechtstreeks met hun aanwijzingen. Bij 458 van de patiënten brengen $z i j$ de continuering van het verzuim expliciet ter sprake, terwijl dat in het Randstad-onderzoek bij 548 van de betrokkenen gebeurd is $(\times 2=6.0$; $d g f=1 ; p=0.05)$. Wanneer men alleen uitgaat van het aantal respondenten, dat ooit contact met een VG heeft. 
gehad, bedragen de percentages respectlevelijk 51 en 63.

De indruk van minder vaak direct sturende $z$-Limburgse VG-en wordt versterkt, wanneer men beziet, op wiens advies de werkhervatting tot stand komt. In de $\mathrm{z}-\mathrm{Lim}-$ burgse steekproef gebeurt dat in ruim 548 van de gevallen op aanwijzing van de $V G$; in het Randstad-onderzoek gebeurt dit op die manier in 608 van de gevallen. In de $\mathrm{Z}$-Limburgse steekproef is dan ook significant vaker sprake van een werkhervatting op eigen initiatief: namelijk bij respectievelijk $39 \%$ versus 228 van de patiënten in de Randstad. Dok hieruit blijkt, dat de zLimburgse respondenten door hun VG-en minder strak begeleid worden ( $z$ ie tabel 4.10 in de bijlage).

2. Overigens blijkt er binnen de z-Limburgse steekproef tussen GAK-VG-en en VG-en van andere uitvoeringsinstanties niet alleen een fors verschil te bestaan ten aanzien van het aantal VG-contacten, maar ook ten aanzien van de wijze, waarop deze contacten tot stand komen. Bleek in de vorige paragraaf, dat GAK-VG-en hun verzekerden belangrijk minder vaak "zien" dan andere VG-en (resp. 3.6 keer versus 7.7 keer per 100 werkdagen), nu kan hier nog het volgende aan toegevoegd worden. GAKVG-en blijken $71 \%$ van hun vervolgcontacten $(180 / 254)$ via een oproep te realiseren. Bij de andere VG-en wordt daarentegen $68 \%(163 / 238)$ van de vervolgcontacten via een directe terugbestelling geregeld; dat wil zeggen, wordt de datum van het vervolgcontact afgesproken tijdens het voorafgaande contact zelf (zie tabel 4.11 in de bijlage). De indruk bestaat, dat het vaker door de GAK-VG-en gehanteerde "oproep-volgt"-systeem meer door administratieve standaardprocedures wordt bepaald, dan door specifieke begeleidingsstrategieën, toegespitst op de individuele patienten zelf. Overigens is op deze plaats niet vast te stellen, welke effecten deze werkwijze van de GAK-VG-en op de ziekteduren heeft.

3. In dit onderzoek willen wij de aandacht niet enkel en alleen laten uitgaan naar die -formele- kanten van het behandelingsproces, die van invloed kunnen zijn op de uiteindelijke ziekteduur en wexkhervatting. Wij willen namelijk ook plaats inruimen voor de visie van de pa- 
tiëriten op hun gang door de gezondheidszorg. Uitgangspunt hierbij is de gedachte, dat patiënten met bepaalde verwachtingen naar de dokter gaan (Stimsom Webb, 1975). Op grond hilervan komt men na afloop tot een beoordeling van het betreffende contact met de gezondheidszorg. Deze evaluaties hebben wij in dit onderzoek wllen inventariseren. Hiexbij hebben wij drie verschillende aspecten onderscheiden:

- de duidelijkheid van het contact; de gebrekkige overdracht van de beschikbare informatie door de arts aan de patiënt is immers wel de Achilleshiel van het medisch functionexen genoend (Zola, 1981);

- het belang van het contact voor het herstel;

- het tijasverloop tot het eerstvolgende contact; op de belangrijke betekenis van de tijdsfactor in de beleving van een ziekteperlode is 0.2 . gewezen door Davis (1963).

Ten aanzien van deze drie aspecten hebben wij het oordeel van de patiënten over hun contacten met de gezondheidszorg geregistreerd. Welke resultaten dit heeft opgeleverd, staat weergegeven in tabel 4.12 in de bijlage.

Tabel 4.12 laat in de eerste plaats zien, dat het oordeel van de patiënten voor alledrie de onderscheiden aspecten signiflcante verschillen opleveren tussen de diverse soorten behandelaars. Meer toegespitst zijn de volgende conclusies te trekken:

* duldelijkheldsscore: het werk van de sociaal-geneeskundigen (VG en $B A$ ) wordt het meest onduidelijk gevonden. Mogelijk weerklinkt in dit oordeel niet alleen onbegrip over het inhoudelijk functioneren van deze artsen, maar ook onbegrip over de zin van hun activiteiten. Opvallend genoeg blijken ook opname in en ontslag uit het ziekenhuis een meer dan gemiddelde onduidelijkheid bij de patiënten te weeg te brengen. De overige soorten contacten ontlopen elkaax bij deze beoordeling nauwelijks.

* belangrijkheldsscore: de consulter bij de medische specialisten, opname en ontslag uit het ziekenhuis alsmede de verrichtingen worden door de patiënten als het belangrijkst voor hun herstel ervaren. De activiteiten van de VG-en en BA-en worden door de patiënten als nagenoeg 
volledig onbelangrijk voor het herstel van hun ziekte gekwalificeerd

* tijdsverloopscore: in dit opzicht zijn de verschillen te verwaarlozen: dit is wellicht (mede) te wijten aan een niet volledig gelukte meting van dit patiëntenoordeel.

Tot zover de visie van de patiënten.

\subsection{De wachttijden}

In deze paragraaf willen wij doordringen tot de kern van dit hoofdstuk, te weten de identificatie van de ziekteduurverlengende factoren afkomstig uit de patiënt-gezondheidszorginteractie. In overeensteming met het werk van Tordoir c.s. (1978) hebben wij 8 verschillende categorieën van wachttijden onderscheiden. Dit zijn:

- de wachttija tussen datum ziekmelding en eerste consult,

- de periode( $n)$ tijdens de verwijzing van huisarts naar specialist;

- de periode( $n)$ tijdens de verwijzing van arts naar paramedicus;

- de periode( $n)$ tijdens de verwijzing van specialist naar specialist;

- de periode( $n$ ) tussen opdracht tot en uitvoering van een verrichting;

- de periode( $n$ ) tussen een diagnostische verrichting en het eerstvolgende contact met de opdrachtgevende axts;

- de wachttijd voor ziekenhuisopname, en

- de stuurloze periode( $n$ ).

In deze laatstgenoemde periode is geen koers voor de behandeling uitgezet; deze periode ontstaat, wanneer een arts zijn behandeling beëindigt of onderbreekt, zonder aan de patiënt duidelijk te maken, hoe het nu verder met hem of haar moet.

De essentie van deze wachttijden is, dat in die perioden geen voortgang in het (para-)medisch behandelingsproces wordt geboekt. Dit is -globaal genomen- het geval, wanneer er sprake is van een verwijzing dan wel van een nog niet begonnen of gestaakte behandeling. De onderliggende aanname hierbij is dan, dat als gevolg van deze wachttijden ook het herstel en werkhervatting later optreden. De ook zonder me- 
dische bemoeienis verlopende natuurlijke genezingsprocessen blijven hiex buiten beschouwing.

Voor alle volledigheld: de periode, die verloopt tussen het laatste contact met de gezondheidszorg en de werkhervatting, wordt niet gexekend tot enigerlei vorm van wachttijden. Dit is beslist in navolging van Tordoir c.s. (1978).

Belangrijk is verder nog te vermelden, dat het hier uitsiuitend om extra-murale behandelingsperioden gaat. Wat er binnen het ziekenhuis gebeurt, valt buiten het bestek van deze studie. Overigens lijkt het fenomeen van wachttijden tijdens opname ook te bestaan. Cremers vond in 1974, dat mar 1iefst ruim 248 van de opnametijd een geringe medische en/of verpleegkundige relevantie had; deze "facultatieve" dagen concentreerden $z i c h$ vooral aan het einde van de opnameperiode (zie ook hoofdstuk 2).

Tot zover -beknopt- een beschrijving van de acht typen van wachttijden. Tabel 4.13 geeft weer, hoe groot de respectievelijke wachttijden zijn in de z-Limburgse en de Randstadsteekproef. De eerste conclusie, die deze tabel oplevert, betreft de totale gemiddelde netto-omvang van de wachttijden in verhouding tot de totale ziekteduur. Bij deze berekening zijn dubbeltellingen vermeden en is bij eventuele verschillende gelijktijdige behandelingsprocessen uitgegaan van de belangrijkste behandelings" 1 jon".

Hierbij zijn de percentages niet voor de volledige $z-L i m-$ burgse steekproef berekend. zoals bekend, heeft het Randstad onderzoek alleen betrekking op GAK-verzekerden. Voor een belangrijk gegeven als het percentage wachttijd is een zo zuiver mogelijke vergelijking gewenst. Vandaar dat de Randstadcijfers in tabel 4.13 alleen vergeleken worden met de gegevens voor de GAK-verzekerden uit de $z$-Iimburgse steekproef. 
Tabe1 4.13.

Specificatie van de wachttijien tijdens de behandeling van GAK-verzekerden in Z-Limburg (1981/82) en Noord/zuld-Holland $(1974 / 75)$

\begin{tabular}{|c|c|c|c|c|c|c|}
\hline & \multicolumn{3}{|c|}{ Zuid-Limburg (GAK) } & \multicolumn{3}{|c|}{$\bar{N} / \bar{Z}-$ Holland (GAK) } \\
\hline & \begin{tabular}{|l|} 
abs. \\
aantal \\
werk- \\
dagen \\
$(1)$
\end{tabular} & $\begin{array}{l}\text { vih. } \\
\text { totale } \\
\text { ver- } \\
\text { zuim } \\
(2)^{*}\end{array}$ & $\begin{array}{l}\text { v.d. } \\
\text { totale } \\
\text { wacht- } \\
\text { tijd } \\
(3)\end{array}$ & $\begin{array}{l}\text { abs. } \\
\text { aanta1 } \\
\text { werk- } \\
\text { dagen } \\
(4)\end{array}$ & $\begin{array}{l}8 \text { v.h. } \\
\text { totale } \\
\text { ver- } \\
\text { zuim } \\
(5) *\end{array}$ & $\begin{array}{l}\text { v.d. } \\
\text { totale } \\
\text { wacht- } \\
\text { tijd } \\
(6)\end{array}$ \\
\hline $\begin{array}{l}\text { - totale verzuim- } \\
\text { tijd in werka. }\end{array}$ & 11296 & 100.0 & - & 70110 & 100.0 & - \\
\hline $\begin{array}{l}\text { netto totale } \\
\text { wachttijd in } \\
\text { werkdagen }\end{array}$ & 2194 & 19.4 & 100.0 & 13695 & 19.5 & 100.0 \\
\hline $\begin{array}{l}\text { 1. wachttijd voor } \\
\text { le consult }\end{array}$ & 88 & $0.8(7)$ & 4.0 & 1403 & $2.0(7)$ & 10.2 \\
\hline $\begin{array}{l}\text { arts naar spec. } \\
\text { 3.verwijz. arts }\end{array}$ & 354 & $3.1(3)$ & 16.1 & 2530 & $3.6(1)$ & 18.5 \\
\hline $\begin{array}{l}\text { naar paramedic. } \\
\text { 4. verwijz. spec. }\end{array}$ & 144 & $1 \cdot 3(5)$ & 6.6 & 1723 & $2.5(4)$ & 12.6 \\
\hline $\begin{array}{l}\text { naar specialist } \\
\text { 5.periode tussen }\end{array}$ & 54 & $0.5(8)$ & 2.5 & 499 & $0.7(8)$ & 3.6 \\
\hline $\begin{array}{l}\text { opdracht en uit- } \\
\text { voer.verrichting }\end{array}$ & 123 & $1.1(6)$ & 5.6 & 2399 & $3.4(3)$ & 17.5 \\
\hline $\begin{array}{l}\text { 6. periode tussen } \\
\text { diagnost. ver- } \\
\text { richting en } \\
\text { eerstvolg. con- } \\
\text { sult met opdr. } \\
\text { gevende arts }\end{array}$ & 403 & $3.6(2)$ & 18.4 & 2490 & $3.6(1)$ & 18.2 \\
\hline 7. wachttijd opna- & & & & & & \\
\hline melijst ziekenh & 336 & $3.0(4)$ & $15 \cdot 3$ & 1522 & $2 \cdot 2(5)$ & 11.1 \\
\hline 8.stuurl.periode & 692 & $6.1(1)$ & 31.5 & 1439 & $2.1(6)$ & 10.5 \\
\hline
\end{tabular}

* tussen haakjes is de rangorde der wachttijdsoorten naar omvang aangegeven.

* omdat dit het totale percentage netto-wachttijd betreft, is het iets lager dan de som van de onderscheiden categorleën wachttijden. In de $z$-Limburgse gegevens zijn daarentegen aubeltellingen altijd vermeden. 
Vijf van de acht onderscheiden typen wachttijden blijken in de $z$-Limburgse steekproef minder onvangrijk te zijn dan in het Randstad-bestand. Dit zijn: de wachttijd voor het le medische consult, de verwijzing van de huisarts naar een speclalist, de verwijzing van een arts naar een paramedicus, de verwijzing van een specialist naar een andere specialist en de periode tussen de opdracht en de uitvoering van een verrichting. Al deze perioden beslaan in de z-Iimburgse steekproef rinder tijd dan in het Randstad onderzoek.

De periode tussen een diagnostische verrichting en het eerstvolgende consult met de opdrachtgevende arts duurt in het $\mathrm{z}$-Limburgse en het Randstad-bestand precies even lang. Alleen de wachttijden voor opname in het ziekenhuis en de zogenaamde stuurloze periode zijn in de z-Limburgse steekproef omvangrijker. Per saldo is het totale wachttijdenpercentage in de $\mathrm{z}$-Limburgse steekproef nagenoeg even hoog als dat in de Randstad-steekproef: 19.48 versus 19.58 .

wanneer men kijkt naar de rangorde, die de diverse typen van wachttijden qua omvang vormen, zijn duidelijk regelmatigheden in de beide onderzoeken te onderkennen. In beide onderzoeken neemt de wachttljd na de diagnostische verrichting een kwantitatief belangrijke plaats in. In beide onderzoeken ook blijken de wachttijd voor het eerste medische consult en de verwijzing van specialist naar specialist relatief weinig tijd in beslag te nemen.

Daarentegen is in de Randstadsteekproef de verwijzingsperiode van huisarts naax specialist het langst, terwijl in de $z$ Limburgse steekproef de stuurloze periode verreweg de meeste tijd beslaat. Onder de GAK-verzekexden van het $z$-Limburgse onderzoek komen de stuurloze dagen bijna drie keer zoveel voor als in het Randstad-bestand. Bovendien is in de $z-I$ imburgse steekproef de wachttijd voor ziekenhuisopname iets langer en wel bijna even lang als de totale opnameduur, te weten resp. 3.08 en $3.3 \%$ van de totale verzuimduur voor de gehele steekproef; dezelfde gegevens bedragen voor de Randstad-steekproef 2.28 wachttijd voor ziekenhulisopname en $4.9 \%$ duur van de opname zelf (over dezelfde problematiek: Ph1lipsen, 1973).

wanneer men erop uit is, om de vergelijking tussen het $z-$ Limburgse en het Randstad-onderzoek zo exact mogelijk te laten zijn, zal men moeten corrigeren voor verschillen in leeftijdsopbouw tussen de beide steekproeven. Zoals bekend, 
zijn in het z-Limburgse bestand de 55-plussers ondervertegenwoordigd. Wanneer men zich nu realiseert (zie tabel 4.14 in de bijlage), dat juist deze 55-plussers beduidend meer wachtdagen dan gemiddeld meemaken, wordt de noodzaak van een standaardisatie op leeftijd overduidelijk.

In tabel 4.15 in de bijlage is deze berekening uitgevoerd, met als resultaat, dat het voor leeftijdverschillen gecorrigeerde netto-wachttijd-percentage voor de $z$-Limburgse GAKverzekerden 22.18 bedraagt. Dit is ruim 2.58 hogex dan het corresponderende gegeven uit de Randstad uit 1974/75. Gelet op de gegevens van tabel 4.14 in de bijlage zijn deze extra $2.6 \%$ cok in hoofdzaak weer te situeren in de stuurloze periode.

Tot zover de beschrijving van de wachttijden voor de gehele $\mathrm{z}$-Iimburgse steekproef bestaande uit GAK-verzekerden. Zoals bekend, bevat dit onderzoek niet alleen gegevens over GAKverzekerden, maar zijn in deze steekproef ook ambtenaren en personeelsleden van bij zelf-administrerende Bedrijfsverenigingen aangesloten werkorganisaties vertegenwoordigd. Om na te gaan, of de verzekeringswijze tot verschillen in wachttijden leidt, hebben wij in tabel 4.16 de gegevens van de totale z-Limburgse steekproef in drie groepen respondenten opgesplitst. In de eerste groep zijn alle respondenten opgenomen, die werkzaam zijn bij omslagleden van het GAK dan wel bij zgn. AKERS; dit zijn ondernemingen, die niet verzekerd zijn bij het GAK, maar er wel de ziektewetcontrole door laten uitvoeren. Deze groep kamt overeen met de respondenten van het Randstad onderzoek.* In de andere twee groepen $z i j n$ respectievelijk de ambtenaren in de $z$ in van de Pensioenwet opgenomen en de personeelsleden van werkorganisaties, die aangesloten zijn bij zelfadministrerende Bedrijfsverenigingen.

Deze opsplitsing van wachttijden (tabel 4.16) levert als resultaat, dat de beide andere groepen van respondenten duidelijk minder lange wachttijden tijdens hun ziekteperiode meemaken dan de GAK-verzekerden. Dit geldt vooral voor de werknemers van bedrijven en instellingen, die bij een

deze groep respondenten is gemiddeld lets jonger dan de overige patiënten. 


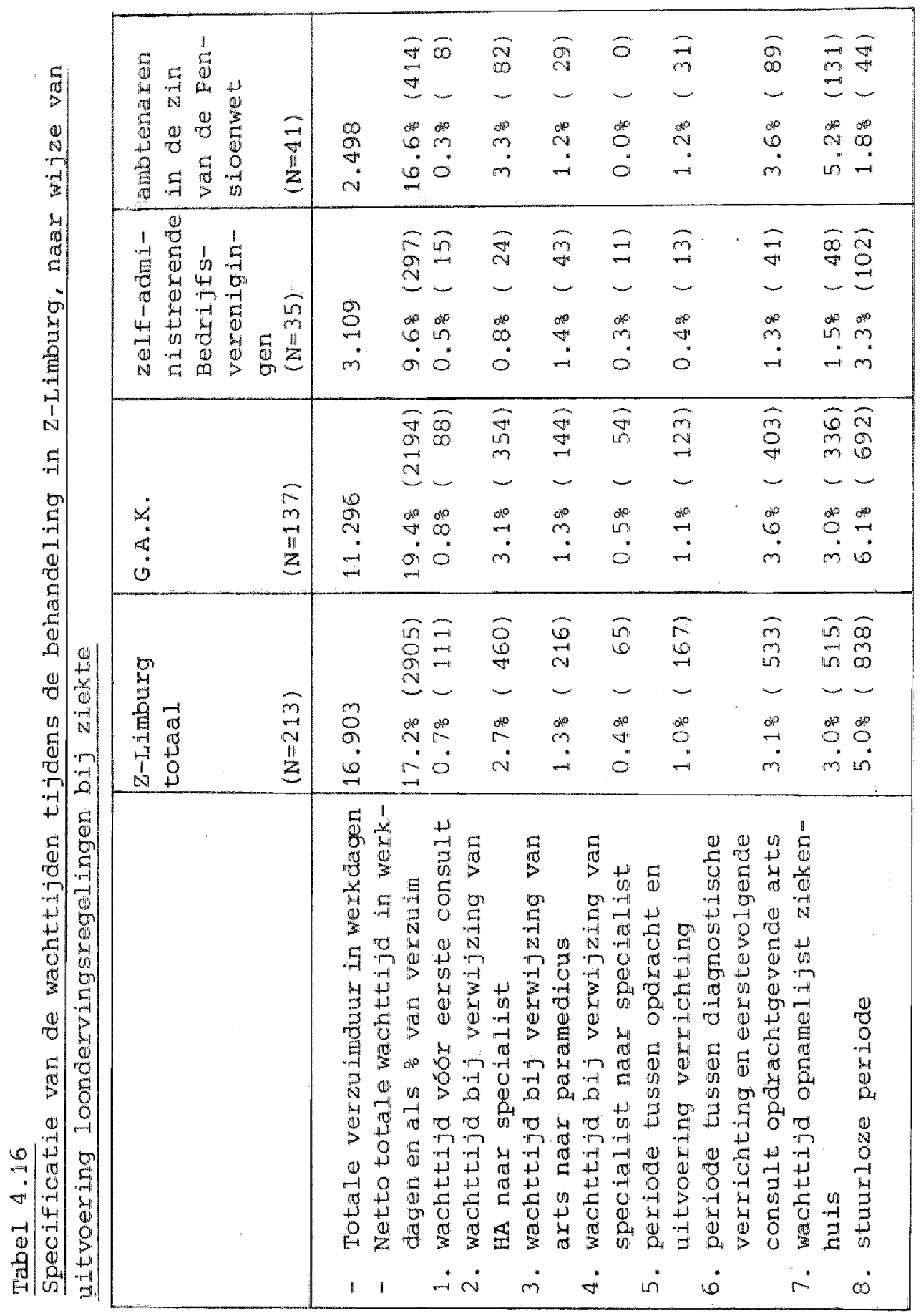


zelf-administrerende Bedrijfsvereniging zijn aangesloten. Vooral ook ten aanzien van de stuurloze periode blijken de GAK-verzekerden ten opzichte van de beide andere groepen af te steken.

Hiermee sluiten wij de specifieke beschrijving van de hoogte van het wachttijapercentage in $\mathrm{z}$-Limburg, in vergelijking tot dat uit de Randstad, af. In de rest van deze paragraaf besteden wij nog aandacht aan enkele bijzondere kenmerken van de wachttijden, waarbij opnieuw de gehele z-Limburgse steekproef in de analyse wordt betrokken.

Niet onverwacht blijken gemiddelde wachttijd en ziekteduur met elkaar te correleren: $r=0.46, p=0.001$. De hoogte van deze correlatie is echter niet van dien aard, dat wachttijd en ziekteduur volledig in pas lopen. Dat wil zeggen, dat een lange gemiddelde verzuimauur niet perse hoeft samen te gaan met een lange gemiddelde wachttijd, en omgekeerd. Om deze reden blijft het belangrijk de voor ziekteduur gecorrigeerde wachttijd, oftewel het wachttijdpercentage, te berekenen. Dit is gebeurd in tabel 4.17, waar de gegevens per diagnosecategorie gespecificeerd zijn en opnieuw een vergelijking met het Randstad-onderzoek wordt gemaakt. 
Tabe1 4.17.

Gemiddelde wachttijd, ziekteduur en percentage wachttijd naax dilagnosecategorie in z-Limburg en de Randstad.

\begin{tabular}{|c|c|c|c|c|c|c|c|c|}
\hline \multirow[b]{2}{*}{ Diagnosen } & \multicolumn{4}{|c|}{$\mathrm{z}$-Limburg volledig } & \multicolumn{4}{|c|}{ Randstad } \\
\hline & $\begin{array}{l}\text { gemia. } \\
\text { wacht- } \\
\text { tijd } \\
\text { in } \\
\text { werk- } \\
\text { dagen }\end{array}$ & $\begin{array}{l}\text { gemid. } \\
\text { ziek- } \\
\text { te- } \\
\text { duur } \\
\text { in } \\
\text { werk- } \\
\text { dagen }\end{array}$ & wacht & $t^{\mathrm{N}}=$ & $\begin{array}{l}\text { gemid. } \\
\text { wacht- } \\
\text { tijd } \\
\text { in } \\
\text { werk- } \\
\text { dagen }\end{array}$ & $\begin{array}{l}\text { gemid. } \\
\text { ziek- } \\
\text { te- } \\
\text { duur } \\
\text { in } \\
\text { werk- } \\
\text { dagen }\end{array}$ & wacht. & \\
\hline $\begin{array}{l}\text { - Infectie- } \\
\text { ziekten } \\
\text {-nieuwvor- }\end{array}$ & 4,5 & $37 \cdot 5$ & 128 & 2 & 8.3 & 49.1 & 178 & 13 \\
\hline mingen & 9.5 & 188.5 & 58 & 4 & 10.4 & 107.2 & 108 & 9 \\
\hline $\begin{array}{l}\text {-allergien } \\
\text {-psychische }\end{array}$ & 23.7 & 134.3 & 188 & 4 & 45.4 & 157.9 & 298 & 12 \\
\hline $\begin{array}{l}\text { ziekten } \\
\text {-zenuwstelsel }\end{array}$ & 18.1 & 73.3 & 258 & 32 & 12.6 & 82.2 & 158 & 130 \\
\hline $\begin{array}{l}\text { en zintuigen } \\
\text {-circulatie- }\end{array}$ & 17.5 & 103.1 & 178 & 11 & 17.4 & 74.7 & 238 & 44 \\
\hline $\begin{array}{l}\text { apparaat } \\
\text { - ademhalings- }\end{array}$ & 10.8 & 136.5 & 108 & 14 & 22.7 & 123.6 & $18 \%$ & 87 \\
\hline $\begin{array}{l}\text { wegen } \\
\text {-spijsverte- }\end{array}$ & 11.9 & 89.6 & 138 & 12 & 10.6 & 66.5 & 168 & 44 \\
\hline $\begin{array}{l}\text { ringsorganen } \\
\text {-urogenitaal }\end{array}$ & 11.8 & 65.8 & 188 & 20 & 16.8 & 70.4 & 248 & 108 \\
\hline stelsel & 10.4 & 73.9 & 148 & 8 & 13.1 & 69.7 & 198 & 32 \\
\hline $\begin{array}{l}\text {-huidziekten } \\
\text {-bewegings- }\end{array}$ & 11.2 & 60.4 & 198 & 5 & 3.4 & 40.3 & 88 & 9 \\
\hline apparaat & 15.5 & 72.1 & 218 & 67 & 22.4 & 89.9 & $25 \%$ & 217 \\
\hline -misvormingen & 6.0 & 119.5 & 58 & 2 & 23.0 & 141.5 & 168 & 2 \\
\hline -ongevallen & 7.0 & 54.4 & 138 & 33 & 5.1 & 56.2 & 98 & 135 \\
\hline Totaal & 13.4 & 79.0 & 178 & 213 & 15.9 & 81.3 & 208 & 842 \\
\hline
\end{tabular}

Tabel 4.17 laat zien, dat in vrijwel alle diagnosecategorieen het wachttijdpercentage in de $z$-Limburgse steekproef lager ligt dan in het Randstad-bestand. Dit geldt evenwel niet voor de patiënten met een psychische ziekte (25\% versus 15\%) en voor degenen, die een ongeval hebben gehad. Daarnaast 
blijkt, dat in de $z$-Iimburgse steekproef -net zoals in het Randstad onderzoek- de frequent voorkomende patiënten met een aandoening aan het bewegingsapparaat meer dan gemiddeld lange wachttijden meemaken. Bij deze diagnosecategorie gaat het vooral om de vakgebieden orthopedie en rheumathologie.

Dat deze vakgebieden inderdaad de knelpunten vormen, blijkt uit de tabellen 4.18 en 4.19 in de bijlage. Daarin is per specialisme gespecificeerd, hoe groot de wachttijden zijn tijdens de verwijzing van HA naar specialist en van specialist naar een andere specialist, alsmede de wachttijd voor zlekenhuisopname. In al deze opzichten blijken de orthopedie en rheumathologie verreweg de langste wachttijden te veroorzaken, op afstand gevolgd door de neurologie, de cardiologie en de interne geneeskunde. Bij de chirurgie bestaat een redelijk lange wachttijd voor ziekenhuisopname.

Uit tabel 4.20 blijkt tenslotte, dat de stuurloze periode vooral voorkomt bij de psychische aandoeningen: niet minder dan $17,6 \%$ van alle ziektedagen van de patiënten met dergelijke ziekten verloopt, zonder dat enig behandelingsplan wordt uitgezet of uitgevoerd.

Aan het einde van deze paragraaf nog aandacht voor de wachttijden bij respectievelijk de werkhervatters en de niet-hervatters. Tabel 4.21 in de bijlage laat zien, dat zowel in de z-Limburgse steekproef als in het Randstad-onderzoek de gemiddelde absolute wachttijd bij de niet-hervatters beduidend langer is dan bij de hervatters. Ofschoon de niet-hervatters in beide onderzoeken slechts $13 \%$ van alle respondenten uitmaken, zijn zij wel verantwoordelijk voor maar liefst 298 ( $z$-Limburg) en $30 \%$ (Randstad) van alle wachttijden. Vanzelfsprekend moet men ook bij deze vergelijking rekening houden met de gemiddelde verzuimduur; in dit geval betekent dit dan, dat het wachttijdenpercentage -in tegensteling tot het gegeven van daarnet- voor de niet-hervatters lager uitvalt dan voox de hervatters (zie ook tabel 4.21).

Een vergelijking aan de hand van het wachttijdenpercentage is hier evenwel minder juist, aangezien eenmalige gebeurtenissen bij de niet-hervatters over een veel langere gemiddelde verzuimduur worden uitgemiddeld; hierdoor moet bij hen welhaast een lager wachttijdenpercentage optreden. Beter is het daarom, de gemiddelde wachttijd voor hervatters en niethervatters per gebeurtenis te vergelijken; dit gebeurt in tabel 4.22 in de bijlage. Daaruit blijkt, dat de conclusie 
van Tordoir c.s. in dit verband onverminderd gehandhaafd kan blijven, bij de niet-hervatters lijkt het gezondheidszorgsysteem trager te reageren dan bij de hervatters. Immers, alle typen van wachttijden -op één na- kamen bij de niethervatters in omvangrijkere mate voor. Extreem is het verschil bij de zogenaamde stuurloze perioden. Wanneer de niethervatters stuurloos zijn, zijn zij dat ruim 5 keer zo lang als de hervatters. Dit $\mathrm{z}$-Limburgse beeld stemt nagenoeg vollealg overeen met de gegevens uit het Randstad-onderzoek. Alleen blijken in dat onderzoek de verwijzingsperiode van huisarts naar specialist en de periode op de opnamelijst relatief grotere verschillen tussen hervatters en niet-hervatters op te leveren dan in de $\mathrm{z}$-Limburgse steekproef. Na de constatering, dat volgens de gegevens van beide ondexzoeken het gezondheidszorgsysteem bij niet-hervatters trager lijkt te reageren, rijst onmiddelijk de vraag naar de oorzaak van dat verschijnsel. Verdwijnen de niet-hervatters ult het arbeidsproces, omdat zij zulke lange wachttijden meemaken? of treedt ait verschijnsel op als gevolg van het felt, dat de behandelaars bij voorbaat al weten of op grond van normatieve overwegingen van mening zijn, dat een maximaal efficiënte procedure tijdens de behandeling er niet meer toe doet? In het eerste geval zijn de wachttijiden de oorzaak van de latere arbeidsongeschiktheid, in het tweede geval zijn de wachttijden het gevolg van de voorspelde latere uittrede uit het arbeidsproces.

Het is niet gemakkelijk, een van deze twee mogelijkheden als waarschijnlijkste aan te wijzen. Wij laten dit probleem hiex dan ook verder rusten. Belangrijker is het nu, om de betekenis van enkele gegevens uit dit hoofdstuk in een breder verband te interpreteren. Dit gebeurt in de volgende paragraaf.

4.6. De wachttijden geconfronteerd met het aanbod van gezondheidszorgvoorzieningen.

zoals gezegd, willen wij in deze paragraaf komen tot een interpretatie van de voornaamste gegevens uit het voorgaande. zowel in het vooronderzoek als in dit onderzoek gingen wij ervan uit, dat het wachttijdenprobleem in z-Limburg omvangrijker zou zijn dan elders in Nederland en wel vanwege het geringere anbod van gezondheldszorgvoorzieningen in $z$-Lim- 
burg.

Om deze basisveronderstelling te toetsen, hebben wij de zLimburgse wachttijdien steeds vergeleken met de enig andere bekende inventarisatie van wachttijden, te weten, die van Tordoir c.s. (1978). Zoals in het begin van dit hoofdstuk al is vermeld, hebben deze gegevens betrekking op Noord- en zuid-Holland, in de jaxen 1974 en 1975. Deze gegevens zijn dus 7 jaar ouder dan de z-Limburgse data uit dit onderzoek. $\mathrm{Nu}$ heeft de ontwikkeling van het aanbod van gezondheidszorgvoorzieningen in die 7 jaar bepald niet stilgestaan. Integendeel, sommige voorzieningen, zoals het aanbod van 2e-1ijns-artsen, hebben in dit tijasbestek een grotere vlucht genomen; in z-Limburg is dit niet anders dan in de rest van Nederland. Andere voorzieningen, zoals het aantal ziekenhuisbedden, zijn juist ingekrompen. Uitgaande van de veronderstelling, dat er een relatie bestaat tussen het aanbod van gezondheidszorgvoorzieningen en de omvang vam de wachttijden, mag men daarom niet zonder voorbehoud de wachttijden uit de beide onderzoeken met elkaar vergelijken, zoals wij tot nu toe gedaan hebben. Men zal de ontwikkeling van het gezondheidszorgaanbod in die zeven jaar bij de interpretatie moeten betrekken. Om dit te kunnen doen, hebben wij tabel 4.23 gemaakt. 
Tabe1 4.23

Practiserende artsen en zlekenhuisbedden in Limburg, Noorden Zuid-Holland en geheel Nederland, per 10.000 inwoners $(1.1 .1975$ en 1.1 .1981$)$

\begin{tabular}{|c|c|c|c|c|c|c|c|}
\hline & & $\begin{array}{l}\text { huls- } \\
\text { arts- } \\
\text { en }\end{array}$ & $\begin{array}{l}\text { spe- } \\
\text { cia- } \\
\text { listen }\end{array}$ & $\begin{array}{l}\text { sociaal } \\
\text { genees- } \\
\text { kundigen }\end{array}$ & $\mid \begin{array}{l}\text { overi- } \\
\text { artsen } \\
\text { (in op- } \\
\text { leid.) }\end{array}$ & $\left\{\begin{array}{l}\text { totaal } \\
\text { artsen }\end{array}\right.$ & $\begin{array}{c}\text { zieken- } \\
\text { huis- } \\
\text { bedden }\end{array}$ \\
\hline \multicolumn{8}{|l|}{1.1 .1975} \\
\hline $\begin{array}{l}\text { Limburg } \\
\text { Noord- } /\end{array}$ & (1) & 3.4 & 3.8 & 0.7 & 2.7 & 10.6 & 55.5 \\
\hline z-Holland* & (2) & 3.6 & 5.7 & 0.9 & 6.8 & 17.0 & 57.6 \\
\hline Nederland & (3) & 3.5 & 4.9 & 0.8 & 5.6 & 14.9 & 54.5 \\
\hline \multicolumn{8}{|l|}{1.1 .1981} \\
\hline \multicolumn{8}{|l|}{$\begin{array}{l}\text { Herstruk- } \\
\text { turerings- } \\
\text { gebied }\end{array}$} \\
\hline $\begin{array}{l}\text { Limburg } \\
\text { Noord- } /\end{array}$ & (4) & 3.8 & 6.1 & 1.1 & 6.8 & 17.8 & $54.6 *$ * \\
\hline z-Holland & (5) & 3.9 & 7.5 & 1.0 & 9.2 & 21.6 & 56.8 \\
\hline Nederland & (6) & 3.9 & 6.6 & 0.9 & 7.6 & 19.0 & 51.8 \\
\hline
\end{tabular}

bron:

- de Hoofdinspecteur voor de Volksgezondheid

Uit deze tabel blijkt inderdaad, dat de tijd niet heeft stilgestaan. De ontwikkeling is zelfs van dien aard, dat het z-Limburgse gezondheidszorgaanbod in 1981 op belangrijke onderdelen lets beter ontwikkeld is dan dat van de Randstad in 1975. Er $z i j n$ in $z-L i m b u r g$ in 1981 lets meer huisartsen en specialisten gevestigd dan in de Randstad in 1975. Deze situatie heeft tot gevolg, dat het tot een toetsing van de basisveronderstelling -langere wachttijden als gevolg van een minder groot gezondheidszorgaanbod in z-Limburg- in dit onderzoek niet echt is kunnen komen.

in deze twee provincies zijn 4 academische ziekenhuizen gevestigd, hetgeen het grote aanbod van gezondheidszorgvoorzieningen aldaar mede verklaart.

** voor de gehele provincie Limburg. 
In feite hebben wij nu het onderzoek van Tordoir c.s. onder ongeveer dezelfde condities van gezondheidszorgvoorzieningen herhaald. De verschillen, die er desalniettemin tussen beide onderzoeken gebleken zijn, kunnen ons inziens aan de volgende verschijnselen toegeschreven worden:

- Het feit, dat vrijwel alle verwijzingsperioden in de $z$ Limburgse steekproef minder lange wachttijden opleveren is vermoedelijk het gevolg van een iets intensievere patiënt-gezondheidszorg-interactie. Het behandelingsproces start gemiddeld iets sneller, er is een kleiner tijdsverloop tussen het laatste medische consult en het einde van de ziekteperiode -dit geldt vooral voor de niet-hervatters-, en het aantal (para-)medische contacten is groter.

Aan deze verschillen ligt ten eerste een oververtegenwoordiging van de aandoeningen aan het bewegingsapparaat ten grondslag. Deze zorgt in ieder geval voor meer contacten met de fysiotherapeut, die -eenmaal begonnen met zijn behandeling- gedurende lange perioden het ontstaan van wachttijden onmogelijk maakt. Hierbij is het evenmin ondenkbaar, dat de sterke groei van het aantal fysiotherapeuten in het recente verleden zonder meer al tot een groter gebruik van deze voorziening heeft geleid. Ten tweede zouden wij op het volgende willen wijzen. Volgens Smulders, van Leeuwen en van Nooten (1983) is de ziektewetcontrole en de meer algemene sociale controle ten opzichte van ziekteverzuim in de afgelopen 2 à 3 jaar sterk toegenomen. Wanneer deze indruk juist is, kan men veronderstellen, dat de patiënten zich het liefst zo snel mogelijk onder medische begeleiding willen plaatsen, als legitimering van hun afwezigheid wegens ziekte.

- Desondanks is de stuurloze periode in de $z$-Limburgse steekproef een stuk omvangrijker dan in het Randstad onderzoek. Met name is dit het geval bij de GAK-verzekerden.

Dit verschil is mogelijk te wijten aan het fejt, dat $z_{-}$ Limburgse (GAK) -VG-en in het algemeen in verhouding tot het Randstad-onderzoek met hun eerste contacten iets later zijn en bovendien, dat ze iets minder direct zijn met hun uitspraken over verzuimcontinuering en werkhervatting.

Verder is het zo, dat de GAK-VG-en in de z-Limburgse 
steekproef in het algemeen duidelijk minder vaak contact opnemen met hun zieke verzekerden dan de GAK-VG-en in de Randstad-steekproef. Dit verschijnsel is mogelijk het gevolg van de grotere werklast van de GAK-VG-en in $z$ Limburg in vergelijking met hun collega's elders in $\mathrm{Ne}-$ derland (Soeters, 1980a en b).

Anderzljas moet men zich realiseren, dat de opvattingen van uitvoeringsinstanties en verzekeringsgeneeskundigen omtrent de wijze van controleren veranderd zijn ten opzichte van de tijd, toen het Randstad-onderzoek werd uitgevoerd (1974/75). Met name moet hierbij gewezen worden op het feit, dat sedert $1974 / 75$ de lekencontroleur bij het GAK een belangrijkere rol toebedeeld heeft gekregen, en een deel van het werk van de VG heeft overgenomen.

Verder is in dit onderzoek vastgesteld, dat de GAK-verzekerden ook langere stuurloze perioden meemaken dan andere verzekerden in $z$-Limburg, (ambtenaren in de zin van de Pensioenwet en werknemers van bij zelf-administrerende BV-en aangesloten werkorganisaties). Mogelijk in verband hiermee staat het feit, dat GAK-VG-en minder vaak contact opnemen met hun zieke verzekerden dan VG-en van andere uitvoeringsinstanties. Ook hieraan dient evenwel toegevoegd te worden, dat bij het GAK de functie van de zgn. $z W-l e k e n r a p p o r t e u r$ bestaat. Deze functionaris heeft ook contact met de verzekerden, maar de activiteiten van deze functionarissen zijn bij de bepaling van de wachttijden als zijnde niet-medisch buiten beschouwing gelaten.

Naast de geringexe contactfxequentie van de GAK-VG-en is verder ook nog vastgesteld, dat de GAK-VG-en vaker hun vervolgcontacten via een oproep regelen, terwijl de andere VG-en juist meer met rechtstreekse afspraken werken. De indruk bestaat, dat het "oproep-volgt-systeem" meer door administratieve standaardprocedures wordt bepaald dan door specifleke begeleidingsstrategieën, toegespitst op de individuele patiënten zelf. Dit "oproepvolgt-systeem" geeft de verzekerde enerzijds de indruk onder verzekeringsgeneeskundige begeleiding te staan, maar werkt andexzijds het ontstaan van stuurloze perioden in de hand.

Aan deze gegevens dient evenwel nog een algemene opmer- 
king toegevoegd te worden. Het is onjuist, om de verantwoordelijkheid voor het ontstaan van stuurloze perioden uitsluitend bij VG-en te willen leggen. In dit onderzoek is gebleken, dat stuurloze perioden vooral ontstan bij patiënten met psychische aandoeningen. Dit wijst er wellicht op, dat de gezondheidszorg mar moeilijk raad weet met aandoeningen van een psychisch karakter. Hier ligt mogelijk een terrein voor kwaliteitsverbetering van de zorg in de eerste 1ijn, maar wellicht ook elders in de gezondheidszorg.

Tenslotte is het zo, dat het ontstaan van stuurlowe perioden tenminste gedeeltelijk ook toegeschreven moet worden aan de verantwoordelijkheid van de patienten zelf. Immers, een actieve patiënt zal zich na beëindiging van de behandeling in verbinding stellen met zijn $H A, B A$ of VG. De verschillen in stuurloze perioden tussen GAK-verzekerden en andere zieke werknemers kunmen daarom wellicht voor een deel ook toegeschreven worden aan populatieverschillen in het verzekerdenbestand. Mogelijk is het zo, dat de langere stuurloze perioden bij het GAK mede het gevolg zijn van een afwijkend patiënten- en klachtenaanbod. Dat de werking van patiënten-invloeden zelfs zeer waarschijnlijk is, zullen de analyses uit hoofdstuk 7 duidelijk maken.

- Als laatste opvallende bevinding betreffende het behandelingsproces van $Z$-Limburgse patiënten is vastgesteld, dat de wachttijd voor ziekenhuisopname in deze regio (1980/81) langer duurt dan in de Randstad (1974/75).

Vermoedelijk moet men de oorzaken van de $Z$-Limburgse langere wachttijden voor ziekenhuisopname zoeken in de hogere opnamecoëfficiënt in deze regio. In Limburg werden bijvoorbeeld in 197711.6 patiënten per 100 inwoners opgenomen, tegenover respectievelijk 11.1 en 10.1 in $\mathbb{N}-$ en $z$-Holland in 1975 (Lisz-jaarverslag). De alternatieve verklaring, uitgaande van de opnameduur, gaat niet op. aangezien deze in z-Limburg (1981) korter is dan in de Randstad (1975) (zie ook dit onderzoek). Er vinden dus echter wel meer opnamen plaats; deze zijn op hun beurt warschijnlijk weer het gevolg van de slechtere gezondheidstoestand van de z-Limburgse bevolking, zoals beschreven in soeters (1980a en $b$ ) en op onderdelen bevestigd door Hoogendoorn (1982) en Knibbe (1982). 


\subsection{Samenvatting}

In dit hoofdstuk is op kwantitatieve wijze beschreven, welke "procesgang" langdurig zieke werknemers doox de gezondheidszorg maken. Hierbij is steeds een vergelijking gemaakt met het onderzoek van Tordoir c.s., waarin dezelfde gegevens voor de Randstad in de jaren 1974-75 verzameld zijn.

In vergelijking met deze Randstadgegevens is gebleken, dat in de z-Limburgse steekproef van langdurig zieke werknemers $(>6$ weken $)$ :

- het behandelingsproces snellex begint, omdat de eerste contacten snellex na datum ziekmelding plaatsvinden;

- er lets meer contacten met de gezondheidszorg plaatsvinden, vooral met de fyslotherapeut en de eventueel aanwezige bedrijfsarts;

- de (GAK-)VG lets later en in het algemeen minder vaak optreedt en minder direct is met zijn aanwijzingen omtrent verzuimcontinuering $\mathrm{c} \cdot \mathrm{q}$. werkhervatting;

- het netto-wachttijdpercentage voor de z-Limburgse GAKverzekerden vrijwel even hoog is, terwijl het voor leeftijdsverschillen gecorrigeerde netto percentage wachttijd ruim 2.58 hoger is en in $z$-Limburg 22,18 bedraagt; hierbij concentreren de z-Limburgse wachttijdproblemen zich in hoofdzaak rondom ziekenhuisopnamen de zgn. stuurloze perioden;

- evenals in het Randstad-onderzoek de verwijzingen naar orthopaeden en rheumatologen het langst van alle specialistenverwijzingen duren, op afstand gevolgd door de verwijzingen naar neurologen en internisten;

- evenals in het Randstad onderzoek, de latere niet-hervatters in vrijwel alle opzichten meer wachttijden meemaken dan de hervatters.

Ter interpretatie van deze resultaten is ten eerste vastgeste1d, dat het aanbod van gezondheidszorgvoorzieningen voor beide vergelijkingsmomenten ( $\mathrm{z}$-Limburg: 1981 - Randstad: 1975) ongeveer gelijk is ontwikkeld. De verschillen, die er tussen beide onderzoeken zijn, moeten dan ook overwegend aan het volgende worden toegeschreven: 
- de iets intensievere patiënt-gezondheidszorg-interactie in de $z$-Limburgse steekproef heeft vermoedelijk te maken met de oververtegenwoordiging van aandoeningen aan het bewegingsapparaat in de steekproef (invloed van fysiotherapie) en met de toegenomen sociale controle ten opzichte van ziekteverzuim.

- de omvangrijkere stuurloze periode in de z-Limburgse steekproef is mogelijk het gevolg van de lets minder vaak en minder direct optredende $\mathrm{z}$-Limburgse (GAK-) VG-en. Dit geldt in het bijzonder voor dat deel van de steekproef, dat uitsluitend uit GAK-verzekerden bestaat. Maar mogelijk zijn de langere stuurloze perioden van GAK-verzekerden mede een gevolg van een andere samenstelling van het patiëntenbestand.

- de relatief lange wachttijden voor ziekenhuisopname zijn waarschijnlijk het gevolg van de hogere opnamecoëfficiënt in z-Iimburg, die op zijn beurt weex het gevolg is van de slechtere gezondheidstoestand van de z-Limburgse bevolking.

Tot besluit is in dit hoofdstuk de indruk ontstaan, dat VGen in hun verzuimbegeleiding verschillend opereren, al naar gelang de organisatorische context, warin zij werkzaam zijn. Zo zijn er o.a. verschillen geconstateerd in de frequentie van contacten tussen VG-en en verzekerden, en in de wijze, waarop vervolgcontacten tot stand komen. 
HOOFDSTUK 5.

DE WERKHERVATTING.

5.1. Inleiding

Na het voorgaande hoofdstuk over de ervaringen van de langdurig zieke werknemers in de gezondheidszorg komt nu het werkhervattingsproces in beeld. Dit onderwerp is weinig beschreven en dan nog alleen voor een enkele diagnosecategorie (Diederiks, 1982). Dit mag merkwaardig heten, ondat de manier, waarop de reintegratie in het arbeidsproces verloopt, in belangrijke mate medebepalend is voor de duur en afloop van de ziekteperiode.

Zo heeft Philipsen (1969a) erop gewezen, dat patiënten een zekere, zij het per ziektegeval variërende, mate van beslissingsvrijheid ten aanzien van het moment van werkhervatting hebben. Aan de andere kant kan ook de sociaal-medische begeleiding van zieke werknemers door functionarissen van uitkerings- en/of controlerende instanties witeenlopen (Eunfeld, 1980, van zaal, 1981). Tenslotte kan de ziektebegelelding van de kant van het bedrijf of de instelling, waar de patiënt werkzaam is, sterk variëren (bv. Rlis, 1978). Onvermijdelijk leiden deze omstandigheden tot verschillen in de duur en afloop van ziektegevalien.

Om deze reden wordt in dit hoofdstuk op het werkhervattingsproces ingegaan. Om te beginnen wordt in par. 5.2 het resultaat van de werkhervatting, met andere woorden de situatie aan het einde van de onderzoeksperiode beschreven. Eveneens wordt in deze paragraaf enige aandacht besteed aan het proces, dat tot dit resultaat geleid heeft. Aan de orde komt de vraag, op wiens advies de zleke werknemers het werk hervat hebben.

Een factor, die in het werkhervattingsproces een prominente rol speelt, wordt vervolgens in par. 5.3 apart belicht. Het betreft de mogelijkheid tot het scheppen van of zoeken naar aangepaste arbeid; dit om zieke werknemers ook bij gedeeltelijke arbeldsongeschiktheid (weer) te kunnen laten werken. Deze kwestle wordt hier apart behandeld, omdat men van vele kanten grote betekenis hecht aan een beleidsprogramma, dat gericht is "op het zolang mogelijk vasthouden van potentiële 
arbeidsongeschikten in het arbeidsproces" (Bax, 1982). Dit blijkt $0 . a$. uit het feit, dat over dit onderwerp een nieuwe wet in aankomst is: bedoeld is de Wet Arbeid Gehandicapte Werknemers, de WAGW (bv. SER-advies, 1982).

In de voorlaatste paragraaf van dit hoofdstuk komt dan de patiënt zelf aan het woord. zijn subjectieve oordeel over de al dan niet gelukte werkhervatting wordt besproken. Het is belangrijk om hiervan kennis te nemen, ondat het bij ziekteverzuimbeleid altijd een precair balanceren is tussen het kostenmotief en het menselijk of patiëntenbelang (par. 5.4). Een samenvatting van het voorgaande sluit het hoofdstuk af (par. 5.5).

\subsection{Werkhervatting of arbeidsongeschikt?}

Allereerst beschrijven wij nu de situatie aan het einde van de onderzoeksperiode.

Schema 5.1.

Beschrijving van de onderzoeksgroep bij het einde van de onderzoeksperiode.

volledig hervat

inclusief 6 personen, die een part-time dienstverband voor de ziekteperiode hadden.

Zoals schema 5.1 laat zien, heeft bijna driekwart van de onderzoekspersonen het werk normaal en binnen een kalenderjaar na ziekmelding hervat. Nog eens 138 hervat ook binmen het jaar, maar doet dat -in eerste instantie of definitief- op deeltijdbasis. Bij hen is dus sprake van aangepast werk, zij het, dat het hier uitsluitend gaat on een wijziging in de 
werktijdfactor (zie verdex par. 5.3). In total hervat dus 878, dit is precies evenveel als in het onderzoek van Tordolr c.s. (1978). Voor $11 \%$ van de steekproef treedt de WAO, het Invaliaiteitspensioen (voor ambtenaren) of enigerlei vUT-regeling in werking. Dat is ruim $1 \%$ minder dan in het onderzoek van Tordoir. Dit verschil is verwaarloosbaar klein, zeker in relatie tot het feit, dat de Z-Limburgse steekproef gemiddeld jonger is en beduidend minder 55-plussers telt. Bovendien heeft de $\mathrm{z}$-Limburgse steekproef ook betrekking op overheidsambtenaren, een werknemerscategorie met een duldelijk lager invalideringsrisico (v.d. Bosch \& Petersen, 1980). Op grond van deze kenmerken zou men een belangrijk kleiner aantal arbeidsongeschikten in de z-Limburgse steekproef hebben kunnen verwachten. Dat dit niet het geval is, moet men verklaren uit de al jarenlang grotere WAOinstroom in z-Limburg (Soeters, $1980 \mathrm{a}$ en b) en uit de sinds 1974 in het algemeen toegenomen WAO-intrede. Om dezelfde redenen -minder 55-plussers, en ambtenaren in de steekproefis de gemiddelde ziekteduur van dit onderzoek ook nagenoeg gelijk aan die in het onderzoek van Tordoir c.s.(1978), terwijl al langer bekend is, dat de $z$-Limburgse ziekteduren in feite langer zijn dan elders in het land.

Tenslotte is bij 3 respondenten het onderzoek afgesloten op het moment, dat de zilekte-uitkering werd stopgezet of ontslag werd aangezegd.

In tabel 5.1 wordt nu nagegaan, of er factoren zijn, die verband houden met de situatie aan het einde van de onderzoeksperiode. 
Tabel 5.1.

Enkelvoudige variantie-analyses; situatie aan elnde onderzoeksperiode tegen leeftijd, beroepsnivo, gezondheidsperceptie en ziekteduur.

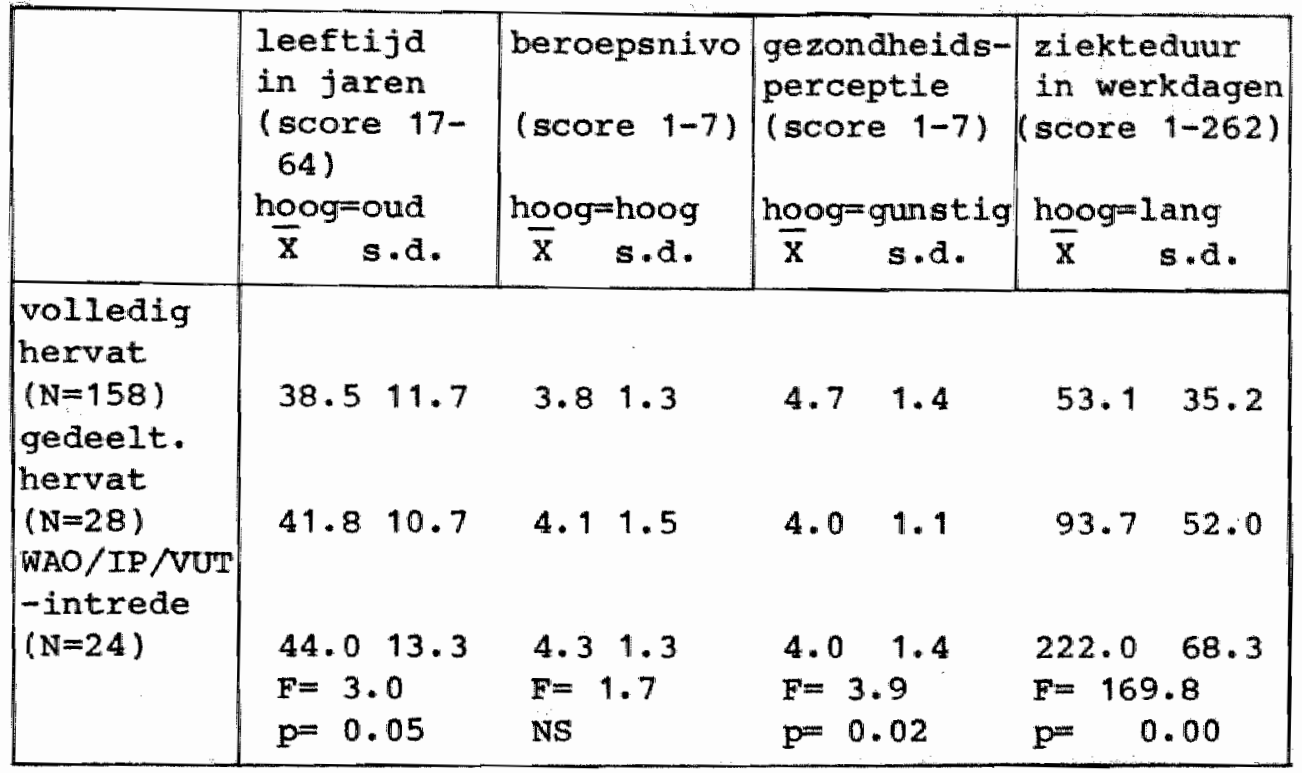

Tabel 5.1 wijst ten eerste uit, dat degenen die volledig hervat hebben, ook gemiddeld de jongste leeftijd hebben. Degenen, die in het geheel niet hervatten, zijn het oudst. Dit significant resultaat beantwoordt aan het al vele malen bevestigde inzicht, dat met de jaren de (ernstigere) gebreken komen en de kans op arbeidsongeschiktheid toeneemt (bv. Herwifer, 1981). Een tweede significante bevinding betreft de relatie tussen de situatie aan het einde van de onderzoeksperiode en de gezondheidsperceptie. Deze variabele vormt het oordeel van de respondenten over hun gezondheldstoestand ten tijde van het eerste interview. Dit oordeel blijkt een redelijke voorspeller te zijn, aangezien de volledige hervatters op deze variabele duldelijk gunstiger hebben gescoord dan de andere respondentcategorieën. Deze bevinding komt overeen met die van wersma (1979) en MerensRiedstra (1981), en met hetgeen in de literatuur bekend is over hartinfarctpatiënten (Diederiks, 1982). Mogelijk, maar niet zeker, vormt de gezondheidsperceptie een goede indicatie van de exnst van de aandoening.

Een derde significant verband spreekt voor zich: volledige 
hervatters hebben gemiddeld de kortste ziekteduur, terwij1 degenen, die (voorlopig) gedeeltelijk hervatten op hun beurt gemidald korter verzuimen dan de WAO-ers.

Tenslotte de vierde en laatste variabele: het beroepsnivo. Deze variabele is gecreêerd door aan de functies van de respondenten een nivo-score toe te kennen op basis van de ITSberoeperklapper (1975). In deze nivo-score wordt aangegeven, hoeveel verstandelijke aanleg voor de betreffende functies vereist is. Deze variabele is in onze steekproef niet significant gerelateerd aan de situatie aan het einde van de onderzoeksperiode. Bovendien kont de richting van de uitkomsten niet overeen met de bestaande kennis omtrent de invaliderings- en ziekteverzuimkans van beroepscategorieën ( $b v$. GMD-jaarverslag, 1979; Bax, 1982; Nijhuis en soeters, 1982): de niet-hervatters blijken namelijk -in tegenstelling tot wat gebruikelijk is-gemiddeld het hoogste beroepsnivo te hebben. Ook bif controle op eventuele interactie-effecten met leeftijd en gezondheidsperceptie blijkt de beroepsnivovarlabele geen duidelijk en verwacht verband met de situatie aan het einde van de periode op te leveren. Dit resultaat komt overigens wel overeen met dat van wiersma (1979). Kennelijk zijn onder de patiënten in onze steekproef met hogere beroepsnivo's meer ernstig zieken en/of meer vUT-gevallen vertegenwoordigd. Dit is in feite niet zo onbegrijpelijk, omdat het hier een steekproef van langdurig zieken betreft. Wanneer immers de kans op langdurige ziekte voor hogere beroepsnivo's geringer is, is het waarschijnlijker, dat men bij het aantreffen van langdurig zieke hogere beroepsoefenaren ook met ernstigere gevalien te maken heeft.

Het ontbreken van een significante relatie tussen beroepsnivo en al dan niet werkhervatten zet zich voort, als het gaat om het verklaren van verschillen in ziekteduur. Tabel 5.2 geeft een overzicht van drie enkelvoudige variantie-analyses van de zilekteduur tegen de basiskenmerken leeftijd, beroepsnivo en gezondheidsperceptie. 
Tabel 5.2.

Enkelvoudige variantie-analyses, ziekteduur in werkdagen tegen leeftijd, beroepsnivo en gezondheidsperceptie.

\begin{tabular}{|c|c|c|c|c|c|c|c|c|}
\hline \multicolumn{3}{|l|}{ leeftijd } & \multicolumn{3}{|c|}{ beroepsnivo } & \multicolumn{3}{|c|}{ gezondheidspercep- } \\
\hline & $\overline{\mathrm{x}}$ & s.d. & $\overline{\mathrm{x}}$ & $5 . a$ & & tie & $\bar{x}$ & s.d. \\
\hline $15 \operatorname{tm} 24 j x$ & 54.9 & 45.1 & $1=$ laag & 92.3 & 62.4 & $1=$ ongunst & 94.8 & 93.9 \\
\hline $25 \mathrm{tm} 34 \mathrm{j} x$ & 74.8 & 66.4 & $2=$ & 83.3 & 70.8 & $2=$ & 103.3 & 88.4 \\
\hline $35 \mathrm{tm} 44 \mathrm{jr}$ & 78.3 & 62.6 & $3=$ & 66.0 & 69.2 & $3=$ & 103.3 & 76.2 \\
\hline 45 tm $54 j x$ & 94.4 & 85.2 & $4=$ & 67.6 & 62.6 & $4=$ & 76.1 & 61.6 \\
\hline \multirow[t]{4}{*}{$55 \mathrm{tm}$} & 90.7 & 81.1 & $5=$ & 95.3 & 75.2 & $5=$ & 80.9 & 72.5 \\
\hline & & & $6=$ & 103.1 & 86.5 & $6=$ & 56.6 & 59.6 \\
\hline & & & $7=$ hoog & 38.2 & 31.3 & $7=$ gunstig & 53.8 & 55.0 \\
\hline & $=1.5$, & N.S. & & $=1.7$, & N.S. & & $2,2, p$ & .05 \\
\hline
\end{tabular}

Het blijkt, dat de voor de gehele steekproef geldende gemiddelde ziekteduur van bijna 16 weken $(=79$ werkdagen), niet significant en eenduldig varieert met het beroepsnivo. Dit resultaat blijft, evenals overigens het voorgaande resultaat met beroepsnivo, onveranderd, wanneer men het beroepsnivo vervangt door het opleidingsnivo van de respondenten. Opnieuw stemt deze bevinding overeen met het onderzoek van wiersma (1979). Kennelijk is in een steekproef van patiënten de ernst $\operatorname{van}$ de aandoening en niet het beroepsnivo de doorslaggevende factor (zie verder voor dit verschijnsel: hoofdstuk 8).

Niet significant, maar wel eenduidig en volgens verwachting stijgt de gemiddelde ziekteduur met de leeftijd (vgl. voor eenzelfde resultaat bv. Luyckx, 1982). Tenslotte blijkt de gezondheidsperceptie ook hier weer een goede voorspeller van de uiteindelijke ziekteduur: hoe gunstiger men tijdens het eerste interview over zijn of haar eigen gezondheid heeft geoordeeld, des te korter is de uiteindelijke ziekteduur.

Tot zover het overzicht van de stand van zaken aan het einde van de ziekte-/ZW-periode en van enkele daarmee verband houdende factoren. Tot slot van deze paragraaf willen wij nog ingaan op de vraag, op wiens advies de werkhervatting heeft plaatsgevonden.

Ruim de helft van de herstelden (548) heeft het werk hervat op aanwijzing van de VG, terwijl 398 zegt op eigen initiatief weer te zijn gaan werken (Randstad: resp. 60 en 22\%). 
De behandelende hulpverlener heeft slechts in $5 \%$ van de gevallen het advies tot werkhervatting gegeven en speelt in dit verband dus een zeer ondergeschikte rol (zie ook tabel 4.10 in de bijlage). Dit blijkt bijvoorbeeld cok uit het feit, dat de behandelaar in bijna 40 s van alle werkhervattingsgevallen hiervan nlet op de hoogte is.

voor de aard van de werkhervatting -volledig of gedeeltelijk- makkt het in het geheel niet uit, of de werkhervatting plaats vindt op aanwijzing van de VG of op eigen initiatief van de patiënt $(\times 2=3.0$, N.S. $)$.

5.3. Onderhandelingen over aanpassingen in het werk.

In de inleiding van dit hoofdstuk is al gewezen op het belang van aangepaste arbeld voor de beperking van langdurig zilekteverzuim en arbeidsongeschiktheid. Het ontbreken ervan is wel het knelpunt van de arbeidsongeschiktheidswetten genoemd (Zweekhorst, 1977). Ter illustratie hiervan: onlangs is vastgesteld, dat van degenen, die in 1980 tot de WAO toetraden minstens 298, maar warschijnlijker zelfs $48 \%$ na verloop van tijd nog passend werk zou kunnen verrichten (Aarts, Bruinsma en de Jong, 1982a).

Tegen de achtergrond van dit toch wel onthutsende verschijnsel valt een recente en geleidelijke verandering te signaleren van de wijze, warop arbeidsprestaties worden gedefinieerd. Juist in tijden van economische crisis -zoals nuraakt de aandacht van werkgevers steeds meer gericht op een optimale benutting van de arbeldsfactor (Schultz-wild, 1978). Als gevolg hiervan is een tendens tot intensivering van de arbeid gesignaleerd; deze veroorzaakt, dat werknemers met relatief geringere aandoeningen, niet meer kunnen voldoen aan de veranderende prestatie-eisen (uitgebreider hierover: Nijhuls en Soeters, 1982, soeters, 1983). Bij gebrek aan werk, dat overeenkomt met hun zgn. "restcapaciteit" vormt een volledige arbeidsongeschiktheidsverklaring dan nog vak de enige -matschappelijk gelegitimeerde- uitweg. Overigens is dit probleem niet helemal van vandaag of gisteren. Ook in de tijd van de Interimwet Invaliditeitsrentetrekkers werd dit probleem als corzaak van arbeidsongeschiktheid gesignaleerd (Aling, 1969).

Onmiddellijk rijst hierbij de vraag, waarom het dan kenne- 
lijk zo moeilijk is, om het eigen werk aangepast te krijgen of andere passende arbeid te vinden. Het weinige, dat hierover bekend is, wijst erop, dat werkgevers met betrekking tot het creëren van aangepaste functies een grotere bereldheid uitspreken dan daadwerkelijk aan de dag leggen (Nagi, McBroom en Colette, 1969). Bovendien lijkt deze bereidheid te fluctueren met de spanning op de arbeidsmarkt (Leviton en Taggart, 1977). Van werkgeverszijde wordt minstens een viertal bezwaren aangevoerd tegen het in dienst houden of nemen van partieel gehandicapten:

- ze zouden langere opleidings- en inwerktijden nodig hebben,

- in het algemeen zouden ze minder efficiënt produceren,

- de fysieke werkomgeving zou voor hen vaker aangepast moeten worden,

- ze zouden een grotere risicofactor in verband met ziekteverzuim vormen (Nagi et al, 1969).

Hoe steekhoudend deze argumenten zijn, is nog lang geen uitgemaakte zaak (Dijkstra, 1979). Feit is wel, dat het beschikbare aantal aangepaste functies sterk achterblijft bij de (maatschappelijke) behoefte eraan. Een nieuw wetsontwerp (WAGW) waarmee werkgevers verplicht worden een bepaald percentage gedeeltelijk gehandicapten in dienst te nemen of te houden, illustreert dat (SER-advies, 1982).

Dit alles vormt de aanleiding tot deze paragraaf. Aan de respondenten uit dit onderzoek is namelijk gevraagd, of het onderwerp "aangepaste arbeid bij de eigen werkgever" op enig moment tijdens de ziekteperiode met iemand besproken is. Tabel 5.3 bevat het antwoord.

Tabel 5.3 .

Gesprek over aanpassingen in het werk voor werkhervatters en niet-werkhervatters.

\begin{tabular}{|l|rlrl|rl|}
\hline & \multicolumn{2}{|c|}{ hervat } & niet hervat & totaal \\
\hline gesprek & 65 & $(358)$ & 14 & $(588)$ & 79 & $(378)$ \\
geen gesprek & 121 & $(658)$ & 10 & $(428)$ & 131 & $(638)$ \\
Totaal & 186 & $(1008)$ & 24 & $(1008)$ & $\mathbf{2 1 0}(1008)$ \\
\hline
\end{tabular}

$x^{2}=5,75$

$\mathrm{p}<0.02$

* exclusief de 3 respondenten die ontslagen zijn. 
Ruim 1/3 gedeelte van de hervatters heeft op enigerlei moment met lemand gesproken over eventuele aanpassingen in het eigen werk. Degenen, die ulteindelijk arbeidsongeschikt zijn geworden of vervroegd gepensioneerd $z i j n$, hebben significant vaker zo'n gesprek gevoerd. Bovendien hebben de niet-hervatters, die tenminste één gesprek gehad hebben, gemiddeld meer gesprekken gevoerd dan de hervatters, die over werkaanpassing onderhandeld hebben (resp. 3.9 versus 2.3 gesprekken per betreffende respondent). Deze uitkomsten zijn niet verwondexlijk, gezien de grote betekenis, die aangepaste arbeid voor het arbeidsongeschiktheldsprobleem heeft, zoals al zojuist werd aangeduid. Verder zal het ook geen verbazing wekken, dat de 28 respondenten, die gedeeltelijk hervat hebben, allen een gesprek over werkaanpassing hebben gehad.

Over de vraag met wie men een gesprek over werkaanpassing gevoerd heeft, verschaft tabel 5.4 in de bijlage nadere informatie.

Naast de familie -bekend als raadgever in kwesties rondom zlekte (Mootz, 1981)- fungeert de VG in de meeste gevalien als gesprekspartner in dezen. Verder heeft men ook relatief vaak gesproken met de $B A$ ( $B A / V G$ ), met de directe werkbaas, chef of directie en met de behandelende hulpverlener. Vooxtvloeiend uit de procedures, die gelden bij de toepassing van de arbeidsongeschiktheidswetten, hebben de niet-hervatters significant vaker gesproken met artsen en arbeidsdeskundigen van de GMD of het ABP. Bovendien hebben de niet-hervatters lets vaker met hun behandelend(e) arts(en) over dit onderwerp gesproken. Kennelijk vormt de aard en de ernst van hun aandoening voor deze respondenten vaker een doorslaggevende succes- of faalfactor dan voor de uiteindelijke herstelde respondenten, die over werkaanpassing gesproken hebben. Met betrekking tot de vraag, op wiens initiatief het onderhandelingsproces over werkaanpassingen op gang komt, bevat tabel 5.5 de noodzakelijke informatie. De meeste respondenten nemen zelf het initiatief hiertoe (438), terwijl in ruim $1 / 5$ deel van de gevallen de VG het onderhandelingsproces start. Bij de niet-hervatters nemen de VG en de behandelend(e) arts(en) vaker het voortouw dan bij de uiteindelijke hervatters. Bij de hervatters is duidelijk, zij het niet significant, vaker sprake van een eigen initiatief van de patiënt. Dit suggereert, dat de uiteindelijk herstelden tijdens het ziekteverloop de mogelijkheid van een werkaanpassing optimistischer inschatten dan de latere arbeidsonge- 
schikten. Mogelijkerwijze zijn zij ook gemotiveerder, an weer aan de slag te gaan. Deze indruk wordt versterkt door het feit, dat maar liefst 16 van de 28 gedeeltelijke hervatters $(=578)$ het onderwerp "werkaanpassing" zelf hebben aangekaart.

Tabel 5.5 .

Initiatief tot gesprek over aanpassingen in het werk, voor hervatters en niet-hervatters.

\begin{tabular}{|l|rlrl|ll|}
\hline & \multicolumn{2}{|l}{ hervat } & niet-hervat & totaal \\
\hline VG van GAK/BV & 13 & $(218)$ & 5 & $(368)$ & 18 & $(238)$ \\
HA/specialist & 8 & $(138)$ & 3 & $(218)$ & 11 & $(148)$ \\
eigen initiatief & 32 & $(498)$ & 3 & $(228)$ & 35 & $(438)$ \\
anders & 12 & $(188)$ & 3 & $(218)$ & 15 & $(208)$ \\
Totaal & 65 & $(1008)$ & 14 & $(1008)$ & 79 & $(1008)$ \\
\hline
\end{tabular}

$x_{2}=3.59$

N.S.

$\mathrm{Na}$ dit alles rijst vanzelfsprekend de vraag, hoe vaak het nu daadwerkelijk tot een werkhervatting met aanpassing is gekomen. Van de 186 herstelde respondenten hebben er in totaal $39(=218)$. met een of andere -definitieve of tijdelijkewerkaanpassing hervat. Behalve de 28 respondenten, bij wie in ieder geval de werktijdfactor is aangepast (zie begin van dit hoofdstuk), zijn er dus nog 11 respondenten weer gaan werken met één of meer andere werkaanpassing(en). Van de hervatters, die tijdens hun ziekteperiode over werkaanpassing gesproken hebben, heeft dus in total $608(39 / 65) \mathrm{zijn}$ doel bereikt. Bij de overigen is dit dus niet het geval geweest. De reden hiervan staat vermeld in overzicht 1. 
Overzicht 5.1 .

Resultaat van onderhandelingsproces over werkaanpassing, voor hervatters en niet-hervatters.

\begin{tabular}{|c|c|c|c|}
\hline hervat & & niet hervat & \\
\hline $\begin{array}{l}\text { werkaanpassing } \\
\text { gelukt }\end{array}$ & $39(608)$ & $\begin{array}{l}\text { geen werkaanpassing } \\
\text { vanwege ernst aan- } \\
\text { doening }\end{array}$ & $4(288)$ \\
\hline $\begin{array}{l}\text { werkaanpassing } \\
\text { njet meer nodig } \\
\text { vanwege gunstig } \\
\text { verloop ziekte }\end{array}$ & $9(148)$ & $\begin{array}{l}\text { geen werkaanpassing } \\
\text { nodig vanwege leef- } \\
\text { tljd (vUT) }\end{array}$ & $6(438)$ \\
\hline $\begin{array}{l}\text { werkaanpassing } \\
\text { kon in bedrijf } \\
\text { niet gerealiseerd } \\
\text { worden }\end{array}$ & $17(268)$ & $\begin{array}{l}\text { werkaanpassing kon } \\
\text { in bedrijf niet ge- } \\
\text { realiseerd worden }\end{array}$ & $4(298)$ \\
\hline Totaal & $65(1008)$ & & $14(1008)$ \\
\hline
\end{tabular}

Het blijkt, dat bij 148 van de hervattende respondenten de noodzaak tot werkaanpassing is komen te vervallen wegens een gunstig verloop van de ziekte. De overige 17 respondenten (268) hebben het werk normaal hervat, ondanks het felt, dat een noodzakelijk geachte aanpassing op de werkplek niet gerealiseerd kon worden. Van alle herstelde respondenten in de totale steekproef (186) bedragt dit antal 98. Het 1igt voor de hand te veronderstellen, dat juist deze werknemers -objectief en subjectief- reden hebben, am zich opnieuw ziek te melden.

Dan de nlet-hervatters. Van deze categorle vermelden 5 respondenten $(5 / 24=21 \%)$, dat de werkhervatting mislukt is, enkel en alleen, ondat er door het bedrijf of de instelling, waar men werkzaam was, geen werkaanpassing mogelijk werd gemaakt.

Veelbetekenender dan de problematiek van deze 5 respondenten is wellicht nog het feit, dat 10 van de 24 niet-hervatters (= 428) bij hun overgang naar de WAO/IP te kennen hebben gegeven, wel tot werken in staat te zijn. Slechts de helft van de 24 niet-hervatters heeft in dit opzicht uitdrukkelijk negatlef geantwoord. Ofschoon het aantal niet-hervatters uit 
onze steekproef in absolute zin klein is, signaleren wij hier aan de hand van het oordeel van de werknemers hetzelfde probleem als Aarts e.a. (1982a) deden met behulp van schattingen van GMD-artsen en -arbeidsdeskundigen. Uit de resultaten van beide onderzoeken blijkt duidelijk, dat het ontbreken van passende arbeid -met name ook bij de eigen organisatie- een zeer belangrijke factor is bij het ontstaan van arbeidsongeschiktheid.

Terug naar de wel gelukte werkaanpassingen. Deze werkaanpassingen bij-zoals gezegd- 39 respondenten zijn inhoudelijk als volgt in te delen (meerdere aanpassingen konden worden genoemd) :

- andere werktijden en/of gedeeltelijke werkhervatting

- lichtere minder inspannend werk (maar

in feite derelfde functie-inhoud)

$30(458)$

- werk in andere ruimtes

- werk met andere collega's

- langzamer arbeidstempo

- geen ploegendienst en anders

Totaal

$\begin{array}{rr}11 & (178) \\ 7 & (118) \\ 6 & (198) \\ 5 & (188) \\ 5 & (188) \\ 2 & (28) \\ 66 & (1008)\end{array}$

Te zien valt, dat de meeste aanpassingen een verandering van werktijden betreffen; overwegend gaat het hiex on werkhervattingen op deeltijabasis (zie begin van ait hoofdstuk). In ruim $3 / 4$ deel (778) van de 30 gevallen met zo'n werktijdaanpassing is uitsluitend sprake van deze ene verandering. Hilermee wordt treffend geillustreerd, dat deeltijdarbeld een belangrijke factor kan zijn bij de beperking van het ziekteverzuim- en arbeidsongeschiktheidsprobleem (soeters, 1978; Diederiks, 1982).

Van alle 39 personen, die met werkaanpassingen hebben hervat, is trouwens bij 27 gevallen ( $=69 \%)$ sprake van slechts één enkele verandering (zie tabel 5.6 in de bijlage). Hier komt bij, dat slechts ruim 108 van alle werkaanpassingen voor definitief bedoeld zijn. De combinatie van beide kenmerken (608) suggereert, dat de hier gerealiseerde werkaanpassingen overwegend licht zijn en zonder al teveel gevolgen op het organisatorische vlak voor de betxeffende bedrijuen en instellingen.

Toch zijn deze werkaanpassingen voor de zleke werknemers in 
kwestie ruim voldoende geweest: drlekwart van de 39 personen die hun werk met aanpassing hervat hebben, is hierover (zeer) tevreden, terwijl slechts 8 hierover ontevredenheid ult (zie tabel 5.6 in de bijlage). Of met deze werkaanpassingen ook de medeoorzaken van de ziekte verdwenen zijn, is lets anders. Voor $1 / 3$ deel wan desbetreffende respondenten is deze vraag niet aan de orde, aangezien hun arbeidssituatie geen invioed heeft gehad op het ontstaan van de aandoening. Van de overige 26 respondenten, die met een aanpassing hun werk hervat hebben, beweert 318 ( 8 personen) tegenover $46 \%$ ( 12 personen), dat de werkaanpassing in dit opzicht wel respectievelijk niet voldoende is geweest. Naast de al eerder gesignaleerde 17 respondenten, die zonder de noodzakelijke geachte werkaanpassing hervat hebben, treffen wij met deze laatste 12 personen opnieuw een categorie respondenten aan, voor wie de werkhervatting geen volledige oplossing voor het ziekteprobleem heeft betekend.

\subsection{Het subjectief herstel.}

In de vorige paragrafen is over werkhervatting geschreven als een indicator voor objectief herstel van de ziekte. Daarmee is nog niets gezegd over het subjectief herstel, met andere woorden, het herstel in de ogen van de patiënten zelf. Deze twee criteria vallen niet noodzakelijk samen. zo blifken 30 van de 117 regpondenten $(=268)$, die het werk op aanwijzing van -doorgaans- de VG hebben hervat, het daarmee niet eens te zijn geweest (voor alle 186 hervatters bedraagt dit 168). Hier is dus sprake van een werkhervatting tegen de zin van de patiënt zelf. Het moment van werkhervatting vormt dan het twistpunt: 29 van deze respondenten (ofwel 939) blijkt dat tifdstip te vroeg te vinden $\left(X_{2}=94,7\right.$, $\mathrm{p}=0.05$ ).

Van deze 29 respondenten zijn er 8 , die ook al het werk zonder noodzakelijk geachte werkaanpassing hebben hervat. van de 21 anderen zijn ex nog 3 , die behoren tot de 12 personeelsleden, voor wie de gerealiseerde werkaanpassing niet voldoende was, on de oorzaken van de ziekte te doen verdwijnen. Met de resterende groep van 18 respondenten, die uitsluitend vonden dat ze weer te vroeg aan de slag moesten, hebben wij dus een derde categorie hervatters geïdentifi- 
ceerd, voor wie de werkhervatting niet als volledig geslaagd te kwalificeren valt.

Toch zijn er cok meer positieve geluiden te signaleren. van alle hervatters is namelijk de overgrote meerderheid (828) van mening, dat het tijdstip van werkhervatten juist goed is; zoals gezegd, vindt $16 \%$ van de hervatters dit tijdstip te vroeg, terwijl slechts 3 respondenten (2\%) juist vindt, dat men al eerder aan de slag had kunnen gaan.

Het laatste woord in deze paragraaf geldt de niet-hervatters. Hun oordeel over hun toekomst in de betaalde arbeid is overwegend negatief: 13 respondenten $(=548)$ beschouwen hun arbeidsleven als beëindigd; hieronder zijn vanzelfsprekend de vuTters en de ouderen te vinden. Verder zijn 8 respondenten $(=33 \%$ ) uitgesproken somber en pessimistisch, en wel met name over de mogelijkheid on ander passend werk te krijgen. Tenslotte zien 3 respondenten (13\%) de arbeidstoekomst juist zonnig tegemoet: zij verwachten op afzienbare termijn weer aan de slag te kunnen.

5.5. Samenvatting

In dit hoofdstuk is het proces van werkhervatten beschreven. Gebleken is, dat $87 \%$ van dẹ respondenten hun eigen werk weer volledig of gedeeltelijk hebben hervat. In vergelijking met de overigen, die arbeidsongeschikt zijn geworden, zijn zij gemiddeld jonger en hebben $z i j$ een gunstigex perceptie omtrent de ernst van hun aandoening. Vanzelfsprekend zijn zij gemiddeld ook korter ziek.

Van de hervatters is ruim de helft weer gaan werken op aanwijzing van de VG, terwijl bijna $40 \%$ op eigen initiatief hervat heeft. De behandelende hulpverlener speelt in dit opzicht een ondergeschikte rol.

Ruim $1 / 3$ gedeelte van alle respondenten heeft op enig moment tijdens de ziekteperiode met iemand gesproken over mogelijkheden, om aangepaste arbeid te verkrijgen. Behalve met de familie hebben deze respondenten hierover meestal met de VG of $\mathrm{BA}$ gesproken. De behandelende arts speelt in dit verband eveneens geen onbelangrijke rol, zeker niet bij de later arbeidsongeschikt geworden respondenten.

Uiteindelijk hebben 39 respondenten $(=248)$ hun werk hervat 
met een of andere -definitieve of tijdelijke- werkaanpassing. Het betreft doorgaans een tijdelijke verandering van de werktijdfactor.

Van de niet-hervatters wijten 5 respondenten $(5 / 24=218)$ het mislukken van de reIntegratie in het arbeidsproces aan de niet gerealiseerde werkaanpassing. Opvallend genoeg, hebben 10 van de 24 nilet-hervatters te kennen gegeven, dat zij-ofschoon arbeidsongeschikt verklaard- wel tot werken in staat zijn. Gevraagd naar hun toekomstperspectief zijn marar 3 respondenten uit de niet-hervattersgroep optimistisch; de rest (=88\%) verwacht hetzij wegens de hoge leeftijd, hetzij wegens het gebrek aan passend werk arbeidsongeschikt te blijven.

Tenslotte zijn in dit hoofdstuk 3 categorieën respondenten onderscheiden, voor wie de werkhervatting niet volledig geslaagd te noemen is:

- 17 respondenten $(17 / 186=98)$, wier verzoek tot werkaanpassing niet gerealiseerd kon worden; 8 van hen vonden bovendien, dat ze weer te vroeg aan de slag moesten,

- 12 respondenten $(=6 \%)$, wler wel gelukte werkaanpassing de oorzaken van hun ziekte of aandoening volgens hun zeggen niet wegnam; van deze groep vonden 3 werknemers ook nog, dat ze te snel moesten hervatten

- 18 respondenten $(18 / 186=10 \%)$, voor wie uitsluitend het tijdstip van werkhervatting te vroeg was.

Al met al blijkt een kwart van alle werkhervattingen niet tot tevredenheid van de werknemers te $\mathrm{zijn}$ verlopen. 
HOOFDSTUK 6.

DE VARIABELEN BESCHREVEN.

6.1. Inleiding

Na de beschrijvende hoofdstukken 4 en 5 willen wij in het vervolg van deze studie de wachttijden en ziekteduren aan nadere analyse onderwerpen. Hiermee komen wij aan het verklarende deel van deze studie. Dit is het gedeelte, dat vanuit het oogpunt van representativiteit niet alleen van betekenis is voor z-Limburg, maar ook voor geheel Nederland (zie hoofdstuk 1).

In hoofdstuk $2 \mathrm{zijn}$ de in dit verband relevant gebleken factoren al aan de orde geweest (zie bijv. schema 2.1.). In dit hoofdstuk willen wij variabelen presenteren, die wij in de volgende verklarende hoofdstukken gaan gebruiken. In de eerste plaats worden de statistische kenmerken en de onderlinge samenhangen van de afhankelijke variabelen beschreven. Daarna laten wij de onafhankelijke variabelen de revue passeren. Wij beschrijven de constructie en inhoud van deze variabelen in par. 6.3 en de onderlinge samenhangen per variabelenrubriek in par. 6.4.

Hieraan voorafgaand eerst echter nog een enkel woord over de theoretische notie, die aan de nu volgende analyses ten grondglag ligt. In dit onderzoek gaat het -zoals al meerma-

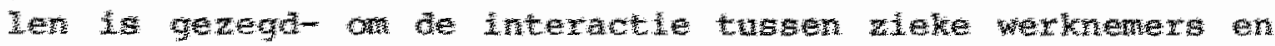

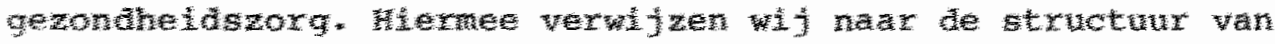

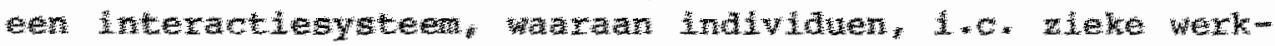

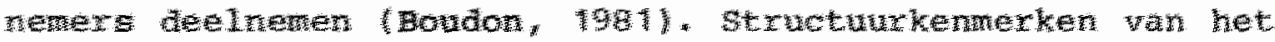

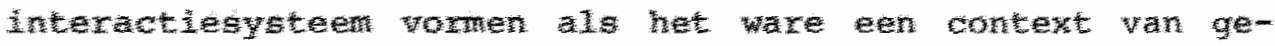

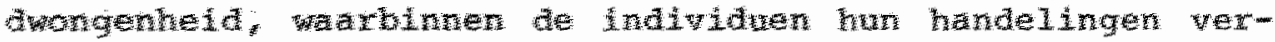

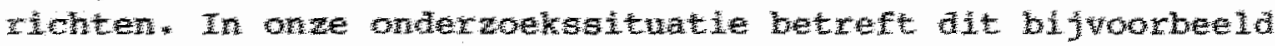

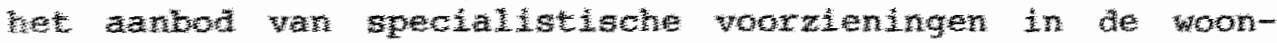
plates van de 1 ind

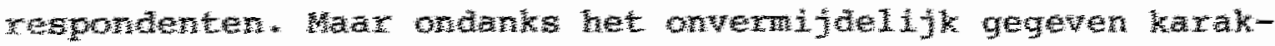

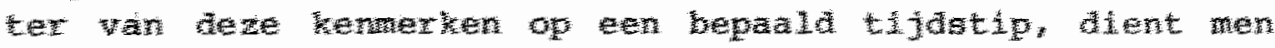

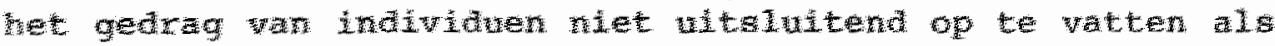

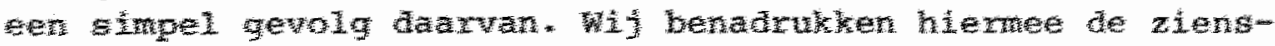

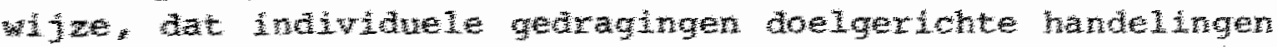


binnen een gegeven context zijn. Philipsen's (1969a, p. 1931) uitwerking van het verloop van een ziektegeval als besliskundig proces vormt een hier relevant voorbeeld van een dergelijke zienswijze.

Deze theoretische notie -ook wel aangeduid als het methodologisch individualisme (Boudon, 1981)-brengt ons ertoe, om in onze verklarende analyses zowel individuele gedragsvariabelen als contextuele structuurkenmerken tegelijkertijd op te nemen.

6.2. De te verklaren variabelen

Het beschikbare onderzoeksmateriaal maakt het in principe mogelijk, een groot aantal vragen betreffende de ziekteperioden van de respondenten te bestuderen. Onder meer ter wille van overzichtelijkheid is beperking evenwel geboden. In de hierna volgende drie hoofdstukken zullen wij daarom slechts een viertal kenmerken van de ziekteperiode nader analyseren (vgl. ook schema 2.1. in hoofdstuk 2):

- ten eerste zullen wij in hoofdstuk 7 het aantal doorverwijzingen naar specialistische zorg, het aantal verwijzingswachtdagen en het aantal stuurloze dagen nader gaan bestuderen;

- In hoofdstuk 8 zullen wij daarna meer specifiek ingaan op de totale ziekteduur.

In de genoemde hoofdstukken zal het de opzet zijn, om verschilien tussen de respondenten ten aanzien van deze kenmerken op statistische wijze te verklaren. Dat de respondenten op genoemde punten onderling aanzienlijk verschillen, blijkt overduidelijk uit tabel 6.1 .

Deze tabel heeft alleen betrekking op de 186 werkhervatters ult de steekproef. De 24 WAO/IP/VUT-instromers en de 3 ontslagenen laten wij hier verder buiten beschouwing; dit doen wij vanwege het feit, dat bij deze respondenten de ziekteproblematiek een vermenging kan hebben ondergaan met factoren betreffende het uittredingsproces zelf.

zoals gezegd, bestaan er ten aanzien van de genoemde kenmerken van de ziekteperioden forse verschillen tussen de wel hervattende patiënten. Zo blijkt het gemiddeld aantal door- 


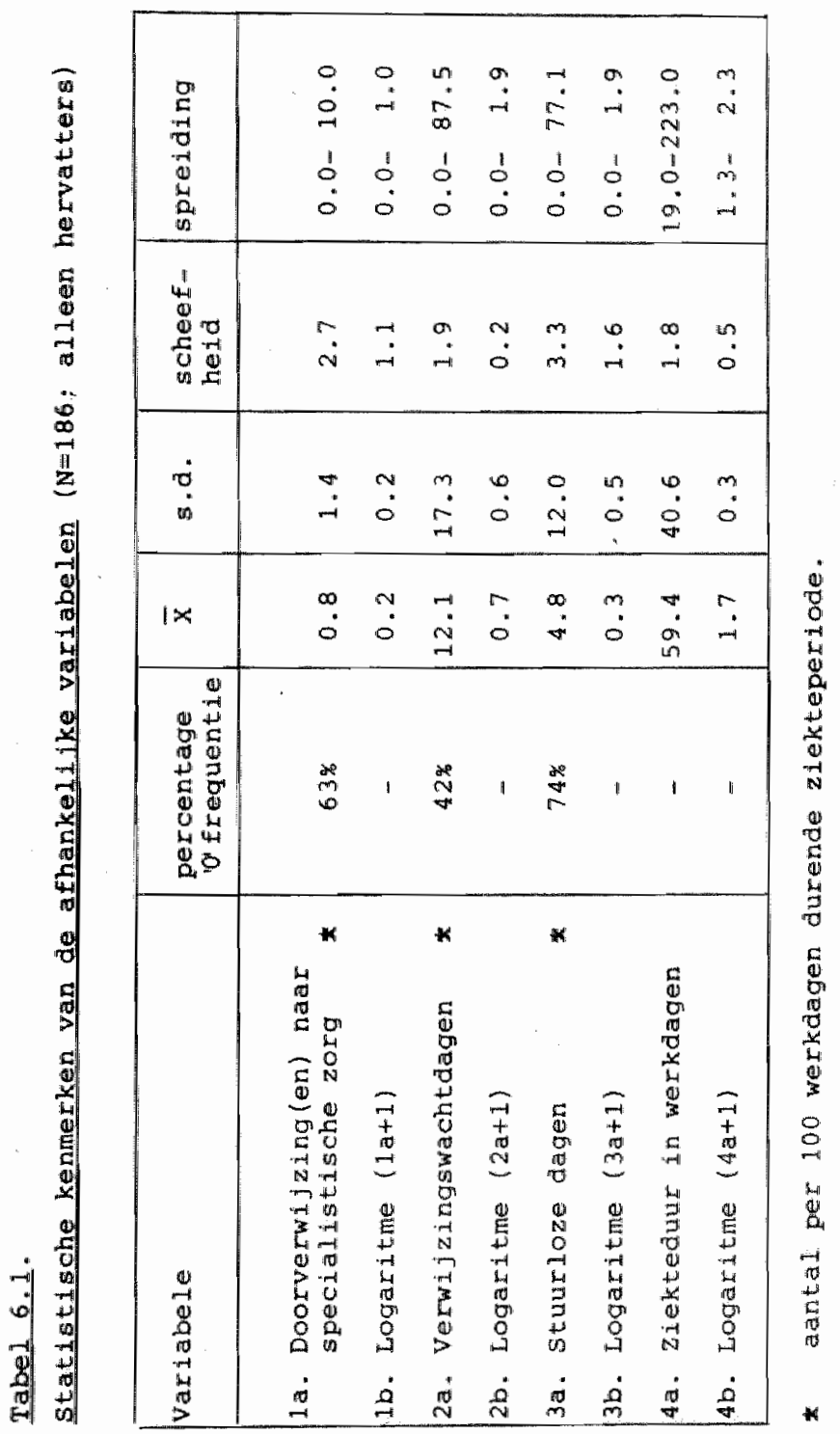


verwijzingen naar specialistische zorg* per 100 verzuimde werkdagen 1.4 te bedragen. Maar bij 63 van de hervatters kont zo'n doorverwijzing niet voor, terwijl er ook patiënten zijn, die 10 keer zijn doorverwezen. Voor wat het aantal verwijzingswachtdagen** en stuurloze dagen betreft, zijn de verschillen eveneens bijzonder groot. Per 100 verzuimde werkdagen makt men gemiddeld 12 verwijzingswachtdagen en bljna 5 stuurloze dagen mee, maar wachttijdperioden van bijna 90 dagen en stuurloze perioden van bijna 80 dagen komen ook voor. Voor wat de verdeling van deze variabelen betreft nog het volgende. De frequentieverdelingen van zowel het aantal verwijzingen als het aantal verwijzingswachtdagen en stuurloze dagen vertonen een continu dalende lijn (grafieken 6.1 en 6.2 in de bijlage). Dat wil zeggen, dat naarmate meer verwijzingen of verwijzingswachtdagen en stuurloze dagen in een ziekteperiode voorkomen, dit voor minder respondenten geldt.

De ziekteduur -tenslotte- loopt in de substeekproef van hervatters uiteen van minimaal 4 tot maximaal 45 werkweken. Gemiddeld zijn de werkhervatters bijna 12 weken ziek. Overigens hebben wij in ons onderzoek -toevalligerwijze- ook een respondent opgenomen, die minder dan 4 weken ziek was, namelijk 19 dagen.

Al met al blijken de gekozen 4 afhankelijke variabelen sterke verschillen tussen de patiënten op te leveren; hiermee is het stellen van de vraag naar de achtergronden van deze verschillen gerechtvaardigd.*** In de navolgende hoofdstukken gaat het ex dan ook om, te achterhalen welke van de nog te beschrijven onafhankelijke variabelen samengaan met veel verwijzingscontacten, verwijzingswachtdagen, stuurloze dagen en lange ziekteduren.

* dit is inclusief doorverwijzing naar ziekenhuisopname;

* het gaat hier on alle wachtdagen minus de dagen voor le consult en minus de stuurloze dagen.

*** Deze verschillen zijn zelfs van dien aard, dat op deze variabelen logaritmische transformaties zijn toegepast; hiermee wordt het effect van extreem hoge maar weinig frequente waarden verminderd. 
De keuze voor deze 4 afhankelijke variabelen is hiermee met een technischtheoretisch criterium beargumenteerd: er zijn verschillen, waar hangen die mee samen? Er zijn evenwel meer kenmerken van de ziekteperiode die dergelijke grote verschillen tussen de patiënten te zien geven. Aan de keuze voor juist deze vier afhankelijke variabelen hebben dan ook nog andere -meer beleidsmatige- overwegingen ten grondslag gelegen.

Dat de ziekteduur onderwerp van nadere analyse wordt, heeft te maken met de oorspronkelijke doelstelling van het onderzoek; dat onderzoek was immers het gevolg van een initiatief van de provinciale overheid in Limburg, die meer te weten wilde komen over de lange ziekteduren in die provincie. Vanwege diezelfde achtergrond wordt in het navolgende ook dieper ingegaan op de oorzaken van de wachttijden.

De wachttijden zijn in twee categorieën opgedeeld, omdat op die manier enigermate recht wordt gedaan aan het gedifferentieerd karakter van de diverse wachttijdperioden.

Voor wat de wachttija tijdens verwijzing betreft, kan men de vertraging in de behandeling op conto van de curatieve gezondheldszorg schrijven. De stuurloze periode daarentegen kan enerzijds het gevolg zijn van een gebrekkige communicatie tussen de verzekeringsgeneeskundige en de behandelingssector, maar anderzijds ook nadrukkelijk de consequentie van een geringere activiteit van de patiënt. Een actieve patiënt zal zich immers aan het begin van een stuurloze periode wenden tot zijn $H A$, VG of $B A$. Het aldus gemakkte onderscheid tussen verwijzingswachttijden en de stuurloze perioden correspondeert ongeveer met de in het Angelsaksisch taalgebied gebruikelijke tweedeling in "doctor's and patient's delay" (bijv. Blackwe11, 1963).

De gekozen indicator voor medische consumptie -tenslotteis gebaseerd op het idee, dat studie van verwijzingswachtdagen vooral van betekenis is voox de patiënten, die doorverwezen worden naar specialistische zorg in tweede of derde echelon. Voorafgaand aan de vraag naar de achtergronden van verwijzingswachtdagen, dient men dus eerst bestudeerd te hebben, welke patiënten naar specialist of ziekenhuls doorverwezen worden.

Bij deze doorverwezen patiënten kan men vervolgens gaan bestuderen, welke patiënten lange verwijzingswachttijden meemaken. 
Ter afronding van deze paragraaf willen wij nog laten zien, hoe de door ons gekozen afhankelijke variabelen onderling gerelateerd zijn. Blijkens tabel 6.2. is er sprake van 3 significante onderlinge samenhangen.

Tabe1 6.2 .

Onderlinge samenhangen van de te verklaren varlabelen; nulde-oxde correlatie-coëfficiënten, allen significant bij $\mathrm{p} \leqslant 0.05(\mathrm{~N}=186$, alleen hervatters $)$.

\begin{tabular}{|l|cccc|}
\hline 1. & aantal verwijzingen & $(1)$ & & \\
2. & - & $(2)$ & & \\
3. aantal verwijzingswachtdagen & $44 * * *$ & - & (3) & \\
4. aantal stuurloze dagen & - & $-13 *$ & - & (4) \\
\hline
\end{tabular}

$\begin{array}{ll}* * * & 0.00<\mathrm{p} \leqslant 0.001 \\ * \quad & 0.01<\mathrm{p} \leq 0.05\end{array}$

Ten eerste suggereert tabel 6.2. dat het aantal verwijzingswachtdagen samenhangt met het aantal verwijzingen. Dit is een "logische" samenhang, immers zonder verwijzingen kunnen zich ook geen verwijzingswachtdagen voordoen. Berekent men deze coëfficiënt evenwel uitsluitend voor de patiënten, die tenminste één keer tijdens hun ziekteperiode naar specialistische zorg verwezen zijn, dan valt het verband volledig weg $(r=-0.03$, N.S. $)$. Met andere woorden: het aantal verwijzingswachtdagen hangt niet samen met het aantal verwijzingen, maar uitsluitend met het feit, dat men verwezen wordt. Gelet op de uitkomsten van hoofdstuk 4 is dit ook logisch, omdat verwijzingswachtagen zich vooral bij sommige specialismen voordoen. Bij wijze van voorbeeld: een verwijzing naar een rheumatoloog duurt langer dan drie verwijzingen naar een internist (zie tabel 4.19).

Ten tweede blijkt het aantal verwijzingswachtdagen licht negatief samen te hangen met het aantal stuurloze dagen. Respondenten maken kennelijk hetzij stuurloze hetzij verwijzingswachtdagen mee; deze tweedeling correspondeert mogelijkerwijze met twee typen van behandelingslijnen. In de derde plaats loopt het aantal verwijzingswachtdagen tot op zekere hoogte in de pas met de ziekteduur. Dit illustreert dat de problematiek van lange ziekteduren voor een gedeelte samenvalt met het wachttijdenvraagstuk, zoals wij 
ook al in hoofdstuk 4 zagen. De stuurloze dagen blijken niet te correleren met de ziekteduur. Dit betekent, dat respondenten, die relatief veel stuurloze dagen meemaken, niet noodzakelijk ook relatief lang of juist kort ziek zijn. Overigens, kan deze correlatie per diagnosecategorie anders uitvallen.

\subsection{De verklarende variabelen}

Eerder hebben wij al gesteld, dat dit onderzoek zich beperkt tot het domein der medische sociologie en gezondheidszorgeconomie. Biologische aspecten van de ziekte blijven buiten beschouwing, terwijl ook een psychologische vxaag, zoals die naar "Persoonlijkheid en medische consumptie" (v.d. Ploeg, 1980) buiten het bereik van deze studie valt.

Maar ook binnen het terrein van de medische sociologie hebben wij ons bij de selectie van variabelen beperkingen moeten opleggen. Men moet ex zich in de fase van de dataverzameling immers voor hoeden, de respondenten te overbelasten. Indien de door de onderzoeker verlangde medewerking niet in evenwicht is met wat de respondenten als redelijk voorkomt, dreigt een verhoogde non-response of een onzorgvuldige beantwoording van de vragen. Verder is het zo, dat het aantal te hanteren variabelen begrensd wordt door de omvang van de steekproef (bijv. Philipsen, 1969a). Vandaar, dat in elk onderzoek een zwaartepunt bij de concretisering van de vraagstelling moet worden gekozen. In dit onderzoek hebben wij gekozen voor de patiënt-gezondheidszorg-interactie als centrale determinant van medische consumptie, wachttijden en ziekteduren. Wij hebben deze keuze gemaakt, omdat op dit veld van onderzoek nog relatief weinig bekend is.

Dit heeft wel tot gevolg, dat onder meer de volgende door anderen bestudeerde determinanten van medische consumptie en ziekte in het nu komende niet zijn opgenomen:

- de zgn. belastende levensgebeurtenissen ("stressfull life events"), zoals een ontslag of het overlijden van de partner (Wiersma, 1979, van Eijk, 1979, Millard waltz, 1981);

- riskante leefgewoonten, bijvoorbeeld roken (Philipsen, 1977 ) en probleemarinken (Knibbe, 1982): 
- het kunnen ongaan met risicofactoren, ofwel "coping behavior" (bijv. Karmaus, 1983);

- het sociale netwerk van de patiënt (Mootz, 1981; Badura, 1981; Mckinlay, 1981; Twaddle, 1981);

- de kennis van de patiënt omtrent ziekte en gezondheid (Tagliacozze and Ima, 1970; Cassee, 1973) en

- algemene gezondheidsopvattingen (Cassee, 1973; Adriaanse e.a., 1981).

De wel in dit onderzoek opgenomen verklarende variabelen zijn inhoudelijk in een vijftal categorieën onder te brengen.

Vier van de variabelencategorieën komen nauw overeen met de factoren, die in het literatuurhoofdstuk 2 als bepalend voor onze vraagstellingen naar voren zijn gekomen (zie bijv. schema 2.1.). Achtereenvolgens zijn dit: kenmerken van de aandoening(en) van de respondenten, persoonskenmerken, kenmerken van het werk van de respondenten en indicatoren van het aanbod van gezondheidszorgvoorzieningen. Een andere belangrijke factor in verband met onze probleemstelling betrof de samenwerking tussen de behandelende en verzekerings-, c.q. bedrijfsgeneeskundige sector. Hierover hebben wij helaas geen gegevens beschikbaar. Ons materiaal is immers uitsluitend gebaseerd op informatie van de zlieke respondenten; deze hebben vanzelfsprekend geen zicht op wat zich buiten hun directe aanwezigheid afspeelt. Om deze reden hebben wij ook geen informatie over de (taak-)opvattingen van artsen. Daarom beperkt ons onderzoek zich tot de patiënt-gezondheidszorg-interactie, voorzover deze door patiënten waargenomen kan worden. Om de invloeden daarvan te meten hebben wij nog een vijfde variabelenblok gemaakt; dit bestaat uit kenmerken van de behandeling.

Een beknopte beschrijving van elke variabele per categorie vormt de inhoud van de rest van deze paragraaf. Voor een overzicht van enkele statistische kenmerken van de variabelen zij verwezen naar tabel 6.3. in de bijlage van dit hoofdstuk. In de bijlage is voorts beschreven, via welke statistische procedures de onafhankelijke variabelen zijn geconstrueerd.

Tenslotte nog dit: wij spreken hier geen verwachtingen uit omtrent het effect van iedere onafhankelijke variabele op medische consumptie, wachttijden en lange ziekteduren. Dit onderzoek heeft immers een explorerend karakter, omdat veel van de hier te presenteren onafhankelijke variabelen -al- 
thans voorzover ons bekend- nog niet bij een steekproef als de onze zijn onderzocht. Voor wat het voorafgaande onderzoek op dit gebied wel heeft opgeleverd, zij verwezen naar hoofdstuk 2 .

Persoonskenmerken:

In deze variabelencategorie zijn achtereenvolgens opgenomen:

- de leeftijd van de respondenten gecodeerd in 5 klassen,

- het geslacht,

- de nationaliteit; hierbij zijn twee categorieën gehanteerd, te weten de Nederlandse en niet-Nederlandse nationaliteit,

- de verzekeringswijze tegen loonderving bij ziekte; hiervoor zijn de GAK-verzekerden onderscheiden van de andere respondenten, zijnde hoofdzakelijk ambtenaren in de zin van de Pensioenwet en personeelsleden van gezondheidszorginstellingen,

- de verzekeringswijze tegen ziektekosten; hierbij is wederom een dichotomie gehanteerd, en wel met betrekking tot de vraag of men al dan niet via het ziekenfonds verplicht verzekerd is, en

- het (hoogste) opleidingsnivo van de respondenten; deze variabele is gecodeerd in 9 klassen, lopend van lager onderwijs tot een universitaire opleiding.

Alle variabelen $z i j n$ geconstrueerd op basis van informatie, die tijdens het eerste interview is verzameld.

Kenmerken van de aandoening

In dit blok is een viertal variabelen met betrekking tot de ziekte of aandoening opgenomen.

In de eerste plaats is aan de respondenten een verkorte versie van de bekende VoEG-1ijst (Dirken, 1967) voorgelegd. Deze klachtenlijst bedoelt een indicatie te geven van de ervaren gezondheidstoestand, maar een score erop vormt -naar het oordeel van v.d. Zee (1982) - tevens een ulting van de klaaggeneigaheid van de respondenten (vgl. aok Mechanic, 1979). volgens visser (1983) is de VOEG niet uitsluitend een vragenlijst ter meting van de beleving van de somatische gezondheid; zijns inziens is het eveneens een indicator van het algemene onwelbevinden van mensen, die ook het gevolg is van psychische en sociale klachten. Daarom dient men naast de VOEG ook meer objectieve indicatoren van de gezondheidstoestand in de analyse te betrekken. 
Ten eerste hebben wij hiertoe een variabele "ziekteverleden" geconstrueerd. Deze variabele geeft aan, in hoeverre er sprake is van een al langer durende aandoening. Deze variabele kwam tot stand door middel van een sommatie van de scores op vier vragen:

- heeft de patiênt voor dezelfde aandoening zich reeds eerdex ziek gemeld, dan wel een specialist bezocht?

- had de patiënt de klachten al langer, of zijn ze plotseling ontstaan?

- was de patiënt op de datum van de ziektemelding al onder medische behandeling?

Hoe hoger de score op deze variabele, des te meer is ex sprake van een ziekteverleden. Naast dit kenmerk betreffende het ziekteverleden is verder nog vastgesteld, of de patiënt ook nog een of meer nevendiagnoses had.

Tenslotte zijn de oorspronkelijke 16 hoofddiagnosegroepen samengevoegd tot twee hoofdcategorieèn, te weten:

* de aandoenlngen, die wijzen op bewegingsbeperkingen; hieronder vallen de ziekten van zenuwstelsel en zintuigen, de ziekten der bewegingsorganen en de ongevallen; versus

* de aandoeningen, die de algemene lichamelijke conditie aantasten; hieronder vallen alle andere diagnosegroepen. Deze indeling is ontleend aan en beargumenteerd door MerensRiedstra (1981).

Alle variabelen uit dit blok hebben betrekking op materiaal uit het eerste interview.

Kenmerken van de behandeling

Tot dit varlabelenblok behoort ten eerste het oordeel van de patiënten over (de duidelijkheid van) de behandeling tot op het moment van het eerste interview. In deze variabele zijn de antwoorden op arie vragen verwerkt:

- heeft de arts voldoende informatie verstrekt over de aard van de aandoening?

- is de aard van de aandoening aan de patiënt voldoende duidelijk?

- hoe tevreden is de patiënt over de behandeling tot dusverre?

Hoe hoger de score op deze variabele, des te duidelijker en bevredigender is de behandeling voor de patiënt geweest.

In de tweede plaats is aan de patiënten een lijst van uitspraken over de werkwijze van hun huisarts voorgelegd. Deze 
lijst vormt een selectie uit de desbetreffende vragenbatterij van Cassee (1973); de lijst bevat o.a. uitspraken over het communicatief en instrumenteel handelen van de huisarts. Naarmate de score op deze variabele hoger is, heeft de respondent er blijk van gegeven, meer tevreden te zijn over het functioneren van zijn/haar huisarts. Deze variabele, alsmede de variabele over de duidelijkheid van de behandeling, zijn gebaseerd op basis van materiaal uit het eerste interview.

De vijf resterende variabelen uit deze categorie betreffen kengetallen van de behandeling tijdens de ziekte. Deze variabelen hebben derhalve betrekking op informatie betreffende de gehele ziekteperiode. Het gaat hierbij resp. om:

- het aantal keren, dat men in het ziekenhuis is opgenomen,

- het aantal keren, dat men met de VG contact heeft gehad, - het aantal keren, dat men contact heeft gehad met een specialist,

- het aantal keren, dat men op eigen initiatief contact heeft gehad met de huisarts, en

- het aantal keren, dat men bij de huisarts is terugbesteld.

Bij de twee laatste variabelen wordt afgezien van de vraag, of de patiënt naar de huisarts is gegaan, dan wel door hem of haar thuis is bezocht.

Voor al deze vijf variabelen geldt, dat ze gestandaardiseerd zijn naar de frequentie van voorkomen tijdens een 100 werkdagen durende ziekteperiode; ook deze vijf variabelen zijn logaritmisch getransformeerd.

Werk van de patiënten

Tot deze categorie van variabelen -bekend uit ziektevexzuimonderzoek (bijv. Miersma, 1979)- wordt hier een zestal gegevens gerekend. Ten eerste gaat het hier om de fysieke arbeidsomstandigheden in het werk van de patiënten, met andere woorden de werkinconveniënten. Deze zijn gemeten volgens de subjectieve methode, dus volgens de waarneming van de patiënten zelf; zij konden aangeven, welke van de opgesomde arbeidsomstandigheden in hun werk hinder opleveren. Onder fysieke omstandigheden zijn zaken begrepen als: trilling, koude/warmte, vuil, tocht, stof, lawaii, lichamelijk zwaar werk en stank. Voor deze variabele impliceert een hoge score, dat de patiënt in kwestie veel hinder van arbeidsomstan- 
digheden ondervindt.

Daarnaast hebben wij een algemene arbeidssatisfactie-schaal geconstrueerd; die geeft met een hoge score aan, dat de respondent in kwestie gunstig denkt over vier aspecten van zijn werk, te weten: de inhoud van het werk, financlële aspecten ervan, het arbeldstempo en de wardering door chef of baas. De oordelen over deze 4 werkkenmerken vormen de items, waarult deze schal is opgebouwd.

De belde zojuist besproken variabelen hebben rechtstreeks betrekking op het werk van de respondenten op het moment, dat zij ziek werden. De vier nu volgende variabelen zijn meer afgeleiden daarvan. Ten eerste is een variabele met betrekking tot het arbeidsverleden van de patiënten ontworpen. In deze variabele 1 s opgenomen, hoe vaak de respondenten ontslagen en/of werkloos zijn geweest, alsmede hoeveel functies en werkgevers men heeft gehad voor de betreffende werkkring ten tijde van het onderzoek. Een hoge score duidt op een onstabiel arbeldsverleden, met veel wisselingen en/of werkloosheldsperioden.

Dan is in het onderzoek nagegaar, hoe vaak de patiënten tijdens hun ziekteperiode thuis door collega's en/of andere functionarissen uit hun werkkring zijn bezocht. Met deze variabele proberen wij te indiceren, hoeveel contact en voeling de patiënten tijdens hun ziekte met hun werkkring hebben behouden. Gemiddeld 1 keer per 100 kalenderdagen hebben de respondenten bezoek van collega's e.d. ontvangen. Hierbij zij aangetekend, dat deze variabele extreem scheef verdeeld is, hetgeen erop wijst, dat betrekkelijk veel mensen helemaal geen bezoek hebben ontvangen en een geringer aantal juist heel valik bezocht is door collega's e.d.

Verder hebben wij in deze rubriek de vraag opgenomen, of de werkhervatting met een of meer werkaanpassingen heeft plaatsgevonden. Naarmate op deze variabele hoger gescoord is, is ex sprake van meer werkaanpassingen geweest.

Tenslotte hebben wij uit het organisatie-onderzoek van N1jhuis en soeters (1982) een variabele met betrekking tot de werkzekerheid in het bedrijf of de instelling van de zieke werknemers overgenomen. Een hoge score op deze variabele impliceert een grotere mate van werkzekerheid, tot uiting komend in het minder vaak voorkomen van ontslagen, werktijaverkorting, reorganisaties e.d. (zie verder hiervoor Nijhuis en soeters, 1982).

De variabelen "werkinconveniënten", "arbeldsatisfactie" en 
"arbeidsverleden" zijn gebaseerd op gegevens uit het eerste interview. De variabele "bezoek" is geconstrueerd op grond van informatie uit zowel het eerste als het laatste interview. De variabele "werkaanpassing" heeft alleen betrekking op data uit het laatste interview. De variabele "werkzekerheid" is -zoals gezegd- afkomstig uit het organisatie-onderzoek van Nijhuis en Soeters (1982).

\section{Gezondheidszorgaanbod}

In deze laatste rubriek hebben wij een arietal indicatoren met betrekking tot het aanbod van gezondheidszorgvoorzieningen in de woonplaats van de patiënten ondergebracht. Alle drie de indicatoren hebben betrekking op een gemeentelijk of regional aggregatie-nivo en vormen derhalve -vanuit het standpunt van de patiënt bekeken- contextuele structuurvariabelen (conform bijv. Van der Zee, 1982; en v.d. ven \& v. vilet, 1982). Omdat wij hier variabelen van twee verschillende analyse-nivo's met elkaar in verband brengen, moet men niet al te veel hoop hebben op een succesvolle afloop van dit deel van de analyses (vgl. ook Mechanic, 1979). Wanneer wij evenwel in staat zijn om dergelijke verbanden te vinden, doen wij meer recht an de complexiteit van de sociale werkelijkheid in het algemeen (Mooy, 1980; Boudon, 1981) en die van de behandeling van patiënten in het bijzonder.

Ten eerste is uit het Iimburgse Infomatiesysteem van de ziekenfondsen per gemeente de gemiddelde omvang van de huisartsen-praktijken gedestilleerd en via de gemeentecode toegekend aan elke respondent. In feite betreft het hier het aantal inwoners per gemeente per hulsarts. In totaal kent deze variabele 40 warden, zijnde de 40 gemeenten in zuldelijk Limburg, war de respondenten woonachtig waren. De gegevens hebben betrekking op 1981 .

Vervolgens is bepaald, hoe groot de afstand in vogelvlucht is tussen elke Limburgse gemeente en het meest nabij gelegen Limburgse ziekenhuis (gemeten in tienden millimeters op de landkaart, schaal 1:280.000). Van elk meest nabij gelegen ziekenhuis is bovendien vastgelegd, hoeveel specialismen exin vertegenwoordigd zijn. Dit gegeven is afkomstig uit het Geneeskundig adresboek van 1981-1982. Beide kenmerken zijn via de gemeentecode toegekend aan de respondenten. In onze steekproef kunnen deze beide variabelen 7 waarden annemen, corresponderend met het aantal ziekenhuizen, dat gevestiga 
is in het Herstructureringsgebied $\mathrm{z}$-Limburg. Voor wat betreft het aantal specialismen in het meest nabijgelegen ziekenhuis betreft, kan nog vermeld worden, dat er in de betrokken $z$-Limburgse zlekenhuizen tenminste 95 en maximaal 24 specialismen vertegenwoordigd zijn.

\subsection{De onderlinge samenhangen der variabelen}

De in de hoofdstukken 7 en 8 te presenteren verklarende analyses zullen uitgevoerd worden met in total 25 onafhankelijke variabelen, te verdelen over 5 variabelenrubrieken. In tabel 6.4 in de bijlage zijn alle significante produktmomentcorrelaties tussen deze 25 onafhankelijke variabelen weergegeven. Met uitzondering van de correlatiecoëfficiënt. tussen de ziektekosten- en loondervingsverzekering ( $r=.61)$, bereiken de correlaties zelden hogere warden dan .30 en vrijwel noolt hoger dan .40 . Dit impliceert, dat het aantal variabelen niet meer samengevoegd en derhalve gereduceerd kan worden. Dat zou namelijk ten koste gaan van de betrouwbaarheid en daarmee van de verklaringskracht der variabelen (Maxwe11, 1977).

Dat wij de variabelen met betrekking tot de ziektekosten- en loondervingsverzekering niet samenvoegen, berust op de volgende overweging. Voor één afhankelijke variabele, te weten het aantal doorverwijzingen, is vooral de wijze van ziektekostenverzekering van belang; voor de analyses op de ziekteduur lijkt daarentegen de variabele aangaande de loondervingsxegeling van betekenis.

In het resterende gedeelte van deze paragraaf zullen wij de onderlinge structuur der onafhankelijke variabelen per rubriek bestuderen. Dit gebeurt door per rubriek de significante relaties te bespreken.

Persoonskenmerken:

Van de mogelijke 10 verbanden tussen de vijf variabelen uit deze rubriek resteren ex 7 , die bij $p \leqslant 0.05$ significant zijn. Tabel 6.5. brengt dit in beeld. 
Tabel 6.5 .

onderlinge samenhangen der persoonskemmerken; nulde-orde correlatie-coëfficiënten, allen significant bij $p \leqslant 0.05$ $(\mathrm{N}=186)$

\begin{tabular}{|c|c|c|c|c|c|}
\hline $\begin{array}{l}\text { 1. leeftijd } \\
\text { 2. geslacht } \\
\text { 3. opleiding } \\
\text { 4. ziektekosten } \\
\text { 5. loonderving }\end{array}$ & $\begin{array}{l}(1) \\
- \\
-17 * \\
- \\
28 * * * \\
19 *\end{array}$ & $\begin{array}{l}(2) \\
- \\
- \\
-19 * * \\
-\end{array}$ & $\begin{array}{c}(3) \\
- \\
22^{*} \\
17 *\end{array}$ & $\begin{array}{c}(4) \\
- \\
61 * * *\end{array}$ & $\begin{array}{c}\text { (5) } \\
-\end{array}$ \\
\hline
\end{tabular}

$$
\begin{array}{ll}
* * * & 0.00<p \leqslant 0.001 \\
* * \quad & 0.001<p \leqslant 0.01 \\
* \quad & 0.01<p \leqslant 0.05
\end{array}
$$

De meeste verbanden concentreren zich rondom de ziekenkosten- en loondervingsvariabelen. Beide variabelen zijn ook sterk gerelateerd:

De GAK-verzekerden zijn namelijk doorgaans krachtens de ziekenfondswet tegen ziektekosten verzekerd. Hierbij speelt in de eerste plaats het feit, dat de ambtenaren in de steekproef per definitie niet ziekenfonds-verzekerd kunnen zijn. Verder wijst dit verband er vermoedelijk op, dat de GAK-verzekerden gemiddeld lagere inkomens verwerven dan de nietGAK-verzekexden. In dit verband is het niet onbelangrijk nogmaals te vermelden, dat de GAK-verzekerden voor een belangrijk gedeelte werkzaam zijn bij industriële bedrijven, terwijl de niet-GAK-verzekerden overwegend bestaan uit werknemers van nutsbedrijven en van gezondheidszorginsteliingen.

In overeensteming hiermee zijn zowel de hoger opgeleide als de oudere respondenten vakex particulier tegen zlektekosten verzekerd. Hetzelfde geldt voor de mannelijke respondenten. De relatief hogere posities en inkomens van deze drie respondentcategorieën vormen enerzijds hiervan de achtergrond. Anderzijds staan deze uitkomsten in verband met twee andere relaties uit tabel $6.5 .:$ hoger opgeleide en oudere respondenten zijn vaker niet bij het GAK verzekerd. Deze laatste twee verbanden stemmen op hun beurt weer overeen met het bekende gegeven, dat ambtenaren relatief hoger opgeleid en ouder zijn dan werknemers in de particuliere sector (V.d. Bosch \& Petersen, 1980). 
Tenslotte blijkt uit tabel 6.5 . dat de mannelijke respondenten gemiddeld ouder zijn dan de vrouwelijke. Dit kont overeen met de werkelijke sltuatie aangaande de beroepsparticipatie van vrouwen.

Kenmexken van de aandoening:

Deze rubriek bevat 4 variabelen, die 3 onderlinge significante relaties opleveren:

Tabel 6.6 .

Onderlinge samenhangen van de kenmerken van de a andoening; nulde-orde correlatie-coëfficiënten, allen significant bij $\mathrm{p} \leqslant 0.05 \quad(\mathrm{~N}=186)$.

\begin{tabular}{|c|c|c|c|c|}
\hline $\begin{array}{l}\text { 1. zlektever leden } \\
\text { 2. vozG } \\
\text { 3. nevendiagnose } \\
\text { 4. diagnose }\end{array}$ & $\begin{array}{c}11 \\
- \\
21 \\
- \\
-\end{array}$ & $\begin{array}{l}(2) \\
- \\
15 * \\
34^{* * *}\end{array}$ & $\begin{array}{c}(3) \\
- \\
-\end{array}$ & $\begin{array}{c}\text { (4) } \\
-\end{array}$ \\
\hline
\end{tabular}

$$
\begin{array}{ll}
* * * & 0.00<\mathrm{P} \leqslant 0.001 \\
* * & 0.001<\mathrm{P} \leqslant 0.01 \\
* & 0.01<\mathrm{P} \leqslant 0.05
\end{array}
$$

In deze rubriek vormt de VOEG-score kennelijk de centrale variabele. Immers, deze houdt verband met alle drie de andere variabelen, als yolgt: het aantal klachten, aangegeven op de VOEG-lijst, is groter, wanneer men een of meer nevendiagnoses heeft, wanneex de aandoening wijst op een verslechterende algemene lichamelijke conditie en wanneer er sprake is van een al langer durende aandoening.

Kenmerken van de behandeling

Van de 21 mogelijke relaties resteren ex in deze rubriek 9, die significant zijn. 
Tabel 6.7.

Onderlinge samenhangen van de kenmerken van de behandeling; nulde-orde correlatie-coëfficiënten, allen significant bij $p \leqslant 0.05 \quad(N=186)$

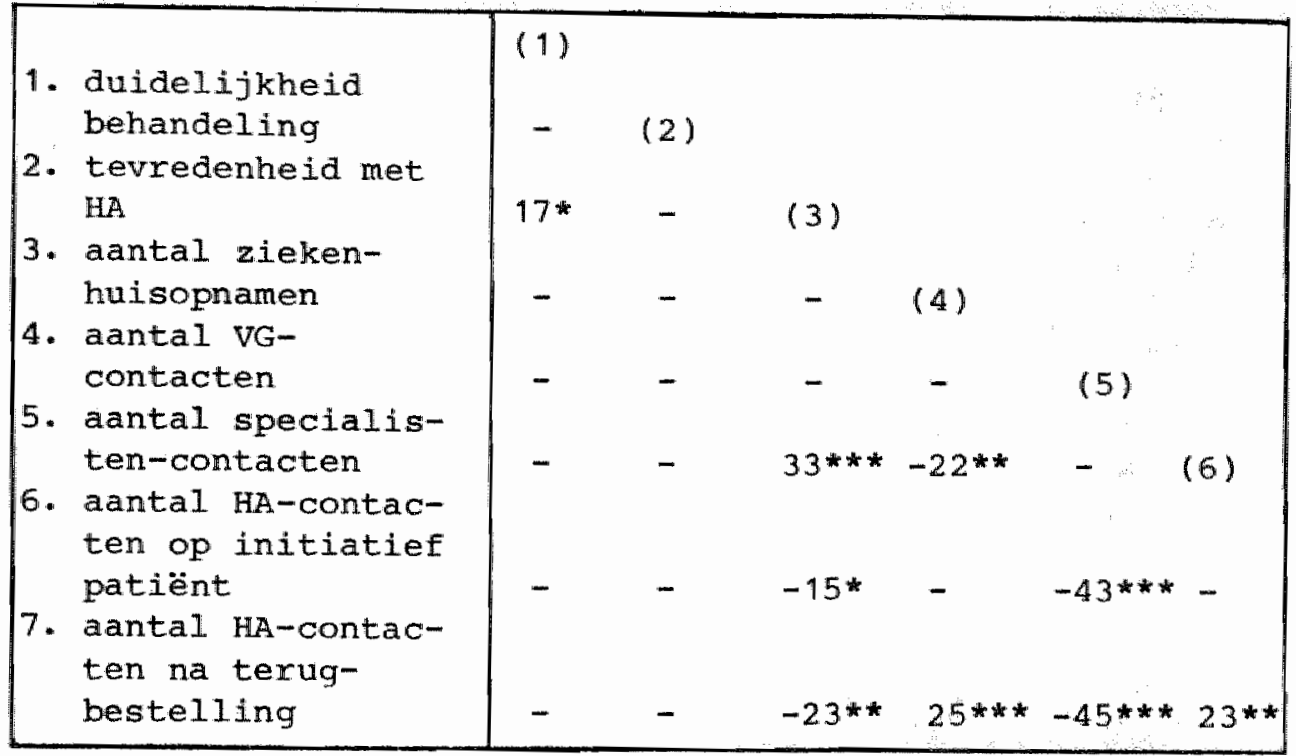

$\begin{array}{ll}* * * & 0.00<p \leqslant 0.001 \\ * * & 0.001<p \leqslant 0.01 \\ * & 0.01<p \leqslant 0.05\end{array}$

Deze tabel kan men als volgt verwoorden:

- naarmate men vaker één of meer specialisten consulteert. gaat men minder vaak uit eigen beweging naar de huisarts en wordt men daar ook minder vaak terugbesteld. Heel duidelijk komt hier naar voren, dat langdurig zieken doorgaans overwegend hetzij in de eerste, hetzij in de tweede lijn behandeld worden. Dit wordt nog versterkt door het resultaat, dat respondenten, die vaker uit eigen beweging naar de huisarts gaan, daar ook vaker terugbesteld worden.

- verder is ook het aantal keren, dat de patiënten contact met de VG hebben kleiner, naarmate men meer contacten met specialisten heeft en minder vaak door de huisarts terugbesteld wordt. Kennelijk achten VG-en contact met hun zieke verzekerden minder zinvol en urgent, wanneer deze in de tweede lijn behandeld worden. Vermoedelijk speelt het 
feit, dat meer objectieve aandoeningen waker naar het tweede echelon worder doorverwezen, een rol bij deze beslissing.

- In overeensteming met wat men op grond van gezond verstand kan begrijpen, blijkt men vaker met specialisten en mindex valk met huisartsen contact te hebben, wanneer men terminste eenmaal in het ziekenhuis is opgenomen.

- tenslotte mag het geen verwondexing wekken, dat men meer tevreden over zijn of haar huisarts is, naarmate de aard van de behandeling in de eerste weken (door vermoedelijk de huisarts) beter is verduidelijkt.

Kenimerken van het werk

In deze rubriek zijn 6 varlabelen betreffende het werk van de patiënten opgenomen, die in principe 15 onderlinge relaties vormen. Van deze 15 relaties zijn er evenwel slechts 2 significant bij $p \leqslant 0.05$ :

Tabel 6.8 .

Onderlinge samenhangen van de kenmerken van het werk; nuldeorde correlatie-coëfficiënten, allen significant bij p $\leqslant 0.05$ $(\mathrm{N}=186)$.

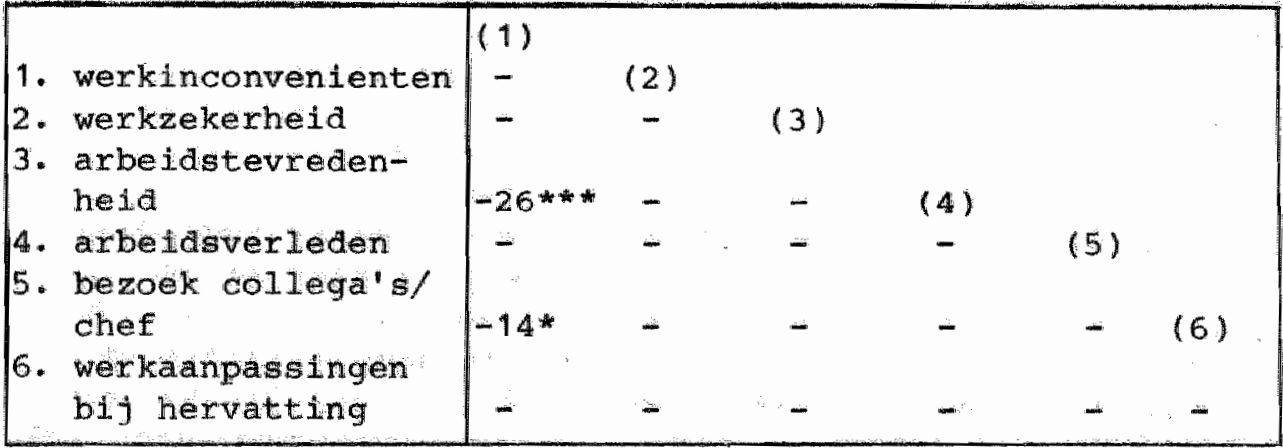

$$
\begin{array}{ll}
* * \quad & 0.00<\mathrm{p} \leqslant 0.001 \\
* \quad & 0.01<\mathrm{p} \leqslant 0.05
\end{array}
$$

Naarmate men meer inconveniënten in zijn werk ondervindt, heeft men een geringere arbeidssatisfactie. Dit verband komt overeen met andere onderzoeksresultaten in dit opzicht. Verder blijken de patienten, die meer werkinconveniënten ervaren, minder valk tijdens hun ziekteperiode door chef en/of 
collega's thuis bezocht te worden.

Kenmerken van het gezondheidszorgaanbod

Van de drie mogelijke relaties in deze rubriek is er $1 \mathrm{sig-}$ nificant. Naarmate de afstand tussen de woonplaats van de patiënt en het dichtstbijzijnde ziekenhuis groter is, is het aantal in dat ziekenhuis vertegenwoordigde specialismen kleiner $(r=-.35 ; p=0.001)$. Dit verband vormt een effect van de urbanisatiegraad, immers de afstand tot het ziekenhuis en de urbanisatiegraad correleren .87 . Het gevonden verband geeft dus alleen maar weer, dat de klimieken in de grotere gemeenten meer specialismen in huis hebben; dit wekt geen verwondering.

Hiermee is de bespreking van de onderlinge structuur der onafhankelijke variabelen voltooid.

\subsection{Samenvatting}

In dit hoofdstuk is ten eerste een beschrijving gegeven van de in hoofdstuk 7 en 8 nader te bestuderen afhankelijke variabelen. Het gaat hierbij, om het aantal doorverwijzingen richting specialistische zorg in tweede en derde echelon. het aantal verwijzingswachtdagen, het aantal stuurloze dagen en -tenslotte- de volledige ziekteduur. Ten tweede is een overzicht gegeven van de 25 onafhankelijke variabelen, die ondergebracht zijn in 5 variabelenrubrieken. In de derde plaats is de onderlinge structuur van de onafhankelijke variabelen per rubriek in beeld gebracht. 
HOOFDSTUK 7.

DE VERKLARING VAN DE VERSCHILLEN IN HET VERWIJSCIJFER, VERWIJZIVGSWACHTDAGEN EN STUURLOZE PERIODEN.

\subsection{Inleiding}

In dit hoofdstuk zullen wij een drietal verklarende analyses verrichten; deze hebben betrekking op:

a. het aantal verwijzingen naar specialistische zorg, in het tweede of derde echelon;

b. het aantal wachtdagen, dat tijdens verwijzingsperioden optreedt, en

c. het antal stuurloze dagen, i.e. de dagen, waarop geen sprake is van continuering van de behandeling.

Wij zullen nagaan, in hoeverre de 25 onafhankelijke variabelen bijdragen aan de statistische verklaring van de patiëntgewijze verschillen ten aanzien van deze drie kenmerken.

Hiertoe volgen wij telkens drie analysestrategieën. In de eerste plats hanteren wij de multiple regressie-analyse. Deze techniek maakt het mogelijk, om de verbanden op te sporen, die er bestaan tussen de athankelijke en elke onafhankelijke variabele, warbij het effect van alle andere onafhankelijke variabelen geneutraliseerd wordt. Bovendien levert deze analyse-techniek ons inzlcht in de verklaringskracht van alle onafhankelijke variabelen gezamenlijk. Door deze regressie-analyse worden evenwel alleen de sterkste verbanden geselecteerd. Andere verbanden, die voor inzlicht in de gestelde problematiek ook van belang zijn, voldoen nlet aan de hoge eisen, die een regressie-analyse met 26 varlabelen stelt. Daarom verrichten wij daarnaast nog een aanvullende partiële correlatie-analyse, waarbij de in de regressie-analyse significant gebleken variabelen constant worden gehouden. Aldus krijgen wij nieuwe, max zwakkere verbanden met de afhankelijke variabele. Ten derde zullen wij-ook weex vila de techniek van de partiële correlatierekening- de onderlinge relaties in beeld brengen tussen de in de regressie- en aanvullende partiële correlatie-analyse slgnificant gebleken variabelen.

Voor wij in de paragrafen 7.3 tot en met 7.5 de resultaten van dit alles zullen bespreken, dienen wij eerst nog tekst 
en uitleg te geven over onze preciese werkwijze bij de regressie-analyses. Hierbij hebben wij namelijk een aantal theoretische overwegingen mee willen laten spelen. Deze verantwoording wordt gegeven in paragraaf 7.2 .

7.2. Theoretische overwegingen bij de regressie-analyses

Van de diverse manieren, waarop regressie-analyses vitgevoerd kunnen worden, hebben wij gekozen voor de zogenaamde hiërarchisch opgebouwde versie (Nie et al, 1975). Dat wil zeggen, dat wij de onafhankelijke variabelen per rubriek in de analyse betrekken en wel volgens een op theoretische gronden gekozen volgorde. Vanuit een sociaal-medisch standpunt bekeken, is het namelijk van belang om te weten, of ook andere variabelen dan alleen de aandoening invloed heeft op de hier te bestuderen kenmerken van de ziekteperiode.

Om deze vraag te beantwoorden, hebben wij de 4 kenmerken van de aandoening als eerste groep in de regressie-analyses ingevoerd. Pas daarna hebben wij de 4 andere variabelenrubrieken bij de analyses betrokken; zo kunnen wij zien, of het percentage door de aandoening verklaarde variantie substantieel opgehoogd wordt door toevoeging van de andere onafhankelijke variabelen.

Bij het opnemen van de 4 andere variabelenrubrieken hebben wij hetzelfde procedé gevolgd; ook daar hebben een volgorde aangegeven. Zo is onze basisveronderstelling, dat na de aandoening vooral de indicatoren van het gezondheidszorgaanbod van invloed zijn op respectievelijk het doorverwijscijfer, het antal verwijzingswachtdagen en het aantal stuurloze dagen (zie ook hoofdstuk 2). In derde instantie hebben wij de rubriek der persoonskenmerken bij de analyse betrokken, gevolgd door de kenmerken van de behandeling en de werkkenmerken. Op deze manier kan men de bijdrage van elke variabelenblok apart aan het totale percentage verklaarde variantie aflezen.

In figuur 7.1. geven wij ter verduidelijking van onze aanpak nog een theoretische ordening van verwachte relaties tussen de drie afhankelijke variabelen en de onafhankelijke variabelen-blokken. In deze grafische ordening hebben wij het tijdsperspectief gehanteerd; dit impliceert, dat de variabelen, die links zijn getekend, verondersteld worden in tijd 

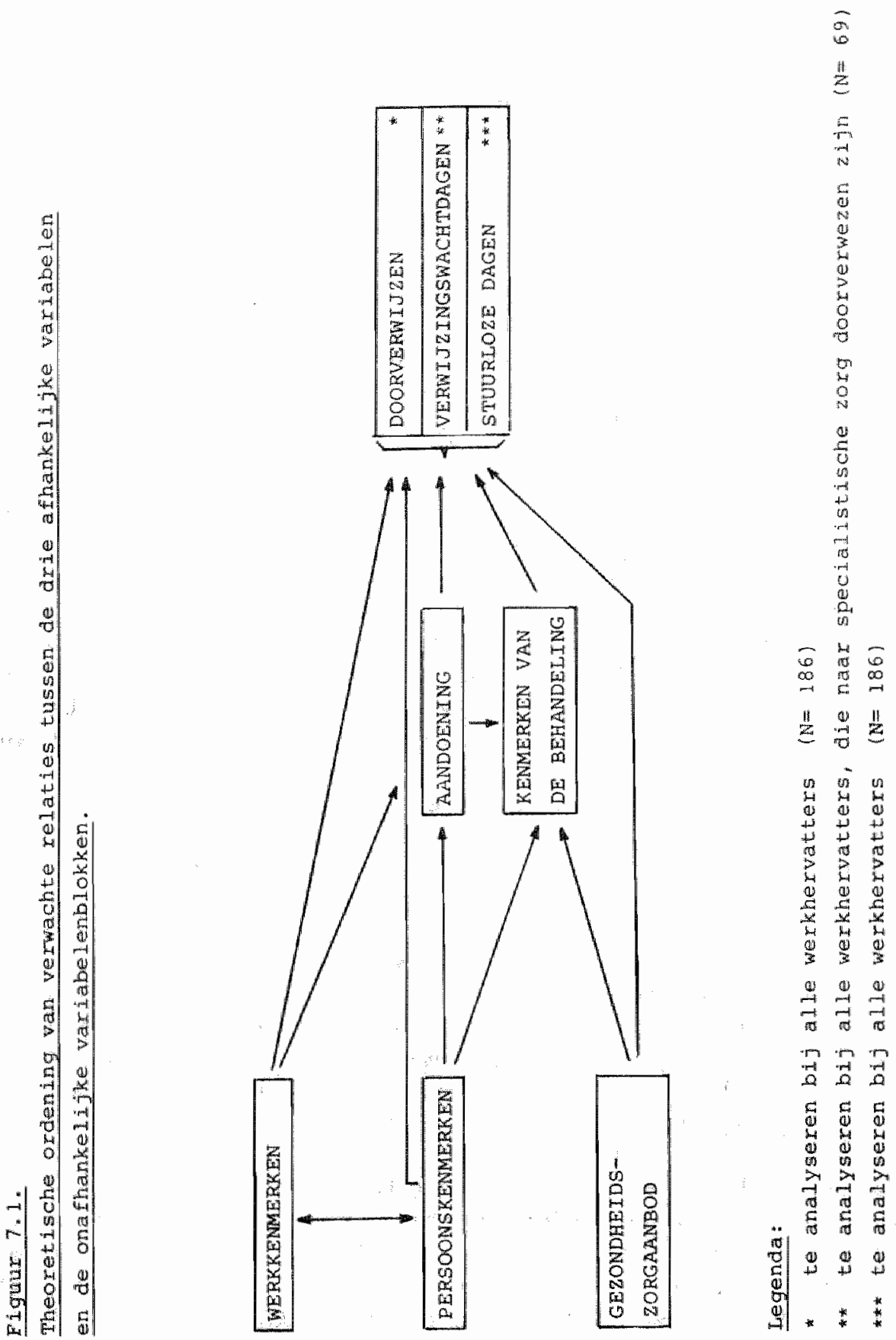
vooraf te gaan aan de variabelen, die rechts daarvan zijn weergegeven. Deze figuur zullen wij verderop gebruiken als leidraad voor de ordening van verbanden.

Tot slot van deze uitwijding over de werkwijze bij de analyse nog enkele methodisch-technische opmerkingen. De hier gebruikte hiërarchische versie van de multiple regressieanalyse mag niet verward worden met de zogenaande stapsgewijze methode. Deze laatste methode bepalt de volgorde van het opnemen der onafhankelijke variabelen in de regressie- vergelijking aan de hand van de statistische sterkte van het betreffende verband. Deze procedure hebben wij hier niet gevolgd.

Voor alle duidelijkheid: wij presenteren in de tabellen uitsluitend de gestandaardiseerde beta-coëfficiënten uit de laatste vergelijking; hierin zijn alle onafhankelijke variabelen opgenomen. Alleen de percentages verklaarde variantie per variabelenrubriek hebben betrekking op regressie-vergelijkingen met kleinere aantallen variabelen.

Een andere methodisch-technische kwestie betreft de verhouding tussen het aantal onderzoekseenheden en het aantal in de analyse te betrekken variabelen. Dit kan een precair punt zijn, omdat een te kleine verhouding tot toevallig significante uitkomsten kan leiden. Onze aanpak met 186 eenheden en 25 variabelen zou verdacht kunnen zijn, maar analyses met dezelfde of ongunstiger verhoudingen zijn al eerder verricht (b.v. Merens-Riedstra, 1981). Om toch met zekerheid het gevaar van toevallige uitkomsten te ontlopen, zullen wij bij elke analyse twee contrôles verrichten. Ten eerste zullen wij nagaan, of de significante resultaten uit de laatste regressie-vergelifking met alle onafhankelijke variabelen ook al voorkomen bij de vergelijkingen met kleinere aantallen variabelen. Ten tweede zullen wif -zoals eerder al gezegd- de significante verbanden uit de regressie-analyse opnieuw berekenen in de aanvullende partiële- correlatie-analyses. Bij deze laatste analyses zullen wij maximaal 7, max meestal slechts 4 of 5 variabelen tegelijkertija betrekken; gelet op de omvang var onze steekproef is dit laatste zonder meer een veilige anpak te noemen.

Tenslotte nog dit: ondat wij de directe versie van de multiple regressie-techniek gebruiken, is er geen sprake van multi-collineairiteitsproblematiek (Fielding, 1978); derhalve 
kunnen wij de onderling hoog gecorreleerde variabelen met betrekking tot de ziektekostenverzekering en de loondervingsregeling tegelijkertijd in de analyses betrekken.

\subsection{Het verwijscijfer}

Bij deze eerste verklarende analyse hebben wij geen gebruik gemaakt van alle 25 onafhankelijke variabelen. vier variabelen, te weten het aantal contacten met de huisarts -op elgen initiatlef van de patiënt dan wel na terugbestelling- alsmede het aantal contacten met specialisten en de opnamen, hebben wij hier bulten beschouwing gelaten. Dit hebben wij gedaan on tautologische resultaten te vermijden. Immers, per definitie zijn patiënten, die (poli)klinische contacten hebben, ooit doorverwezen en patiënten, die alleen in de eerste lijn behandeld worden, niet. Dit soort "kennis" hoeft onze analyse niet op te leveren. De overige 21 variabelen zijn wel in de analyse opgenomen, met het in tabel 7.1 weergegeven resultat.

De eerste conclusie, die deze tabel oplevert, betreft het percentage total verklaarde variantie. Dit percentage bedraagt 14.0 en lijkt op het eerste gezicht niet exg hoog. Niettemin steekt het niet ongunstig af ten opzichte van wat gebruikelijk is in onderzoek naar medische consumptie (bijv. v.d. Gaag, 1978). Het illustreert alleen maar, dat ter verklaring van verschillen in medische consumptie veel meer invloeden in het spel zijn dan doorgaans in sociaal-wetenschappelijk onderzoek zichtbaar wordt gemaakt. Men moet hierbij vanzelfsprekend vooral denken aan het effect van de uniciteit en het tijdstip van elk ziektegeval.

De opbouw van het percentage verklaarde variantie per variabelenrubriek is vrij gelijkmatig. Alleen de patiëntenkenmerken blijken niet zo'n grote rol te spelen. Corresponderend met de relatief lage verklaarde variantie blijken verder slechts twee variabelen in de regressie-analyse significante verbanden met het verwijscijfer op te leveren: 
Tabe 1.1

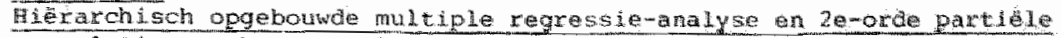

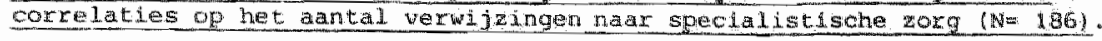

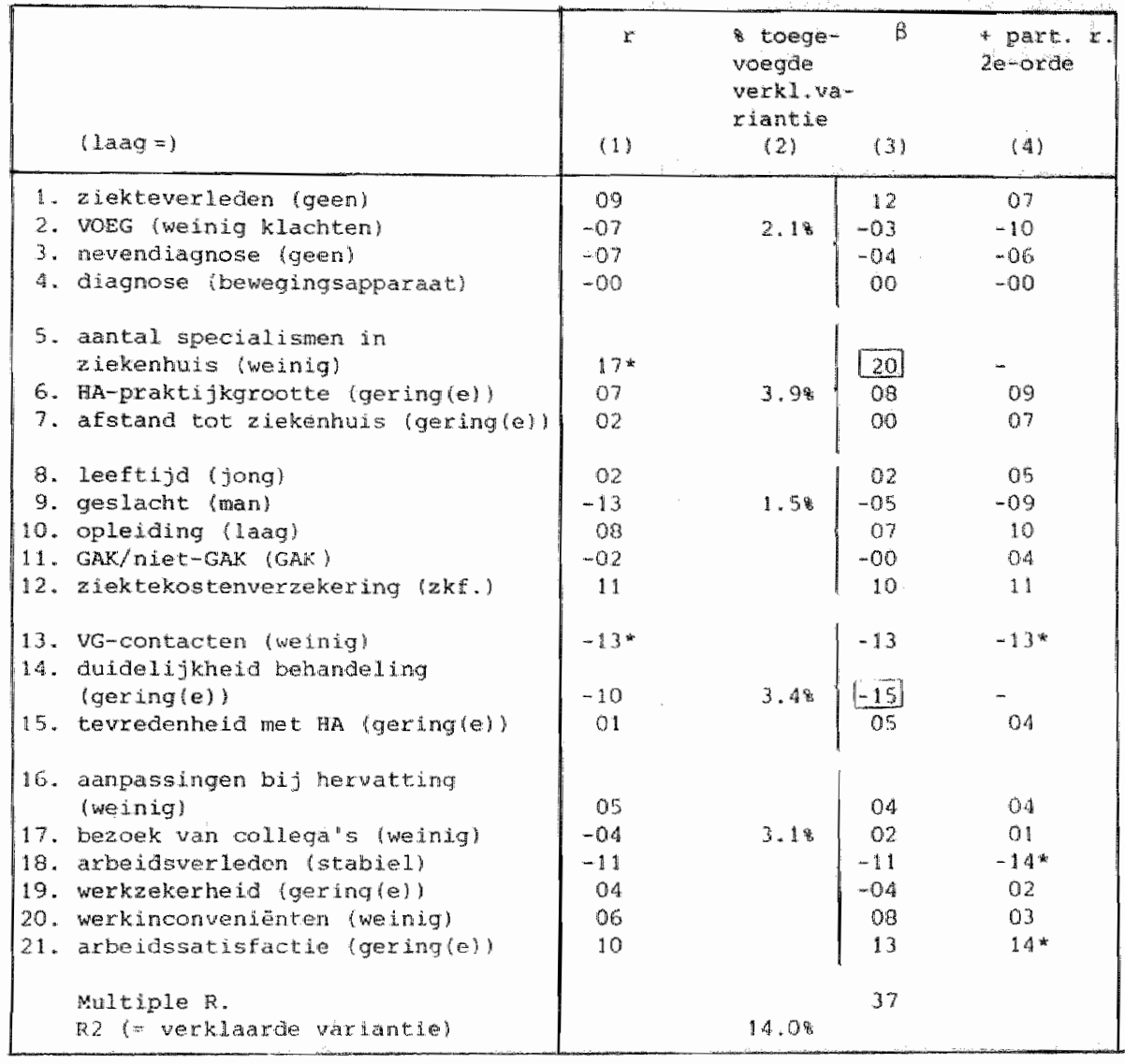

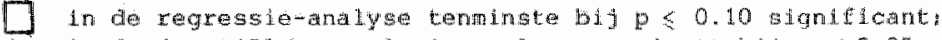

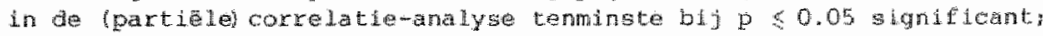
bij deze paxtiele correlute-rekeningen zijh de variabellen 5 en 14 constart gehouden. 
- het verwijscijfer is groter, naamate het aantal specialismen in het meest nabij gelegen ziekenhuis groter is, en verder

- naarmate de behandeling in het begin van de ziekteperiode als onduidelijker is ervaren.

Deze verbanden doen zich ook voor in de regressievergelijkingen met kleinere aantallen variabelen: daarin zijn ze nog sterker dan in de latste regressievergelijking, die gepresenteerd is in tabe1 7.1. Er is hier dus geen sprake van toevallige uitkomsten. Deze twee significante variabelen hebben wij constant gehouden bij de berekening van de aanvullende partiẹle correlatie-coëfficiênten (zie inleiding). Deze tweede procedure levert nog eens drile significante, maar minder beproefde verbanden met het verwijscijfer op. Voor alle duidelijkheid: deze verbanden zijn minder beproefd, omdat er slechts twee variabelen constant gehouden zijn.

Per rubriek volgt nu een bespreking van de in totaal $5 \mathrm{sig-}$ nificant gebleken verbander.

I. Van de kenmerken van de aandoening blijkt geen der variabelen van significante betekenis voor het verwijscijfer te zijn. Slechts is er een lichte aanwijzing, dat patiënten met een al langdurende aandoening vaker verwezen worden. Deze aanwijzing komt overeen met ander onderzoek (v. Vliet en V.d. Ven, 1982).

II. In de rubriek van indicatoren van het gezondheidszorgaanbod doet zich een uit ander onderzoek bekend verband voor. Naarmate het aanbod van specialistische hulp in het meest nabij gelegen ziekenhuis meer gedifferentieerd 1s, wordt men -ceteris paribus-vaker doorverwezen. Uit andere analyses op het datamaterial van dit onderzoek blifkt dat deze relatie algemener is: naarmate het aantal specialismen in het dichtstbljzijnde ziekenhuis groter is, wordt men niet alleen vaker naar de tweede lijn doorverwezen, maar is de contactfrequentie met de hulsarts geringer. Hiermee bevestigt dit onderzoek eens te meer, dat het aanbod van gezondheidszorgvoorzieningen mede van invloed is op de wijze, waarop patiënten behandeld worden.

Overigens, blijft het verwachte en elders vastgestelde effect ( $b . v$. Kruidenier, 1977) van de afstand tot het 
ziekenhuis op het verwijscijfer in ons datamateriaal achterwege. De verklaring hiervoor moet men waarschijnlijk zoeken in het geografisch beperkte gebied, waarin dit onderzoek is uitgevoerd. Vermoedelijk is nergens in -het dichtbevolkte- z-Limburg de afstand tot het ziekenhuis zo groot, dat deze van invloed is op de beslissing van de huisarts, om al dan niet door te verwijzen.

III. Van de rubriek der persoonskenmerken vertoont geen der variabelen een significante relatie met het doorverwijscijfer. Dit wijkt af van ander onderzoek, waarin effecten van geslacht en opleiding zijn vastgesteld (bijv. Rutten, 1978). Dat deze verbanden in ons datamateriaal niet naar voren komen, heeft te maken met de samenstelling van onze steekproef. Onze steekproef bevat uitsluitend zieke personeelsleden, terwijl de genoemde andere onderzoeken bevolkingsstudies zijn. Dit levert ten aanzien van de variabele "geslacht" nogal forse verschillen op. Wat het opleidingsnivo betreft, kan vermeld worden, dat het verband in deze analyse wel het verwachte teken heeft, maar het gehanteerde significantienivo niet haalt.

IV. In de rubriek kenmerken van de behandeling valt van twee significante verbanden melding te maken. Ten eerste blijkt het aantal contacten met de VG relatief kleiner te $z i j n$, wanneer men doorverwezen is. Misschien vinden VG-en het minder zinvol om contact te hebben met patiënten, die in de tweede lijn behandeld worden en wellicht daarom geacht worden meer objectieve aandoeningen te hebben (zie ook hoofdstuk 6). Anderzijds is het ook begrijpelijk, dat VG-en bij hun handelen moeten afgaan op de uitkomsten van specialistische diagnostiek en eventuele therapie, en daarop dan ook wachten. Ten tweede is het zo, dat vaker wordt doorverwezen, naarmate de behandeling aan het begin van de ziekteperiode als onduidelijker beleefd wordt. Dit verband komt overeen met wat men hieromtrent zou kunnen verwachten: juist patiënten, waarbij de huisarts (nog) geen therapie kan ontwikkelen en dus ook niet kan verauidelijken, worden doorverwezen. 
V. In de categorle variabelen, die betrekking hebben op het werk van de patiënten, kumnen opnieuw twee significante relaties gesignaleerd worden. Zowel patienten, ale en stabielere loopbaan achter de rug hebben, als patienten, die een grotere arbeidssatisfactie vertonen, worden vaker doorverwezen Mec deze beide verbanden wordt en bepala type patienten aangeduid, die -op zijn zachtst gezega-geen problemen in de sfeer van hun werk hebben. Juist dergelijke patienten zulien de aandoening, die ze opgelopen hebben, zo snel en wellicht ook zo gelegitimeerd mogelijk behandeld willen zien. Dit kan in hun perceptie, c.q. in die van hun huisarts vermoedelijk het best via een doorverwijzing. Aan de andere kant kan het zo zijn, dat in een steekproef van langdurig zieke werknemers degenen met een hoge arbeidstevredenheid juist de meest objectieve aandoeningen hebben; alt type aandoeningen leent zich bij uitstek voor behandeling in de tweede lijn.

Welke interpretatie de juiste is, valt moeilijk exact te bepalen. In leder geval vormt de eerste interpretatie een duidelijke aanwjuing voor de ook al elders gesignaleerde invloed van patienten bij het totstandkomen wan de beslissing, om al dan niet door te verwijzen (Ludke, 1982; Dopheide * Nijhout, 1983).

Tot zover de bespreking van de significante verbanden uit de regressie- en aanvullende partiéle correlatie-analyse. Zoals eerder aangekondigi, laten wij nu opnieuw een partiële correlatie-analyse volgen, dit keex an de verbanden tussen de onathankelijke variabelen onderling te kunnen bestuderen. Deze analyse hebben wij verricht met de zojuist significant gebleken 5 onafhankelijke variabelen en met vanzelfsprekend net verwijcijfer als afhankelijke variabele. Voor de relaties met het verwijscijfer gat het on 4 e-orde coéfficienten voor de verbanden tussen de onafhankelijke variabelen onderling gat het on correlaties van de 3e-orde. De opzet hierbij is om de zuivere verbanden tussen twee variabelen weer te geven, via uitschakeling van de invloeden van alle andere in de analyse betrokken variabelen, hoe klein die ook ziju.

In iguur 7.2. zijn de resultaten van deze analyse weergegeven. De conclusies, die men nat aaleiding van deze figuur 

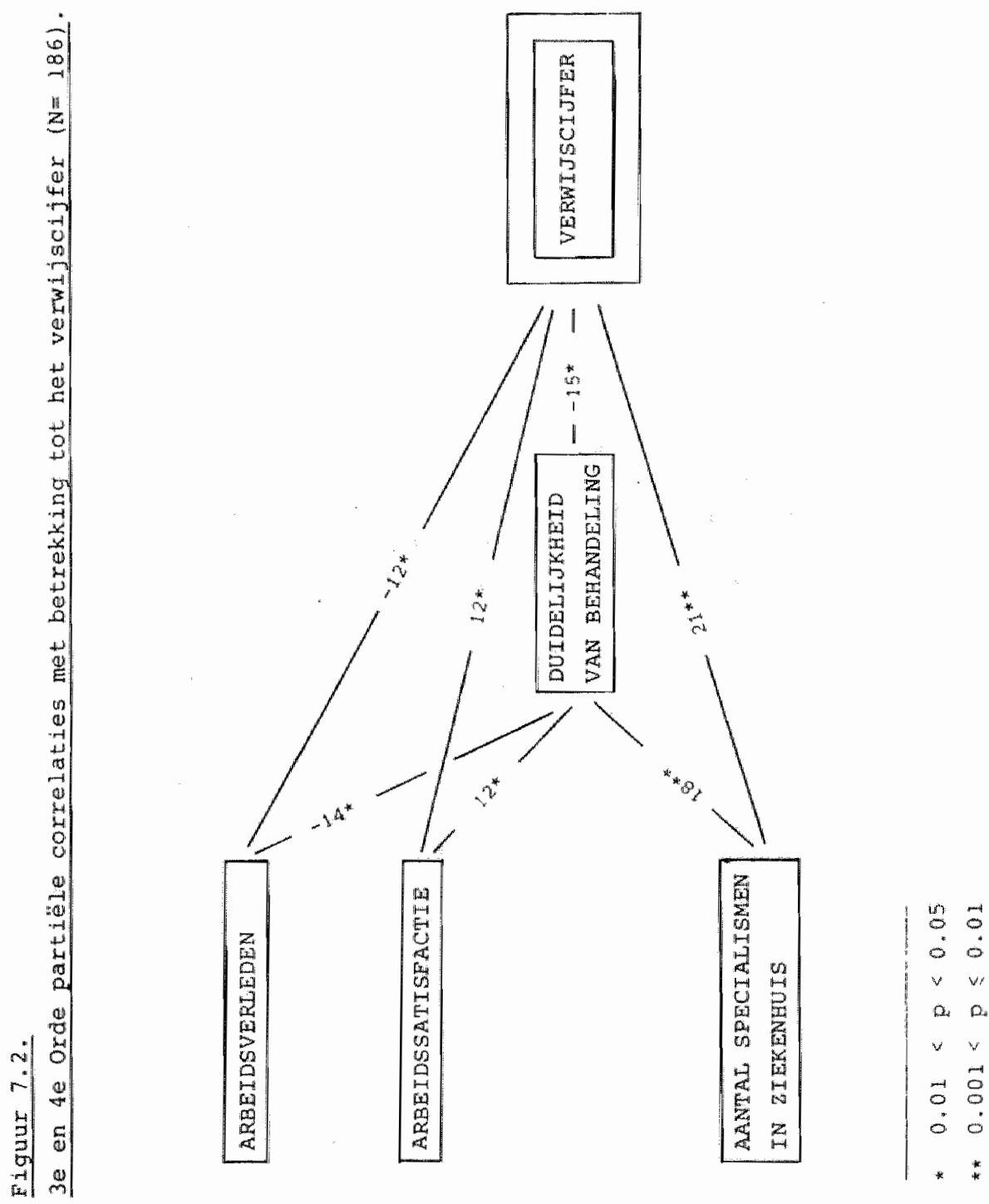
kan trekken, zijn natuurlijk voor een deel identiek aan hetgeen zojuist besproken werd. Zo zijn de verbanden tussen het verwijscijfer enerzijds en de differentiatie van de specialistische zorg, de duidelifkheid van de behandeling, de arbeidssatisfactie en het arbeldsverleden anderzijds identiek aan de resultaten uit de beide voorgaande analyses. Het eerder eveneens signiflcant gebleken verband tussen het verwijscijfer aan de ene kant en het aantal VG-contacten aan de andere kant, overschrijdt hier slechts de 10s-significantiearempel.

Men kan op grond van de in figuur 7.2. weergegeven relaties een tweetal nieuwe inzichten opdoen:

Naarmate men een grotere arbeidstevredenheld en een stabieler arbeldsverleden toont, heeft men de behandeling in het begin van de ziekteperiode duidelijker gevonden. Eerder hebben wij verondersteld, dat deze patiënten vaker objectieve aandoeningen hebben, die tot meer verwijzingen aanleiding geven. Men kan veronderstellen, dat bij dergelijke aandoeningen, warbij relatief snel doorverwezen wordt, de behandeling in het begin van de ziekteperiode relatief duidelijk wordt gevonden. Dat de aard van de aandoening inderdaad een doorkruisende factor in verband met deze relaties vormt, blijkt wel uit het feit, dat de partiële correlaties in kwestie niet meer significant zijn, wanneer ook het effect van de variabelen VOEG en ziekteverleden wordt uitgeschakeld (resp. werkverleden en duidelijkheid: $r=-11$, n.s. : arbeidssatisfactie en duidelijkheid: $r=06, n . s$.$) .$

- verder blijkt de behandeling in het begin van de ziekteperiode voor die respondenten duidelijker te zijn geweest, die dichtbij een ziekenhuis wonen, waarin verhoudingsgewijze meer specialismen vertegenwoordigd zijn. Dit verband blijft gehandhaafd zowel voor de patiënten, die hun ziekteperiode met specialistische contacten beginnen ( $r$-part $=.18$ ) als voor patiënten, die aanvanke$1 i j k$ in de eerste lijn terecht komen $(x-$ part. $=.22)$. Voor de eerste groep patiënten is dit verband goed begrijpbaar: daar waar de specialistische zorg meer gedifferentieerd is, is de behandeling duidelijker. Het verband voor de tweede groep patiënten wijst mogelijkerwijze op een andere -meer duidelijke- manier van werken van huisartsen in stedelijke gebieden (waar meex gespecialiseerde ziekenhuizen gevestigd zijn; zie hoofastuk 6). 
Hiermee sluiten wij de paragraaf over de verklaring van het verwijscijfer af.

\subsection{Verwijzingswachtdagen}

In deze paragraaf stellen wij de verwijzingswachtaagen aan de orde. Dit doen wij volgens dezelfde procedures, die wij in de vorige paragraaf gehanteerd hebben. Ex is echter een verschil: wij verrichten de analyse nu niet meer voor alle 186 werkhervatters, maar uitsluitend voor die respondenten onder de hervatters, die tenminste één keer naar specialistische hulp in de tweede of derce lijn verwezen zijn. Immers, juist voor deze categorie van patiënten kan het vraagstuk van de verwijzingswachtdagen een storende factor in het verloop van de behandeling betekenen. Het gaat hier om 69 patiënten.

Voor deze substeekproef hebben wij, precies zoals in de vorige paragraaf, ten eerste een hiërarchisch opgebouwde multiple regressie-analyse uitgevoerd; vervolgens hebben wij een aanvullende partiële correlatie-analyse verricht, onder constanthouding van de in de regressie-analyse significant gebleken variabelen. Tenslotte hebben wij een partiële correlatie-analyse uitgevoerd, om de onderlinge structuur van de relevante variabelen op te sporen.

De resultaten van de regressie-analyse staan weergegeven in tabel 7.2.; zij geven aanleiding tot de volgende conclusies. Ten eerste blijkt het percentage totaal verklaarde variantie een stuk hoger te zijn dan bij de analyse op het verwijscijfer. Niet minder dan 38.4\% van de totale variantie wordt gebonden door de 25 onafhankelijke variabelen. Hierbij blijken een drietal variabelenrubrieken een prominente rol te spelen. Het grootste gedeelte van de verklaarde variantie komt op naam van de kenmerken van de aandoening, terwijl ook de patiëntenkenmerken en de variabelen met betrekking tot het werk relatief veel variantie binden. Niettemin is ex slechts één significant verband. Dit verband betreft de variabele ziekteverleden en doet zich ook al voor bij regressie-vergelijkingen met kleinere aantallen variabelen; deze variabele is bij de aanvullende partiële correlatie-analyse uitgeschakeld. Op basis $\operatorname{van}$ de aanvullende analyse komen enkele 
Iabe 1.2 .2$.

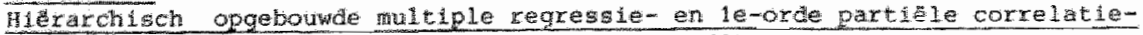

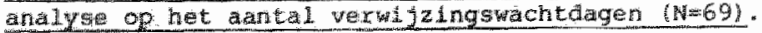

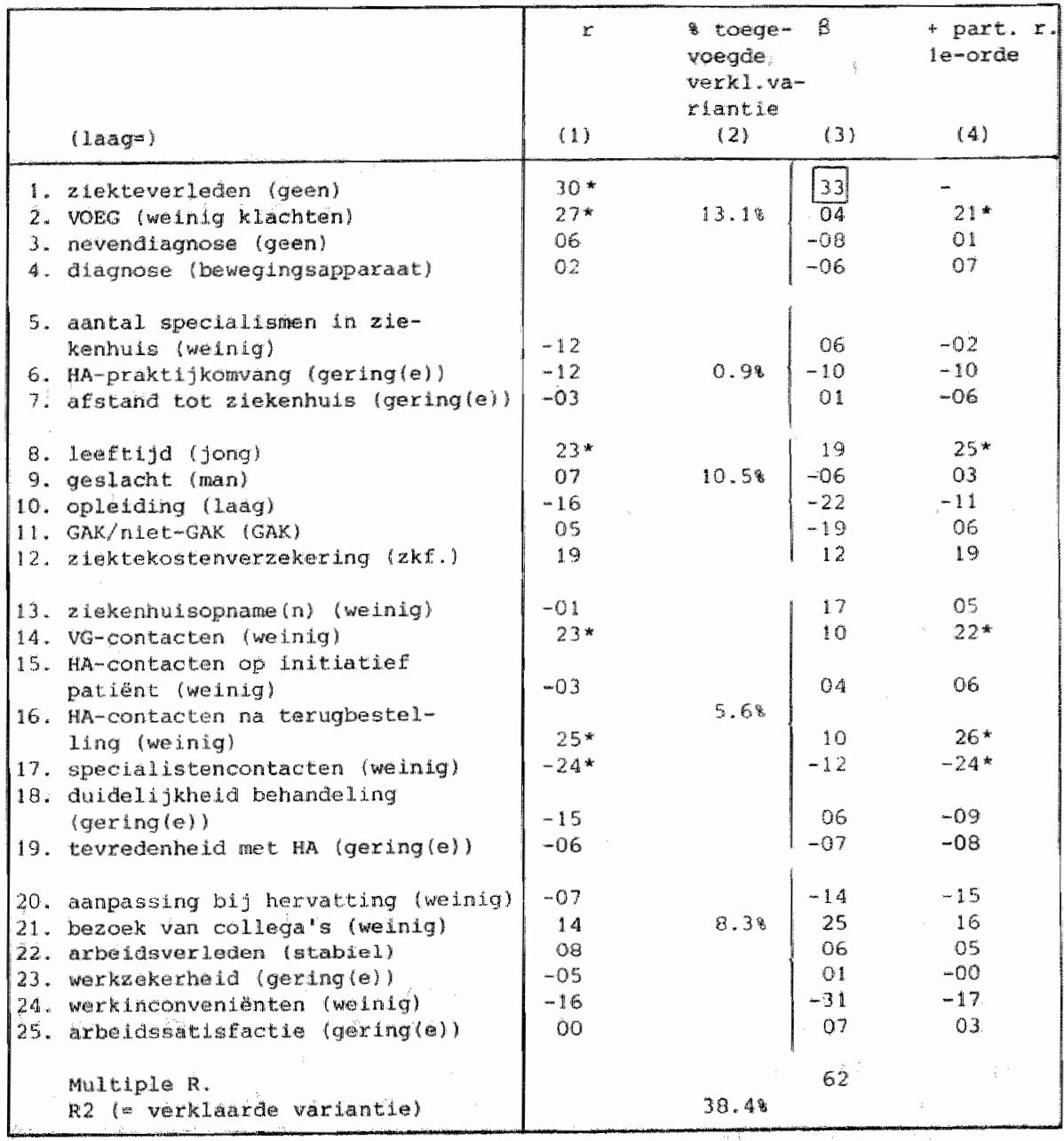

in de regressie-analyse bij $p \leqslant 0.10$ gignificant;

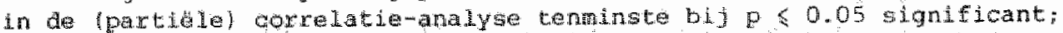

+ bij deze partiele correlatie-rekening is variabele 1 constant gehouden. 
nieuwe, maar zwakkere verbanden naar voren. Samen met het sterke effect van ziekteverleden worden deze nu per variabelenrubriek besproken.

I. In de rubriek der kenmerken van de aandoening doet zich het enige significante verband uit de regressie-analyse voor:

naamate de aandoening van de patiënt een al langer durend karakter heeft, is het aantal verwijzingswachtagen groter. Met andere woorden: patienten, die voor dezelfae aandoening al eerder verzuimd of een arts geraadpleegd hebben, maken meer verwijzingswachtdagen mee. Dit in tegenstelling tot patiënten, die acuut klachten hebben gekregen, zoals bij een ongeval of een hartinfarct. Dit verband komt overeen met wat men op basis van gezond verstand zou kunnen verwachten.

Verder blijkt uit de eerste-orde partiële correlatieanalyse, dat een hoge VOEG-score samengaat met relatlef veel verwijzingswachtdagen. Een verklaring voor dit verband moet men vermoedelijk zoeken in de wetenschap, dat hoge VOEG-scores wijzen op een sterke klaaggemeigdheid van de patiënten, die niet terug te voeren is op de aard van de aandoening (V.d. Zee, 1982; Visser, 1983); dit laatste is des te meer het geval vanwege de uitschakeling van de variabele ziekteverleden bij de berekening. Aldus lijkt deze positieve correlatie erop te wijzen dat de gezondheidszorg op een zodanige wijze reageert op overklagers, dat bij deze patiënten zich meer verwijzingswachtaagen voordoen (b.v. bij terugbestelling na een verrichting of bij ziekenhuisopnamen). overigens valt dit verband in de regressie-analyse volledig weg.

II. In de rubriek der indicatoren van het gezondheidszorgaambod valt van geen enkel significant verband melding te maken.

III.In de rubriek der patiëntenkenmerken doet zi.ch een significant verband voor op basis van de partiéle correlatie-analyse; dit verband handhaaft zich ook nog enigszins in de regressie-analyse. Het gaat om de aanwijzing, dat patiënten meer verwijzingswachtdagen meemaken, naarmate $z i j$ ouder $z i j n$. De achtergrond van dit verband zou gelegen kunnen zijn in een minder urgent type aandoenin- 
gen, dat oudere werknemers vaker zouden krijgen (vergelijk in dit verband de soortgelijke uitleg van het uitstelgedrag van ouderen: hoofdstuk 2). Aan de andere kant zou men kunnen veronderstellen, dat oudere patiënten in mindere mate beschikken over wat men wel burocratische vaardigheden zou kunnen noemen. Daarom zijn zij wellicht niet zo goed in staat, om afspraken te maken, die snel tot uitvoering komen (zie voor dezelfde problematiek bij uitkeringsgerechtigden: Filet, 1976).

IV. In de categorie der kenmerken van de behandeling doen zich drie signiflicante verbanden op grond van de partiele correlatie-analyse voor. Deze verbanden vallen evenwel in de regressie-analyse sterk weg. Het gaat om de volgende relaties: het aantal contacten met de VG en het aantal terugbestelcontacten bij de huisarts is groter, maar het aantal contacten met specialisten is verhoudingsgewijze kleiner, naarmate de verwijzingsperioden frequenter zijn en/of langer duren. Met name de eerste twee verbanden zijn opvallend. Kennelijk vinden zowel de VG als de HA het noodzakelijk om extra contact te hebben met verwezen patiënten, die niet onmiddellijk voor hun afspraak in de $2 e$ of $3 e$ lijn terecht kunnen.

V. In de rubriek der werkkenmerken -tenslotte- is geen sprake van variabelen, die hetzij in de regressie- hetzij in de partiële correlatie-analyse significant gerelateerd zijn aan het aantal verwijzingswachtdagen.

Hiermee sluiten wij de bespreking van deze analyse met betrekking tot het aantal verwijzingswachtdagen af. Ook nu weer presenteren wij een partiéle correlatie-analyse, om de onderlinge relaties van de 6 relevant gebleken variabelen zichtbaar te maken. Respectievelijk gaat het om $4 \mathrm{e}-$ en $5 e-$ orde correlaties met in totaal 6 onafhankelijke en 1 afhankelijke variabele. De resultaten van deze partiële correlatie-analyse zijn weergegeven in figuur 7.3.; alleen verbanden, die tenminste bij $\mathrm{p} \leqslant 0.05$ significant zijn, zijn aangegeven.

Ten eerste blijkt uit figuur 7.3., dat van de 6 eerder als significant aangeduidde variabelen er slechts één in de onderhavige analyse stand houdt. Dit betreft de variabele 

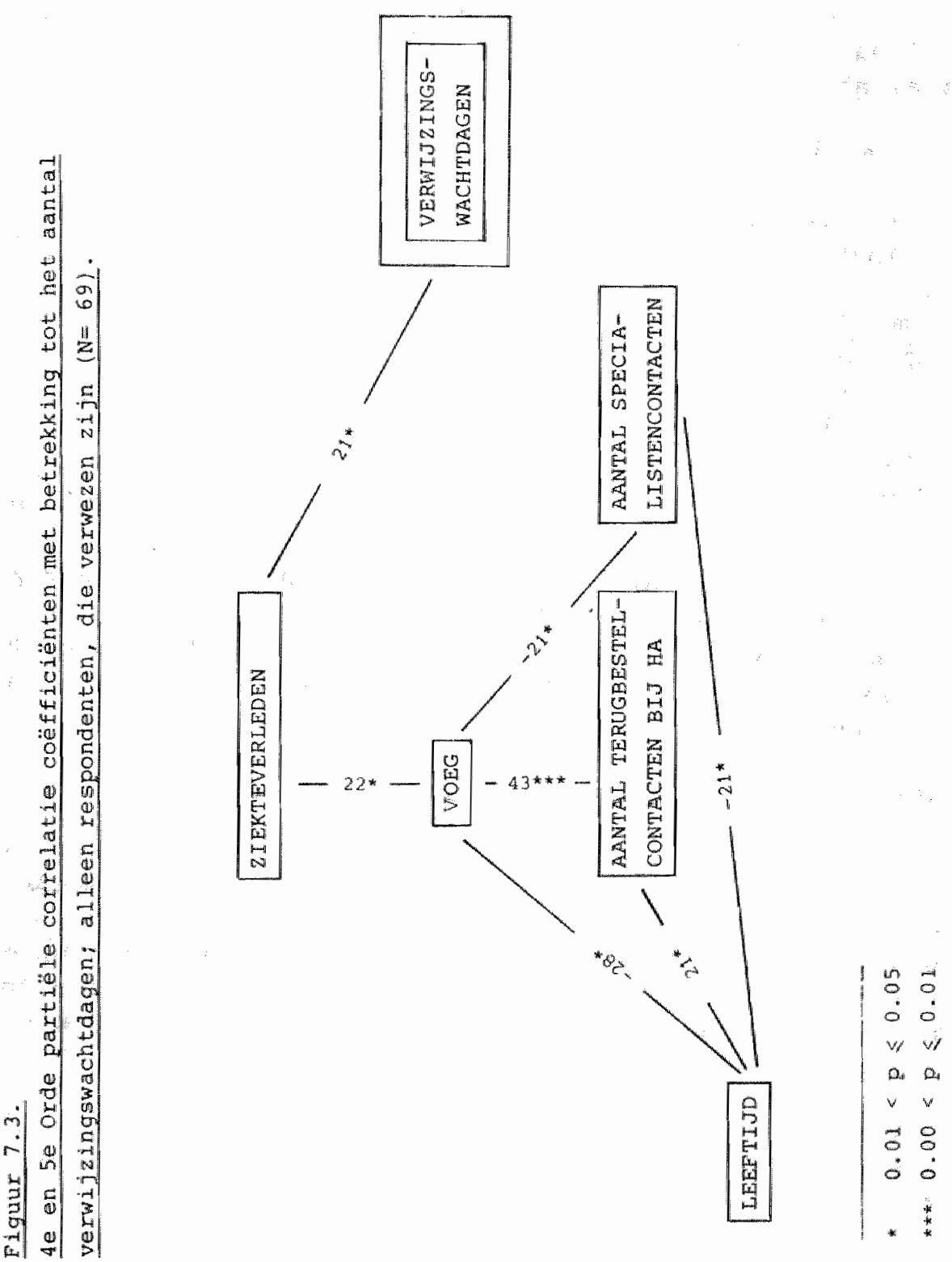
"ziekte-verleden". Dit is ook het enige verband, dat in de regressie-analyse naar voren kwam. De andere verbanden tussen verwijzingswachtdagen enerzijds en de VOEG, leeftijd, VG-contacten, specialistencontacten en HA-terugbestelcontacten anderzijas vallen hier -net zoals in de regressieanalyse-weg. Wat de verbanden met de 3 kenmerken van de behandeling betreft, deze vallen ook weg, wanneer slechts gepartialiseerd wordt voor ziekteverleden, leeftijd en de VOEG.

De 6 variabelen $z i j n$ wel verantwoordelijk voor een aantal interessante onderlinge relaties:

- ten eerste blijkt het aantal specialistencontacten verhoudingsgewijs groter te $z i j n$, naarmate de patiënten jonger zijn en lagere VOEG-scores hebben. Vermoedelijk vormen beide verbanden een artefact van de in dit onderzoek niet (goed) gemeten aard en ernst van de aandoening. Mogelijk hebben jongere patiënten en patiënten met lagere vOEG-scores meer objectieve aandoeningen ( $b . v$. ongevallen), die zich beter lenen voor behandeling in de tweede $11 j \mathrm{jn}$.

Het spiegelbeeld van deze beide verbanden wordt gevormd door twee andere verbanden: oudere patiënten en patiënten met hoge VOEG-scores worden vaker door de huisarts terugbesteld. Dat patiënten met relatief hoge VOEG-scoreg vaker door de huisarts worden terugbesteld, strookt met wat gemeten wordt via de VOEG-klachtenlijst. Volgens v.d. Zee (1982) vormt een VOEG-score een uiting van de klaaggenelgdheid van de betrokkene, en minder een indicatie van de objectieve gezondheidstoestand. Men mag dan ook aannemen, dat patiënten, die via de voEG-lijst over hun gezondheid klagen, dit ook bij hun huisarts zullen doen. Dat huisartsen diffuus klagende patiënten eerder zullen terugbestellen, is dan niet onbegrijpelijk.

- integenstelling tot wat men wellicht in eerste instantie zou verwachten blijken oudere patiënten minder klachten op de VOEG-lijst aan te geven dan jongere respondenten (zie voor dezelfde bevinding op basis van een bevolkingsstudie: V.d. Zee, 1982).

- tenslotte is het oud nieuws, dat patiënten met een al langer durende aandoening hoger op de VOEG-lijst scoren (zie ook hoofdstuk 6). 
Hiermee sluiten wij deze bespreking omtrent de oorzaken van verschillen in verwijzingswachtdagen tussen patiënten af. Alles overziende levert deze analyse het beeld op van een in dit opzicht efficiënt functionerende gezondheidszorg. ofschoon er blijkens hoofdstuk 4 wel verwijzingswachtdagen in z-Limburg bestaan, komen die niet nadrukkelijk ten koste van bepaalde patiëntencategorieën. Het ene verband uit de regressie-analyse wijst er alleen op, dat bij eventuele knelpunten in verwijzingswachttijden prioriteiten gesteld worden op grond van het acute karakter van de aandoeningen. Met andere woorden: eventueel onvermijdelijke lange verwijzingswachtperioden komen alleen bij die patiënten voor, waar behandeling van de aandoening inderdaad ook (enig) ditstel kan velen (zie ook Frost, 1980). De aanwijzingen, dat overklagers en oudere patiënten ook iets meer verwijzingswachtdagen dan gemiddeld meemaken, kan men op dezelfde wijze interpreteren.

Overigens blijven de bevindingen uit hoofdstuk 4 met betrekking tot langere verwijzingswachttijden voor patiënten in bepaalde diagnosecategorieën (bewegingsapparaat) hier onaangetast. De diagnose-variabele die in de zojuist gepresenteerde multivariate-analyse gebruikt is, is immers te grof, om dergelijke specifieke conclusies hier opnieuw te vinden.

\subsection{De stuurloze periode( $(n)$}

In deze paragraaf volgt de bespreking van de laatste analyses uit dit hoofdstuk. Deze betreffen de zgn. stuurloze da gen; dit zijn de dagen in een ziekteperiode, die verlopen zonder dat enig behandelingsplan wordt uitgevoerd of uitgezet. Deze analyses worden verricht bij de 186 werkhervatters en volgen hetzelfde stramien als in de twee voorgaande paragrafen. Dit impliceert, dat nu allereerst de bespreking van de multiple regressie-analyse volgt, zoals die is weergegeven in tabel 7.3 .

De eerste constatering betreft -zoals gebruikelijk- het percentage totaal gebonden variantie. Dit percentage bedraagt 21.4 en is hoger dan bij de analyse op het verwijscijfer, maar minder hoog dan bij de analyse op de verwijzingswachtdagen. Alleen de rubriek der indicatoren van het gezondheidszorgaanbod draagt slechts in geringe mate bij aan dit 
Tabe 1 7.3.

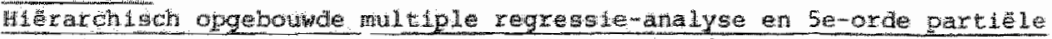

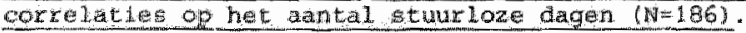

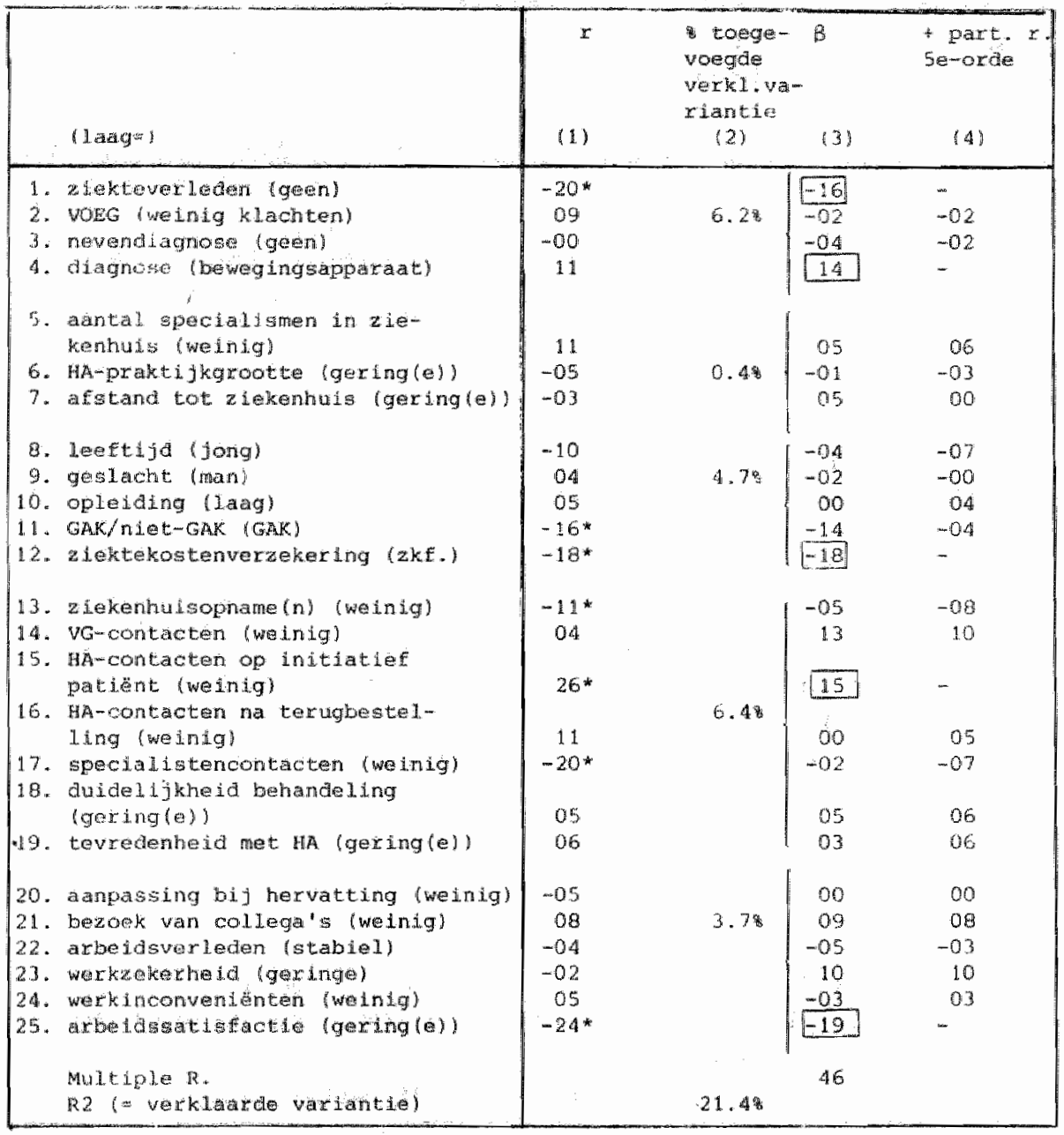

7 it de regreside-malyse teminge bij $p \leqslant 0.10$ significant;

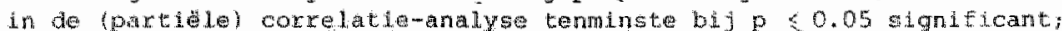

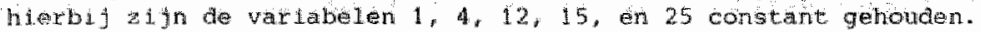


totaalpercentage, terwijl de patiëntenkenmerken en de variabelen met betrekking tot de behandeling een relatief grote bijdrage leveren.

De regressie-analyse levert in total 5 significante verbanden met de afhankelijke op. Deze verbanden doen zich ook voor in regressie-analyses met kleinere aantallen variabelen. Dit aantal wordt niet verhoogd door de aanvullende partiële correlatie-analyse. Men mag de regressie-analyse derhalve als volledig en succesvol bestempelen.

I In de categorie der kenmerken van de aandoening doen zich twee significante verbanden voor. Ten eerste blijkt men meer stuurloze dagen tijdens zijn ziekte mee te maken, wanneer men een aandoening heeft, die zich nog niet eerder bij de betreffende patiënt heeft voorgedaan. Dit verband vormt een aanvulling op eerdere constateringen, dat juist de meer chronische aandoeningen vaker verwezen worden en ook meer verwijzingswachtdagen meemaken. Kennelijk impliceert een ziekteverleden ook een behandelingsverleden, dat men weer snel kan oppakken.

Stuurloze dagen komen kennelijk vaker voor bij een ander type klachten. Deze klachten kenmerken zich -zoals gezegd- enerzijds door hun niet-chronisch karakter, maar anderzijds door het feit, dat ze wijzen op een aantasting van de algemene lichamelijke conditie en niet zozeer op een beperking van de mogelijkheden van het bewegingsapparaat. Deze uitkomst sluit aan op de bevinding uit hoofdstuk 4 , dat vooral patienten met psychische diagnosen veel stuurloze dagen meemaken.

II De categorie der indicatoren van het gezondheidszorgaanbod draagt slechts in geringe mate bij aan het totaalpercentage verklaarde variantie. Ex is dan ook geen sprake van ook maar enig significant verband in deze rubriek. Dit geeft aan, dat het probleem van stuurloosheid geen gevolg is van een kwantitatieve onderbezetting in de gezondheidszorg, maar eerder duidt op een kwalitatief afstemmingsvraagstuk (zie ook hoofdstuk 2).

III In de rubriek dex patiëntenkenmerken doet zich één verband voor: ziekenfonds-verzekerden maken meer stuurloze dagen mee dan particulier verzekerden. Daarnaast is er 
-ook weer in aansluiting op hoofdstuk 4- een zekexe aanwijzing, dat GAK-verzekerden meer dan ambtenaren en werknemexs in de gezondheldszorg stuurloze perioden meemaken. ook al vanwege het felt, dat beide variabelen een forse intercorrelatie vertonen (zie hoofdstuk 6), wijzen deze twee verbanden erop, dat stuurloze dagen bij een bepaald type patienten vaker voorkomen. Dit type patiënten kenmerkt zich, doordat het vooral werkzaam is bij het particuliere bedrijfsleven en dus niet bij overhelds- en gezondheidszorginstellingen, en bovendien doordat het geen bijzonder hoge inkomsten verwerft.

IV Van de kenmerken van de behandeling blijkt ook weer één variabele significant te correleren met het aantal stuurloze dagen. Men gaat vaker uit eigen initiatief naar de huisarts, naarmate men meer stuurloze dagen meemaakt. Heel duidelijk valt hier te zien, op welke wijze de patiënten een einde aan de stuurloze periode(n) proberen te maken, zonder dat dit evenwel goed lukt. Verder is er een bescheiden aanwijzing, dat VG-en vaker contact met hun verzekerden hebben, naarmate er sprake is van meer stuurloze dagen. Hieruit kan men afleiden, dat ook VG-en trachten de stuurloze perioden te verkorten of te beëindigen. Deze laatste aanwijzing is vooral belangrijk, omdat hiermee een veronderstelling uit hoofdstuk 4 aangaande het groter aantal stuurloze dagen bij GAK-verzekerden verworpen wordt. Daar is namelijk verondersteld, dat het geringer aantal contacten van GAK-verzekerden met hun VG-en één van de oorzaken van hun groter aantal stuurloze dagen zou zijn. Nu blijkt juist van de omgekeerde relatie sprake te zijn.* Hieruit en uit de tot dusverre besproken verbanden volgt, dat het ontstaan van stuurloze perioden vooral samenhangt met kenmerken van de patiënten en hun klachten en niet met een geringe contactfrequentie tussen VG en patiënt. Overigens, zijn inhoudelijke aspecten van de VG-patiënt-interactie niet in deze analyses opgenomen.

deze positieve relatie blijft intact, wanneer men de analyse uitsluitend voor de GAK-verzekerden onder de hervatters verricht. 
Ook over de veronderstelde effecten van het door GAKvG-en vaker gehanteerde "oproep-volgt-systeen" (zie hoofdstuk 4) zijn op basis van onze regressie-analyse geen nadere of meer definitieve uitspraken te doen.

V Dat variabelen, die men moet situeren aan de kant van de patiënten zelf, invloed uitoefenen op het ontstaan en de lengte van stuurloze perioden, blijkt ook weer uit de resultaten in de rubriek der werkkenmerken. Dit komt vooral naar voren in het gegeven, dat patienten meer stuurloze dagen meemaken, naarmate men minder tevreden over zijn of haar werk is. Hieruit spreekt wellicht de suggestie, dat degenen, die een geringere axbeidssatisfactie vertonen, niet zo snel geneigd zijn, om een einde aan de stuurloze periode( $n)$ te maken, teneinde herrieuwde behandeling of zelfs werkhervatting te bespoedigen. Aan de andere kant is het bepaald niet ondenkbaar, dat julst deze patiënten klachten presenteren, warmee men in de gezondheidszorg niet goed raad weet. Hierop komen wij verderop in deze paragraaf terug.

Overeenkomstig de werkwijze in de beide vorige paragrafen volgt nu nog een partiële correlatie-analyse, om de onderlinge structuur van de 5 significante variabelen op te sporen. Bovendien hebben wij in deze analyse 2 andere -relevant te achten- variabelen opgenomen; dit zijn de opleiding en de VOEG-score. Derhalve zijn -samen met de afhankelijke variabele- 8 vaxiabelen bij de berekeningen betrokken. Het gaat hierbij om $3 e-$ en 4 e-orde correlaties; deze leveren in totaal 14 significante relaties op, zoals figuux 7.4. laat zien. Ten eerste behoren hiertoe de 5 significante relaties met het aantal stuurloze dagen, zoals die ook al in de regressie-analyse naar voren waren gekomen.

Nog eens samenvattend betekent dit, dat patiënten, die relatief veel stuurloze dagen tijdens hun ziekte-periode meemaken, gekenmerkt worden door het feit, dat

- zij een aandoening zonder verleden hebben, d.w.z. een aandoening, waarvoor zij niet eerder verzuimd of een arts geconsulteerd hebben;

- zij een aandoening hebben, die wijst op een algemene lichamelijke malaise-toestand en niet zozeer op een specifieke bepexking van het bewegingsapparaat; 


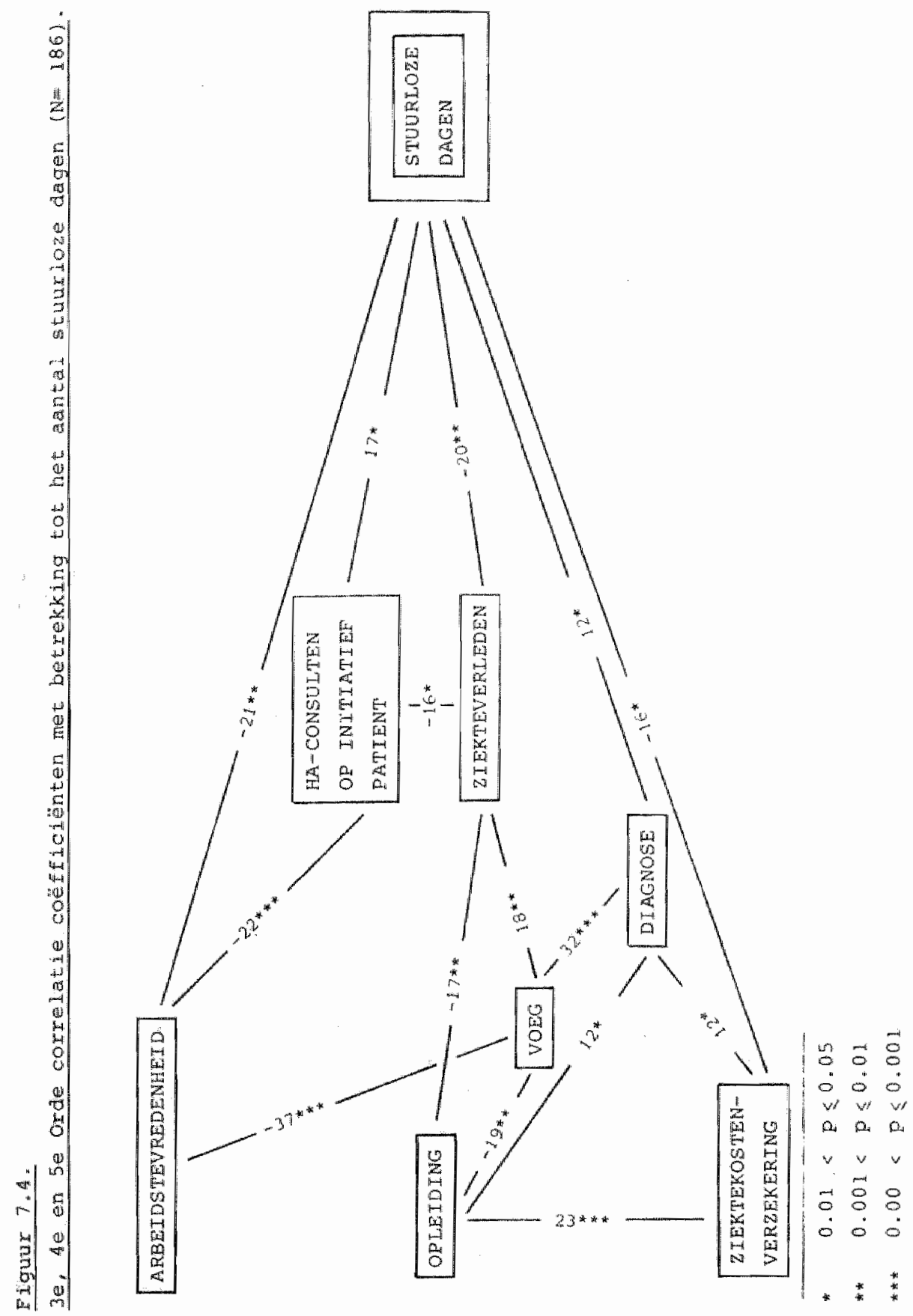




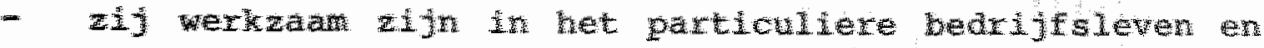

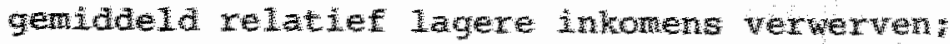

- zij een geringere arbeldsatisuctie hebben en

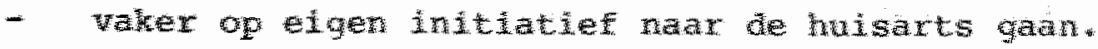

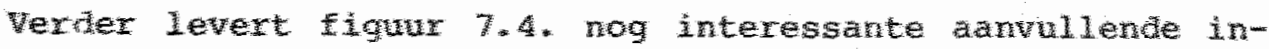

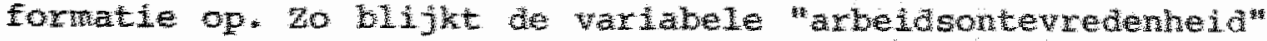

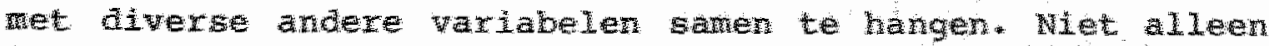
is het 20. dat aegener met en geringere arbelassabsacte

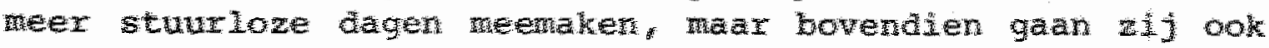

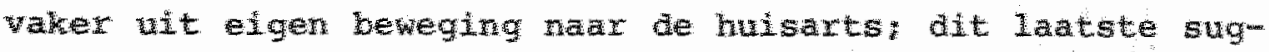
gereert, dat deze patienten hu klachen, die vemoedelik samenhangen net problemen in hus wer wel in het nedinch

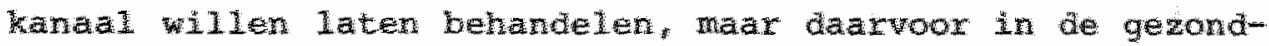
heidszorg geen oploseing, gexicht op werknervating vaden

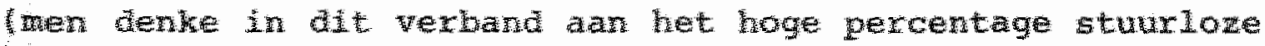

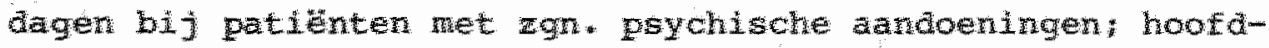

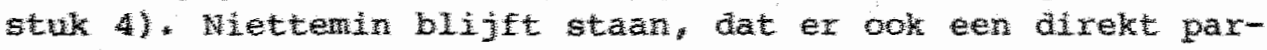

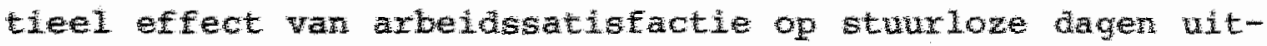

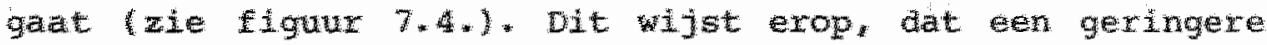
axbeldsetisfacte ex toch ook toe laldt at men minder po-

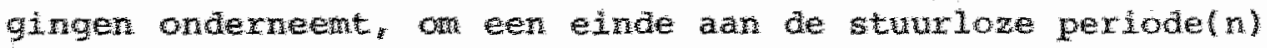
te maten.

Andere ciusters van renanden die uit figur 7.4 . nax voren komen, ain bexpet ats volgt te verworden:

- natrute de patuten en lager opleidingenuvo hebben

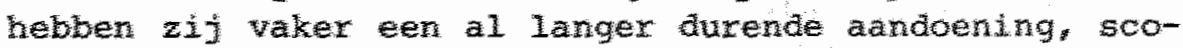

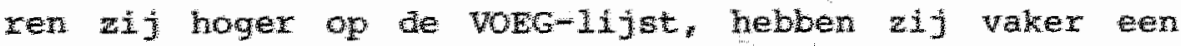
aandoening aan het bewegingsapparaat (incl. ongevallen) en zijn zij vakex ziekenfondsverzekerd. De latatgenoemde relatie hebben wij al eerder gezien en behoeft ook nauwelijks toelichting. De drie eerste verbanden wijzen erop, dat lager opgeleidden een grotere kans op zlekteaanbod hebben, -naar algemeen wordt angenomen- als gevolg van slechtere leef-en werkomstandigheden (Sultan \& Enos, 1977, Morr1s, 1980) (zie voor eenzelfde interpretatie met betrekking tot de hogere medische consumptie van ziekenfondsverzekerden: Mootz, 1978, 1980; zie ook Adriaanse e.a., 1981).

- verder blijkt opnieuw, dat een hoge volG-score samen gaat met een al langer durende aandoening alsmede met aandoeningen, die wijzen op een algehele lichamelijke malaise (zie ook hoofdstuk 6). 
- figuur 7.4. Wijst bovendien uit, dat degenen met een hoge arbeidstevredenheld en lage vOEG-score hebben. Kennelijk gaat een geringe arbeidssatisfactie samen met het uiten van ontevredenheid over de eigen gezondheid. Dit komt overeen met de suggestie van Visser (1983), die beweert dat de VOEG ook een uiting kan zijn van psychische en sociale spanningen.

- tenslotte: de patiënten, die een aandoening zonder verleden hebben, gaan verhoudingsgewijs vaker op eigen initiatief naar de huisarts. Dit gegeven spoort weer met de in par. 7.3. gevonden aanwijzing, dat respondenten met een langer ziekteverleden juist vaker worden doorverwezen.

Aan het einde van deze paragraaf willen wij onze bevindingen aangaande de stuurloze perioden confronteren met de literatuur omtrent uitstelgedrag. In hoofdstuk $2 \mathrm{zijn}$ wij immers van de gedachte uitgegaan, dat het ontstaan van stuurloze perioden deels op deze zelfde problematiek terug te voeren valt. Inderdaad lijken er aanwijzingen te zijn, dat er verwantschap tussen beide vormen van patiëntengedrag bestaat. Immers, uitstel van doktersbezoek na het signaleren van de eerste symptomen van een aandoening duurt langer, naarmate men zichzelf minder ernstig ziek vindt (bijv. Cassee, 1973). Hier hebben wij geconstateerd, dat stuurloze dagen vaker voorkomen, wanneer men een aandoening zonder verleden heeft. Indien men de duur van een aandoening tenminste voor een deel wil opvatten als een indicatie van de ernst ervan, is de overeenkomst duidelijk. Een tweede punt van verwantschap betreft de relatie tussen uitstelgedrag en een sterk gevoel van onwelbevinden aan de ene kant (Jessen, 1974) en stuurloze dagen en geringe arbeldssatisfactie aan de andere kant. In belde gevallen -kan men zeggen-, hebben mensen met een gevoel van onbehagen of geringe tevredenheid met het werk, de neiging om op problemen te reageren met ontkenning of vluchtreacties.

Toch is de overeenkomst tussen uitstelgedrag en stuurloosheid nadrukkelijk ook aan beperkingen onderhevig; immers patiënten proberen aan stuurloosheid een einde te maken door vaker naar de HA te gaan. Dit laatste doen "uitstellers" nu juist niet. 
7.6. Samenvatting

In dit hoofdstuk is een dxietal verklarende analyses verricht. Achtereenvolgens is het verwijscijfer, het aantal verwijzingswachtdagen en het aantal stuurloze dagen aan nadere analyse onderworpen.

Deze analyses hebben de volgende inzichten opgeleverd; voor interpretaties van de resultaten zij naar voorgaande tekst verwezen.

I. Ondubbelzinnig is via regressie-analyse angetoond, dat patiënten relatief vaker naar specialistische zorg in tweede of derde lijn worden verwezen, wanneer:

- het aantal specialismen in het meest nabije ziekenhuis verhoudingsgewijze groter is; en

- de behandeling in het begin van de ziekteperiode als onduidelijker is ervaren.

verder is er een aanwijzing gevonden, dat relatief meex verwijzingen plaatsvinden, naarmate:

- de patiënten een grotere arbeidssatisfactie vertonen en een stabieler arbeidsverleden hebben.

Tenslotte is de indruk gevestigd, dat een hoger verwijscijfer gepaard gaat met een geringer aantal contacten met de VG.

II. Ondubbelzinnig is via regressie-analyse aangetoond, dat doorverwezen patiënten langer moeten wachten op de realisering van die verwijzing, wanneer

- zij een aandoening met een verleden hebben, d.w.z. een aandoening waarvoor zij al eerder verzuimd of een arts geraadpleegd hebben. Deze aandoeningen staan in tegenstelling tot acuut ontstane klachten, zoals bij ongevalien.

III. Ondubbelzinnig is via regressie-analyse vastgesteld, dat patiënten verhoudingsgewijze meer stuurloze dagen meemaken, wanneer:

- zij een aandoening zonder verleden hebben, d.w.z. een aandoening, waarvoor zij nog niet eerder verzuimd of een arts geraadpleegd hebben, 
- zij een aandoening hebben die niet terug te voeren valt op een beperking van het bewegingsapparaat, zenuwstelstel en zintuigen of het gevolg is van eer ongeval.

- zij verplicht bij een ziekenfonds vexzekerd zijn, dat wil zeggen wanneer $z i j$ in particuliere bedrijfsleven werkzaam zijn en geen bijzonder hoge inkomens verwerven;

- zij een geringere arbeidssatisfactie vertonen. Verder is ondubbelzinnig vastgesteld, dat patiënten, die relatief veel stuurloze dagen meemaken, vaker wit eigen beweging naar de huisarts gaan. 
HOOFDSTUK 8.

DE VERKLARING VAN DE VERSCHILLEN IN ZIEKTEDUUR.

8. 1. Inleiding

In dit tweede hoofdstuk met verklarende analyses stellen wij de ziekteduur in het middelpunt van onze belangstelling. Hiermee bereiken wij de kern van het onderzoek, want om de oorzaken van lange ziekteduren is het in feite toch allemal begonnen (zie hoofdstuk 1).

Wij richten onze aandacht uitsluitend op de ziekteduren van de hervatters, zoals wij in hoofdstuk 6 al aangekondigd hebben. Bij de niet-hervatters heeft de ziekteproblematiek nogal eens een vermenging ondergaan van effecten van vervroegde of gedwongen uittreding. Bovendien achten wij het aantal niet-hervatters $(N=27)$ te klein, om op basis daarvan verantwoorde uitspraken te kunnen doen.

De werkwijze in dit hoofdstuk is volledig identiek aan die in hoofdstuk 7. Dit betekent, dat wij allereerst de resultaten van een hiërarchisch opgebouwde multiple regressie-analyse zullen presenteren. Hierbij zullen wij evenwel de 5 variabelenblokken in een lets andere volgorde in de analyse opnemen dan wij in het vorige hoofdstuk hebben gedaan. Na de kenmerken van de aandoening hebben wij achtereenvolgens de behandelings-, persoons-, en werkkenmerken en tenslotte de indicatoren van het gezondheidszorgaambod in de analyse opgenomen. Deze laatste rubriek achten wij namelijk pas in laatste instantie van invloed op de ziekteduur. Bovendien hebben wij éen onafhankelijke variabele vervangen door een andere; tekst en uitleg over dit laatste wordt verderop in dit hoofdstuk gegeven. Vervolgens verrichten wij onder constanthouding van de in de regressie-analyse significant gebleken variabelen een aanvullende partiële correlatiemana1yse. Hiermee handhaven wij de werkwijze, die in hoofdstuk 7 gevolgd is.

Na deze beide analyses zullen wij het datamateriaal verder exploreren. Dit zal wederom gebeuren via partiële correlatie-analyses. 
8.2. De multiple regressie-analyse

In tabel $8.1 \mathrm{zijn}$ de resultaten van de regressie-analyse weergegeven. Het percentage total gebonden variantie bedraagt 25, in vergelijking met de onderzoeken van wiersma (37\%), Merens-Riedstra (37\%) en de Jong e.a. (30\%), is dit percentage wellicht aan de lage kant.

Hierbij moet men evenwel bedenken, dat in vergelijking met deze onderzoeken onze steekproef heterogener qua samenstelling is: ex zijn bij onze studie immers ook vrouwen en ambtenaren betrokken. Daar staat tegenover dat bij de beide eerste onderzoeken ook WAO-intreders zijn betrokken; hiermee is in vergelijking met onze analyse onder uitsluitend hervatters in die onderzoeken de variantie en daarmee de verklaringsmogelijkheid van de zlekteduur groter. Ten derde hebben wij er in onze analysestrategie niet naar gestreefd, om het percentage totaal verklaarde variantie te maximaliseren. Belangrijker dan dat vinden wij het namelijk, om een helder overzicht te kxijgen van het effekt van de patiëntgezondheidszorg-interactie op het langdurig ziekteverzuim. Bij een dergelijke keuze van een zwaartepunt in onderzoek is beperking van het aantal onafhankelijke variabelen geboden en is het percentage totaal gebonden variantie derhalve nooit maximal.

De regressie-analyse levert in totaal vier significante verbanden op. De ziekteduur is relatief langer bij die patiënten, die

- minder contacten op eigen initiatief met de huisarts hebben:

- meer tevreden zijn over het functioneren van de huisaxts;

- het werk met meer aanpassingen hervatten; en

- wier huisarts gemiddeld genomen een kleinere praktijk heeft.

voor al deze vier verbanden geldt, dat ze zich ook al voordoen in regressie-vergelijkingen met kleinere aantalien variabelen.

Zoals gebruikelijk, hebben wij de werking van deze vier significante variabelen bij de aanvullende partiële correlatieanalyse uitgeschakeld. Deze aanvullende berekening levert nog eens 7 nieuwe verbanden met de ziekteduur op. 
Tabel 8.1.

Hierarchisch opgeboube tuliple regressie-analyse op zlektedut alleen hervatites $(N=186)$. Nethode: gewone kleinste kadrater.

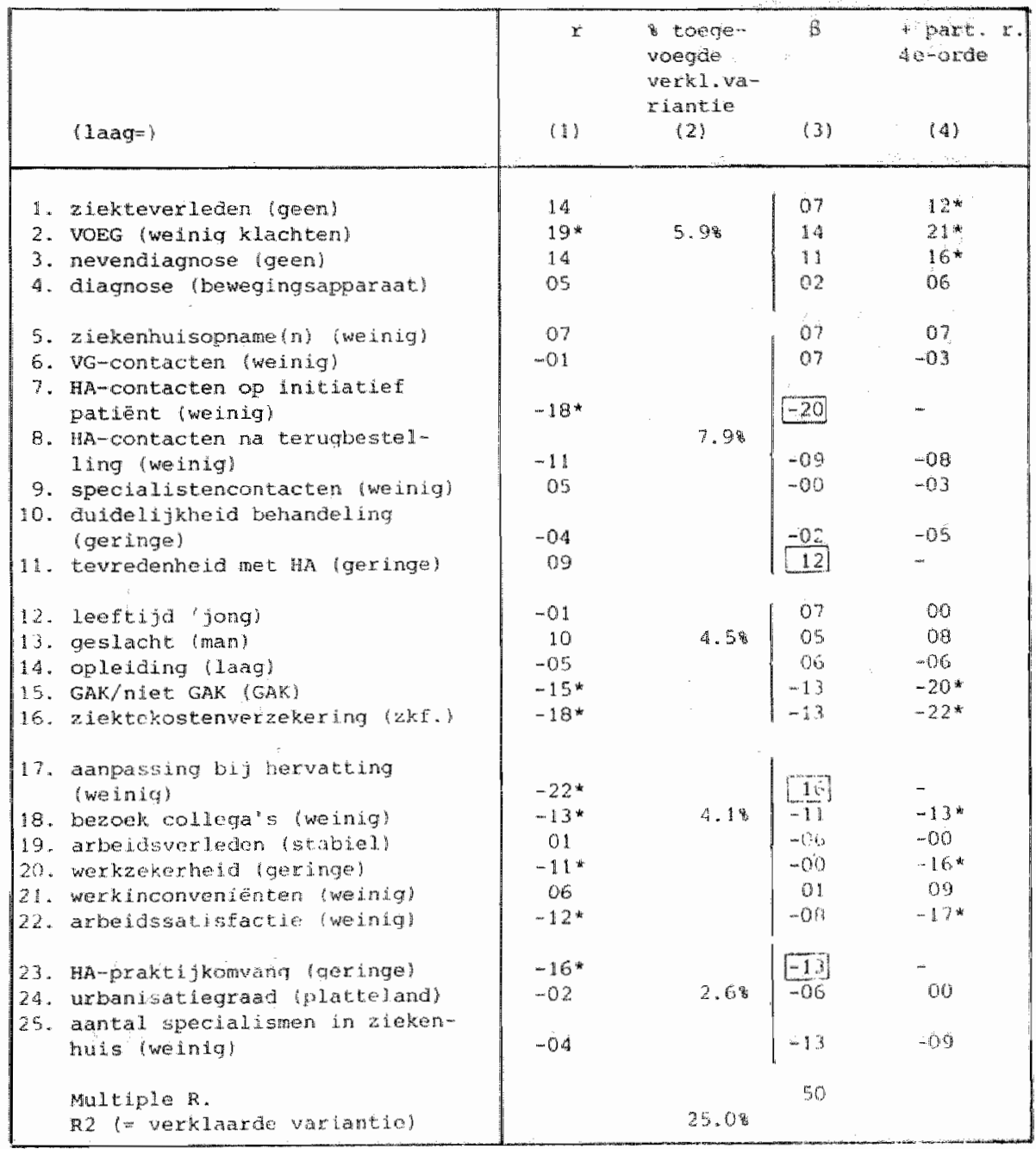

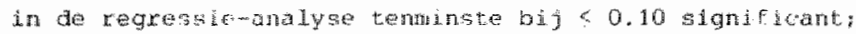

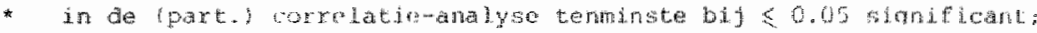

- hierbij zijn de warabelen $7,11,17$ en 23 constant genowan. 
Deze 7 verbanden, alsmede de vier oorspronkelijke significante relaties worden nu per rubriek toegelicht.

I. In de categorie der kenmexken van de aandoening is sprake van 3 significante verbanden: naarmate de respondenten meer klachten op de VOEG-lijst hebben aangegeven en wanneer zij één of meex neven- of combinatiediagnoses hebben, zijn zij langer ziek. Dit gegeven spoort met ander ziekteverzuim-onderzoek, waarin vastgesteld is, dat de aard van de aandoening van doorslaggevende betekenis is voor de duur van ziekteperioden (zhe hoofdstuk 2). ook het verband, waaruit blijkt, dat de ziekteduur langer is, naarmate de aandoening al een langer durend karakter heeft, komt overeen met ander onderzoek (de Jong e.a., 1981, Luyckx, 1982). Al met al blijkt uit de resultaten in deze rubriek eens te meer, dat het in dit type van medisch-sociologisch onderzoek onontbeeriljk is, on indicatoren van de (ernst van de) aandoening mee te nemen.

II. In de rubriek der kenmerken van de behandeling doen zich twee significante verbanden voor. Ten eerste zijn patiënten korter ziek, naarmate zij vakex contact met de huisarts hebben; dit geldt evenwel alleen voor contacter op initiatief van de patiënt. Dit resultaat kan op twee onderliggende mechanismen duiden. Aan de ene kant kan het erop wijzen, dat de lichtere aandoeningen, die kortere ziekteduren met zich meebrengen, vooral in de eerste lijn behandeld worden. Aan de andere kant is het niet ondenkbaar, dat de patiënten, die de werkhervatting willen bespoedigen, daarom uit eigen beweging vaker naar de huisarts gaan. Een tweede resultaat uit deze rubriek betreft het feit, dat men meer tevreden is over de huisarts, naarmate men langer ziek is. Hierin schullt wellicht de aanwijzing, dat de huisarts vooral bij de langerdurende ziektegevallen voor de patiënt een belangrijk steunpunt is.

III. Van de 5 patiëntenkenmerken blijken er slechts 2 significante verbanden met ziekteduur te vertonen. Dit impliceert allereerst, dat noch leeftijd en geslacht noch opleiding een significante bijdrage aan de verklaring van de ziekteduurverschillen leveren. Hiermee komt ons 
onderzoek overeen met de resultaten van wiersma (1979) en Merens-Riedstra (1981) in dit opzicht.

ofschoon leeftijd, geslacht en opleiding in bevolkingsof werknemerspopulaties geijkte kenmerken zijn om verschillen in ziekteverzuim te beschrijven, blijken zij in studies onder langdurig zieken als determinant van ziekteduren weg te vallen. Kennelijk beinvloeden deze persoons-kenmexken de kans op al dan niet ziek worden; dit hebben wij, voor wat betreft de opleiding, in hoofdstuk 7 al gezien en zullen wij ook aanstonds nog zien; maar als er eenmaal sprake is van een aandoening, zijn deze kenmerken niet meer rechtstreeks van invloed op de uiteindelijke ziekteduur. De directe inviloed, die deze kenmerken in bevolkingsstudies hebben, wordt in studies onder patiënten overgenomen door indicatoren van de (ernst van de) aandoening. Men vergelijke in dit verband een soortgelijke slotconclusie van v.d. Zee (1982) betreffende onderzoek naar medische consumptie.

Dit alles laat onverlet, dat er toch 2 significante verbanden in deze variabelenrubriek te signaleren zijn. zowel GAK- als ziekenfondsverzekerden hebben langere ziekteduren dan de respectievelijke andere categorieën respondenten. Zoals wij ook al in hoofdstuk 7 vastgesteld hebben, duiden beide verbanden op een bepaald type patiënten, te weten: langdurig zieke werknemers, die overwegend in het particuliere bedrijfsleven werkzaam zijn en gemiddeld geen bijzonder hoge inkomsten verwerven. Vrij duidelijk is hier sprake van invloeden, afkomstig uit de werksituatie van de patiënten.

Deze invloeden kunnen tot uiting komen in een verhoogde terugkeerdrempel voor deze werknemers; deze kan onder meer het gevolg zijn van ongunstiger arbeidsomstandigheden en geringere mogelijkheden tot aampassing bij de werkhervatting. Aan de andere kant is het niet bij voorbaat uit te sluiten, dat deze patiênten een hogere verzuimbehoefte hebben, en daardoor niet zo vaak uit eigen beweging hun hervatting bespoedigen. Ten derde is 
het mogelijk, dat juist deze werknemers gemiddeld exnstiger aandoeningen hebben, hetgeen dan via onze indicatoren van de aandoening vermoedelijk onvoldoende gemeten is.* Het waarschijnlijkst is dat deze drie factoren in combinatie werkzaam zijn.

IV. In totaal blijken 3 werkkenmerken significant met de ziekteduur samen te hangen. Ten eerste blijkt de ziekteperiode langer te duren, wanneer men hervat heeft met een of meer werkaanpassingen. Hier is geen sprake van een oorzaak van lange zlekteduren, maar van een gevolg. Werkaanpassingen zullen nameiljk vooral bij patiënten met meer exnstige aandoeningen noodzakelijk zijn, terwijl juist deze patiënten in het algemeen ook langer ziek zullen zijn.

Een tweede significant verband in deze rubriek geeft aan, dat men minder lang ziek is, wanneer men meer bezoek van collega"s en chef ontvangt. Dit verband blijkt een bevestiging te zijn van de betogen van Philipsen (1969a) en Ris (1978) in dit opzicht (zie ook de Jong e.a.. 1981). Zij hebben namelijk gesteld, dat contact met zieke werknemers vanuit het bedrijf of de inste1ling duurverkortend werkt. Op deze manier zou immers de binding van de zieken met de werkorganisatie intact blijven, hetgeen de reintegratie in het arbeidsproces zou versmellen.

Zoals gezegd, kan men het hier gevonden verband op deze wijze interpreteren. Anderzijds is het ook niet ondenkbaar, dat oorzaak en gevolg andersom liggen: juist patiënten, die kort ziek zijn, ontvangen veel bezoek; dat neemt echter in frequentie af, naarmate de ziekteperiode langer duurt en de patiënt de binding met zijn werk en collega's begint te verliezen. Waarschijnlijk heeft de gevonden relatie een cyclisch karakter en is

immers, indien een ernstiger ziekteaanbod bij GAK- en $\mathrm{ZF}$-verzekerden door ons adequat gemeten zou zijn en dit zou de enige achtergrond van de langere ziekteduren van GAK- en $Z F$-verzekerden zijn, dan zou het nu gevonden effect niet in onze analyse naar voren gekomen zijn. 
er sprake van een functioneel verband, dat roil zeggen een verband zonder duidelijke oorzaak en gevolg.

Tenslotte blijkt in deze rubriek, dat men langer zlek is, naamate men minder tevreden is met diverse aspecten van zijn werk. Dit gegeven siuit aan op het eerdex geconstateerde verband, dat een geringere arbeidssatisfactie bij patiënten lejat tot langere stuurloze perioden. Hiermee stelien wij in aansluiting op alle voorgaande onderzoek vast, dat mensen langer afwezig wegens ziekte zijn, wanneer de werksituatie voor hen meer te wensen over laat (zie ook hoofdstuk 2).

Dan is er nog een tweetal variabelen in deze rubriek, dat tegen andere bevindingen in geen effecten op ziekteduur sorteert. Zo blijkt er geen samenhang tussen werkinconveniënten en ziekteduur te zijn. De verklaring hiervoor, alsmede voor het nog vreemdere negatieve verband, dat de Jong e.a. (1981) in dit kader vinden, moet men zoeken in het zgn. "healthy worker-effect" (Olsen, 1981). Dit effect geeft weer, dat er ten aanzien van het werken onder slechte omstandigheden (zelf-) selectie optreedt: werknemers, die niet tegen inconveniënten bestand zijn, worden er bij voorbaat niet aan blootgesteld, stellen er zichzelf niet aan bloot, of verdwijnen sneller dan anderen uit zulke arbeidsomstandigheden.

Verder kummen wij ook geen verband constateren tussen werkzekerheid en ziekteduur, terwijl wiersma (1979) en de Jong c.s. (1981) zo'n relatie wel vinden. Meer precies geformuleerd is dit verband ex wel in de partiele correlatie-analyse, in de richting zoals die ook door andere onderzoekers is gevonden. Maar in de regressieanalyse is de relatie totaal afwezig; reden, warom wij de relatie in ons onderzoek als niet-bestaand beschouwen.

Een verklaring hiervoor kan men mogelijk vinden in de gedeeltelijk andere samenstelling van onze steekproef. Een gedeelte van onze steekproef bestaat immers uit werknemers uit de gezondheidszorg en ambtenaren; in leder geval ambtenaren komen in de beide andere onderzoeken niet voor. Tot 1982 speelde het thema van de werkzekerheid in gezondheldszorg- en overheidsinstel- 
1ingen nog zo goed als niet (zle voor opmerking met dezelfae strekking: Aarts e.a., 1982b). In statistische temen ultgedrukt: de variantie en daarmee het verklaringsvermogen van de variabele "werkzekerheid" is in ons onderzoek relatief geringer.

Hilermee siuiten wij de bespreking van de rubriek der werkkenmerken af.

v. Alvorens wij overgaan tot de vermelding van de significante verbanden wit het blok der indicatoren van het gezonahejaszorgaanbod, eerst een opmerking vooraf. In deze rubriek hebben wij de variabele "afstand woonplaats respondent tot ziekenhuis" vervangen door de urbanisatiegraad van die woonplaats. Dit hebben wij gedaan, omdat in het ziekteverzuimonderzoek de urbanisatiegraad een nogal prominente rol speelt (Philipsen, 1969a; Wiersma, 1979). Ten tweede konden wij dit veilig doen, omdat beide variabelen fors intercorreleren (zie hoofdstuk 6). Regresie-analyses, warin afwisselend een van deze twee variabelen zijn opgenomen, verschillen dan ook niet van elkaar.

Dan blijkt ook, dat noch de afstand tot het ziekenhuis noch de urbanisatiegraad enige invloed op de ziekteduur heeft. Zoals gezegd, wijkt dit af van ander ziekteverzuimonderzoek. De verklaring hiervoor is identiek aan hetgeen bij de analyse van het verwijscijfer vermeld is: in het dichtbevolkte z-Limburg biedt noch de afstand tot het ziekenhuis, noch de urbanisatiegraad veel variantie. Om de gedachten te bepalen: in ons onderzoeksbestand kan van de 40 gemeenten ex slechts 1 volgens CBS-criteria als plattelandsgemeente worden gekenmerkt.

Van de twee andere variabelen in deze rubriek blijkt er één wel significant te correleren met de ziekteduur. De ziekteduur is - ceteris paribus-gemiddeld korter, wanneer de gemidaelde hulsartsenpraktijkomvang per gemeente groter is. Dit verband is opvallend en druist tegen velex verwachtingen in, warounder die van Buijs (1982). Hij veronderstelt, dat het ter bekorting van de behandelingsduur (....) zeer belangrijk is, om te komen tot een praktijkverkleining voor huisartsen. Het zojuist gevonden verband lijkt deze veronderstelling aan te 
vechten. Met nadruk "lijkt", omdat ons datamateriaal in dit opzicht niet optimaal is, gelet op de twee analysenivo's, die in beide verbanden gehanteerd worden (resp. gemeente- en patiëntennivo; zie ook hoofdstuk 6).

Toch is het niet op zijn plaats, om al te pessimistisch over de kwaliteit van dit resultaat te zijn. Immers, ook met behulp van gegroepeerde gegevens kunnen wij het verband in zijn elementaire vorm laten zien. Hiextoe hebben wij de onafhankelijke variabele in 4 categorieën gesplitst, met daarin ongeveer even grote antallen respondenten. De respondenten uit Masstricht vormen hierbij één categorie. Vervolgens hebben wij per categorie de gemiddelde ziekteduur van de desbetreffende respondenten berekend en in grafiek 8.1 . weergegeven.

Grafiek 8.1 .

Relatie tussen HA-praktijkomvang in de gemeente van inwoning en ziekteduur, op basis van gegroepeerde data.

ziekteduur

in werkdagen

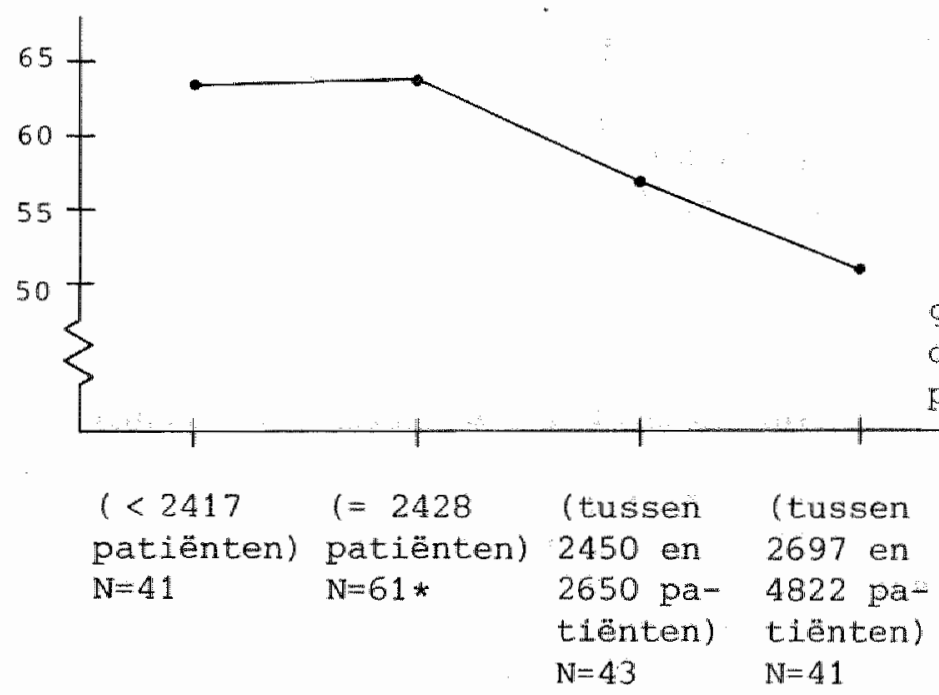

dit zijn alle respondenten uit Maastricht; het getal 2428 betreft de gemiddelde HA-praktijkomvang in Maastricht. 
Duidelijk is in deze grafiek een dalende lijn te zien. Deze lifn -gebaseerd op een zeer elementaire bivariate analyse van gegroepeerde data- geeft precies hetzelfde verband weer als uit de multivariate regressie-analyse met data op individueel nivo naar voren gekomen is. Dit geeft vertxouwen in de betrouwbarheld van het betreffende verband.

Niettemin is ex nog een punt, waarvoor wij moeten controleren, teneinde meer zekerheid over de juistheid van de verbanden te kxijgen.

Dit betreft de vraag, of de geconstateerde verbanden niet het gevolg zijn van een of ander (sub-) regionaal effect. Het is namelijk denkbaar, dat het grote aantal in Maastricht e.o. woonachtige respondenten (ca. $1 / 3$ gedeelte van de steekproef), een doorkruisende factor in dit verband is. Welnu, wanneer wij de multiple regressie-analyse opnieuw uitvoeren, maar dit keer na vervanging van de urbanisatiegraad door de dichotome variabele "Maastricht/niet-Maastricht", blijven de verbanden op precies dezelfde wijze gehandhaafd. Maar bovendien blijkt, dat de dichotoom "Maastricht/nietMaastricht" ook samenhang met de ziekteduur vertoont; de Mastrichtse respondenten zijn -ceteris paribusgemiddeld langer ziek. Aan de inhoudelijke betekenis van dit resultaat besteden wij geen verdere aandacht; het is immers onduldelijk, of hier sprake is van een of ander steekproefeffect dan wel van een adequate beschrijving van de werkelijkheid.

Blijft staan, dat ook uit deze analyse de aanwijzing naar voren komt, dat patien̈ten van huisartsen met grotere praktijken -ceteris paribus- relatief korter ziek zijn. Ter interpretatie van deze onverwachte uitkomst kan men een drietal redeneringen volgen. Een interpretatie zou kunnen zijn, dat huisartsen met gemiddeld grotere praktijken minder tijd per patiënt hebben " met als gevolg, dat zij minder geneigd zijn tot diepgaande diagnostiek en uitgebreide therapie. Volgens Boots (1983). van wie deze redenering afkomstig is, kan dit de verklaring zijn van zijn bevinding, dat bij gxotere praktijken minder verwijzingen per 100 consulten plaatsvinden. Ons inziens zou deze redenering ook van toepassing op de relatief kortere ziekteduren van patiënten van grotere praktijken kunnen zijn. 
Een alternatieve interpretatie in dit verband luidt als volgt: in kleinere praktijken hebben huisartsen mindex ervaring in het herkennen en behandelen van sommige ziekten (Hooymans, 1983); hierdoor kunnen zij wellicht minder snel tot beslissingen inzake behandeling en beëindiging van de ziekteperiode komen, dit in tegenstelling tot de huisartsen met grotere praktijken. Tenslotte is ex een derde verklaring, die zlch kan beroepen op plausibiliteit. Volgens deze verklaring geven artsen met gemiddeld grote praktijken er blijk van, een goede praktijk te kunnen voeren, bijvoorbeeld doox een goede "klinische blik" te hebben. zij zullen relatief vaak volgens het klassieke medische beginsel "in dubio abstine" werken. Met andere woorden, zij blijven niet doorbehandelen, wanneer de aandoening daar geen redelijk gegronde aanleiding toe geeft.

Bij deze interpretaties moeten wij evenwel nogmaals tot voorzichtigheid manen. zoals gezegd, is dit verband het resultaat van een twee-nivo's-analyse. De variabele "omvang huisartsenpraktijk" is -zoals ook vaker is gezegd- een gemiddelde waarde voor de gehele gemeente, waar de respondent in kwestie woonachtig is. Gegevens over ledere praktijk apart zouden daarentegen veel precieser zijn geweest en ons beduidend meer zekerheid over de juistheid van het verband hebben gegeven. Deze gegevens hebben wij helaas niet tot onze beschikking. Daarom is het noodzakelijk, dit resultaat aangaande de omvang van de huisartsenpraktijk onder voorbehoud te presenteren.

8.3. De aanvullende partiële correlatie-analyse

Dan vervolgen wij nu onze analyse volgens de inmiddels gebruikelijk geworden procedure: namelijk met partiẻle-correlaties op basis van de significante resultaten uit de voorgaande analyses.

Terwille van de overzichtelijkheid hebben wij echter niet alle significant correlerende onafhankelijke vaxiabelen bij de berekeningen opgenomen. Van de kenmerken van de aandoening hebben wij alleen de VOEG opgenomen. Deze variabele is 
central genoeg, on ook de andere kenmerken van de aandoening te representeren (zie hoofdstuk 6). Verder hebben wij de variabele "aanpassingen bij werklervatting" buiten beschouwing gelaten: deze variabele is immers een gevolg en geen corzaak van lange ziekteduren. Tenslotte hebben wij alleen de variabele met betrekking tot de ziektekostenverzekering opgenomen; vanwege de hoge intercorrelatie met de variabele "loondervingsregeling" is het opnemen van éen van belde variabelen hier voldoende.

Met de 7 resterende significante onafhankelijke variabelen is de partiële correlatie-analyse uitgevoerd. Maar daarnaast is in deze analyse nog 1 andere onafhankelijke variabele opgenomen; te weten de opleiding van de de respondenten. Deze extra variabele voeren wij in vanwege zijn basale betekenis voor het optreden van ziekte.

Al met al zijn in deze aanvullende partiële correlatie-analyse, inclusief de afhankelijke, 9 variabelen betrokken. Dit impliceert dat de partiële-correlatie coëfficiënten van de $7 e-$ en 6e-orde zijn. Hiermee bereiken wij, dat wij de zuivere verbanden tussen telkens twee variabelen berekenen, waarbij de effekten van andere variabelen -hoe klein ook-uitgeschakeld zijn. 


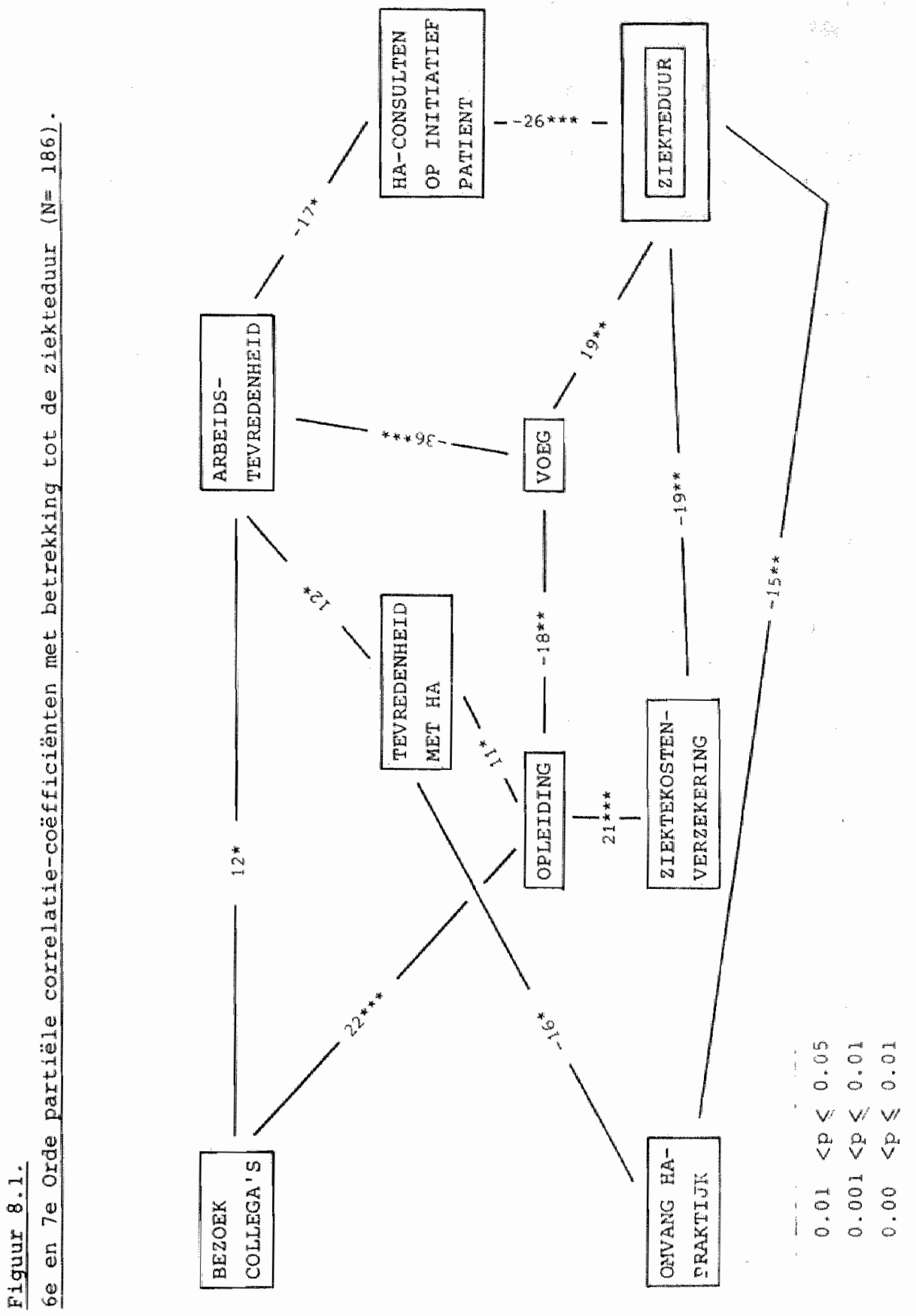


In figuur 8.1. zijn de resultaten van de analyse grafisch weergegeven. Het gaat hierbij alleen on variabelen, die tenminste significant zijn bij $p \leqslant 0.05$.

De eerste conclusie naar aanleiding van figuur 8. 1. houdt in, dat drie in de eerder analyses significant gebleken verbanden in deze nieuwe analyse wegvallen. Dit geldt voor de relatie tussen ziekteduur enerzijds en bezoek van collega's, tevredenheid met de huisarts en arbeidssatisfactie anderzijds. Deze verbanden -ontstaan door controle voor zeven variabelen- overschrijden hier slechts de $10 \%$ significantie-drempel. In deze analyse zijn op 5\%-nivo vier variabelen op de reeds bekende wijze gerelateerd aan de ziekteduur; dit geldt voor de variabelen: VOEG, aantal huisartsconsulten op initiatief van patiënt, ziektekostenverzekering en omvang van de huisartsenpraktijk.

Naar aanleiding van de relaties met de ziekteduur is nog een aantal opmerkingen te maken:

- arbeidstevredenheld is niet gecorreleerd met de ziekteduux in deze analyse; niettemin blijft deze variabele een rol spelen, omdat patiënten met een geringere arbeidstevredenheid hoger scoren op de VOEG-lijst en een hogere VOEG-score op zijn beurt weer tot langere ziekteduren leidt.

- verder blijkt uit figuur 8.1. opnieuw, dat patiënten van huisartsen met grotere praktijken relatief korter ziek zijn; deze patiënten zijn evenwel ook minder tevreden over hun huisarts.

Beide verbanden komen consistent bij elkaar in het gegeven, dat patiënten meer tevreden zijn over hun huisarts, naarmate zij langer ziek zijn (zie de regressie-analyse; in de partiële correlatie-analyse bedraagt deze coëfficiënt $.11, p=0.06$ ). In schema ziet dit er als volgt uit.

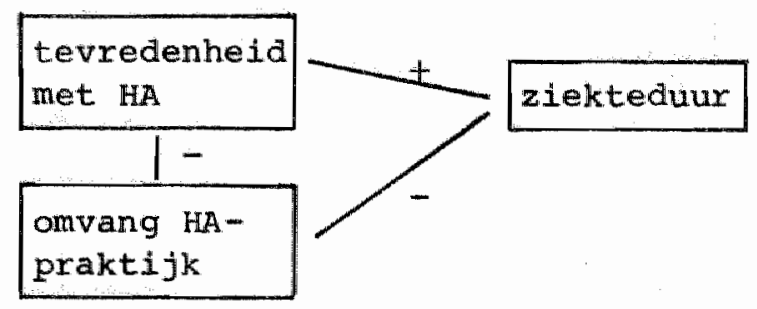


Een interpretatie van deze verbanden zou kunnen zijjn, dat patiënten meer tevreden over hun huisarts zijn, wanneer zij van hem of haar meer aandacht en legitimatie voor hun afwezigheid wegens ziekte krijgen. Door huisartsen met grotere praktijken wordt aan deze verwachting vanwege tijdgebrek (Boots, 1983) of een meer traditionele klinische houding wellicht minder voldaan. Dit leidt er dan toe, dat patiënten van grotere praktijken relatief korter ziek, maar tegelijkertijd ook mindex tevreden zijn.

Overigens blijft ook voor deze interpretatie het voorbehoud gelden, dat wij eerder al hebben uitgesproken over de waarde van de variabele "HA-praktijk-omvang".

Dan doet zich in figuur 8.1. nog een antal andere - in hoofdstuk 7 voor een deel al geconstateerde- verbanden voor. Naarmate patiënten een lagere opleiding achter de rug hebben, scoren zij hogex op de VOEG-lijst en zijn zij vaker ziekenfondsverzekerd. Beide verbanden hebben wij reeds in hoofdstuk 7 gezien en toegelicht. Verder blijkt dat de hoger opgeleide respondenten gemiddeld genomen meer tevreden zijn over hun huisarts; bovendien zijn degenen die meer tevreden zijn over hun huisarts, ook meer tevreden over hun werk. Tenslotte krijgen zowel de hoger opgelelde respondenten als de respondenten, die meer tevreden over hun werk zijn, vaker bezoek van hun collega's. Dit wijst op een grotere binding van deze respondenten met hun werk.

Tot zover de bespreking van de analyses met betrekking tot de ziekteduur.

\subsection{Samenvatting}

In dit hoofdstuk is de ziekteduur onder de Ioupe genomen. Hiermee sluit dit hoofdstuk aan op enkele andere Nederlandse studies naar langdurig ziekteverzuim. Voor een deel komen onze resultaten overeen met die andere ondexzoeken, terwijl voor een deel ook geheel nieuwe informatie op dit terrein is opgedaan. Ondubbelzinnig is via regressie-analyse aangetoond, dat die patiënten ceteris-paribus langer ziek zijn, die minder vaak uit eigen beweging naar de huisarts gaan en het werk met meer aanpassingen hervatten. Verder is geble- 
ken, dat men bij langere ziekteduren meer tevreden over de HiA is.

Voorts is er nog een aantal zwakkere verbanden gesignaleerd:

- wanneer er sprake is van hoge voEG-score, de aanwezigheid van een combinatiediagnose en een meer chronisch karakter van de aandoening, is de ziekteduur ook relatief langer;

- GAK- en ZF-verzekerden, dat wil zeggen werknemers in het particuliere bedrijfsleven met relatief lagere inkomens, zijn langer ziek dan anders verzekerden, i.e. vooral werknemers bij de overheid of in de gezondheidszorg:

- wanneex men zich meer ontevreden over zijn werksituatie toont, is men langer ziek; langere ziekteduren gaan bovendien samen met minder bezoek van collega"s en/of chef.

over de effecten van het gezondheidszorgaanbod op ziekteduren is op grond van ons datamateriaal niets met 100 s zekerheid te zeggen. Niettemin is er een aanwijzing, dat patiënten -ceteris paribus- korter ziek zijn, wanneer hun huisarts een grotere praktijk heeft. veronderstellingen omtrent de achtergrond van deze opvallende bevinding omtrent huisartsen met grotere praktijken kan men enerzijds zoeken in hun wellicht grotere werkervaring en anderzijds in hun geringere neiging tat medicaliseren en grotere tijdsdruk. 
HOOFSTUK 9

SAMENVATTING EN BESPREKING VAN DE RESULTATEN.

\subsection{Samenvatting in grate lijnen.}

Het hier beschreven onderzoek is opgezet vanuit de gedachte, dat vertraging tijdens de behandeling van patiënten verzuimduurverlengend zou zijn. In $z$-Limburg-de regio, watin dit onderzoek is uitgevoerd- zouden $\mathrm{zgn}$. wachttijden tijdens de behandeling een nog omvangrijkere betekenis hebben dan elders in Nederland.

Als onderdeel van een groter $z$-Limburgs ziekteverzuimproject is het onderzoek opgezet, om deze gedachte te toetsen en nader uit te werken. Hiertoe zijn ruim 200 werknemers, die tenminste 4 weken aaneengesloten afwezig wegens ziekte waren, als respondenten bij het onderzoek betrokken.

Van hen zijn gegevens verzameld over hun personalia, aandoening, werk, eventuele werkhervatting en over de wijze, waarop zij als patiënten behandeld zijn. Zo is onder meer van elk contact, dat de respondenten met vertegerwoordigers van de gezondheidszorg gehad hebben, een tiental kenmerken geregistreerd; hiertoe behoorden de exacte datum van het contact, het type hulpverlener en de initiator van het contact. De registratie besloeg de periode vanaf datum ziekmelding tot werkhervatting, WAO/IP-intrede of een andere vorm van uittrede uit het arbeidsproces.

De deelname door langdurig zleke werknemers aan het ondexzoek verliep dermate gunstig, dat de uiteindelijke steekproef zich op belangrijke kenmerken als leeftija en geslacht niet significant onderscheidt van de weigeraars. De steekproef kon derhalve als voldoende representatief voor de $z$ Limburgse populatie beschouwd worden. De onderzoeksresultaten zijn evenwel alleen van betekenis voor de situatie in geheel Nederland, voorzover het de verklarende analyses betreft.

Een eerste doelstelling van het onderzoek was gericht op het beschrijven van de wachttijden, die z-Limburgse patiënten tijdens hun behandeling meemaken. Deze $z$-Limburgse wachttijden konden vergeleken worden met soortgelijke gegevens uit 
de Randstad in 1974/75. Uit deze vergelijking kwam naar voren. dat het voor leeftijd gecorrigeerde netto percentage wachttijd in Z-Limburg (1981) 2.68 hoger is dan in de Randstad (1974/75). In totaal bedragen de $z$-Iimburgse wachtdagen 22. 19. van alle door langdurig zieke werknemers verzuimde wexkdagen. Met name concentreren de $\mathrm{z}$-Limburgse wachtdagen zich rondom ziekenhuisopnamen en de zgn. stuurloze perioden: in deze lateste perioden wordt geen (verdere) koers voor behandeling uitgezet. Het eerstgenoemde probleem hangt vermoedeijk samen met de hogere opname-coëficient in $z$-Limburg, het tweede nogelifk met de minder direct sturende z-Iumburgse (GAK-) VG-en.

Evenals in de Randstad blijken de Z-Limburgse verwijzingen naar orthopaeden en rheumatologen het langst van alle verwijingen nat specialisten te duren. Verder blijken -ook weer overeenkomstig de situatie in de Randstad- de latere niet-hervatters in vrijwel alle opzichten meer wachttijden mee te maken dan de hervatters. Tenslotte is de indruk ontstaan, dat VG-en in hun verzuimbegeleiding nogal gedifferentieerd te werk gaan, afhankelijk van de organisatorische context, warin zij werkzaam zijn. zo zijn er verschilien geconstateerd in de frequentie, waarmee vG-en contact met hum verzekerden hebben, alsmede in de wijze warop vervolgcontacten tot stand komen.

Aan het einde van de registratieperiode heeft 87 van de respondenten het werk weer volledig of gedeeltelijk hervat. Ruim $1 / 3$ gedeelte van alle respondenten heeft op enig moment tijdens de ziekteperiode gesproken over mogelijkheden, om angepaste arbeid te verkrijgen. Behalve met de familie hebben deze respondenten hierover meestal met de VG of $B A$ gesproken. Uitelndelijk hebben 39 respondenten $(=24 \%$ ) het werk hervat met een of ander-definitieve of tijdelijke-werkaanpassing. Doorgaans betrof dit een tijdelijke verandering van de werktijafactor. overigens is een kwart van alle werkhervattingen om ulteenlopende redenen niet tot volle tevredenheid van de werknemers verlopen.

Van de 24 niet-hervatters tenslotte gaven 10 respondenten te kennen, dat zij -ofschoon arbeidsongeschikt verklaard- wel tot werken in stalt waren.

Het tweede gedeelte van de onderzoeksresultaten betrof de verschillen tussen patiënten in wachtdagen en ziekteduren. 
De wachtdagen zijn hierbij in twee typen onderscheiden, $t . w$. in verwijzingswachtdagen en stuurloze perioden. Om na te gaan, welke respondenten verwijzingswachtdagen hebben kunnen meemaken, is voorts bestudeerd, welke factoren leiden tot een grotere kans op verwijzing naar specialistische zorg. Achtereenvolgens hebben deze analyses de volgende inzichten opgeleverd.

Patiënten hebben een grotere kans op verwijzing naar specialistische zorg, wanneer het aantal specialismen in het meest nabije ziekenhuis groter is, en de behandeling in het begin van de ziekteperiode als onduidelijker wordt ervaren. verder hebben ook patiënten met een grotere arbeidssatisfactie en een stabieler arbeidsverleden een grotere kans op verwijzing; dit laatste geeft vermoedelijk aan, dat deze zieke werknemers relatief meer objectieve aandoeningen hebben.

Het aantal verwijzingswachtdagen van doorverwezen patiënten is uitsluitend en alleen gerelateerd aan de urgentie van hun klachten. Alleen patiënten, die voor dezelfde aandoening al eerder verzuimd of een arts geraadpleegd hebben, maken relatief meer verwijzingswachtdagen mee; dit in tegenstelling tot patiënten met acuut ontstane klachten, zoals bij ongevallen.

Stuurloze dagen, d.w.z. dagen zonder dat er een koers voor verdere behandeling is uitgezet, komen vooral voor bij zieke werknemers, die een aandoening zonder verleden hebben, en/of een aandoening die wijst op een algemene lichamelijke malaise-toestand en niet zozeer op een specifieke beperking van het bewegingsapparaat. Verder maken vooral ziekenfondsverzekerden en zieke werknemers met een geringe arbeldssatisfactie relatief veel stuurloze dagen mee.

De laatste analyse betreft de verschilien tussen patiënten in lange ziekteduren. ziekteduren zijn relatief langer, wanneer patiënten hoger op de VOEG scoren, een combinatiediagnose hebben en/of een aandoening met een meer chronisch karakter. Iangere ziekteduren komen verder vaker voor biji patiënten, die bij het GAK en ziekenfonds verzekerd zijin, dat wil zeggen bij patiënten met lagere inkomens, werkzaam in het particuliere bedrijfsleven. Verder maken patiënten langere ziekteduren mee, wanneer zij meer ontevreden over hun werksituatie zijn en minder bezoek van collega's e.d. tijdens hun ziekteperiode ontvangen. Ook patiënten, die het werk met een of meer aanpassingen hervatten, zijn relatief 
langer ziek. Tenslotte zijn patiënten relatief langer ziek, wanneer zij minder vaak uit eigen beweging naar de huisarts gaan, wanneer de praktijk van hun huisarts relatief kleiner is en wanneer men meer tevreden over de hulsarts is.

9.2. Beperkingen van het onderzoek; voorstellen voor verder onderzoek.

Zoals vakex bij onderzoek naar langdurig ziekteverzuim of de gezondheidszorg ( $\mathrm{b} . \mathrm{v}$. Boots, 1983), heeft deze studie naast "harde" bewijzen ook stof tot discussie opgeleverd. De reden hiervan is, dat vrijwel elk onderzoek van dit type tevens een nieuw nog weinig geëxploreerd terrein bestrijkt. Van werkelijke replicaties is zelden of nooit sprake.

Voor wat het beschrijven van de wachttijden betreft, konden wij gebruik maken van een reeds eerder ontwikkelde onderzoeksmethodiek. De verklarende analyses uit het tweede gedeelte zijn daarentegen volledig nieuw. Gegeven die situatie hebben wij zo veel mogelijk relevant lijkende variabelen bij deze analyses willen betrekken; vandaar dat deze analyses als het ware de indruk van schoten hagel maken: een relatief groot doel wordt slechts aan de oppervlakte getroffen. Hiermee is een duidelijke beperking van het onderzoek gekenschetst.

Vervolgonderzoek met een soortgelijke vraagstelling als het onderhavige zou daarom specifieker moeten zijn, zowel qua opzet als probleemstelling. Een manier, om zulks te doen, zou kunnen bestaan uit wat Mootz (1981) het homogeniseren van de verzuimnoodzaak noemt. Met andere woorden, niet alle mogelijke diagnoses zouden -althans in het verklarendonderzoek opgenomen moeten worden, maar slechts een zeer beperkt aantal.

Op deze wijze krijgt men groepen van patiënten in het onderzoek, die op grond van hun aandoening min of meer dezelfde behandelingswijzen zouden moeten volgen. Is er dan toch sprake van sterke verschilien in behandelingskenmerken, dan zijn deze expliciet het gevolg van andere factoren dan de aard van de aandoening. Een dergelijke onderzoeksopzet verhoogt de duidelijkheid van de bevindingen. Dat wij deze aanpak niet gevolgd hebben, vloeit voort uit het feit, dat wij voor het beschrijvende gedeelte juist zoveel mogelijk diag- 
nosecategorieën in het onderzoek moesten betrekken. Een andere beperking van het onderzoek heeft betrekking op het geografisch gezien kleine onderzoeksgebied. De beschrijving van de wachttijden heeft daarom slechts betekenis voor een klein stukje Nederland, te weten het Herstructureringsgebied $\mathrm{Z}$-Limburg. Vermoedelijk ook vanwege de beperkte omvang van het onderzoeksgebied zijn de variabelen met betrekking tot het gezondheidszorgaambod niet echt goed uit de verf gekomen. Men zou daarom wensen, dat vervolgonderzoek op dit terrein beter verspreid over Nederland zou plaatsvinden. Is men geinteresseerd in de effecten van verschillende sociale zekerheids- en gezondheidszorgstelsels, dan zou zelfs vervolgonderzoek in verschillende landen niet onwenselijk zijn (Andriessen, Holthuis en Prins, 1983).

Een laatste beperking van het onderzoek geldt het feit, dat slechts gebruik is gemaakt van informatie van de kant van patiënten. Deze eenzijdigheid maakt ten eerste, dat de logica van handelingen van artsen op die manier niet helder wordt. Ten tweede doen zich tijdens de behandeling van patiënten gebeurtenissen voor, die expliciet buiten het gezichtsveld van patiënten vallen. Te denken valt hierbij aan intercollegiaal overleg van artsen.

Vervolgonderzoek op het vlak van de patiënt-gezondheidszorginteractie zou derhalve ook van het gezichtspunt van artsen moeten uitgaan. Het probleem hierbij is, dat de gemiddelde langdurig zieke met diverse artsen tijdens een ziekteperiode te maken krijgt; dataverzameling bij al deze artsen is bijzonder moeilijk.

Een alternatief is dan, om de dataverzameling bij één type arts (HA, VG, BA e.d.) te laten plaatsvinden. Te denken valt hierbij aan vervolgonderzoek onder VG-en. De VG vormt immers ten eerste de centrale figuur, als het gaat om de beoordeling van de rechtmatigheid van de afwezigheid wegens ziekte. Ten tweede is het handelen van VG-en zeer zelden onderzocht, veel minder vaak dan het functioneren van curatief werkende artsen. Ten derde zijn er aanwijzingen -o.a. op grond van deze studie-, dat VG-en sterk gedifferentieerd opereren, al naar gelang de organisatorische context, waarin zij werkzaam zijn. Met het oog op het grote matschappelijke belang, dat aan deze kwestie verbonden is, dient via systematisch vervolgonderzoek duidelijkheid over deze aanwijzingen te komen. 
9.3. Beleldsoverwegingen naar aanleiding van het onderzoek.

Zoals in het begin van dit onderzoeksverslag duidelijk is geworden, heeft een beleldsvraag van de kant van de overheid ten grondslag gelegen aan deze studie. Deze beleidsuraag had betrekking op de problematiek van het langdurig ziekteverzuim. Gelet op de invalshoek, die in deze studie gekozen is, is echter ook een andere problematiek aan de orde gesteld, te weten de structuur en het functioneren van de gezondheidszorg. Dit onderzoek biedt derhalve de mogelijkheid, om beide vormen van beleidsproblemen op elkaar te betrekken; dit is iets, wal met nadruk door Van den Bosch en Petersen (1982) om gevraagd wordt.

zaj suggereren in dit verband, dat met name een uitbreiding van kosten voor preventieve gezondheldszorg een beperkend effect op langdurig ziekteverzuim zal hebben. Uitbreiding van de toch al absoluut en relatief zeer dure curatieve gezondheldszorg ( $\mathrm{vgl}$. ook van Etten \& Rutten, 1982) biedt volgens hen in dit verband geen enkel soulaas. In concreto bepleiten zij een uitbreiding van de bedrijfsgeneeskundige preventieve zorg; de daaraan verbonden kosten zouden via een daardoor te verwachten daling van het ziekteverzuim snel terugverdiend zijn.

Nu zijn de aannames, waarop zij deze verwachting stoelen, op goede gronden bekritiseerd (Nijhuls, Schröer en Soeters, 1983); hiermee is hun voorstel vrij kwetsbaar geworden. Nietternin is hun uitgangsgedachte -de koppeling van grezondheidszorg- aan ziekteverzuimproblematiek alsmede het relateren van de beide geldstromen- niet onaantrekkelijk. Wij willen de gedachte hier dan ook enigszins verder uitwerken, mede aan de hand van resultaten van ons ondexzoek. Wij geven hierbij een drietal overwegingen, die gericht zijn op evenveel knelpunten in de gezondheidszorg in verband met het ontstaan van wachttijden. Tot besluit berekenen wij de invloed van het wachttijdenprobleem op het totale ziekteverzuim in z-Limburg.

a. In hoofdstuk 2 hebben wij gesteld, dat verwijzingswachtdagen het gevolg zijn van een per regio en per specialisme ongelijk ontwikkeld aanbod van gezondheidszorgvoorzieningen. Een goed voorbeeld hiervan hebben wij zowel in de Randstad-als in de z-Limburgse studie kunnnen 
zien: de langste wachttijden betreffen de verwijzingen naar orthopaeden en rheumatologen (zie ook Tordoir e.a.. 1978; Buys, 1982)*. Kennelijk is het zo, dat het grote aanbod van aandoeningen aan het bewegingsapparaat (in ons onderzoek meer dan $30 \%$ van alle gevallen) niet in voldoende mate opgevangen kan worden door de bestaande personeelscapaciteit op het gebied van orthopaedie en rheumatologie.

Een kleine berekening kan dit verduidelijken. Indien in onze steekproef de aanvragen voor (poli-)klinische behandeling door orthopaeden en rheumatologen even snel verwerkt zouden zijn als door de algemeen chirurgen, zou het ziekteverzuim in onze steekproef 1.78 lagex zijn geweest (d.i. 285 werkdagen voor de gehele steekproef). Deze gegevens doen de vraag rijzen, wat hiervan de oorzaak zou kunnen zijn. Nader onderzoek zou moeten uitwijzen, of een verbetering in dit opzicht gerealiseerd zou kunnen worden via een verhoging van hetzij de personeels- en middelencapaciteit, hetzij van de efficiëntie van dit specialisme, dan wel van beiden.

Dan is ex een soortgelijk punt. De wachttijd voor ziekenhuisopname bedraagt in onze steekproef 38 van het totale verzuim. Of men dit veel vindt of niet, is nu niet de belangrijkste vraag. Er zijn evenwel op dit moment ontwikkelingen in gang gezet, die gericht zijn op een reductie van het aantal ziekenhuisbedden. Het gevaar van een dergelijke reductie kan echter zijn, dat deze -zonder correspondexende verlaging van de opnamecoëfficiënt of verkorting van de gemiddelde opnameduur -tot verlenging van de wachttijd voor opname kan leiden. Bij deze beleidsmatregel lijkt het daarom verstandig, de suggestie van V.d. Bosch en Petersen (1982) op te volgen. Dit is het verrichten van kosten-baten-analyses, waarbij zowel gelden voor gezondheldszorg als gelden voor loondervingsregelingen met elkaar in verband worden gebracht.

N.B.: dit betreft het tijdsverloop tussen de datum, warop de afspraak gemaakt is en de datum van het afgesproken contact. 
b. Gemiddelde verwijzingswachttijden kan men op twee manieren verkorten. Ten eerste kan dit door de wachttijd van elke verwijzing apart te verkorten; dit kan onder meer door vergroting - of tenminste geen verkleining- van de capaciteit van onderdelen in het tweede of derde echelon (zie punt a). Via een aanvullende aanpak kan men evenwel ook proberen het aantal verwijzingen te verkleinen. Hier betreden wij het terrein van het geneeskundig beslissingsproces. Bovendien raken wij hier aan de kwestie van de vexsterking van de eerste lijn. Met betrekking tot belde onderwerpen worden veel voorstellen gedaan, onder meer door Greep (1983a). Deze bepleit 0.a. de ontwikkeling van protocollaire geneeskunde, waarmee de interarts-variabiliteit onder meer ook ten aanzien van het aantal verwijzingen verminderd zou kunnmen worden (vgl. ook: Rutten, 1983). Bovendien toont hij zich een voorstander van een verbetering van de huisartsenspecialisatie. In aansluiting hierop wijst ook Streng (1983) op manco's in de geneeskundige opleidingen met name op het vlak van sociaal-geneeskundige aspecten. Hiernaast worden veel andere ideëen geopperd, die gericht zijn op versterking van de eerste lijn (diagnostische centra, groepspraktijken e.di). Te midden van deze discussie zouden wij één kwestie op grond van ons onderzoek willen benadrukken.

Blijkens ons onderzoek, is bij patiënten met psychische aandoeningen vrij vaak en langdurig sprake van stuurloze perioden; met andere woorden, zij ontvangen dan geen aanwijzingen vanuit de gezondheidszorg. Mogelijk is de curatieve (eerste-lijns) alsmede bedrijfs- en verzekeringsgeneeskunälge zorg nog te zeer alleen geëquipeerd voor somatische aandoeningen en te weinig voor psychische aandoeningen met de daaraan gekoppelde sociale problematiek. Gelet op de omvang en groei van het aanbod van psychische aandoeningen, lijkt versterking en verbetering van de eerste lijns-zorg ook in dit opzicht dringend gewenst.

c. Als derde basisprobleem in de gezondheidszorg is gewezen op de vaak gebrekkige informatie-overdracht van de behandelende naar de bedrijfs- en verzekeringsgeneeskundige sector (zie hoofdstuk 2). Mede als gevolg hiervan kan er een caesuur in de behandeling en begeleiding van zie- 
ke werknemers ontstaan, de zgn. stuurloze perioden. Met name ook in. z-Limburg vormen deze stuurloze dagen een relatief omvangrijk onderdeel van langdurige ziekteperioden.

In verband hiermee is de recente adviesaanvrage van de regering inzake sociaal-medische begeleiding bij ziekteen arbeidsongeschiktheidsregelingen van bijzondere betekenis. In deze adviesaanvrage (de Graaf, Kappeyne vaf de Copello, van der Reyden, 1983) worden drie alternatieven aangeboden, om manco's en knelpunten in de samenwerking van de sectoren op te heffen. Deze worden respectievelijk aangeduid als het "huisarts model", het "VG-model" en het "bedrijfsgezondheidskundig model".

In het "huisarts-model" wordt zowel de coördinatie van het behandelingsproces als de coördinatie van de werkhervatting in handen van de huisarts gelegd. In het "VGmodel" vormt de VG de centrale figuur bij de coördinatie van zowel behandeling als werkhervatting. Dat is ook het geval in het laatstgenoemde model, maar vG-en werken dan in een gezamelijke dienst met bearijfsartsen; deze laatste beperken zich tot de beoordeling van de arbeidsongeschiktheid en aanpassing van de werkplek vanuit een bedrijfsgeneeskundige visie; zij adviseren in dit opzicht aan de VG-sector.

Welke van de genoemde modellen het meest eenvoudig realiseerbaar en effektief is, valt op deze plaats niet uit te maken. Wel onderstreept ons onderzoek eens te meer de noodzaak, om via deze of andere beleidsmaatregelen wijzigingen in de bestaande sociaal-medische begeleiding van langdurig zieke werknemers aan te brengen.

d. Een laatste punt dat wij willen aansnijden, betreft het effect van de omvang van het wachttijdenprobleem op het totale ziekteverzuim in z-Limburg. Uitgangspunt van het onderzoek was immers de veronderstelling, dat wachttijden éen van de oorzaken van de langere ziekteduren in z-Limburg zouden zijn. Vastgesteld is nu, dat de wachttijden van de GAK-ziektegevallen -langer dan 6 weken- in $z$-Limburg 22.18 bearagen; dit is 2.68 meer dan in de Randstad in 1974/75. De vraag is nu, welk effect een vermindering van het percentage wachttijd met 2.68 op de gemiddelde ziekteduur in z-Limburg zou hebben.

Deze vraag laat $z i c h$ niet met zekerheid beantwoorden, 
omdat voor deze berekening niet alle gegevens bekend zijn. Toch kan men op basis van een arietal in redelijkheid te verdedigen aannamen een schatting van dit effect becijferen. Deze drie aannamen zijn in detail gespecificeerd in het eerste verslag van dit onderzoek, dat verschenen is onder de titel "Na de ziekmelding ......". Hiervoor zij daarom naar deze publicatie verwezen.

Uitgaande van deze drie aannamen hebben wij berekend, hoe sterk de gemidalelde ziekteduur in Z-Limburg zou zakken, wanneer het percentage wachttijd met $2.6 \%$ zou dalen (i.e. tot het nivo van de Randstad in 1974/75). Omdat evenwel het Randstad-percentage ook geen absolute norm is, hebben wij ook varianten becijferd, warin het wachttijapercentage zou dalen tot resp. $17.5 \%, 15.0 \%$ en 12.5\% (zie tabel 9.1.). Lagere varianten hebben wij niet berekend, omdat wij van mening zijn, dat het wachttijdprobleem wel verbeterd, maar noolt volledig uit de wereld geholpen zal kunnen worden.

Tabel $9.1 .:$

Effect van vermindering van het percentage wachttija op het ziekteverzuim in z-Limburg.

\begin{tabular}{|c|c|c|c|}
\hline \multirow{2}{*}{$\begin{array}{l}\text { vermindering van het } \\
\text { percentage wachttija } \\
\text { met: }\end{array}$} & \multirow{2}{*}{$\begin{array}{l}\text { daling van } \\
\text { de gemida } \\
\text { dur per } \\
\text { geval in } \\
\text { werkdagen }\end{array}$} & \multicolumn{2}{|c|}{$\begin{array}{l}\text { daling } v \cdot d \text {. gemiddelde } \\
\text { ziektedur per manjaar }\end{array}$} \\
\hline & & $\begin{array}{l}\text { in werk- } \\
\text { dagen }\end{array}$ & $\begin{array}{l}\text { In kalen- } \\
\text { dexdagen }\end{array}$ \\
\hline $2.58(\operatorname{tot} 19.5 \%)$ & 0.4 dagen & 0.8 dagen & 1.1 dagen \\
\hline 17.58$)$ & dagen & 1.2 dagen & 1.7 aagen \\
\hline 15.00$)$ & dagen & 2.0 dagen & 2.8 dagen \\
\hline 12.58$)$ & dagen & 2.8 dagen & 3.9 dagen \\
\hline
\end{tabular}

* verkregen via vermeniguuldiging met een factor 2; dit is de gemiddelde ziektefrequentie in $\mathrm{z}$-Limburg in 1979/80 (bron: Nijhuly en Soeters, 1982).

Deze berekeningen later onder meer zien, dat het terugbrengen van het percentage wachttijd tot het nivo van de Randstad (1974/75) per gewerkt manjaar een verzuimduurverkorting van gemiddeld 0.8 werkdag op zou leveren. Omgerekend voor een effectief werkjaar van 230 werkdagen, 
bedraagt deze bescheiden beperking van het wachttijdenprobleem 0.35 van de arbeidskosten. De verkorting van de verzuimduur per manjaar kan oplopen tot 2.8 werkdagen ( 1.28 van de arbeidskosten), wanneer men het percentage wachttijd tot $12.5 \%$ zou kunnen terugdringen. Overigens moet men zich realiseren, dat deze getallen gemiddelden zijn; dit impliceert, dat de hier berekende effecten voor sommige bedrijven en instellingen veel groter zullen zijn en voor andere veel kleiner.

Tenslotte $z i j$ er nogmaals op gewezen, dat de gemaakte berekeningen gebaseerd zijn op een drietal overigens in redelijkheid te verdedigen aannamen; deze omstandigheld geeft de uitkomsten meer een voorbeeldfunctie dan de status van een definitief eindcijfer. Hoe de exacte hoogte van de uitkomsten evenwel ook is, zeker is, dat het terugdringen van het percentage wachttijd verkorting van de gemiddelde verzuimduur oplevert. 
The study described is based on the supposition that delay during treatment of patients, could cause long-term illnesses. In fact in the region of Southern Limburg where the study is conducted, the so-called waiting periods during treatment could have an even more extensive consequence than elsewhere in the Netherlands. Thus, as part of a larger project based on the sickness absenteeism in southern Iimburg, the study has been undertaken to test and elaborate this supposition.

To this end the study comprised a good 200 employees absent from work for four consecutive weeks due to illness. Details were collected concerning their personal particulars, their illnesses, employment, their possible return to work and about the manner in which they were treated as patients. In this way a number of characteristics were registered related to the contacts between respondents and representatives of the health care system. This included the exact date of the contact, the type of health care assistance and the initiator of the contact. The registration extended over the period from the date of reporting sick to the date of resuming employment or the dates of entry into the Social Disability services or any other form of discharge from employment.

The participation in the study of employees with long-term illnesses progressed so favourably that the final survey did not distinguish itself significantly from the non-participants where it concerned the important characteristics of age and sex. Consequently, the survey could be considered as reasonably representative for the population of southern Limburg. However, the research results are only applicable for the entire Dutch situation, where they concern the explanatory analysis.

A primary objective of the study was directed towards describing the waiting periods experienced by patients in southern Limburg during their treatment. These waiting periods in southern Limburg could be compared with comparative figures from North/South Holland in 1974/1975. It was learnt from this comparison that the for-age-correctednet-percentage of waiting time was a good 2,58 higher in Southern Limburg than in North/South Holland (1974/1975). 
Altogether, the waiting periods in Southern Limburg amount to 22,18 of all the days, employees with long-term illnesses are absent from work. The waiting periods are namely centred around hospital admittance and the periods of waiting for further course of action. These latter periods lack a definite line of treatment. The problem first-mentioned is presumably connected to the coefficient of high hospital admittance present in southern Limburg, while the second problem is probably due to the lesser directive instructions of the insurance company doctors of the GAK*. The duration of the referrals to orthopedias and rheumatologists in Southern Limburg, is longer than the referrals to all other specialists; this is also true of North/South Holland.

Finally, the impression exists that insurance company doctors do not function consistently, where it concerns the follow-up of absenteeism, perhaps due to the organizational system in which they are employed.

878 of the respondents have either fully or partly resumed employment at the end of the registration period and a good $1 / 3$ of all the respondents have at some time during their period of illness spoken about the possibility of acquiring adapted employment. This finally resulted in 39 respondents $(=248$ ) resuming employment with a definite or temporary adaptation to their type of work. Usually it also entailed a temporary change in the working hours. Although in many respects persons resuming employment ofter did not feel completely satisfied with the manner in which it proceeded. out of the 24 persons not resuming employment, 10 respondents made it known that although they were officially declared unable to work, they themselves did feel capable of working.

In the Dutch situation is meant, one of the Social. Security Institutions that detemine, whether or not an employee can be declared able to return to work. 
The second part of the research results concerned the differences between patients with regard to the duration of the waiting periods and the illness pexiods. In addition, the watting periods can be distinguished into two types: namely. the period of waiting for a referral and the period of wating for further course of action. Moreover, the factors which lead to a greater chance of referral were studied in order to learn, which respondents have at aIl experienced periods of waiting for a referral. These analyses have successively produced the following insights:

- patients have more chance of being referred to a specialist when the specialized care given at the nearby hospital is more differentiated and when the treatment given at commencement of the illness appears doubtful to the patient;

- furthermore, patients with a greater work-satisfaction and a more stable past working record have a better chance of being referred; this is probably due to the fact that these persons suffer relatively more objective complaints.

The duration of the wating period for referred patients is wholly dependent upon the urgency of their complaints. Only those patients who have previously been absent for the same complaint or who have previously consulted a physician for the same complaint, experience a relatively longex waiting period for a referral. Naturally, the opposite is the case where acute complaints such as accidents are concerned. The period of waiting for further course of action especially occurs in the case of those employees who are ill, but without a past record of the same complaints; and fuxther in the case of employees, who suffer a complaint that lies more in the nature of a general physical or general depressive state. Besides, it is those persons who are insured by the National. Sickness Funds and who experience a lesser worksatisfaction that seem to undergo a longer period of waiting for further course of action.

The final analysis concerns the differences between patients with regard to duration of illness periods. The duration of the 11 lness period is relatively longer when patients indicate more health complaints, when they have a combination of different illnesses and/or a complaint with a long past record. Long-term illnesses occur more frequently amongst 
patients insured by the GAK* and the National sickness Funds, i.e., amongst patients with lower incomes and employed in the private industrial sector. Patients also experience longer illness periods when they are less satisfied with their work situation, receive fewer visits from colleagues during their term of illness and who resume work with one or more work-adaptations.

Finally, patients are generally ill for longer periods when their voluntary visits to the general practitioner are less frequent, when the size of the general practice is smaller and when they are more satisfied about their relationship with the general practitioner. 
LITERATUURLIJST.

An: Modell einer allgemelner Vorsorge-Untersuchung; Arbeitsund Sozlal-Ministerium, Baden-Wirtemberg, Stuttgart, 1970.

An.: Perspectievennota Zuid-Limburg, Maastricht, 1978.

AARTS, L., BRUINSMA, H. en JONG de, Ph.: Arbeidscapaciteit van WAO-toetreders; Sociale verzekeringsraad, zoetermeer, 1982a.

AARTS, L., BRUINSMA, H., JONG de, Ph.: Beschrijving van WAOtoetreders:

In: Sociaal Maandblad Arbeid; 1982b, pp. 579-586.

ABEL-SMITH, B.: Value for money in health services; London, 1976.

ACKOFF, R.L. SASIENI, M.W.: Fundamentals of operations research; Wiley, New York, 1968.

ADRIAANSE, H., DROP, M.J., HALFENS, R, en PHILIPSEN, H.: Leeft Nederland $0 . K . ?$ Verslag van een onderzoek naar de beleving, opvattingen en gedragingen inzake gezondheid; VNz, zeist, 1981.

AERT van J.H. \& HOEKSMA, B.H.: De polikliniek als schakel in de gezondheidszorg;

In: Medisch contact; 1980 (35), pp. 45-59.

ALING, H.: De mindex vallde oudere werknemer; v. Gorcum, Assen, 1969.

ANDRIESSEN, $S$, HOLTHUIS, $R_{0}$ en PRINS, R.: Sociaal-medische betrokkenheid bij ziekte- en arbeidsongeschiktheidsregelingen, een internationale verkenning; CCOZ, Amsterdam, 1983.

APPEIS, A.: Cultuur en ziekte; oratie Rijksuniversiteit Limburg, 1982. 
BADURA, B. (Hg.): Soziale Unterstitzung und chronische Krankheit; zum stand sozialepidemiologischer Forschung; Suhrkamp, Frankfurt am Main, 1981.

BAX, E.H.: De stijging van de arbeidsongeschiktheid in de jaren zeventig. Beleid en analyse.

In: Mens en Maatschappij; 1982 (57), pp. 117-144.

BLACKWELL, B.: The literature of delay in seeking medical care for chronic illnesses;

In: Health Education Monographs; $1963(16), 3$, pp. $3-31$.

BLALOCK, H.M.: Social statistics; MC Graw-Hill, New York, 1972 .

BOSCH v.d., F.A.J. en PETERSEN, C.: De omvang van de verborgen werkloosheid in de WAO.

In: Economisch Statistische Berichten; 1980 (65), pp. $52-58$.

BOSCH v.d., F.A.J. en PETERSEN, C.: Gezondheidszorg en axbeidsongeschiktheid. Een eerste benadering van een (macro-) economisch (her-)allocatie-vraagstuk;

In: Openbare Uitgaven, 1982 (14), pp. 37-55.

BOOTS, J.M.J.: Het werk van de huisarts; dissertatie Rijksuniversiteit Limburg, 1983.

BOUDON, R.: De logica van het sociale; een inleiding tot sociologisch denken: Samson, Alphen a/d Rijn, 1981.

BUIJS, P.C.: Curatieve gezondheidszorg, ziekteverzuim en arbeidsongeschiktheid.

In: V.Ch. Vrooland (ed.): Werk en Gezondheid; over ziekteverzuim en humanisering van de arbeid: Samson, Alphen a.d. Rijn, 1982, pp. 260-271,

CALVO, A.B. MARKS, D.H.: Location of health care facilities: an analytical approach;

In: Socio-econ. Plann. Sci., 1973 (7), pp. 407-422. 
CASSEE, E.W.: Naar de dokter; dissertatie, Boom, Meppel, 1973.

CHILD, D.: The essentials of factor analysis; Holt, Rinehart en Wiriston, London, 1976.

CREMERS, A.G.P.: Kwantificering van zorg in het algemeen ziekenhuis: diss. R.U. Utrecht, 1974.

CROUSEN, A.M.F.B. Analyse van het werk van een controlerend geneeskundige voor de ziektewet; dissertatie K.u. Nijmegen, 1968 .

CULYER, A.J.: Need and the National Health Service; economics and social choice; Martin Robertson, oxford, 1979.

DAVIS, F.M.: Passage through cxisis: polio victims and their families; New York, 1963.

DIEDERIKS, J.P.M.: Herstel en revalidatie na hartinfarct; Diss. Rijksuniversiteit Limburg, 1982.

DIRKEN, J.M.: Het meten van stress in industriële organisaties; dissertatie R.U. Groningen, 1967.

DOORN-de LEEUW van, M.: Wile gaat de gezondheidszorg beheersen?

In: Beleid \& Matschappij, 1977 (5), pp. 141-147.

DOPHEIDE, J.P.: Verwijzingen door de huisarts;

In: Gezomaheld en Samenleving, 1982 (3), Pp. 141151.

DOPHEIDE, J.P. en NIJHOUT, F.P.: Een ziekenhuis op nieuw land; Nederlands Huisartsen Instituut, Utrecht, 1983.

DROP, M.J. en HOUBEN, G.: Gezondheid en ziekte als maatschappelljke verschijnselen;

In: Aakster, C.W. \& Kuiper, G.: Leerboek medische sociologie, Wolters-Noordhof, Groningen, 1983. 
DIJKSTRA, A. \& TORDOIR, W.F.: Samenwerking tussen bedrijfsarts en huisarts;

In: Medisch Contact, 1974 (29), pp. 680-684.

DIJKSTRA, A.: Stigmatisering; Maatschappelijke gevolgen van een afwijkend uiterlijk; Lemniscaat, Rotterdam, 1979.

DIJKSTRA, A.: Ziekteverzuim en non-response;

In: Gezondheid en Samenleving, 1981 (2), pp. 266273 .

ECONOMISCH TECHNOLOGISCH INSTITUUT LIMBURG: Jaarverslag voor de arbeidsmarkt; Maastricht, 1980.

ENOS, D.D. S SULTAN, P.: The soclology of health care: social, economic and political perspectives: Praeger, New York, 1977.

ESCHWEILER, W. HINZE, D. en NIEDER, P.: Beschreibung und Ergebnisse einer empirischen Untersuchung zur Erfassung der Ursachen von Fehlzeiten;

In: Nieder, P. (Hg.): Fehlzeiten, ein Unternehmeroder Arbeitnehmerproblem? Wege zur Reduzierung von Fehlzeiten; Frankfurt am Main, 1979, pp. 109-130.

ETREN van, G. en RUTTEN, F: Health policy and health services research in the Netherlands;

In: Social Science and Medicine, 1983 (17), pp. 119-126.

EVANS, R.G.: Supplier-induced demand: some emplrícal evidence and implications;

In: Perlman, M. (ed.): The economics of health and medical care; London, 1974, pp. 162-173.

EIJK van, J.T.M.: Levensgebeurtenissen en ziekte dissertatie K.U. Nijmegen, 1979. 
FIELDING, A.: Binary segmentation: the automatic interaction detector and related techniques for exploring data structure;

In: O"Muircheartaigh, C.A. \& Paine, C.: Exploring data structures; Wlley and Sons, Chicester, 1978, pp. $125-158$.

FILET, B.C.: Kortsluiting met de bureaucratie; Samson, Alphen a/a Rijn, 1976.

FROST, C.E.B.: How permanent are NHS waiting lists?

In: Social Science and Medicine; 1980 (4), pp. $1-11$.

FUCHS, V.R.: The growing demand for medical care;

In: The New England Journal of Medicine, 1968 (279), pp. 190-195.

GAAG van der, J.: An econometric analysis of the Dutch Health care system; dissertatie R.U. Leiden, 1978.

GEMEENSCHAPPEIIJK MEDISCHE DIENST: Jaarverslag 1979, Amsterdam.

GERRITSMA, J.G.M. en SMAL, J.A.: De werkwijze van huisarts en internist, een vergelijkend onderzoek met behulp van een interactieve patiëntensimulatie; dissertatie R.U. Utrecht, 1982.

GRAAF de, L., KAPPEYNE VAN DE COPPELLO, A. en REIJDEN van der, J.P.: Adviesaanvrage inzake sociaal-medische begeleiding bij ziekteverzuim- en arbeidsongeschiktheidsregelingen aan de Nationale Raad voor de volksgezondheid; 's Gravenhage, 1983.

GREENWALD, H.P., BECKER, S.W. \& NEVITT, M.C.: Delay and noncompliance in cancer detection, a behavorial perspective for health planners;

In: Millbank Memorial Fund Quarterly / Health and Society, 1978 (56), pp. 212-230. 
GREEP, J.M.: Medische technologie, pro en contra's;

In: Een halve eeuw gezondheidszorg: 1950-2000; afscheidsbundel voor Prof. J.C.M. Hattinga-Verschure, utrecht, $1983 \mathrm{a}$.

GREEP, J.M.: Medical manpower planning in the Netherlands; In: Jaspers, F.C.A., Tarlov, A.R. en Vrijland, E.I.: Health manpower planning; Martinus Nijhof Publishers, Boston etc., 1983b.

GROND, J.Th.H.: De scheiding van behandeling en controle;

In: Tijdschrift voor Sociale Geneeskunde, 1980 (58), pp. 669-678.

GROND, J.Th.H. en PATER de, D.: Arts en arbeidsongeschiktheid;

In: Medische contact, 1980 (37), pp. 1131-1136.

GROOT de, M.J.W.: Het ziekteverzuim en de functionering van het medisch apparaat;

In: Mens \& Onderneming, 1967 (21), pp 3-24.

GROOTHOFF, J.: Gezondheidszorg en 3e-maands verzuimgevallen; In: Tijdschrift voor Sociale Geneeskunde, 1981 (59), pp. 42-49.

HERWEIJER, M. : Arbeidsongeschiktheid als vorm van vervroegde uittreding.

In: Gerontologie, 1981 (12).

HOOF van, J.A.P. en Nas, P.: Enkele karakteristieken van het ziekteverzuim in een aantal bedrijven uit Maastricht en omgeving; K.U. Mijmegen, 1967.

HOOGENDOORN, D.: Dalende landelijke sterfte aan acuut hartinfarct en aan andere ischemische hartziekten; In: Nederlands Tijdschrift voor Geneeskunde, 1982.

HOOYMANS, E.M.: Schattingen van een model van de Nederlandse gezondheidszorg over de jaren 1974, 1975 en 1976; In: Gezondheid \& Samenleving, 1983 (4), pp. 110118 . 
HULL, C.H. and NIE, N.H.: Statistical package for the social sciences, update; McGraw-Hill, New York, 1979.

HUMMEL, H.J., KAUPEN-HAAS, H. \& KAUPEN, W.: The referring of patients as a component of the medical interaction; In: Social Science and Medicine, 1970 (3), pp. 597607.

HUNFELD, A.: Werkloosheid, WAO en ABP.

In: $\mathrm{CCOZ}$ : WAO en werkgelegenheid; Amsterdam, 1980.

ILLICH, I.: Limits to medicine; Medical Nemesis: the expropriation of health; Midalesex, 1976.

JANSSEN, B. en YKEMA, J.: Arbeid als medicijn; het belang van soctale "Zeitgebers";

In: Intermediair, $1983(19-37)$, p. 31-37.

JESSEN, J. A.a.: Medische Consumptie; Sociologisch Instituut, Groningen, 1974.

JONG de, Ph., BRUINSMA, H., AARTS, L. en HOP, J.P.: Determinantenonderzoek WAO: een eerste totalibeeld; SVR, zoetermeer/Leiden, 1981.

KARMAUS, W.: Working conditions and health: socal epidemiology, patterns of stress and change; paper presented at the 8 th international conference on social science and Medicine; Stirling, 1983.

KINSTON, W.: Resource consumption and future organization of medical work in the National Health Service;

In: Social Science and medicine, 1982 (16), pp. $1619-1626$.

KLAAUW van der, M.M.: Aanvullende rapportering over het onderzoek: Gezondheidszorg en lange ziekteduren; NIPG/TNO, Leiden, 1979.

KNIBBE, R.A.: Probleemarinken in Limburg; Rijksuniversiteit Limburg, Maastricht, 1982. 
KOOY v.d., S.: Overdracht van gegevens tussen de verzekeringsgeneeskundig en de behandelende sector;

In: T. v. Soc. Gezondheidszorg, 1983 (61), pp. $672-674$.

KRUIDENIER, H.J.: Het verwijzen door huisartsen; afstand tot ziekenhuis van invloed op verwijspatroon;

In: Inzet, 1977 (1), pp. 32-39.

KRUIDENIER, H.J.: Ziekteverzuim 1977-1980: enkele cijfers uit het registratiesysteem van de stichting $\mathrm{CCOZ}$; Amsterdam, 1982.

LAMERS, L.: Beleidsinformatiewensen van informatie-uitwisseling;

In: T. v. Soc. Gezondheidszorg, 1983 (61), pp. 660663.

LANDELIJK INFORMATIESYSTEEM ZIEKENFONDSEN: Jaarverslag; Zeist, 1980.

LEVITAN, S.A. and TAGGART, R.: Employment problems of disabled persons;

In: Monthly Labor Review, 1977, pp. 3-13.

LUDKE, R.I.: An examination of the factors, that influence patient referral decisions;

In: Medical Care, 1982 (20), pp. 782-794.

LUYCKX, R.TH. De lotgevallen van de langverzuimer; Diss. R.U. Groningen, 1982 .

MAGNUSSON, G.: The role of proximity in the use of hospital emergency departments;

In: Sociology of health and illness, 1980 (2), pp. $202-227$.

MANSVELT Van, J. BRUNSTING, R.L., DELAMARRE, B.J.M. en WAAL van der, H.A.: Een onderzoek naar oorzakelijke factoren en bijzondere kenmerken bij het langdurend arbeidsverzuim, I en II;

In: Sociaal Maandblad Arbeid, 1975, pp. 307-321 en pp. $379-389$. 
MANSVELT van, J.: Aanbevelingen tot structurele veranderingen van de zlektewet/WAO en de daarbij behorende beoordelingsprocedures;

In: Medisch Contact, 1975 (30).

MAXWELI, A.E.: Multivariate analysis in Behavorial Research; Chapman and Hall, London, 1977.

MAYO, E.: The social problems of an industrial civilization; Boston, Harvard, 1945.

MCKENNELI, A.C.: Attitude scale construction;

In: O'Muircheartalgh, C.A., Paine, C.: Exploring data structures; Wiley \& Sons, Chicester, 1978, pp. $183-220$.

MCKINLAY, J.B.: Some approaches and problems in the study of the use of services - an overview:

In: Journal of Health and Social Behavior, 1972 (13), pp. 115-152.

MCKINLAY, J.B.: Social network influences on morbid episodes and the career of help seeking:

In: Eisenberg, L. \& Kleinman, A.: The relevance of social science for medicine; Reidel, Dordrecht/Boston, 1981, pp. 77-110.

MECHANIC, D.: The growth of bureaucratic medicine; an inquiry into the dynamics of patient behavior and the organization of medical care; New York, 1976.

MECHANIC, De: Medical Sociology, second edition; Free Press, New York - London, 1978.

MECHANIC, D.: Correlates of physician utilization: why do major multivariate studies of physician utilization find trivial psychosocial and organizational effects?

In: Journal of Health and Social Behavior, 1979 (20), pp. 387-396. 
MERENS-RIEDSTRA, H.S. en ENDE van, W.J.: verslag van een onderzoek naar samenwerking van artsen; In: Medisch Contact, 1973 (28), pp. 717-721.

MERENS-RIEDSTRA, H.S.: Leven zonder werk; een sociaal-wetenschappelijk onderzoek naar arbeidsongeschiktheid; Diss. Rijksuniversiteit Limburg, 1981.

MELKER de, R.A.: Knelpunten in de samenwerking huisarts-specialist;

In: Medisch Contact, 1974 (29), pp. 6-11.

MILLARD WALTZ, E.: Soziale Factoren bei der Entstehung und Bewältigung von Krankheit, ein Uberblick uber die empirische Literatur;

In: Badura, B. (ed.): Soziale Unterstitzung und chronische Krankheit. Zum stand sozialepidemiologischer Forschung; Suhrkamp, Frankfunrt am Main, 1981, pp. 40-119.

MOOTZ, M.: Ziekenfondslidmaatschap en het raadplegen van de huisarts:

In: Medisch Contact, 1978 (33), pp. 1465-1468.

MOOTZ, M.: Sociale indicatoren, gezondheidstoestand en verzekeringsvorm;

In: Medisch Contact, 1980 (35), pp. 857-860.

MooTz, M.: De patient en zijn naasten; de invloed van houdingen in het persoonlijk netwerk van de patient op zijn medische consumptie; Diss. Rijksuniversiteit Limburg, 1981.

MOOY, T.: Multi-level onderzoek van samenwerking in het parttime-onderwijs;

In: Mens \& Maatschappij, 1980 (55), pp. 148-169.

MORRIS, J.N.: Social inequalities undiminished;

In: T. v. Soc., congres-appendix "Ongelijkheid in gezondheid en gezondheidszorg", 1980, pp. 13-18. 
NAGI, S.Z. , MCBROOM, W.H. and COLLETTE, J.: Work, employment and the disabled;

In: The American Journal of Economics and Sociology, 1969, pp. 21-34.

NAGI, S.Z. en HADLEY, L.W.: Disability behavior: income change and motivation to work:

In: Industrial and labor relations review, 1972, pp. $223-233$.

NEVEN, E.J.J.: Uitstelduur en praktijkvoering; dissertatie Rijksuniversiteit Limburg, 1980.

NIE, N.H., Hull, C.H., Jenkins, J.G., Steinbrennex, K., Bent, D.H.: statistical package for the social sciences, second edition; McGraw-Hill, New York, 1975 .

NUNNALLY, J.C.: Rsychometric theory; McGraw-Hi11, New York, 1967.

NIJHUIS, F. en SOETERS, J.: Werk en Ziekte, een onderzoek naar afwezigheid wegens ziekte en arbeidsongeschiktheid bij 51 organisaties in z-Limburg: Rijksuniversiteit Limburg, Maastricht, 1982.

NIJHUIS, F., SCHROER, C. en SOETERS, J.: Gezondheidszorg en arbeidsongeschiktheid, een reactie op van den Bosch en Petersen;

In: Openbare Uitgaven, 1983 (15), pp. 90-93.

OSS van, M.G.M.: Verzekeringssoort en verpleegdagengebruik; dissertatie K.U. Nijmegen, 1980.

PETERS, J.H. en BREE van, J.H.M.: Project samenwerking eerste en tweede lijn in het ziekenhuis oudenrijn te Utrecht;

In: Medisch Contact, $1979(34)$, pp. 3-9.

PHILIPSEN, H.: Afwezigheid wegens ziekte; Diss. Universiteit van Amsterdam; Wolters-Noordhof, Groningen, 1969a. 
PHILIPSEN, H.: Steekproeven; Oratie, Rijksuniversiteit Leiden; Leiden, $1969 \mathrm{~b}$.

PHILIPSEN, H.: Ziekteverzuim en het ziekenhuis; In: Kliniek en Maatschappij, Lochem, 1973, pp. 54-69.

PHILIPSEN, H.: ziekteverzuim in hoofdlijnen; Rijksuniversiteit Limburg, Maastricht, 1977.

PHILIPSEN, H. en HALFENS, R.: Niet-werken en gezondheid: een vergelijking van arbeidsongeschikten, vervroegd gepensioneerden en werklozen met werkende mannen; In: Gezondheid \& Samenleving, 1983 (4), pp. 161167.

PLOEG v.d., H.: Persoonlijkheid en medische consumptie; Diss. Universiteit van Amsterdam; Swets \& Zeitlinger, Lisse, 1980.

POSTHUMA, B.H. en ZEE van der, J.: Verwijscijfers en de verkleining van de huisartspraktijk;

In: Gezondheid en Samenleving, 1980 (1), pp. 59-68.

QUERIDO, A.: The efficiency of medical care: a critical dism cussion of measuring procedures; stenfert kroese, Leiden, 1963.

RIS, B.G.M.: Personeelsbeleid en ziekteverzuim; NIPG/TNO, Leiden, 1978.

RUTTEN, F.F.H.: The use of health care faclitiles in the Netherlands; Diss. R.U. Leiden, 1978.

RUTTEN, F.F.H.: Privatisering en deregulering in de gezondheidszorg; Oratie Rijksuniversiteit Limburg, 1983.

SCHOKKING-SIEGERIST, E.C.: ziekteverzuim van vrouwelijke werknemers; NIPG/TNO, Leiden, 1979.

SCHRIJVERS, G.: Reglonalisatie en financiering van de Engelse, zweedse en Nederlandse gezondheidszorg; Diss. Rijksuniversiteit Limburg; Lochem, 1980 . 
SCHULTZ-WILD, R.: Betrlebliche Beschäftigungspolitik in der Krise; Frankfurt/New York, 1978.

SITTER de, L.U.: Naar nieuwe fabrieken en kantoren; WoltersNoordhof, Groningen, 1981 .

SMULDERS, P.G.W.: Zlekteverzuim en de samenwerking tussen huisarts, verzekeringarts en bedrijfsarts;

In: Mens \& Onderneming, 1975 (29), pp. 51-67.

SOCIAAL-ECONOMISCHE RAAD: Advies vermijdbaar verzuim wegens ziekte en arbeidsongeschiktheid; "s-Gravenhage, 1982 .

SOETERS, J.: Parttime-arbeid en oxganisatie, een afbakening van voorwaarden, gevolgen en kansen; Doct. scriptie, K.U. Nijmegen, 1978.

SOETERS, J.: Afwezigheid wegens ziekte in het Herstructureringsgebied $Z$-Limburg; Rijksuniversiteit Limburg, Mastricht, 1980.

SOETERS, J.: Afwezigheid wegens ziekte als regionaal probleem; het geval van z-Limburg.

In: Gezondheid \& Samenleving, 1980 (1), pp. 255265.

SOETERS, J.: Arbeid, organisatie en arbeidsongeschiktheid; In: Gezondheid \& Samenleving, 1983 (4), pp. 13-21.

STIMSON, G. and WEBB, B.: Going to see the doctor; the consultation process in general practice; London/ Boston, 1975.

STRENG, J.C.: Het handelen van artsen bij ziekteverzuim;

In: T. v. Soc. Gezondheidszorg, 1983 (61), pp. $646-651$.

SWAAN de, A.: De mens is de mens een zorg; Meulenhof, Amsterdam, 1982 .

SUCHMAN, E.A.: Social patterns of illness and medical care; In: Journal of Health and human behavior, 1965 (6), pp. 2-16. 
TAGLIACOZZE, D.M. \& IMA, $K_{*}$ : Knowledge of illness as a predictor of patient behavior;

In: Journal of chronic disability, 1970 (22), pp. $125-130$.

TORDOIR, W.F., KLAAUW van der, M.M. en MANEN-BOEKESTEIN van, C.M.J.: Gezondheldszorg en lange ziekteduren; NIPG/TNO, Leiden, 1978 .

TUCKETT, D. (ed.): An introduction to medical sociology; Tavistock, London, 1977.

TWADDLE, A.C.: Sickness behavior and the sick role; Schenkman, Cambridge-Massachusets, 1981.

VEN v.d., W.P.M.M., NAUTA, F.A., VLIET van, R.C.J.A., RUTTEN, F.F.H.: Inventarisatie en achtergronden van de consumptieverschillen tussen ziekenfonds- en particulierverzekerden;

In: Gezondheid \& Samenleving, 1980 (1), pp. 224254 .

VICKERS, M.D., et al: waiting for hospital treatment; Harrogate Seminar reports, London, 1980.

VISSER, A.Ph.: De betekenis van de VOEG: enkele gegevens over de begripsvaliditeit;

In: Gezondheid en Samenleving, 1983 (4), pp. 177188.

VLIET, van, R.C.J.A. en VEN V.d., W.P.M.M.: Analyse van verschillen in medische consumptie tussen ziekenfondsen particulierverzekerden:

In: Gezondheid en Samenleving, 1982 (3), pp. 54-72.

WENNBERG, J. \& GITTELSOHN, A.: Small area variations in health care delivery;

In: Science, 1973 (182), pp. 1102-1108.

WET VOORZIENINGEN GEZONDHEIDSZORG: Staatsblad van het Koninkrifk der Nederland, 1982 (563). 
WIERSMA, D.: Psychosociale "stress" en langdurige arbeidsongeschiktheid; Diss." Groningen, 1979.

WILKES, E.: Waiting lists and the general practitioner;

In: Vickers, M.D. et al: Waiting for hospital treatment; Harrogate seminar report, London, 1980.

ZAAL van, M.J.: Wat voeren de uitvoerders uit?

In: Economisch Statistische Berichten, 1981 (66), pp. $28-34$.

ZEE van der, J.: De vraag naar diensten van de huisarts; dissertatie Rijksunivexsiteit Limburg, 1982.

ZOLA, I.K.: structural constraints in the doctor-patient relationship: the case of non-compliance;

In: Elsenberg, L. en Kleiman, A.: The relevance of social science for medicine; Dordrecht, 1981.

ZWEEKHORST, W.A.: Passende arbeid: Knelpunt van de arbeldsongeschiktheidsverzekering;

In: Sociaal Maandblad Arbeid, 1972 (32), pp. 745757. 
$B I J \perp A G E N$ 
BIULAGE I.

SAMENSTLLL ING BEGELEIDINGSCOMMISSIE

H. Rism

Ir. M* Lodewijks

Drs. K. de Jung

Drs. A. Marcet

Ir. J. Coenjaertz

J. Berlott

Drs. P. van son

Drs. P. Stroink

J. Errst

Drs. G. Boer

P. Booij jr:

F' van der Smissen

Ir. E* de Tollenaer

Drs. M. Magielsen

H. Niene

Drs. K. van Amstel
Gedeputeerde Staten van Limburg

(voorzitter tot 1.8 .1982 )

Gedeputeerde Staten van Limburg

(voorzitter v.a. 1. $\cdot 19.1982$ )

Provinciale Griffie van Limburg

(secretiris)

Ministerie van Sociale zaken

Ministerie van Sociale zaken

Ministelie van Economische Zaken

Ministerie van Volksgezordheid en

Milieuhygieme

Sociale verzekeringsraad

Federatie van Bedrijfsverenigingen

Bedrijfsgezondheidszorg $z$-Limburg

Christelijk Nationaal Vakverbond

Industriebond F.N.V.

Limburgse Werkgeversvereniging

I imburgse Werkgeversvereniging

N.V. Industriebank LIOF

Stichting $\mathbb{C} \cdot \mathrm{C} \cdot \mathrm{O} \cdot \mathrm{z}$. 
BIJLAGE BIJ HOOFDSTUK 3.

Non-respons-analyse op een aantal basiskenmerken.

Tabel 3.2.

Weigering en deelname naar leeftija.

\begin{tabular}{|c|c|c|c|}
\hline & weigering & lname & $\begin{array}{l}\text { totaal } \\
(=1008)\end{array}$ \\
\hline $15 \mathrm{t} / \mathrm{m} 24$ jaar & 198 & 818 & 32 \\
\hline $25 t / m 34$ jaar & 168 & 848 & 76 \\
\hline $35 \mathrm{t} / \mathrm{m} 44$ jaar & 178 & 838 & 70 \\
\hline $45 \mathrm{t} / \mathrm{m} 54$ jaar & 228 & $78 \%$ & 54 \\
\hline $55 \mathrm{t} / \mathrm{m} 64$ jaar & 158 & 858 & 27 \\
\hline Totaal & 188 & 828 & 259 \\
\hline
\end{tabular}

$X_{2}=1.19, \mathrm{dgf}=4, \mathrm{~N} . \mathrm{S}$.

Tabel 3.3 .

Weigering en deelname naar geslacht

\begin{tabular}{|lrr|c|}
\hline & weigering deelname & $\begin{array}{c}\text { totaal } \\
(=1008)\end{array}$ \\
\hline man & 188 & 828 & 223 \\
vrouw & 178 & 838 & 36 \\
Totaal & 188 & 828 & 259 \\
\hline
\end{tabular}

$\chi 2=0.03, \operatorname{dgf}=1$, N.S.

Tabel 3.4.

Weigering en deelname naar urbanisatiegraad woonplaats

\begin{tabular}{|lrr|r|}
\hline & weigering deelname & $\begin{array}{r}\text { totaal } \\
(=1008)\end{array}$ \\
\hline platteland & $0 \%$ & $100 \%$ & 3 \\
verstedelijkt platteland & 208 & $80 \%$ & 91 \\
verstedelijkt gebied & 178 & $83 \%$ & 165 \\
Totaal & 188 & $82 \%$ & 259 \\
\hline
\end{tabular}

$\chi^{2}=0.98, \operatorname{dg} f=2, \mathrm{~N} . \mathrm{S}$. 
Tabel 3.5 .

Welgering en deelname naar sector

\begin{tabular}{|lrr|r|}
\hline & weigering deelname & $\begin{array}{c}\text { totaal } \\
(=100 \%)\end{array}$ \\
\hline industrleel & 218 & 798 & 171 \\
niet-industrieel & 118 & 898 & 88 \\
Total & 118 & 828 & 259 \\
\hline
\end{tabular}

$\chi^{2}=3.66, \operatorname{dg} f=1$, N.S. 
BIJLAGE BIJ HOOFDSTUK 4 .

Tabel 4.1 .

Geslacht van respondenten uit onderzoek in de Randstad en z-Limburg

\begin{tabular}{|l|lll|l|}
\hline & Randstad & \multicolumn{2}{|l|}{ Zuid-Iimburg } & Totaal \\
& & GAK & niet-GAK & \\
\hline man & $664(778)$ & $122(898)$ & $61(808)$ & $847(798)$ \\
Trouw & $198(238)$ & $15(118)$ & $15(208)$ & $228(218)$ \\
Totaal & $862(1008)$ & $137(1008)$ & $76(1008)$ & $1075(1008)$ \\
\hline
\end{tabular}

$\chi^{2}=6.9$ voor $\mathrm{z}$-Limburgse GAK-verzekerden in vergelijking met Randstad-respondenten;

$p<0.01$

dgf $=1$

Tabel 4.2.

Nationaliteit van respondenten uit onderzoek in de Randstad en $\mathrm{Z}-\mathrm{L}$ imburg

\begin{tabular}{|l|rrrr|r|}
\hline & Randstad & \multicolumn{2}{|c|}{ Zuid-Limburg } & Totaal \\
& & GAK & niet-GAK & \\
\hline Nederlandse & $812(948)$ & $126(928)$ & $74(978)$ & $1012(948)$ \\
andere & $50(68)$ & $11(68)$ & $2(98)$ & $63(68)$ \\
Totaal & $862(1008)$ & $137(1008)$ & $76(1008)$ & $1075(1008)$ \\
\hline
\end{tabular}

$\chi^{2}=0.99$ voor $z$-Limburgse GAK-verzekerden in vergelijking met respondenten uit Randstad-onderzoek. $\mathrm{dgf}=1 \mathrm{~N} \cdot \mathrm{S}$. 
Tabe1 4.3.

Leeftijd van respondenten uit onderzoek in de Randstad en Z-L imburg

\begin{tabular}{|l|rrrr|l|}
\hline & Randstad & \multicolumn{3}{|c|}{ Zuid-Limburg } & Totaal \\
& & GAK & niet-GAK & \\
$t / \mathrm{m} 25 \mathrm{jr}$. & $151(188)$ & $19(148)$ & $7(98)$ & $177(168)$ \\
$t / \mathrm{m} 35 \mathrm{jr}$. & $182(218)$ & $43(328)$ & $21(288)$ & $246(238)$ \\
$t / \mathrm{m} 45 \mathrm{jr}$. & $178(218)$ & $37(278)$ & $21(288)$ & $236(228)$ \\
$t / \mathrm{m} 55 \mathrm{jr}$. & $188(228)$ & $27(208)$ & $15(208)$ & $230(218)$ \\
$t / \mathrm{m} 65 \mathrm{jr} \cdot$ & $16(198)$ & $11(88)$ & $12(168)$ & $186(178)$ \\
Totaal & $862(1008)$ & $137(1008)$ & $76(1008)$ & $1075(1008)$ \\
\hline
\end{tabular}

$X_{2}=16.9$ voor $z$-Limurgse GAK-verzekerden in vergelijking met respondenten uit Randstad-onderzoek.

$p<0.01$

$\mathrm{dgf}=4$

Tabel 4.4 .

ziekenfondslidmaatschap van respondenten wit onderzoek in de Randstad en $\mathrm{z}$-Limburg.

\begin{tabular}{|l|ccc|c|}
\hline & Randstad & \multicolumn{2}{|c|}{ Zuid-Limburg } & Totaal \\
\hline $\begin{array}{l}\text { zieken- } \\
\text { fondsver- } \\
\text { zekerd } \\
\text { particu- } \\
\text { lier ver- } \\
\text { zekerd }\end{array}$ & $767(898)$ & $131(968)$ & $34(458)$ & $932(878)$ \\
Total & $95(118)$ & $6(48)$ & $42(558)$ & $143(138)$ \\
\hline
\end{tabular}

$\chi^{2}=5.7$ voor $z$-Limburgse GAK-verzekerden in vergelijking met respondenten uit Randstad-onderzoek.

$p<0.05$

$\operatorname{dg} f=1$ 
Tabel 4.9 .

Ter sprake brengen van verzuimcontinuering in $Z$-Limburgse en Randstad-steekproef.

\begin{tabular}{|l|cc|c|}
\hline & $z$-Limburg & Randstad & Totaal \\
\hline $\begin{array}{l}\text { verzuimcontinuering } \\
\text { ooit ter sprake ge- } \\
\text { bracht } \\
\text { verzuimcontinuering } \\
\text { nooit ter sprake ge- } \\
\text { bracht }\end{array}$ & $151(718)$ & $819(958)$ & $970(908)$ \\
\begin{tabular}{l} 
Totaal \\
\hline
\end{tabular} & $213(1008)$ & $862(1008)$ & $1075(1008)$ \\
\hline
\end{tabular}

$x^{2}=112 \cdot 8$

dgf $=1$

$\mathbf{p} \leqslant 0.01$

Tabel 4.10 .

Initiatief tot werkhervatting in $z$-Iimburgse en Randstad-steekproef.

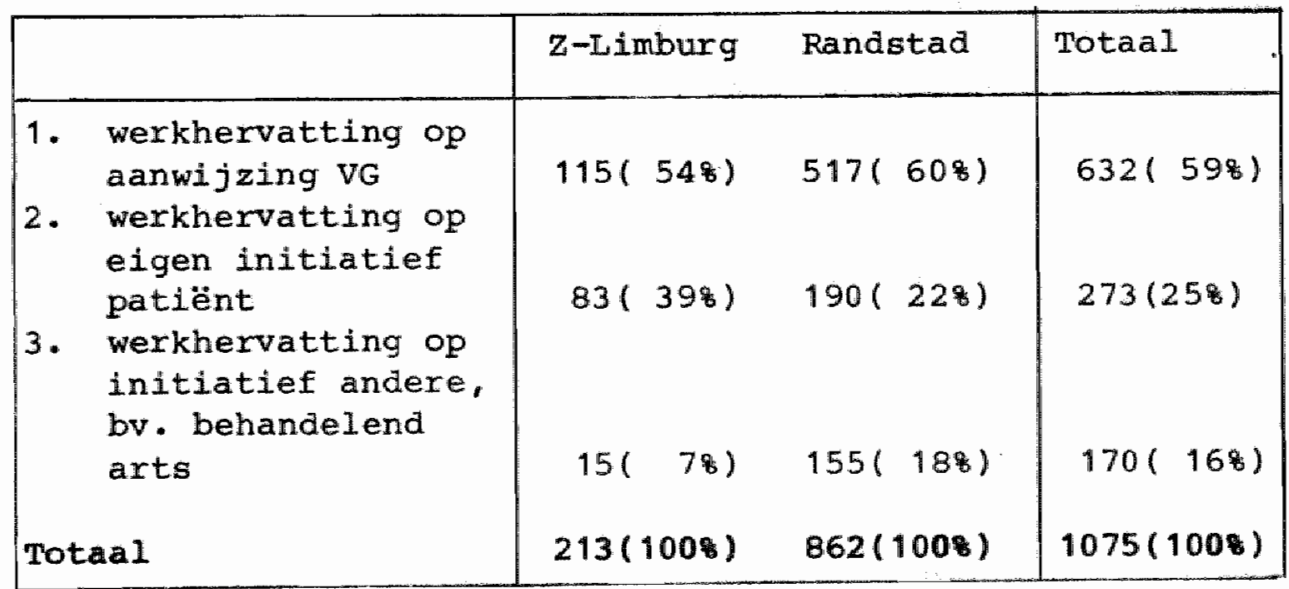

$X^{2}=3.3 .2$

$\mathrm{dgf}=2$

$p \leqslant 0.01$ 
Tabe1 4.11.

De wije waxop vervolgcontacten van resp. GAK-VG-en en andere VG-en tot stand komen (Z-LImburgse steekproef teleenheid is antal contactenl.

\begin{tabular}{|l|lc|c|}
\hline & GAK & niet-GAK & Totaal \\
\hline 1. $\begin{array}{l}\text { vervolgcontact via } \\
\text { oproep } \\
\text { vervolgcontact via } \\
\text { airecte terugbe- } \\
\text { stelling }\end{array}$ & $180(718)$ & $75(328)$ & $225(528)$ \\
Totaal & $74(298)$ & $163(688)$ & $237(48 \%)$ \\
\hline
\end{tabular}

$x^{2}=76.2$

$\mathrm{dgf}=1$

$\mathbf{p} \leqslant 0.01$

Tabe1 4.12 .

Gemiddelde patiëntenoordeelscores over respectievelijk de duidelijkheid van de contacten, het belang ervan voor het herstel en de tijdsduur tot het eerstvolgende contact, gespecificeerd per soort contact (enkelvoudige variantieanalyses $)(\mathrm{N}=3.927$ contacten $)$.

\begin{tabular}{|c|c|c|c|c|c|c|}
\hline & \multicolumn{2}{|c|}{$\begin{array}{l}\text { duidelijkheids- } \\
\text { score }(1-3) \\
\text { laag=duidelijk }\end{array}$} & \multicolumn{2}{|c|}{$\begin{array}{l}\text { belangrijkheids- } \\
\text { score }(1-4) \\
\text { laag=belangrijk }\end{array}$} & \multicolumn{2}{|c|}{$\begin{array}{l}\text { tijasverloop- } \\
\text { score }(1-3) \\
\text { laag=te lang }\end{array}$} \\
\hline & $x$ & s.d. & $x$ & s.d. & $\mathrm{x}$ & s.d. \\
\hline 1. huisarts & 1.1 & 0.38 & 1.6 & 0.95 & 1.9 & 0.24 \\
\hline 2. VG of $B A$ & 1.3 & 0.73 & 3.6 & 0.84 & 2.0 & 0.21 \\
\hline 3. special. & 1.1 & 0.39 & 1.4 & 0.77 & 2.0 & 0.26 \\
\hline 4. paramed. & 1.1 & 0.31 & 1.6 & 1.00 & 2.0 & 0.18 \\
\hline 5. ziekenh. & 1.2 & 0.55 & 1.3 & 0.76 & 1.9 & 0.25 \\
\hline 6. verricht. & 1.0 & 0.23 & 1.3 & 0.68 & 1.9 & 0.21 \\
\hline 7. GGZ & 1.1 & 0.45 & 1.6 & 1.16 & 1.9 & 0.23 \\
\hline B. rest & 1.1 & 0.41 & 2.3 & 1.45 & 2.0 & 0.00 \\
\hline & $F=20.9$ & $p=0.00$ & $F=4.45 .2$ & $p=0.00$ & $F=11.3$ & $p=0.00$ \\
\hline
\end{tabular}


Tabel 4.14

Specificatie van wachttijden voor 55-plussers van de GAKverzekerden $(\mathrm{N}=11)$.

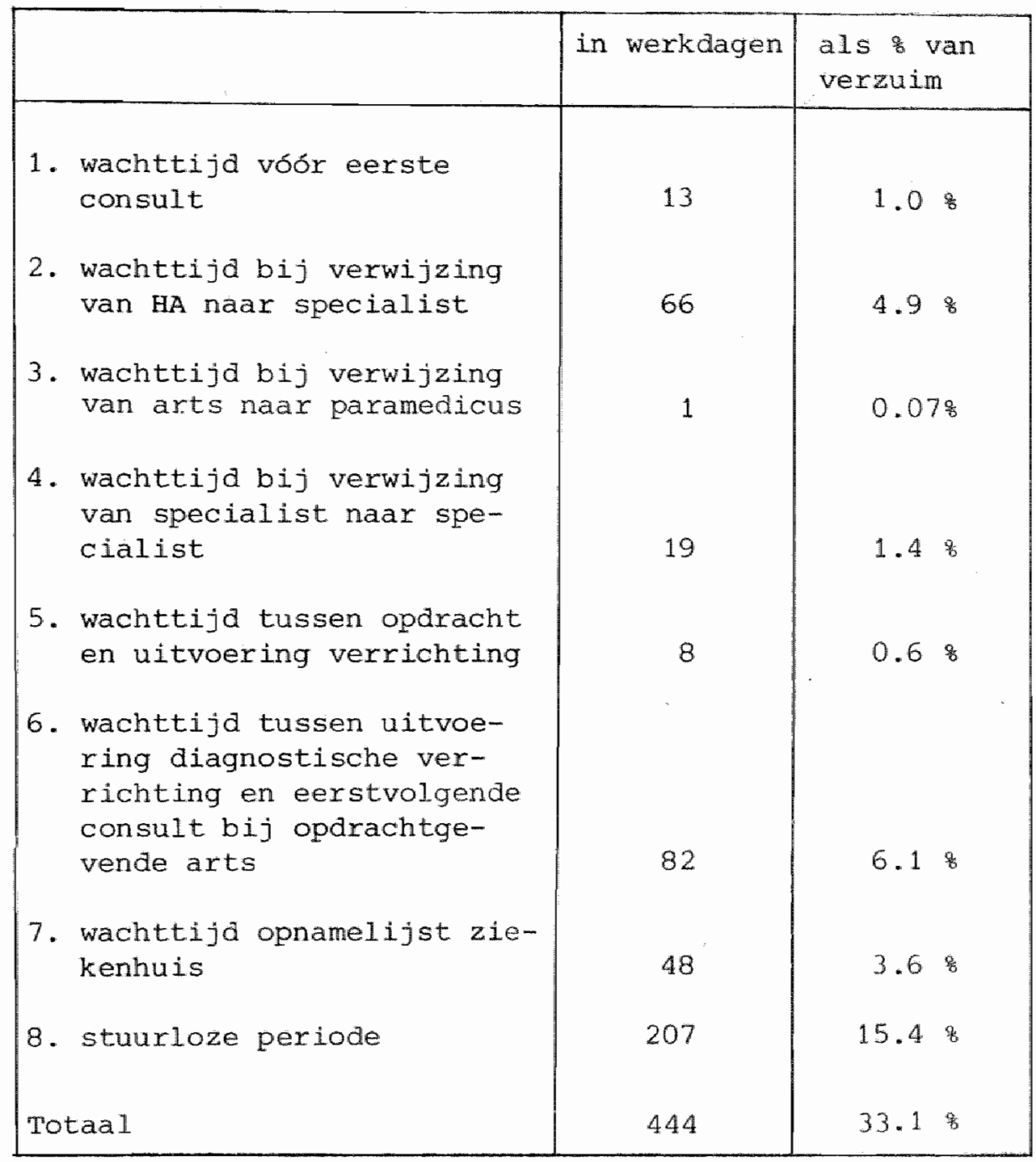




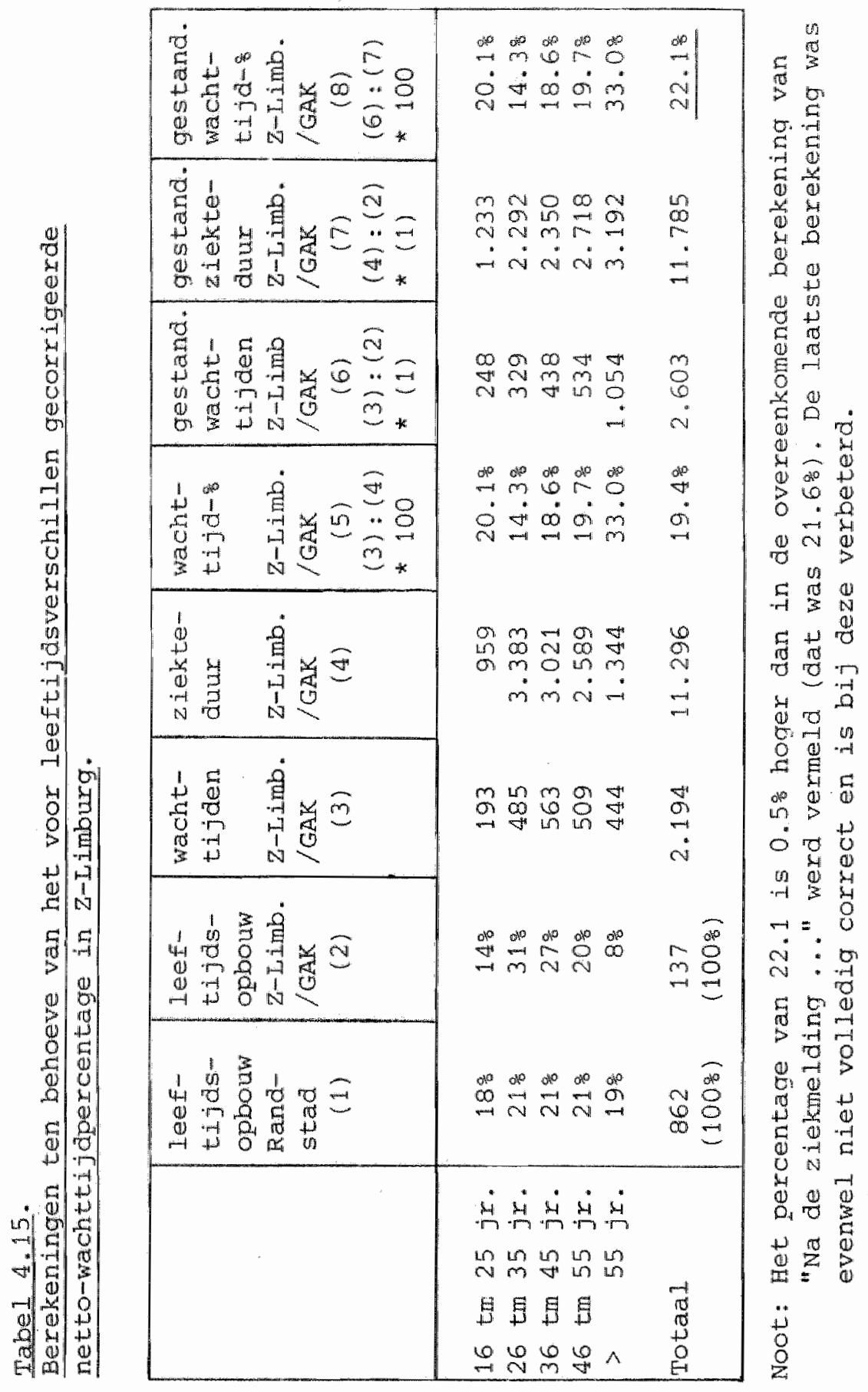


Tabe 14.18 .

Gemiddelde wachttijd voor opname ziekenhuis naar soort speclalisme dat opname indiceert.

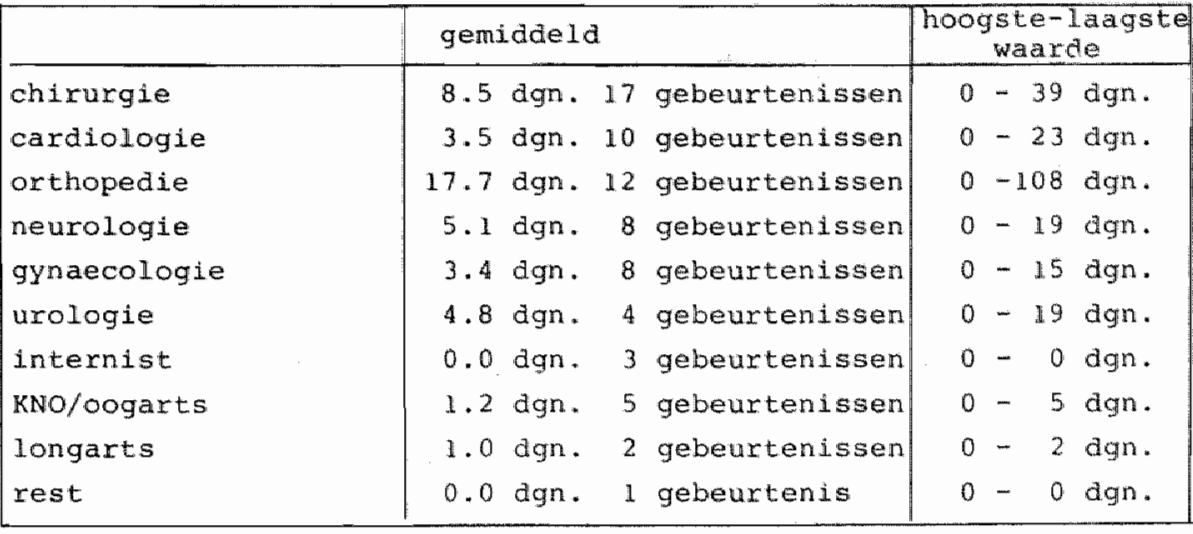

Totaal

$6.9 \mathrm{dgn} .70$ gebeurtenissen

Tabe1 4.19.

Gemiddelde wachttijd tijdens verwijzing van HA naar specialist en van specialist naar specialist, naar soort specialisme.

\begin{tabular}{|c|c|c|}
\hline & gemiddeld aantal & $\begin{array}{c}\text { hoogste-laagste } \\
\text { waarde }\end{array}$ \\
\hline chilrurgie & 1.5 dgn. 15 gebeurtenissen & $0-10 \mathrm{dgn}$. \\
\hline cardiologie & 4.8 dgnn. 6 gebeurtenissen & $0-20 \mathrm{dgn}$ \\
\hline arthopedie: & 8.1 dgn. 18 gebeurtenissen & $0-23$ dgn. \\
\hline neurologie & 4.8 dgn. 14 gebeurtenisisen & $0-14 \mathrm{dgn}$. \\
\hline gynaec./urologie & 6. 3 agn. 3 gebeurtenissen & $0-19 \mathrm{dgn}$. \\
\hline interne geneeskunde & 4.0 dgn. 12 gebeurtenisset & $0-15 \mathrm{dgrn}$ \\
\hline KwO/oogheelkunde & 3.2 dgn. 6 gebeurtenissen & $9 \mathrm{dgn}$. \\
\hline rheumatologie & 12.6 dgn. 5 gebeurtenissen & $4-23 \mathrm{dgn}$. \\
\hline rest & 3 gebeurtendssen & $0-16 \mathrm{dgn}$. \\
\hline
\end{tabular}


Tabel 4.20.

Specificatie van stuurloze periode naar diagnose, alle respondenten.

\begin{tabular}{|c|c|c|c|c|}
\hline & $\begin{array}{l}\text { gemid- } \\
\text { delde } \\
\text { stuurloze } \\
\text { periode } \\
\text { in dgn. }\end{array}$ & $\mathrm{N}=$ & $\begin{array}{l}\text { gemid- } \\
\text { delde } \\
\text { ziekte- } \\
\text { duur }\end{array}$ & $\begin{array}{l}\text { stuur- } \\
\text { loze } \\
\text { periode }\end{array}$ \\
\hline - infectieziekten & 0.0 & 2 & 37.5 & $0.0 \%$ \\
\hline - nieuwromingen & 0.0 & 4 & 188.5 & 0.08 \\
\hline - allergieễn & 13.2 & 4 & 134.3 & $9.8 \%$ \\
\hline $\begin{array}{l}\text { - psychische } \\
\text { ziekten }\end{array}$ & 12.9 & 32 & 73.3 & $17.6 \%$ \\
\hline $\begin{array}{r}\text { - zenuwstelsel } \\
\text { en zintuigen }\end{array}$ & 1.0 & 11 & 103.1 & 1.09 \\
\hline $\begin{array}{l}\text { - circulatie- } \\
\text { apparaat }\end{array}$ & 1.6 & 14 & 136.5 & 1.28 \\
\hline $\begin{array}{l}\text { - ademhalings- } \\
\text { wegen }\end{array}$ & 4.5 & 12 & 89.6 & $5.0 \%$ \\
\hline $\begin{array}{l}\text { - spijsverterings } \\
\text { organen }\end{array}$ & 0.9 & 20 & 65.8 & 1.48 \\
\hline $\begin{array}{l}\text { - urogenitaal } \\
\text { stel sell }\end{array}$ & 1.2 & 8 & 73.9 & $1.6 \%$ \\
\hline - huiaziekten & 0.0 & 5 & 60.4 & $0.0 \%$ \\
\hline $\begin{array}{l}\text { - bewegingsappa- } \\
\text { raat }\end{array}$ & 2.4 & 67 & 72.1 & $3.3 \%$ \\
\hline - misvormingen & 0.0 & 2 & 119.5 & $0.0 \%$ \\
\hline - ongevallen & 2.8 & 33 & 54.4 & $5.2 \%$ \\
\hline Totaal & 3.9 & 213 & 79.0 & $5.0 \%$ \\
\hline
\end{tabular}


Tabe1 4.21 .

Gemiddelde verzuimduur, wacht 1 jen wachteijdenpexcentage voor werkhervatters en niet-hervatters in 2 -Limburg en de Randstad*

\begin{tabular}{|c|c|c|c|c|c|c|c|c|}
\hline & \multicolumn{4}{|c|}{$z$-Limburg } & \multicolumn{4}{|c|}{ Randstad } \\
\hline & $\mathrm{H}=$ & VD & WT & Wris & $\mathbb{N}=$ & $V D$ & wr & WT: \\
\hline hervatters & 196 & 59,2 & 10.8 & 188 & 749 & 59 & 12.7 & 228 \\
\hline niet-hervatters & 27 & 208,3 & 30.3 & 158 & 113 & 228 & 36.8 & $16 \%$ \\
\hline Totaal & 213 & 79.0 & 13.4 & 178 & 862 & 81 & 16 & 208 \\
\hline
\end{tabular}


Tabe1 4.22 .

Gemiddelde wachtt1j per soort in werkagen, voor wekhervatues en

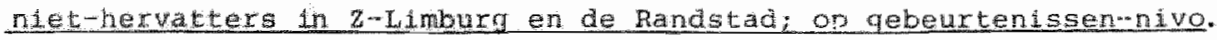

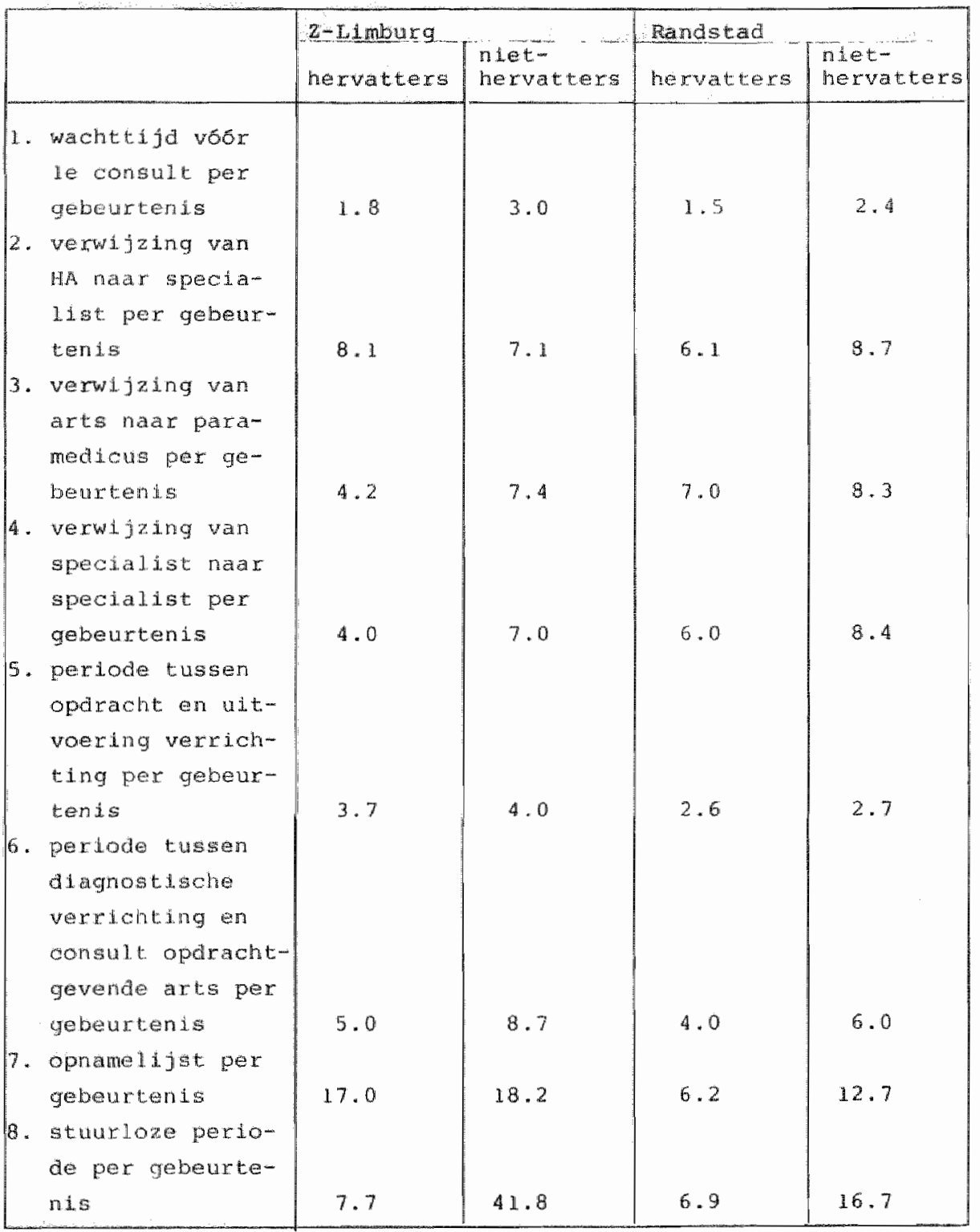


BIJLAGE BIJ HOOFDSTUK 5 .

Tabe 15.4 .

Gesprekspartners bij overleg over aangepaste arbeid voor hervatters en niet-hervatters (tel-eenheid is aantal gesprekken).

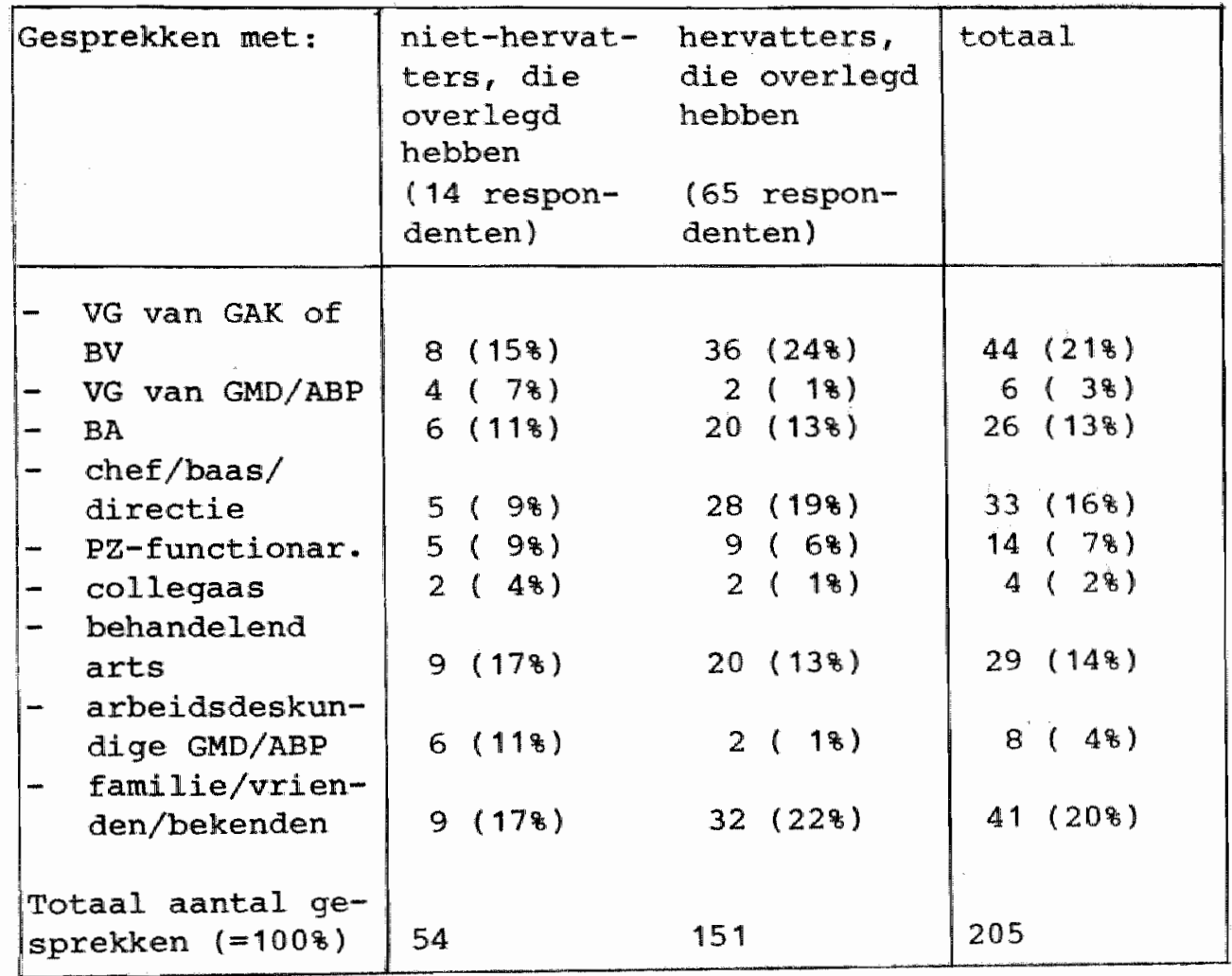

$X^{2}=21 \cdot 0$

$\mathrm{dgf}=8$

$\mathrm{P}=0.01$ 
Tabed. 5.6.

Enkele kenmerken van de personen, die met werkaanpassingen hebben hervat.

- hervat met één aanpassing

- hervat met twee of meer aanpasaingen

- (zeer) tevreden over werkaanpassing(en)

- (zeer) ontevreden over werkaanpassing(en)

geen mening

met werkaanpassing(en) (mede) oorzaak van ziekte verdwenen met werkaanpassing(en) (mede) oorzaak van ziekte niet verdwenen

- weet niet
27 (69)

12 (318) 39 (100

29 (74)

$3(8 \%)$

7 (18\%)

$39(1008)$

$8(318)$

12 (468)

$6(23)$
$26(1008)$

13 *)

(*)

niet van toepassing, omdat oorzaak van ziekte niet in werk gelegen is. 
BIJUAGE BIU HOOEDSTUK 6.

Grafiek 6.1.

Frequentie van verwilzingem naar specialistische zorg per 100 werkdagen aurende ziekteperiode $(N=186)$.

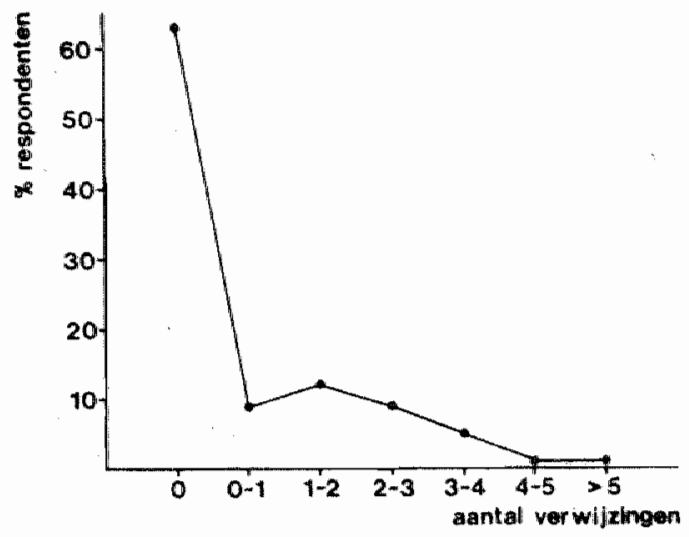

Grafiek 6.2.

Freguentie van aantallen verwijzingswachtdagen en stuurloze dagen per 100 werkdagen durende ziekteperiade $(N=186)$.

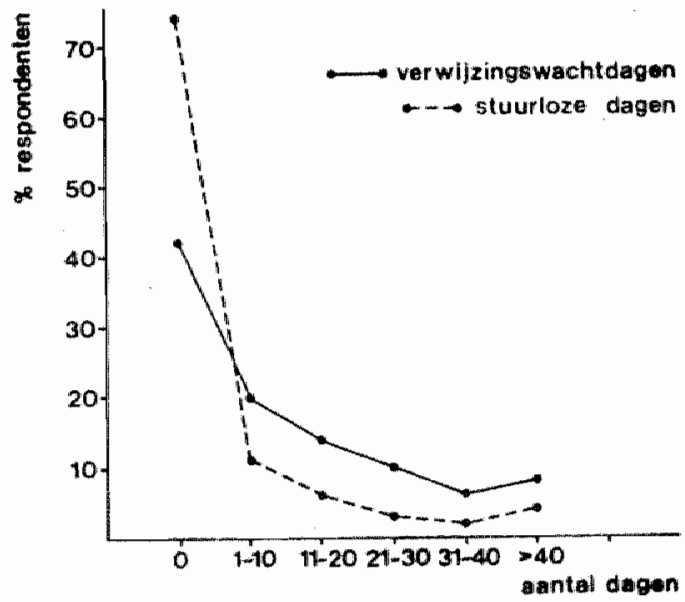


De constructie dex onafhankelijke variabelen

Allereerst zijn alle vragen op basis van overeenkomst op eerste gezlcht in een aantal groepen ingedeeld. Vervolgens is voor elke groep vragen of items een factor-analyse uitgevoerd Iprincipale-componenten-analyse met iteraties, eventueel aangevuld met varimax-rotatie; volgens Nie et al.. 1975). Alle vragen of items met lagere factorladingen dan . 25 zijn hierbij verwijderd; hetzelfae is gedaan met factoren met een eigenwaarde kleiner dan 1 (volgens bijv. Child, 1976). Op grond van deze analyses ontstonden intern consistente variabelen, die vervolgens nog aan betrouwbaarheidsanalyse werden onderworpen (Mckennell, 1978; Hull en Nle, 1979). Via de aldus berekende Cronbach's $\alpha$ kan een indruk worden verkregen van de betrouwbaarheid van de variabelen; dit is belangrijk, ondat de mate van betrouwbaarheid van een variabele rechtstreeks effect sorteert op zijn verklaringskracht (Maxwel1, 1977; Mckennell, 1978). Alle in dit onderzoek geconstrueerde variabelen hebben een $\alpha$-waarde van tenminste .53 en ten hoogste .91. Hiermee zijn de variabelen van "voldoende betrouwbaar" tot "goed" te kwalificeren (Nunnally, 1967).

Hierna zijn alle items per onafhankelijke variabele in dezelfde richting gecodeerd en vervolgens opgeteld. Van een aantal metrische variabelen zijn tenslotte nog logaritmische transformaties berekend, teneinde de scheefheid der verdelingen te verminderen en het effect van extreem hoge waarden te mitigeren (Maxwe11, 1977; Van de ven en Van vliet, 1982). 


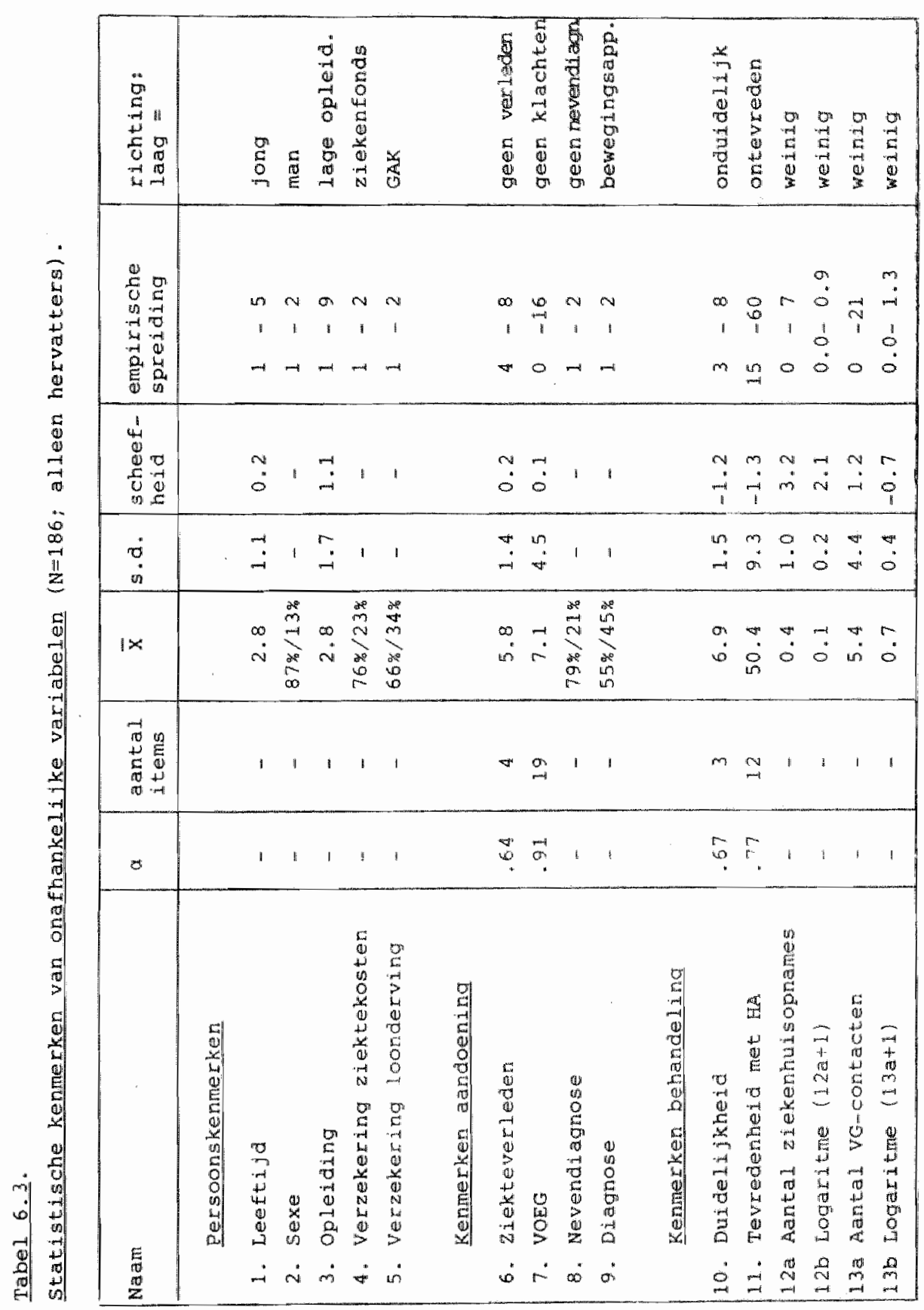




\begin{tabular}{|c|c|c|c|c|c|c|c|c|c|c|c|c|c|c|c|c|c|c|}
\hline 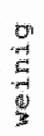 & 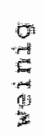 & 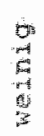 & $\begin{array}{l}a \\
y \\
y \\
y \\
y \\
y\end{array}$ & 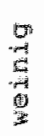 & 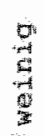 & & $\begin{array}{l}5 \\
5 \\
5 \\
0 \\
0\end{array}$ & $\begin{array}{l}a \\
b \\
b \\
b\end{array}$ & 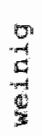 & $\begin{array}{l}-4 \\
0 \\
0 \\
0 \\
0 \\
0 \\
0\end{array}$ & $\begin{array}{l}b \\
0 \\
0 \\
0 \\
4 \\
3\end{array}$ & $\begin{array}{l}0 \\
5 \\
0 \\
0 \\
0 \\
0\end{array}$ & & $\begin{array}{l}9 \\
0 \\
0 \\
0\end{array}$ & $\begin{array}{c}\underset{4}{4} \\
\square \\
0 \\
0\end{array}$ & 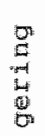 & 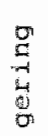 & 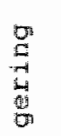 \\
\hline 0 & $ه$ & $m$ & in & & $\infty$ & & & & & & & & & $N$ & $\mathrm{~F}$ & & tn & \\
\hline$\dot{x}$ & i & $\sigma$ & $=4$ & $0:$ & 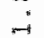 & & $m$ & $\mathrm{CH}$ & ov & $N$ & 0 & 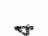 & & 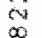 & $\dot{m}$ & 8 & $\therefore$ & $* *$ \\
\hline$w$ & & $\checkmark$ & & 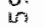 & & & -1 & -1 & $m$ & 8 & 6 & & & $\infty$ & & $n$ & & $r v$ \\
\hline$b$ & $\stackrel{1}{0}$ & 3 & $0_{0}^{11}$ & $i$ & 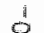 & & 1 & $i$ & 1 & $i$ & 1 & 1 & & 1 & $!$ & $i$ & 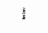 & $\|$ \\
\hline$\dot{0}$ & $\dot{0}$ & 0 & 8 & $\infty$ & 0 & & 0 & 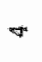 & 0 & 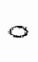 & 0 & is & & 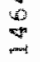 & $m$ & 0 & $\varnothing$ & $n$ \\
\hline in & $r$ & $\forall$ & $r$ & 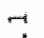 & $m$ & & ?דיה & $\infty$ & in & $m$ & in & $\rightarrow$ & & 0 & 0 & $10 y$ & $r$ & $\infty$ \\
\hline$\ddot{4}$ & $\infty_{1}^{\prime}$ & $v^{\circ}$ & $\dot{0}$ & "ה & $\infty^{\circ}$ & & $\mathrm{C}^{\prime \prime}$ & $\dot{0}$ & $m$ & 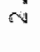 & $m$ & $\stackrel{0}{1}$ & & $=$ & $-i$ & 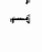 & $\dot{0}$ & $0^{\circ}$ \\
\hline$\infty$ & m. & on & $\nabla$ & $m$ & 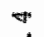 & & in & 0 & $\mathrm{~N}$ & in & an & $\infty$ & & $\infty$ & and & m & or & $\forall$ \\
\hline$m$ & 0 & $\|^{4}$ & 0 & mo & 0 & & $m$ & $-i$ & 0 & in & 0 & $-i$ & & an & 0 & $\begin{array}{l}\infty \\
0\end{array}$ & 0 & $m$ \\
\hline$n$ & in? & $n$ & 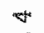 & $\infty$ & in & & $\infty$ & on & $-i$ & $m$ & $\nabla$ & $\Rightarrow$ & & 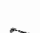 & $*$ & 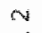 & $m$ & 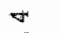 \\
\hline$m$ & 8 & $m$ & 0 & $x$ & 0 & & 撠 & or & 0 & $\infty$ & 0 & 0 & & wh & $m$ & $m$ & 0 & 8 \\
\hline 1 & 1 & 月 & 1 & 1 & 1 & & $m$ & 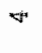 & $\Gamma$ & षr & on & in & & I & 1 & 1 & 1 & $i$ \\
\hline 1 & 1 & 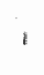 & 1 & 1 & 1 & & $\infty$ & $m$ & 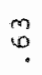 & r & $\mathrm{F}^{2}$ & F & & 1 & 1 & 1 & 1 & 1 \\
\hline 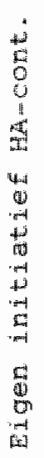 & 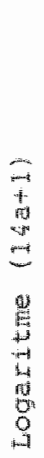 & 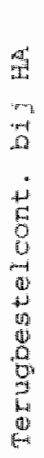 & 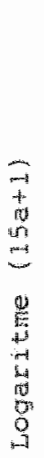 & 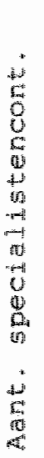 & 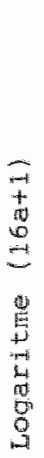 & 要 & 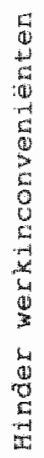 & 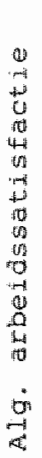 & 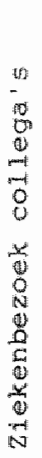 & 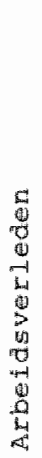 & 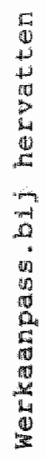 & 步 & 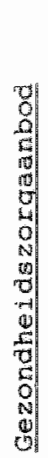 & 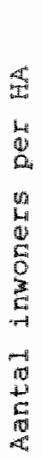 & 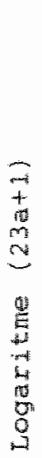 & 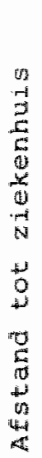 & 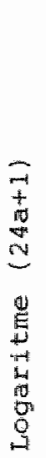 & 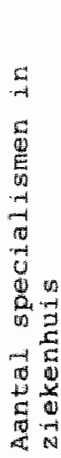 \\
\hline 泾" & $\underset{x \rightarrow c}{\infty}$ & ind & in & 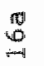 & 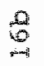 & & $\dot{r i m}_{\text {mant }}$ & $\infty$ & $\sum_{x=1}$ & $\dot{8}$ & $\vec{n}$ & $\stackrel{\sim}{\alpha}$ & & $\stackrel{n}{n}$ & $\frac{0}{m}$ & 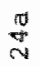 & $\frac{0}{d}$ & $\stackrel{*}{\infty}$ \\
\hline
\end{tabular}




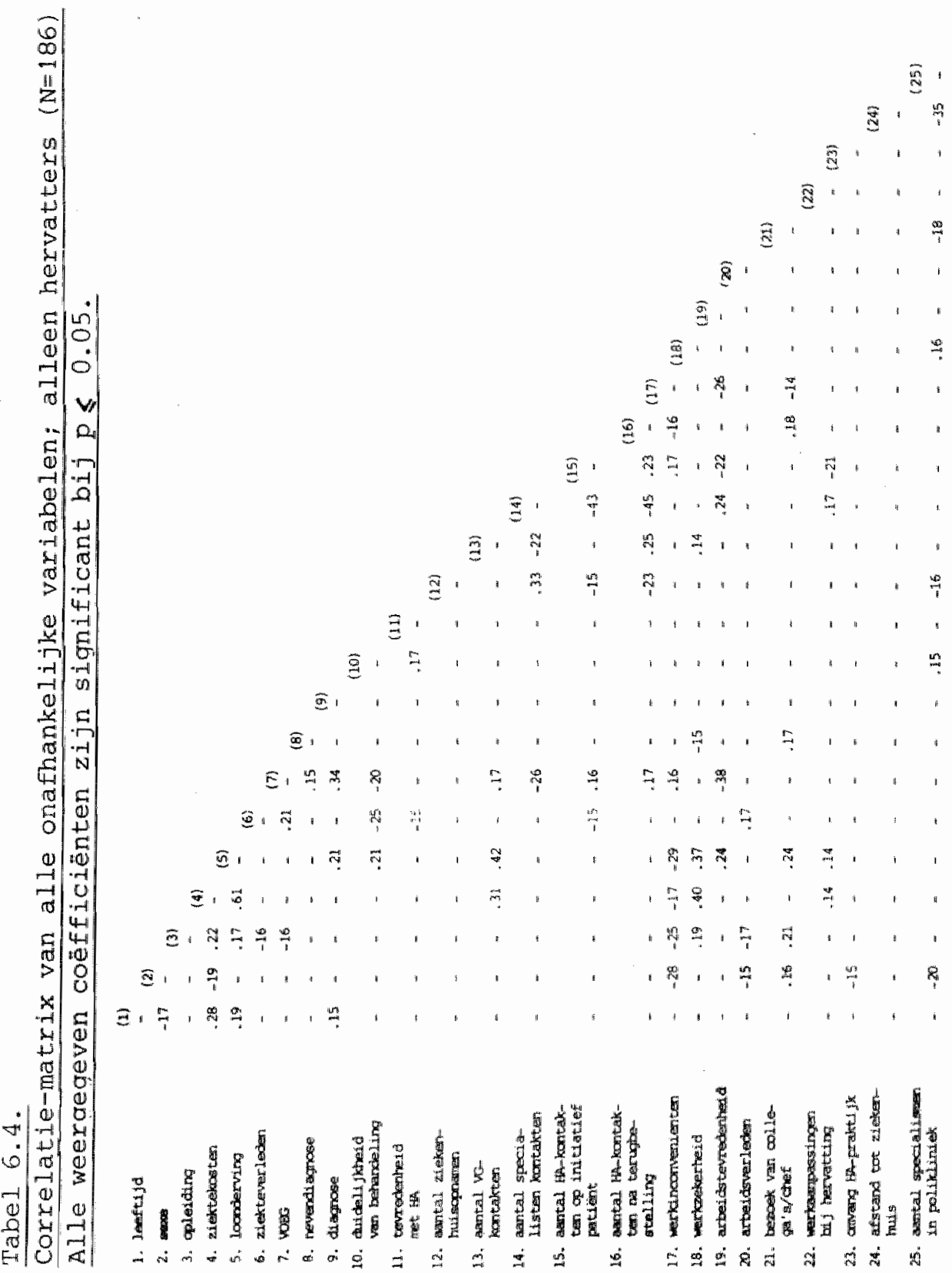


De auteur van dit proefschrift werd op 7 december 1954 geboren te Maastricht. Hij volgde een Middelbare Schoolopleiding aan het Henric van Veldeke-College te Mastricht, war hij in 1973 het eindexamen gymnasium- $\alpha$ behaalde. In dat jaar begon hij aan de Katholieke Universiteit van Nijmegen met de studie westerse sociologie. In september 1978 behalde hij het doctoraal examen, met als hoofdvak sociologie van arbeid \& organisatie, a a.s bijvakken economie en methoden \& technieken van onderzoek.

Van october 1976 tot april 1978 was hij-op halftime basisals wetenschappeijjk assistent verbonden aan het Instituut voor Toegepaste Sociologie te Nijmegen (sectie Arbeid en Bedrijf). Van october 1978 tot juli 1979 was hij werkzaam als onderzoeker op de afdeling "Statistiek \& Onderzoek" van het hoofdkantoor van het GAK, te Amsterdem. Van 1 augustus 1979 tot 1 augustus 1983 was $h i j$ als wetenschappelijk ambtenaar werkzaam bij de capaciteitsgroep Medische Sociologie van de Rijksuniversiteit Limburg. In die periode werkte hij aan het $z$-Limburgs ziekteverzuimproject. Vanaf 1 augustus $j \cdot 1$. is hij verbonden aan de nieuwe studierichting Economie van de Rijksuniversiteit Limburg, in de functie van wetenschappelijk medewerker. 